\title{
Fern and lycophyte flora of Acre state, Brazil
}

\author{
Jefferson Prado ${ }^{I^{*}}$, Regina Yoshie Hirai ${ }^{1} \&$ Robbin Craig Moran ${ }^{2}$ \\ ${ }^{1}$ Instituto de Botânica, Herbário, C.P. 68041, CEP 04045-972, São Paulo, SP, Brazil \\ ${ }^{2}$ The New York Botanical Garden, Herbarium, 10458-5126, Bronx, NY, USA \\ *Corresponding author: Jefferson Prado,e-mail: jprado.01@uol.com.br
}

PRADO, J., HIRAI, R., MORAN, R. C. Fern and lycophyte flora of Acre state, Brazil. Biota Neotropica. 17(4): e20170369. http://dx.doi.org/10.1590/1676-0611-BN-2017-0369

\begin{abstract}
This paper provides keys, illustrations, short descriptions, and voucher specimen citations for the ferns and lycophytes of Acre, Brazil. We recognize a total of 212 species in 66 genera and 28 families. Of these, the lycophytes are represented by 14 species, 4 genera, and 2 families, and the ferns by 8 varieties, 1 subspecies, 198 species, 62 genera, and 26 families. The total represents an increase of 22 species and two varieties compared to a checklist published in 2009. The six most species-rich genera are Adiantum (21 spp.), Asplenium (14), Selaginella (12), Trichomanes (11), Lindsaea, and Microgramma ( 9 each). None of the species treated here are endemic to Acre. A new combination is made for Meniscium chrysodioides Fée var. goyazense.
\end{abstract}

Keywords: Amazonia, Diversity, Floristics, Pteridophytes, Taxonomy

\section{Flora de samambaias e licófitas do estado do Acre, Brasil}

Resumo: Este trabalho fornece chaves, ilustrações, descrições curtas e citações de material examinado para as samambaias e licófitas do Acre, Brasil. Um total de 212 espécies, 66 gêneros e 28 famílias é reconhecido. Dentre estes, as licófitas constituem 14 espécies, 4 gêneros e 2 famílias e as samambaias 8 variedades, 1 subespécie, 198 espécies, 62 gêneros e 26 famílias. O total representa um aumento de 22 espécies e duas variedades comparado ao checklist publicado em 2009. Os seis gêneros mais ricos são Adiantum (21 spp.), Asplenium (14), Selaginella (12), Trichomanes (11), Lindsaea e Microgramma (9 cada). Nenhuma das espécies tratadas aqui é endêmica. Uma combinação nova é feita para Meniscium chrysodioides Fée var. goyazense.

Palavras-chave: Amazonia, Diversidade, Florística, Pteridófitas, Taxonomia

\section{Introduction}

Acre State, hereafter referred to as "Acre," is located in the southwestern Amazonia $\left(7^{\circ} 01^{\prime}-11^{\circ} 19^{\prime} \mathrm{S}\right.$ and $\left.66^{\circ} 47^{\prime}-74^{\circ} 03^{\prime} \mathrm{W}\right)$. It covers about $153,149 \mathrm{~km}^{2}$ and contains great variation in topography, soils, and climates. This in turn promotes a diversity of vegetation types, floristic affinities, and life forms. The state is part of the western Amazonia lowlands, with elevations ranging from 110-750 m (Cavalcante 2010). Physiographically, it can be conveniently divided into two regions. The first is the southeastern region drained by basin of the Purus River and by the Rivers Acre/Purus. The region exhibits a pronounced dry season from June to August. As a result, several species are shared with Central Brazil and with other extra-Amazonian vegetation types that also exhibit a pronounced dry season (Prado \& Gibbs 1993). The second region is northwestern Acre, drained by the Juruá River. This area is continuously wet, lacking a distinct dry season. Along its border with Peru are the mountainous Moa Range and Divisor Range, locally called the Serra do Moa and Serra do Divisor, respectively.

As outlined by Prado \& Moran (2009), the first expeditions to Acre and the Brazilian Amazon took place in 1900-1901 when Ernest Heinrich Georg Ule, a German botanist, collected along the rivers Tejo and Juruá-Mirim. Locally, this area is called Região do Alto Rio Juruá.
In 1911-1912, Ule conducted a second expedition in the region of the Acre River. The first Brazilian botanist to explore Acre was João Geraldo Kuhlmann, who travelled with Marechal Rondon through Amazonia in 1923. Later, in 1933, Boris Alexander Krukoff collected especially around the Macauã River, in the Basin of Purus River. During the 1960s and 1970s, several botanists collected in Acre, the most prominent being João Murça Pires, Ghillean T. Prance, Enrique Forero, Paul J. Maas, and Paulo G. Windisch. During the 1970s, other botanists, such as Luis Coêlho, Cid Ferreira, Bruce Nelson, and Thomas Croat, collected in Acre for the Project RADAMBRASIL. They were among the members of three expeditions to Acre (Silveira 2003).

In 1979 the Herbarium of the Federal University of Acre (UFACPZ) was established in the city of Rio Branco. Its goal was to develop a reference collection for the state. In 1990 the Herbarium signed an international agreement of cooperation with The New York Botanical Garden (NY) to promote studies of the Acre flora. Since the herbarium's inception, botanists such as Douglas Daly (NY), Marcos Silveira (UFAC), and others from many institutions have greatly increased the number of collections from Acre. According to Daly (personal communication), at the beginning of the project "Floristics and Economic Botany of Acre, Brazil," UFACPZ had about 2,000 specimens. It now has more than 30,000 , including non-vascular and vascular plants. The provisional 
acronym of this herbarium was "HPZ," and it was used in the checklist of ferns and lycophytes published by Prado \& Moran (2009). The official, accepted acronym used now is UFACPZ.

The collections that have accumulated over the years at UFACPZ provided the basis for the first comprehensive checklist of ferns and lycophytes of Acre (Prado \& Moran 2009). That checklist documented 24 families, 60 genera, 178 species, and five varieties. The goal of the present paper is to update the floristic account by Prado \& Moran (2009), include new species found since 2009, and provide a means of identification, including illustrations and keys to the genera and species.

\section{Materials and Methods}

This Flora is arranged according to the most recent classification for ferns and lycophytes (PPG I 2016), which recognizes only monophyletic groups. For ease of reference, the families are arranged alphabetically, as are the genera and species within them. The number of genera within a family, and species within a genus are given in the treatments below, and these numbers generally correspond to those found in PPG I (2016). Author abbreviations follow Pichi Sermolli (1996). For brevity, synonyms are omitted, except the basionym of the accepted name.

The first author of this Flora did fieldwork in several municipalities in Acre, during three weeks in October 2001, but most of the information gathered for this flora is based on herbarium studies. The main herbaria studied were UFACPZ, NY, RB, and SP. However, some specimens were received on loan from $\mathrm{BHCB}$, and some specimens were studied at $\mathrm{CEN}$, HB, HRCB, INPA, K, MG, MO, and UC.

In the species treatments below, all material cited is from Acre. For each species, the specimens are cited in alphabetical order by municipality and collector's surname. For each collector the numbers of collection were cited in ascending order.

Nearly all the illustrations were based on specimens collected in Acre (Figures 1-57). For some taxa we had to use additional material from outside Acre to prepare the drawings (e.g., Phlegmariurus dichotomus (Jacq.) W.H. Wagner), and in such instances, its non-Acre locality is cited in the figure caption. Whenever possible, each illustration groups species of the same genus or genera of the same family.

\section{Results}

Acre harbors a total fern and lycophyte flora consisting of 28 families, 66 genera, 212 species, 1 subspecies, and 8 varieties. Of these, the ferns constitute 26 families, 62 genera, 198 species, 1 subspecies, and 8 varieties; the lycophytes constitute 2 families, 4 genera, and 14 species. The six most species-rich genera were: Adiantum (21 spp.), Asplenium (14), Selaginella (12), Trichomanes (11), Lindsaea (9), and Microgramma (9). We did not find any endemic species to the state; however, four apparently undescribed species occur: two Steiropteris (might be endemics), one Lindsaea, and one Arachniodes, but more study is needed.

Although Acre does not have endemic species, along its border with Peru there are two mountainous areas, the Moa Range and Divisor Range. These areas shelter two Andean fern species not found elsewhere in Acre: Cyathea bipinnatifida (Baker) Domin (Cyatheaceae) and Pteris haenkeana C. Presl (Pteridaceae).

\section{LYCOPHYTES}

Characterized by leaves simple, entire, sessile, and single-veined, called microphylls. The sporangia are borne at leaf (sporophylls) bases on the adaxial surface, unlike ferns where the sporangia are borne abaxially or (more rarely) marginally. The sporophylls are similar to the other leaves or else modified and aggregated to form spikes called strobili. The Lycophytes belong to the Class Lycopodiopsida.
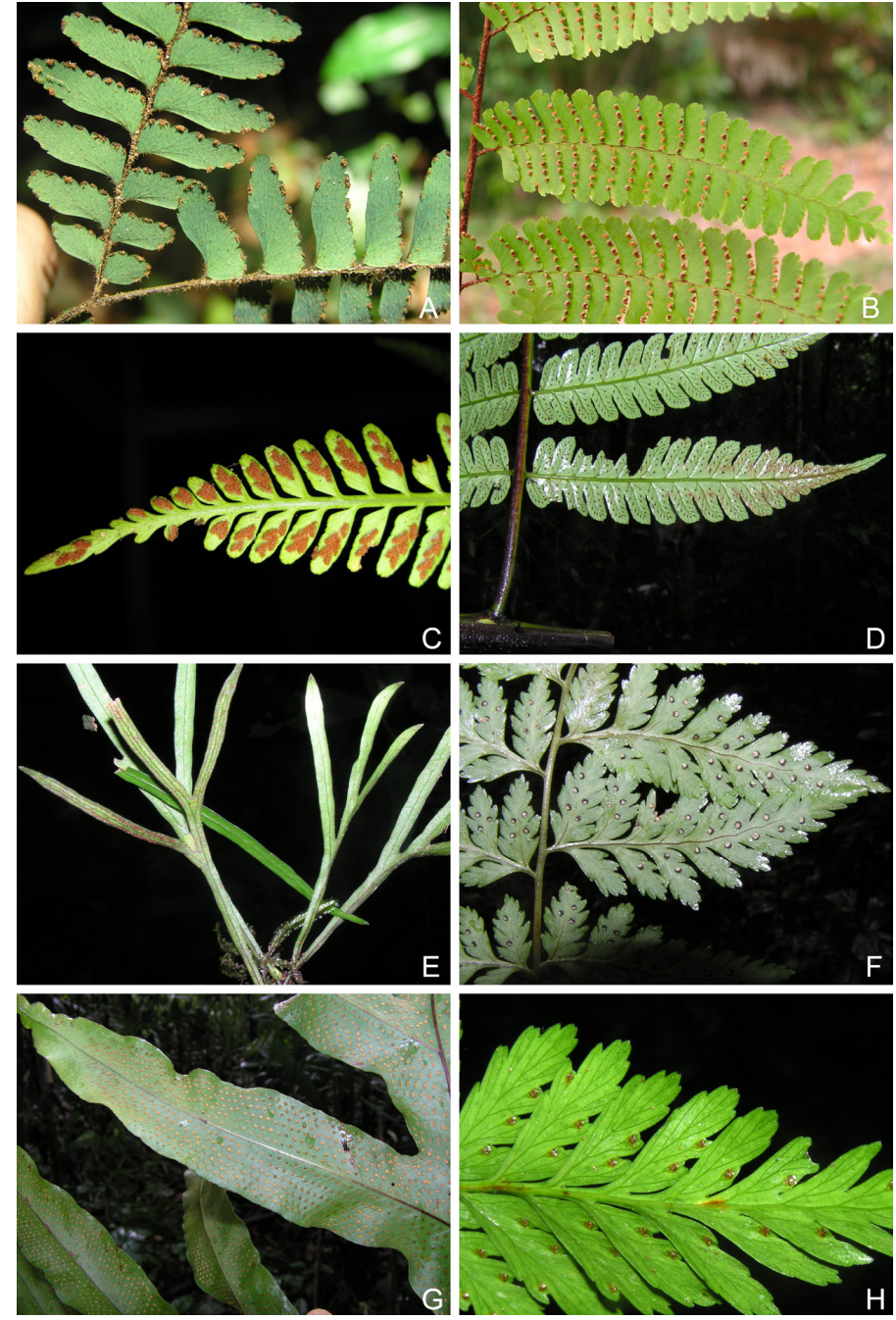

Figure 1. A. Adiantum humile. B. Adiantum pectinatum. C. Asplenium auritum D. Cyathea pungens. E. Pleopeltis desvauxii. F. Parapolystichum effusum var. divergens. G. Phlebodium decumanum. H. Saccoloma inaequale (all photos by D.C. Daly).

In Acre, lycophytes are represented by two families: Lycopodiaceae and Selaginellaceae. The Lycopodiaceae in Acre are comprised of Phlegmariurus and Palhinhaea, with one species each. Selaginella, with 12 species, is the largest genus of lycophytes in Acre.

Cosmopolitan; 3 orders, 3 families, 18 genera, ca. 1,338 species. In Acre, 2 orders, 2 families, 3 genera, and 14 species.

1. Ultimate branchlets terete; leaves many-rowed, radially arranged around branchlets; strobili terete; plants homosporous

LYCOPODIACEAE

1. Ultimate branchlets complanate; leaves 4-rowed, with 2 medial rows that point apically and 2 lateral rows that point outward or laterally; strobili quadrangular; plants heterosporous

SELAGINELLACEAE

\section{LYCOPODIACEAE}

This family belongs to the Lycopodiales, and PPG I (2016) accepted three subfamilies. Acre harbors two of the subfamilies: Lycopodielloideae, represented by Palhinhaea Franco \& Vasc., and Huperzioideae, represented by Phlegmariurus Holub. 
Cosmopolitan; 16 genera, ca. 388 species. In Acre, 2 genera, 2 species.

1. Plants terrestrial, anisodichotomously branched with long horizontal runners; leaves forming pendant strobili Palhinhaea

1. Plants epiphytic, isodichotomously branched, without horizontal runners; leaves not forming strobili

Phlegmariurus

Palhinhaea Franco \& Vasc., Bol. Soc. Brot., sér. 2, 41: 24. 1967.

Characterized by main horizontal stems creeping, superficial, indeterminate, branching dichotomously in the horizontal plane, also branching in the vertical plane to give rise to single dorsal rank of erect determinate branching systems, these tree-like, their stem surfaces often puberulent, the hairs ca. $0.1-0.3 \mathrm{~mm}$ long, unicellular; ultimate branchlets terete (not flattened), isophyllous, with leaves polystichous, not in distinct ranks, lacking hyaline hairlike apices; gemmiferous branchlets and gemmae absent; strobili sessile, nodding or pendant; sporophylls peltate, with a decurrent medial wing, stramineous at time of sporangial dehiscence; sporangia almost completely enclosed in cavities formed by the cortex of the strobilus and covered by the basal membranes of adjacent sporophylls, anisovalvate, reniform, the epidermal cells with nodular thickenings; spores rugate to nearly smooth, the sides convex at the equator.

Pantropical; ca. 25 species, 1 in Acre.

Palhinhaea cernua (L.) Vasc. \& Franco, Bol. Soc. Brot, sér. 2, 41: 25. 1967. Lycopodium cernuum L., Sp. Pl. 2: 1103. 1753.

Figures: 2A, B

Habit/Habitat: Herb; terrestrial on sandy and clay soils in open places.

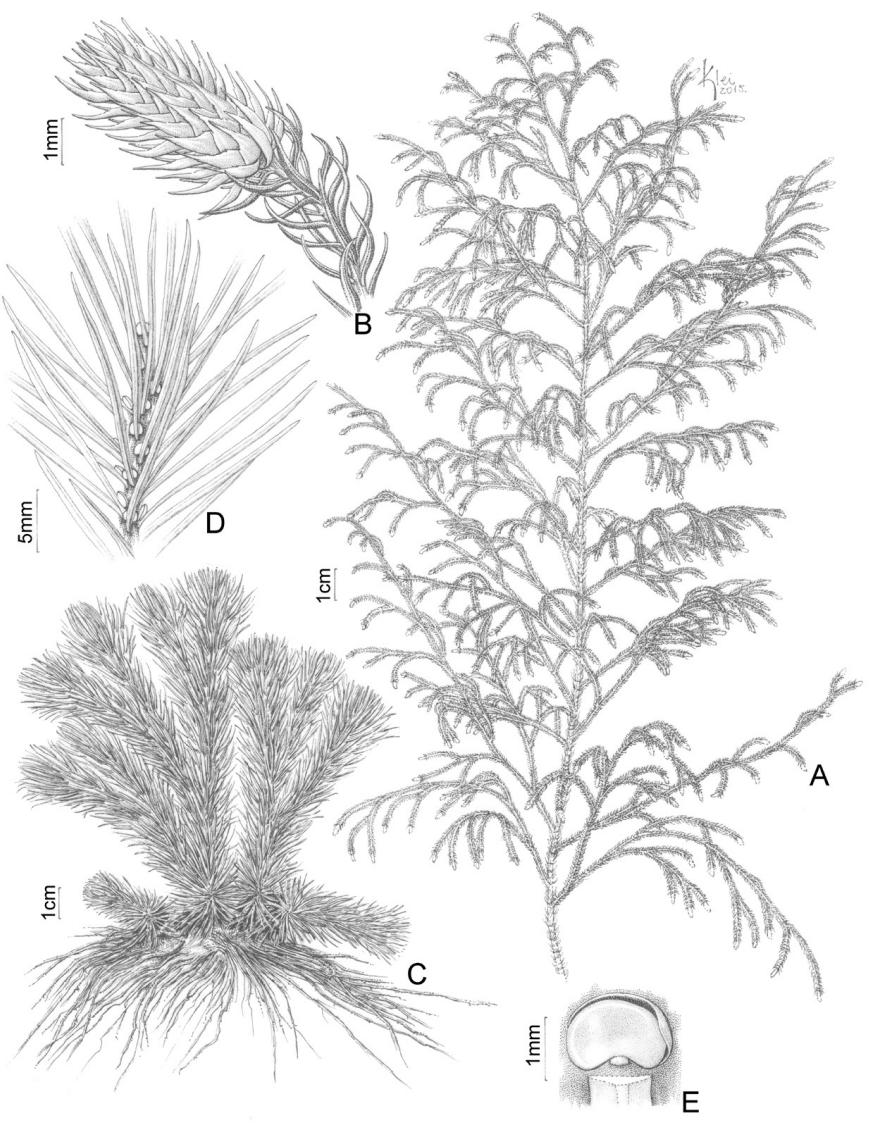

Figure 2. A, B. Palhinhaea cernua (Prado et al. 1191, SP). A. Habit. B. Strobile. C-E. Phlegmariurus dichotomus (from Brazil, Roraima, Ilha de Maracá, Milliken et al. 84 , NY). C. Habit. D. Apex of a fertile branch. E. Sporangium.
Material examined: Cruzeiro do Sul, D.C. Daly et al. 10599 (NY), D.C. Daly et al. 10683 (NY), P. Delprete et al. 8063 (NY), L.R. Marinho 64 (NY), L.R. Marinho 212 (NY), J. Prado et al. 1160 (SP, UFACPZ), J. Prado et al. 1191 (SP, UFACPZ), J. Prado et al. 1331 (UFACPZ), G.T. Prance et al. 12525 (MG, NY), A. Rosas Jr. et al. 313 (NY).

World Distribution: Pantropical.

Terrestrial, forming large populations by elongate horizontal runners. The erect shoots are $0.5-1.0 \mathrm{~m}$ tall, highly branched, and resemble a small Pinus. The strobili are pendant at the tips of the ultimate branches. The leaves are small and narrow (ca. $3.5-5 \times 0.2 \mathrm{~mm}$ ).

Phlegmariurus (Herter) Holub, Preslia 36(1): 17, 21. 1964. Lycopodium sect. Phlegmariurus Herter, Bot. Jahrb. Syst. 43(1-2, Beibl. 98): 30. 1090.

Characterized by stems isodichotomously branched, the branches all similar, or in some terrestrial species slightly differentiated into prostrate versus erect aerial branches; roots descending through the cortex to the stem bases and emerging in one basal tuft; leaves homophyllous or heterophyllous, entire or (less rarely) minutely toothed; gemmae and gemmiphores absent; strobili absent, the sporangia produced in zones along the shoots; sporophylls either similar to the trophophylls or more reduced and appressed, remaining green after the sporangia dehisce; sporangia isovalvate; sporophylls similar to the trophophylls, attached at the base (not peltate), remaining green after sporangial dehiscence; spores foveolate on distal face, smooth on proximal, in polar view rounded with convex sides and angles acute.

Pantropical; ca. 250 species, 1 in Acre.

Phlegmariurus dichotomus (Jacq.) W.H. Wagner, Novon 3(3): 305. 1993. Lycopodium dichotomum Jacq., Enum. Stirp. Vindob. 314. 1762.

Figures: $2 \mathrm{C}-\mathrm{E}$

Habit/Habitat: Herb; epiphyte in forest on terra firme.

Material examined: Without locality, M. Silveira s.n. (UFACPZ).

World Distribution: Florida, Mexico, Antilles, Mesoamerica, and N South America to Bolivia.

Epiphytic; distinct by microphylls $1.5-2.0 \mathrm{~cm}$ long, entire, and by the leaves not differentiated as distinct strobili on the tips of the branches.

\section{SELAGINELLACEAE}

Characterized by flattened branches dichotomously divided, presence of microphylls disposed in two dorsal rows and two lateral rows. Also, by the presence of rhizophores that can be formed adaxially or abaxially on the branch dichotomies. The rhizophores are greatly elongate and do not branch until touching the ground. Selaginellaceae belongs to the Selaginellales.

A large and diverse family. Recently, Valdespino et al. (2015) and Valdespino (2015a, 2015b) described many new species of Selaginella. According to Valdespino (2015b), 86 species of the genus occur in Brazil.

Cosmopolitan, mainly in tropical and subtropical areas (Jermy 1990, Valdespino 1993, Mickel et al. 2004); 1 genus, ca. 700 species. In Acre, 12 species.

Selaginella P. Beauv., Mag. Encycl. 9(5): 478. 1804, nom. cons. Same characters as the family.

1. Main branches articulate (i.e., with a slight swelling or dark line just below each bifurcation of the branches)

2. Branches pubescent S. exaltata

2. Branches glabrous

3. Axillary leaves without auricles or with two inconspicuous auricles . S. parkeri

3. Axillary leaves with conspicuous auricles

4. Axillary and lateral leaves with ciliate margins .... S. sulcata

4. Axillary and lateral leaves sparsely denticulate 
5. Axillary and lateral leaves with two very short auricles .. S. asperula

5. Axillary and lateral leaves with two conspicuous auricles

S. conduplicata

1. Main branches not articulate

6. Main erect branches reddish S. haematodes

6. Main erect branches greenish or stramineous

7. Main stems compressed at base

S. amazonica

7. Main stems terete at base

8. Apex of the main branch flagelliform S. flagellata

8. Apex of the main branch not flagelliform

9. Medial leaves long-aristate or aristate

10. Dorsal leaves round with apex long-aristate (almost twice the length of the leaf)

S. flexuosa

10. Dorsal leaves elliptic, asymmetric and with apex aristate S. palmiformis

9. Medial leaves acuminate

11. Lateral leaves acroscopically auriculate S. lechleri

11. Lateral leaves not auriculate S. anceps

Selaginella amazonica Spring, F1. Bras. 1(2): 124. 1840.

Habit/Habitat: Herb; terrestrial on terra firme.

Material examined: Sena Madureira, D.C. Daly et al. 8199 (NY).

World Distribution: N South America.

Characterized by main stems compressed at base and leaves denticulate, without auricles.

Selaginella anceps (C. Presl) C. Presl, Abh. Konigl. Bohm. Ges. Wiss., ser. 5, 3: 581. 1845. Lycopodium anceps C. Presl, Reliq. Haenk. 1(1): 80.1825 .

Figures: $3 \mathrm{~A}-\mathrm{C}$

Habit/Habitat: Herb; terrestrial in forest on terra firme.

Material examined: Porto Walter, T.B. Croat 85151 (NY); Sena Madureira, D.C. Daly et al. 7891 (NY), D.C. Daly et al. 8139 (NY).

World Distribution: Mesoamerica and N South America to Bolivia.

Characterized by the non-auriculate axillary and lateral leaves with ciliate margins at base, and dorsal leaves acuminate, each with two ciliate auricles.

Selaginella asperula Spring, F1. Bras. 1(2): 127. 1840.

Figures: 3D-F

Habit/Habitat: Herb; terrestrial in Campina forest, on sandy soils.

Material examined: Cruzeiro do Sul, T.B. Croat \& A. Rosas Jr. 62643 (NY, UFACPZ), D.C. Daly et al. 10646 (NY), J. Prado et al. 1155 (SP, UFACPZ), J. Prado et al. 1156 (SP, UFACPZ), J. Prado et al. 1169 (SP, UFACPZ), J. Prado et al. 1185 (SP, UFACPZ), J. Prado et al. 1192 (SP, UFACPZ), J. Prado et al. 1193 (SP, UFACPZ), J. Prado et al. 1391 (SP, UFACPZ), G.T. Prance et al. 12643 (NY); Porto Valter, D.C. Daly et al. 7573 (NY, UFACPZ).

World Distribution: N South America to Bolivia.

Characterized by articulate branches, axillary and lateral leaves each with two short auricles, sparsely denticulate at base and serrate distally, dorsal leaves short-aristate, auriculate, peltate. The margins of leaves are light green.

Selaginella conduplicata Spring, Fl. Bras. 1(2): 129. 1840.
Habit/Habitat: Herb; terrestrial growing in terra firme forest, on sandy or clay soils.

Material examined: Marechal Thaumaturgo, D.C. Daly et al. 7381 (NY).

World Distribution: N South America to Peru.

Characterized by articulate branches, axillary leaves with two curved auricles, lateral leaves each with the acroscopic auricle longer than the basiscopic one, and dorsal leaves symmetric with acuminate apices. All leaves on the plant are sparsely denticulate.

Selaginella exaltata (Kunze) Spring, Bull. Acad. Roy. Sci. Bruxelles 10(1): 234. 1843. Lycopodium exaltatum Kunze, Linnaea 9: 8. 1834[1835].

Figures: 3G-I

Habit/Habitat: Herb; terrestrial in forest on terra firme and várzea forest.

Material examined: Bujari, W.A. Anderson 12124 (NY); Brasiléia, D.C. Daly et al. 6820 (NY, UFACPZ); Cruzeiro do Sul, L.R. Marinho 258 (NY), J. Prado et al. 1289 (SP, UFACPZ); Mâncio Lima, J. Jangoux et al. 85-093 (MG, NY), G.T. Prance et al. 12157 (NY); Plácido de Castro, D.C. Daly et al. 6123 (NY, UFACPZ); Porto Valter, P.J.M. Maas et al. P12951 (MG, NY); Rio Branco, D.C. Daly et al. 6676 (NY, UFACPZ); Sena Madureira, B. Nelson et al. 527 (NY), G.T. Prance et al. 7626 (NY); Tarauacá, G.T. Prance et al. 7405 (NY); Xapuri, A.R.S. Oliveira et al. 198 (MG, NY); Without locality, E. Forero et al. 6305 (NY).

World Distribution: Mesoamerica and N South America to Bolivia.

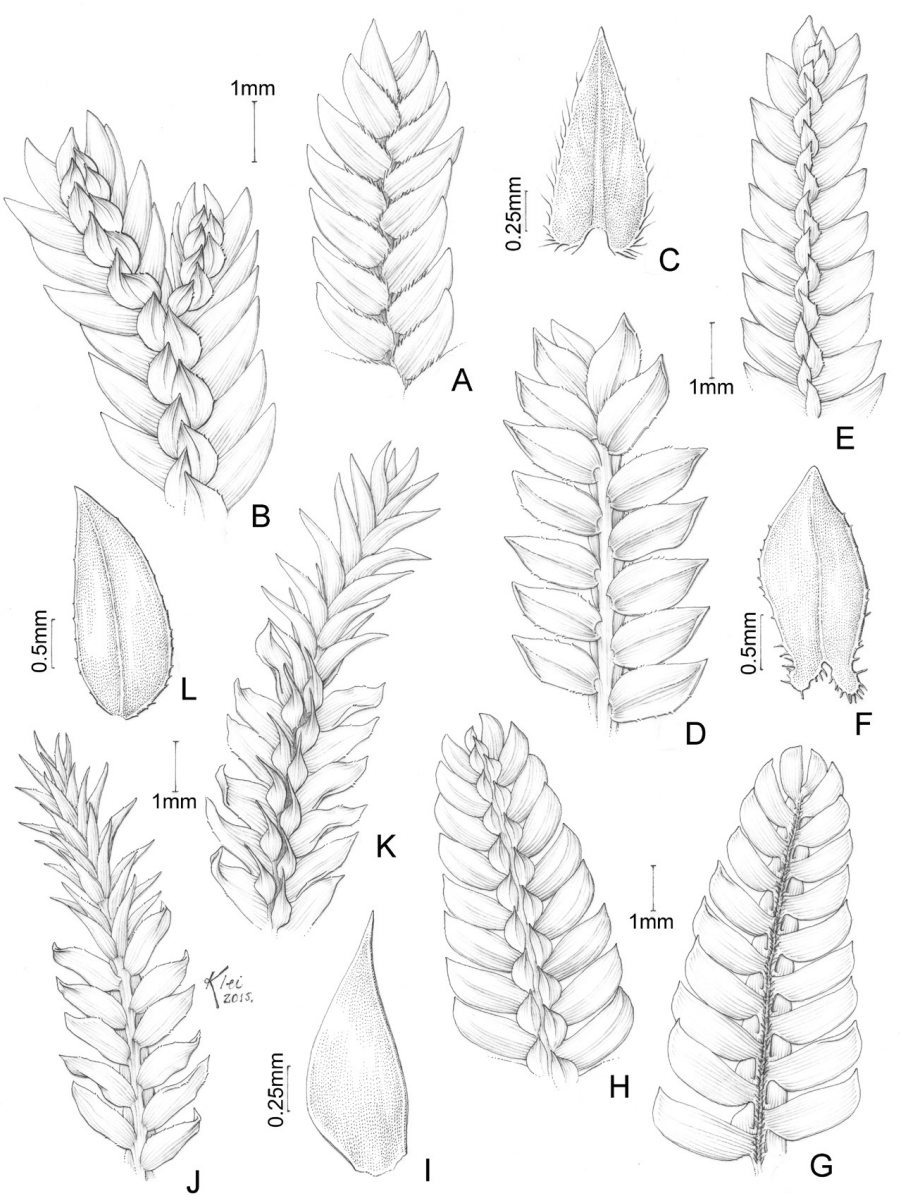

Figure 3. A-C. Selaginella anceps (Croat 85151, NY). A. Abaxial leaves. B. Adaxial leaves. C. Dorsal leaf. D-F. Selaginella asperula (Prado et al. 1391, SP). D. Abaxial leaves. E. Adaxial leaves. F. Axillary leaf. G-I. Selaginella exaltata (Prado et al. 1289, SP). G. Abaxial leaves. H. Adaxial leaves. I. Axillary leaf. J-L. Selaginella flagellata (Daly et al. 9479, NY). J. Abaxial leaves. K. Adaxial leaves. L. Axillary leaf. 
The largest species of Selaginella, often growing over the surrounding vegetation, using it for support. Characterized by articulate, pubescent branches, axillary leaves asymmetric, not auriculate, entire, lateral leaves not auriculate, appressed to the stem, entire, and dorsal leaves asymmetric, aristate, basifixed. The basal megaspore is so large that it pushes the strobilus to one side, making it appear crooked.

Selaginella flagellata Spring, Bull. Acad. Roy. Sci. Bruxelles 10(1): 228. 1843.

Figures: $3 \mathrm{~J}-\mathrm{L}$

Habit/Habitat: Herb; terrestrial in "Baixio", low terraces possibly flooded occasionally by overflowing streams.

Material examined: Bujari, D.C. Daly et al. 9479 (NY); Manoel Urbano, D.C. Daly et al. 11439 (NY); Marechal Taumaturgo, D.C. Daly et al. 7669 (NY).

World Distribution: Mexico, Mesoamerica, and tropical South America.

Characterized by flagelliform main axes, denticulate and non-auriculate axillary and lateral leaves, and dorsal leaves denticulate, aristate, and not auriculate. All leaves have hyaline margins.

Selaginella flexuosa Spring, Flora 21: 197. 1838.

Habit/Habitat: Herb.; growing in forest on terra firme, on wet clay soils.

Material examined: Mâncio Lima, P. Fiaschi et al. 3390 (NY).

World Distribution: Mexico, Mesoamerica, and N South America to Bolivia.

Characterized by rugose leaves, the dorsal ones round, denticulate, and long-aristate (the aristae almost twice the length of the leaf). Axillary and lateral leaves denticulate, not auriculate.

Selaginella haematodes (Kunze) Spring, Fl. Bras. 1(2): 126. 1840. Lycopodium haematodes Kunze, Linnaea 9: 9. 1834[1835].

Figures: $4 \mathrm{~A}-\mathrm{C}$

Habit/Habitat: Herb; terrestrial in open forest on steep hilly terrain.

Material examined: Santa Rosa, D.C. Daly et al. 11141 (NY).

World Distribution: Mesoamerica and N South America to Bolivia.

Characterized by main erect stem reddish, sometimes also with reddish leaves. The axillary and lateral leaves are not auriculate, appressed to the stem, with serrulate margins, and often with whitish idioblasts (visible as fine streaks) running obliquely from the costae to the margins. The dorsal leaves are sparsely serrulate, long-acuminate to aristate, and not auriculate.

Selaginella lechleri Hieron., Nat. Pflanzenfam. 1(4): 683. 1901.

Figures: 4D-F

Habit/Habitat: Herb; terrestrial in forest on terra firme.

Material examined: Mâncio Lima, D.C. Daly et al. 8879 (NY).

World Distribution: Mesoamerica and N South America.

Characterized by the axillary leaves ciliate basally, not auriculate, lateral leaves acroscopically auriculate, the auricles ciliate, and dorsal leaves ciliate, acuminate, and not auriculate.

Selaginella palmiformis Alston ex Crabbe \& Jermy, Amer. Fern J. 63(3): 141. 1973.

Habit/Habitat: Herb; terrestrial in forest on terra firme near stream margins.

Material examined: Santa Lucia, J. Pruski et al. 3466 (NY).

World Distribution: N South America.

Characterized by the axillary leaves with truncate base, not auriculate, and margins denticulate. Dorsal leaves elliptic, asymmetric, with aristate apex and margins denticulate. Branches not articulate.

Selaginella parkeri (Hook. \& Grev.) Spring, Bull. Acad. Roy. Sci. Bruxelles 10: 146. 1843. Lycopodium parkeri Hook. \& Grev., Bot. Misc. 2: 388.1843.

Figures: 4G-I
Habit/Habitat: Herb; terrestrial in forest on terra firme near stream margins.

Material examined: Cruzeiro do Sul, J. Prado et al. 1184 (SP, UFACPZ), J. Prado et al. 1319 (SP, UFACPZ), G.T. Prance et al. 12305 (NY); Mâncio Lima, G.T. Prance et al. 12200 (NY), M. Silveira et al. 1273 (NY);

Rodrigues Alves, J. Prado et al. 1362 (SP, UFACPZ).

World Distribution: N South America.

Characterized by articulate branches, the axillary leaves widest at or near the middle, without auricles or with two inconspicuous ones, denticulate, lateral leaves auriculate, with two denticulate auricles of almost the same size, and dorsal leaves long-acuminate, peltate, auriculate, and serrate.

Selaginella sulcata (Desv. ex Poir.) Spring ex Mart., Flora 20(2): 126. 1837. Lycopodium sulcatum Desv. ex Poir., Encycl., Suppl. 3: 549. 1814.

Figures: 4J-L

Habit/Habitat: Herb; terrestrial in forest on terra firme, on poorly drained soils, undulating terrain dissected by numerous streams.

Material examined: Cruzeiro do Sul, D.C. Daly et al. 7381 (NY, SP); Manoel Urbano, D.C. Daly et al. 9134 (NY); Marechal Thaumaturgo, D.C. Daly et al. 10585 (NY, SP); Sena Madureira, L. de Lima et al. 540 (NY, UFACPZ); Xapuri, C. Figueiredo 214 (NY).

World Distribution: Tropical South America.

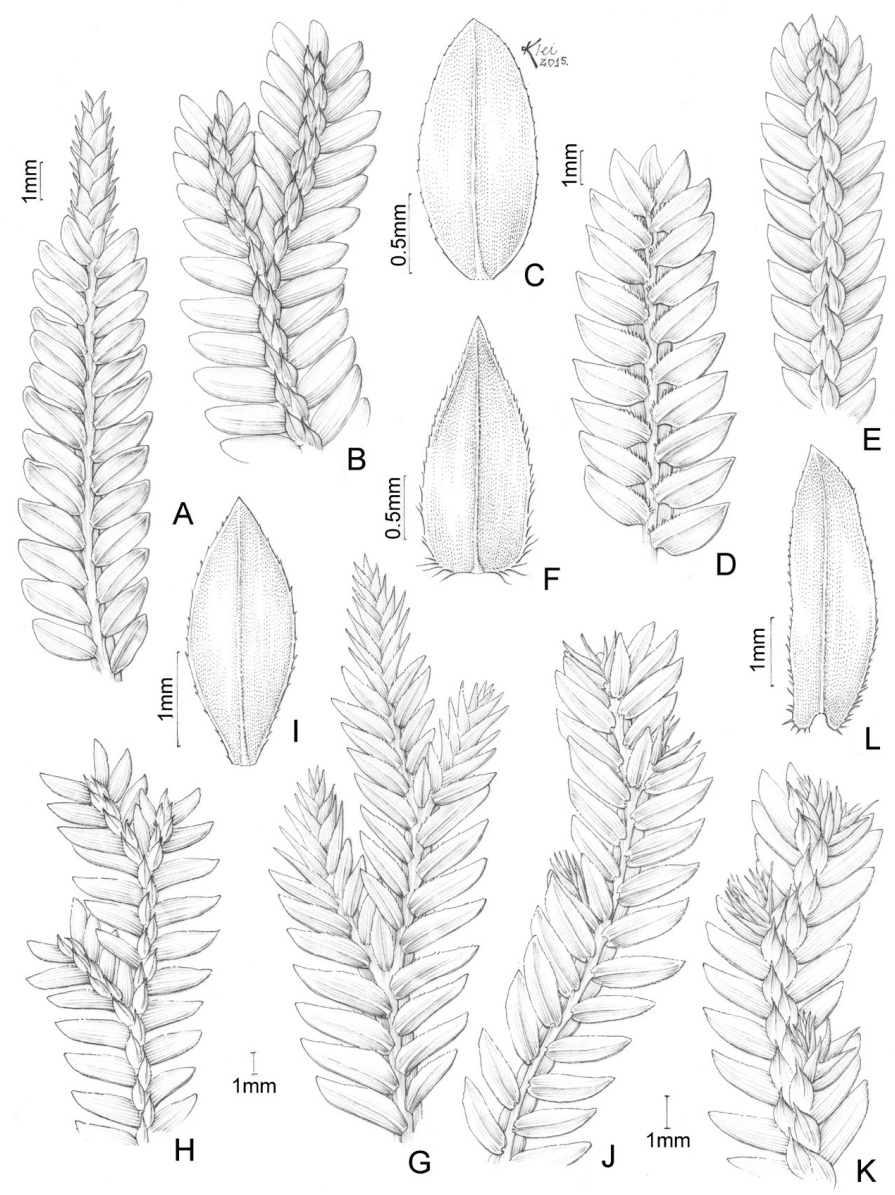

Figure 4. A-C. Selaginella haematodes (Daly et al. 11141, NY). A. Abaxial leaves. B. Adaxial leaves. C. Axillary leaf. D-F. Selaginella lechleri (Daly et al. 8879 , NY). D. Abaxial leaves. E. Adaxial leaves. F. Dorsal leaf. G-I. Selaginella parkeri (Prado et al. 1184, SP). G. Abaxial leaves. H. Adaxial leaves. I. Axillary leaf. J-L. Selaginella sulcata (Lima et al. 540, NY). J. Abaxial leaves. K. Adaxial leaves. L. Axillary leaf. 
Characterized by the axillary leaves auriculate and basally ciliate, lateral leaves auriculate, the auricles ciliate, the acroscopic auricle longer than the basiscopic one, and dorsal leaves aristate, peltate.

\section{FERNS}

Generally characterized by the presence of fiddleheads, two lateral light-colored areophore lines on either side of the petioles, and sporangia borne on the lower surface of the leaves (marginal in Trichomanes and Hymenophyllum). The leaves of ferns are believed to have had a different evolutionary origin than those of lycophytes. For that reason, they are called megaphylls (euphylls), versus microphylls (lycophylls) for lycophytes. The sporangia are clustered on the abaxial surface of the laminae, not single on the adaxial surface as in the lycophytes.

PPG I (2016) treated these plants in one class (Polypodiopsida) and four subclasses (Equisetidae, Ophioglossidae, Marattiidae, Polypodiidae),

Cosmopolitan; 11 orders, 48 families, and ca. 10,578 species. In Acre, 26 families, 62 genera, 198 species, 1 subspecies, and 8 varieties.

1. Sporangia connate laterally into synangia

2. Stems green, aerial, isodichotomously branched; leaves squamiform, ca. $1 \mathrm{~mm}$ long

PSILOTACEAE

2. Stems non-green, subterranean, unbranched; leaves foliose, more than $50 \mathrm{~cm}$ long

MARATTIACEAE

1. Sporangia free, distinct

3. Laminae 1-cell thick between the veins

HYMENOPHYLLACEAE

3. Laminae several cells thick between the veins

4. Plants aquatic, floating

SALVINIACEAE

4. Plants terrestrial, hemi-epiphytic or epiphytic

5. Pinnae dichotomously branched with a bud in the fork, the segments pectinate GLEICHENIACEAE

5. Pinnae unbranched, or if so (Lygodium), the segments pinnately or palmately arranged

6. Plants arborescent

CYATHEACEAE

6. Plants herbaceous

7. Sporangia with a complete apical annulus

8. Plants twining LYGODIACEAE

8. Plants not twining

9. Laminae 1-pinnate or more dissected; veins anastomosing or free; sporangia borne distally on erect, elongate basal pinnae

ANEMIACEAE

9. Laminae entire to incised; veins free; sporangia borne in fingerlike marginal lobes of the lamina

SCHIZAEACEAE

7. Sporangia with vertical annulus interrupted at the stalk, or if complete, then obliquely oriented around the capsule (not apical) and bypassing the stalk

10. Rhizomes hairy

11. Rhizomes short-creeping, densely hairy; sori scattered near the costae ...... METAXYACEAE

11. Rhizomes long-creeping, sparsely hairy; sori marginal or submarginal

DENNSTAEDTIACEAE

10. Rhizomes scaly
12. Indusia opening toward the lamina margin

LINDSAEACEAE

12. Indusia (when present) opening toward the costa or segment apex

13. Petioles in cross section with omega-shaped vascular bundle

14. False indusia present; rhizomes creeping to decumbent; sori elongate to linear, paraphysate

PTERIDACEAE (Pteris)

14. False indusia absent; rhizomes erect; sori obconic, pocket-like, non-paraphysate SACCOLOMATACEAE

13. Petioles in cross section with 1 to many circular vascular bundles, or two elongate or strap-shaped ones

15. Spores tetrahedral-globose, trilete

PTERIDACEAE

15. Spores fabiform (bean-shaped), monolete

16. Petioles each with 2 strap-shaped vascular bundles

17. Sori round; leaves pubescent with acicular hairs, these sometimes short-forked apically

THELYPTERIDACEAE

17. Sori elongate to linear; leaves glabrous, or if pubescent, the hairs not lax, jointed, not acicular

18. Rhizome scales clathrate ..... ASPLENIACEAE

18. Rhizome scales non-clathrate

19. Pinnae opposite; veins free near costae but anastomosing toward pinna margins

HEMIDICTYACEAE

19. Pinnae alternate; veins either free or (more rarely) anastomosing throughout

20. Sori solitary, not paired back-to-back along the same vein; main lateral veins connected by cross veins

.... THELYPTERIDACEAE (Meniscium)

20. Sori (at least some) paired back-to-back along the same vein (diplazioid); main lateral veins not connected by cross veins

21. Submarginal connecting vein present; laminae coriaceous

DESMOPHLEBIACEAE

21. Submarginal connecting vein absent; laminae herbaceous to chartaceous

ATHYRIACEAE

16. Petioles each with 3 or more vascular bundles, the 2 adaxial ones larger than the ones in an arc below them

22. Sori linear and parallel to the midribs; leaves reddish when young

BLECHNACEAE

22. Sori round or acrostichoid; leaves green when young

23. Spores yellow or whitish

POLYPODIACEAE

23. Spores brown or black

24. Leaves 2-pinnate, each with a conform apical pinna, with a skunk-like odor when crushed; pinnules dimidiate

DIDYMOCHLAENACEAE

24. Leaves simple to 3-pinnate, each with tapered pinnatifid apices, without a skunk-like odor when crushed; pinnules (when present) non-dimidiate 
25. Pinna pairs 20-40; stolons present; rachis scales with pointed end oriented basiscopically; older leaves typically with a small fiddlehead at the tip

NEPHROLEPIDACEAE

25. Pinna pairs (when present) to 15 pairs; stolons absent; rachis scales (when present) with pointed end oriented acroscopically; older leaves without a small fiddlehead at the tip

26. Plants hemiepiphytic.... LOMARIOPSIDACEAE

26. Plants terrestrial or holoepiphytic

27. Rachises and costa adaxially rounded (not grooved), densely and evenly puberulent with hairs ca. $0.1 \mathrm{~mm}$ long, or if glabrous, rhizomes and petioles with odor of hydrogen cyanide when cut

TECTARIACEAE

27. Rachises and costa adaxially grooved, glabrous or if pubescent, the hairs longer than $0.1 \mathrm{~mm}$.

DRYOPTERIDACEAE

\section{ANEMIACEAE}

Characterized by 1-pinnate or more dissected laminae with basal pinnae long-stalked and erect, bearing sporangia distally. Petioles in cross-section each with a single circular vascular bundle. Belongs to the Schizaeales, an order characterized by a complete apical annulus. Brazil is its center of diversity, with 61 species (Mickel 2016).

Pantropical and subtropical, but predominantly Neotropical; 1 genus, 115 species. In Acre, 1 genus, 1 species.

Anemia Sw., Syn Fil. 6: 155. 1806, nom. cons.

Characters of the family.

Anemia phyllitidis (L.) Sw., Syn. Fil. 155. 1806. Osmunda phyllitidis L., Sp. Pl. 2: 1064. 1753.

Figures: $5 \mathrm{~A}, \mathrm{~B}$

Habit/Habitat: Herb; terrestrial on riverside vegetation and in terra firme forest.

Material examined: Assis Brasil, D.C. Daly et al. 9779 (NY, UFACPZ); Brasiléia, D.C. Daly et al. 9895 (NY, UFACPZ).

World Distribution: Mexico, Greater Antilles, except Puerto Rico, Mesoamerica, tropical and subtropical South America.

Characterized by hemidimorphic leaves, with the basal pinnae erect and bearing sporangia distally, and sterile pinnae with anastomosing veins.

\section{ASPLENIACEAE}

Characterized by the combination of clathrate rhizome scales and elongate or linear sori. Extremely variable as to leaf dissection, from simple to 4-pinnate. On large individuals, 2 vascular bundles may be observed in the petiole bases, as is typical for Eupolypods II (only 1 visible in small species). Other characters are stems dictyostelic, erect, decumbent, or creeping; leaves monomorphic, rarely subdimorphic with fertile leaves taller and more erect; veins free or netted, their tips hydathodous adaxially; sori usually oriented obliquely to the midrib; indusium present, attached along the vein on one side of the sorus; sporangia with vertical annulus interrupted by the stalk, the annulus cells typically $15-28$, the stalks with 1 row of cells.

Cosmopolitan; 2 genera, both in Acre.

1. Rhizomes erect or suberect; leaves polystichous, arranged in many rows radially around the rhizomes

Asplenium

1. Rhizomes creeping; leaves distichous, arranged in two rows on the dorso-lateral surface of the rhizomes

Hymenasplenium

Asplenium L., Sp. Pl. 2: 1078. 1753.

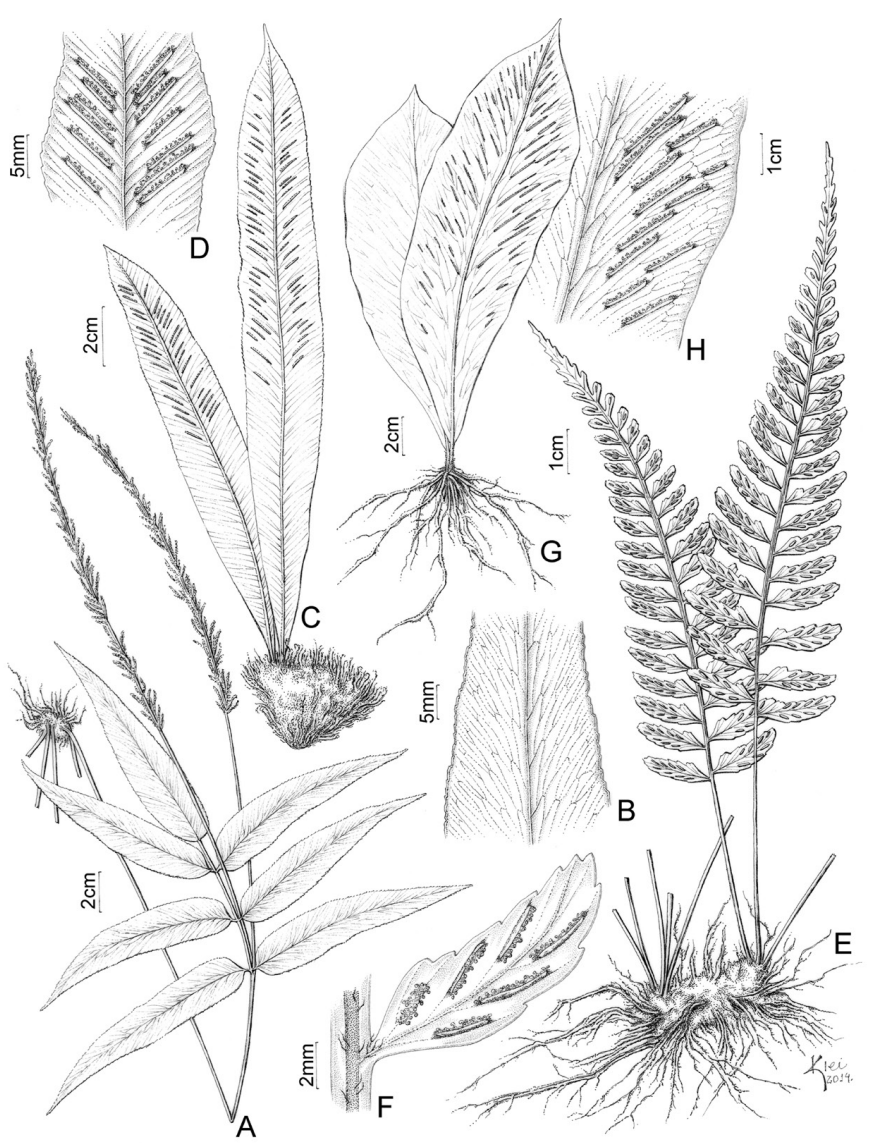

Figure 5. A, B. Anemia phyllitidis (Daly et al. 9779, NY). A. Habit. B. Venation of the sterile frond. C, D. Asplenium angustum (Daly et al. 8953, NY). C. Habit. D. Sori. E, F. Asplenium auritum (Prance et al. 11977, NY). E. Habit. F. Sori. G, H. Asplenium brasiliense (Michelangeli et al. 1383, NY). G. Habit. H. Sori.

Characterized by linear or elongate sori and clathrate rhizome scales. Quite variable in laminar dissection and shape. About half of the species are epiphytic, and the other half mostly terrestrial.

Cosmopolitan; ca. 700 species, 14 in Acre.

1. Leaves entire

2. Venation areolate.

A. brasiliense

2. Venation free

3. Laminae $1.5-2.5(-3.5) \mathrm{cm}$ wide; petioles absent or very short $(<1 \mathrm{~cm})$; sori medial on distal portion of the lamina

A. angustum

3. Laminae 3.5-6.5(-9.5) cm wide; petioles present $(<1 \mathrm{~cm})$; sori generally throughout the lamina

4. Petioles and rachises dark brown to black ......A. stuebelianum

4. Petioles and rachises greenish or light brown

5. Rachises and adjacent lamina with scales abaxially .... A. serratum

5. Rachises and adjacent lamina glabrous abaxially .... A. pearcei

1. Leaves 1- to 2-pinnate

6. Leaves 2-pinnate 
7. Laminae elliptic; proximal pinnules overlapping the rachis ...... A. pedicularifolium

7. Laminae deltate; proximal pinnules not overlapping the rachis A. cuneatum

6. Leaves 1-pinnate

8. Lamina apices conform (terminal pinna similar to the lateral ones)

9. Lateral pinnae 1 or 2 pairs A. pearce

9. Lateral pinnae 3 or more pairs

10. Pinnae serrate; laminae abaxially without glandular hairs A. serra

10. Pinnae entire; laminae abaxially with inconspicuous glandular hairs A. juglandifolium

8. Lamina apices pinnatifid or flagellate, with terminal bud

11. Lamina apices flagellate, with a terminal bud

12. Laminae 1-pinnate-pinnatifid, the bases gradually tapered A. hallii

12. Laminae 1-pinante, the bases truncate or nearly so ....... A. cirrhatum

11. Lamina apices pinnatifid, without buds

13. Rachises conspicuously winged A. auritum

13. Rachises not conspicuously winged

14. Acroscopic margin of the pinnae strongly dentate ... A. formosum

14. Acroscopic margin of the pinnae slightly serrate .... A. discrepans

Asplenium angustum Sw., Kongl. Vetensk. Acad. Handl. 1817(1): 66, tab. 4, fig. 1. 1817.

Figures: 5C, D

Habit/Habitat: Herb; epiphyte in forest on terra firme.

Material examined: Cruzeiro do Sul, G.T. Prance et al. 12637 (NY); Mâncio Lima, D.C. Daly et al. 8953 (NY, UFACPZ).

World Distribution: N South America to Bolivia.

Characterized by laminae $1.5-2.5 \mathrm{~cm}$ wide, gradually attenuate toward the apex and base. The sori tend to occupy medial and distal portions of the laminae, and they are more oblique to the rachis (angle $30^{\circ}-45^{\circ}$ ) compared to the similar Asplenium serratum and A. stuebelianum (angle $50^{\circ}-75^{\circ}$ ).

Asplenium auritum Sw., J. Bot. (Schrader) 1800(2): 52. 1801.

Figures: 1C, 5E, F

Habit/Habitat: Herb; epiphyte in forest on terra firme.

Material examined: Manoel Urbano, D.C. Daly et al. 11466 (NY); Mâncio Lima, G.T. Prance et al. 11977 (NY); Marechal Thaumaturgo, D.C. Daly 10531 (NY); Porto Valter, P.J.M. Maas et al. P12930 (MG, NY), P.J.M. Maas et al. P13180 (NY); Santa Rosa, D.C. Daly et al. 11305 (NY); Sena Madureira, M. Silveira et al. 617 (NY, UFACPZ); Tarauacá, M. Silveira et al. 921 (NY), G.T. Prance 7247 (MG, NY), G.T. Prance et al. 7382 (NY).

World Distribution: S Mexico, Antilles, Mesoamerica, and N South America to Bolivia.

Easily recognized by epiphytic habit, conspicuously winged rachises, and firm-textured laminae.
Asplenium brasiliense Sw., Kongl. Vetensk. Acad. Handl. 1817(1): 65, tab. 3, fig. 4. 1817.

Figures: $5 \mathrm{G}, \mathrm{H}$

Habit/Habitat: Herb; terrestrial on the banks of rivers.

Material examined: Tarauacá, F.A. Michelangeli et al. 1383 (NY).

World Distribution: Paraguay, Argentina, Uruguay, and Brazil.

The only species of Asplenium in Acre with areolate veins.

Asplenium cirrhatum Rich. ex Willd., Sp. Pl. 5(1): 321. 1810.

Figures: 6A, B

Habit/Habitat: Herb; epiphyte on flooded vegetation.

Material examined: Cruzeiro do Sul, G.T. Prance et al. 12202 (NY); Mâncio Lima, M. Silveira et al. 1245 (NY).

World Distribution: Mexico, Antilles, Mesoamerica, and tropical South America.

Both Asplenium cirrhatum and A. hallii have a proliferous bud at the apex of the rachis. Asplenium cirrhatum differs by truncate lamina bases and crenate (unlobed) pinnae.

Asplenium cuneatum Lam., Encycl. 2(1): 309. 1786.

Figures: $6 \mathrm{C}, \mathrm{D}$

Habit/Habitat: Herb; epiphyte on terra firme.

Material examined: Porto Valter, P.J.M. Maas et al. P13103 (NY).

World Distribution: Antilles, Mesoamerica, tropical South America, Polynesia, and Africa.

Distinctive among the species in Acre by laminae deltate and 2-pinnate. The pinnules vary from entire to bifid.

Asplenium discrepans Rosenst., Repert. Spec. Nov. Regni Veg. 12: 469. 1913.

Figures: $6 \mathrm{G}, \mathrm{H}$

Habit/Habitat: Herb; terrestrial grows in very wet soils.

Material examined: Rio Branco, C. Pessôa et al. 177 (NY).

World Distribution: Peru, Bolivia, Paraguay, and Brazil (only in Acre).

Characterized by pinnae with margins slightly serrate and lamina apices pinnatifid. The proximal pinnae are reduced in size compared to the medial ones.

Asplenium formosum Willd., Sp. Pl. 5(1): 329. 1810.

Figures: 7A, B

Habit/Habitat: Herb; terrestrial in bamboo forests.

Material examined: Sena Madureira, M. Silveira et al. 4123 (NY).

World Distribution: Mexico, Antilles, Mesoamerica, and tropical South America.

Characterized by dark petioles and rachises, and pinnae pinnatifid with acroscopic margins bidentate.

Asplenium hallii Hook., Sp. Fil. 3: 202. 1860.

Figures: 7C, D

Habit/Habitat: Herb; epiphyte on terra firme.

Material examined: Cruzeiro do Sul, P.J.M. Maas et al. P12794 (NY), L.R. Marinho 251 (NY), J. Prado et al. 1166 (SP, UFACPZ), J. Prado et al. 1306 (SP, UFACPZ), J. Prado et al. 1379 (SP, UFACPZ); Mâncio Lima, J. Prado et al. 1225 (SP, UFACPZ), G.T. Prance et al. 2850 (MG, NY); G.T. Prance et al. $12246 A$ (MG, NY).

World Distribution: N South America to Bolivia.

Characterized by regularly pinnatifid pinnae and a proliferous bud at the tip of the rachis.

Asplenium juglandifolium Lam., Encycl. 2: 307. 1786. 
Figures: 7E, F

Habit/Habitat: Herb; epiphyte on flooded vegetation near river margins. Material examined: Bujari, D.C. Daly et al. 8464 (NY, UFACPZ), D.C. Daly et al. 9330 (NY); Cruzeiro do Sul, G.T. Prance et al. 2786 (MG, NY); Mâncio Lima, J. Prado et al. 1318 (SP, UFACPZ); Marechal Thaumaturgo, D.C. Daly et al. 7764 (NY); Porto Acre, A.R.S. Oliveira et al. 761 (NY); Rodrigues Alves, J. Prado et al. 1262 (SP, UFACPZ).

World Distribution: Mexico, Jamaica, Mesoamerica, and tropical South America.

Resembling Asplenium serra but differing by entire pinnae, sori more spreading with respect to the pinna rachises, and presence of inconspicuous glandular hairs on the laminae abaxially.

Asplenium pearcei Baker, Syn. Fil. (ed. 2) 483. 1874.

Figures: 8A, B

Habit/Habitat: Herb; epiphyte in terra firme forests.

Material examined: Brasiléia, D.C. Daly et al. 11906 (NY); Cruzeiro do Sul, J. Prado et al. 1350 (UFACPZ); Feijó, P. Delprete et al. 8543 (NY); Mâncio Lima, G.T. Prance et al.12168(NY); Manoel Urbano, D.C. Daly et al. 11226 (NY); Marechal Thaumaturgo, D.C. Daly et al. 7336 (NY, UFACPZ); Porto Valter, S.R. Lowrie et al. 525 (NY), P.J.M. Maas et al. P13295 (NY), G.T. Prance et al. P13269 (NY); Santa Rosa, D.C. Daly et al. 9948 (NY); Sena Madureira, M. Silveira 4126 (NY); Tarauacá, C. Herinhaus et al. 397 (NY); Without locality, J. Jangoux et al. 85-096 (MG, NY).

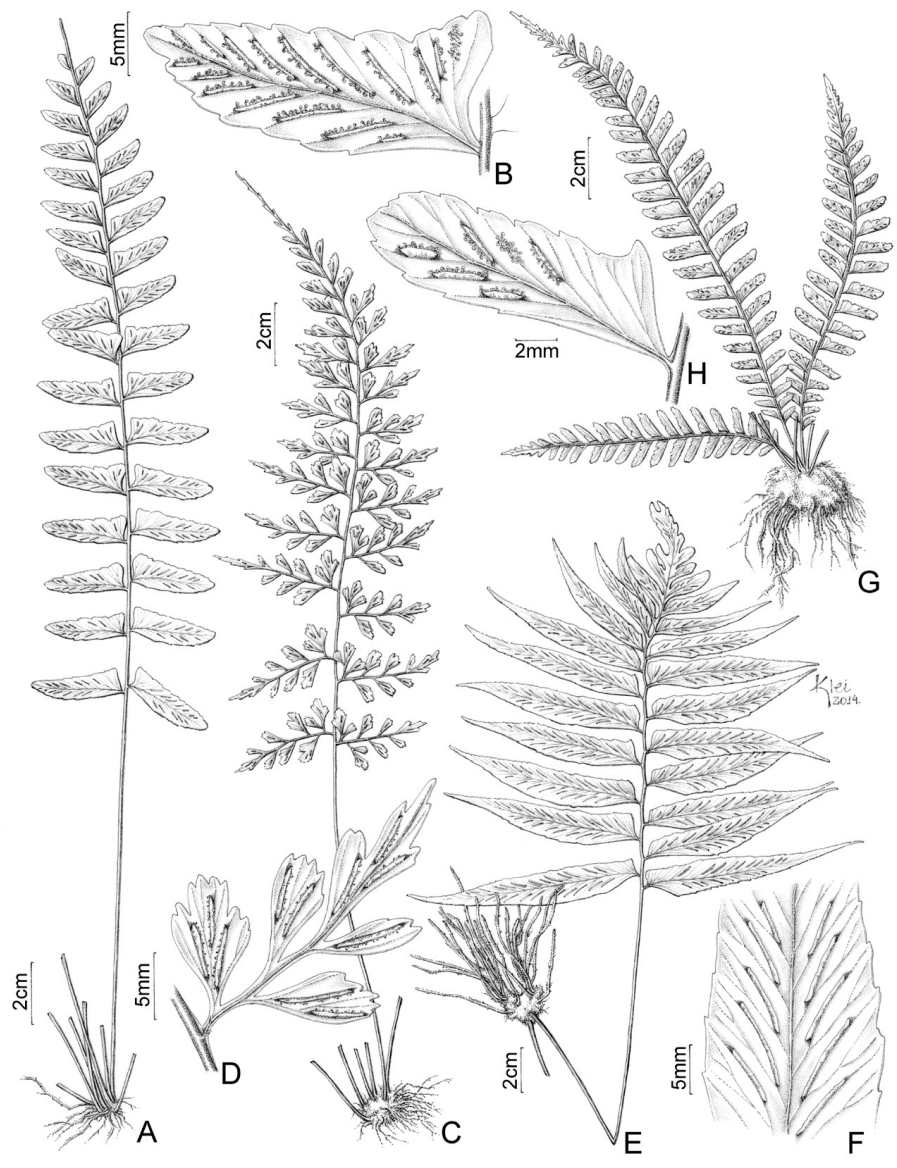

Figure 6. A, B. Asplenium cirrhatum (Silveira et al. 1245, NY). A. Habit. B. Sori. C, D. Asplenium cuneatum (Maas et al. P13103, NY). C. Habit. D. Sori. E, F. Hymenasplenium delitescens (Daly et al. 9811, NY). E. Habit. F. Sori. G, H. Asplenium discrepans (Pessôa et al. 177, NY). G. Habit. H. Sori.
World Distribution: N South America to Bolivia.

The laminae of Asplenium pearcei vary from entire to 1-pinnate. When 1-pinnate, the terminal pinna is similar the lateral ones in shape and size. Only one or two lateral pair(s) of pinnae are produced.

Asplenium pedicularifolium A. St.-Hil., Voy. Distr. Diam. 1: 380. 1833.

Figures: 8C, D

Habit/Habitat: Herb; epiphyte in forests on terra firme.

Material examined: Mâncio Lima, D.C. Daly et al. 8926 (NY, UFACPZ), G.T. Prance et al. 12246 (NY).

World Distribution: Guianas, Ecuador, Peru, and N Brazil.

Characterized by elliptic laminae (tapered proximally and distally) with the main rachis overlapped by basal pinnules. The laminae dry dark brown.

Asplenium serra Langsd. \& Fisch., P1. Voy. Russes Monde 1: 16, tab. 19. 1810.

Figures: 8E, F

Habit/Habitat: Herb; epiphyte on trunk in the floor of forest on terra firme. Material examined: Mâncio Lima, J. Prado et al. 1224 (SP, UFACPZ).

World Distribution: Mexico, Antilles, Mesoamerica, and tropical and subtropical South America.

Characterized by 1-pinnate laminae, serrate pinnae, and sori at a very acute angle (sometimes nearly parallel) with respect to the pinna rachises. The terminal segment of the lamina is conform (i.e., similar in shape to

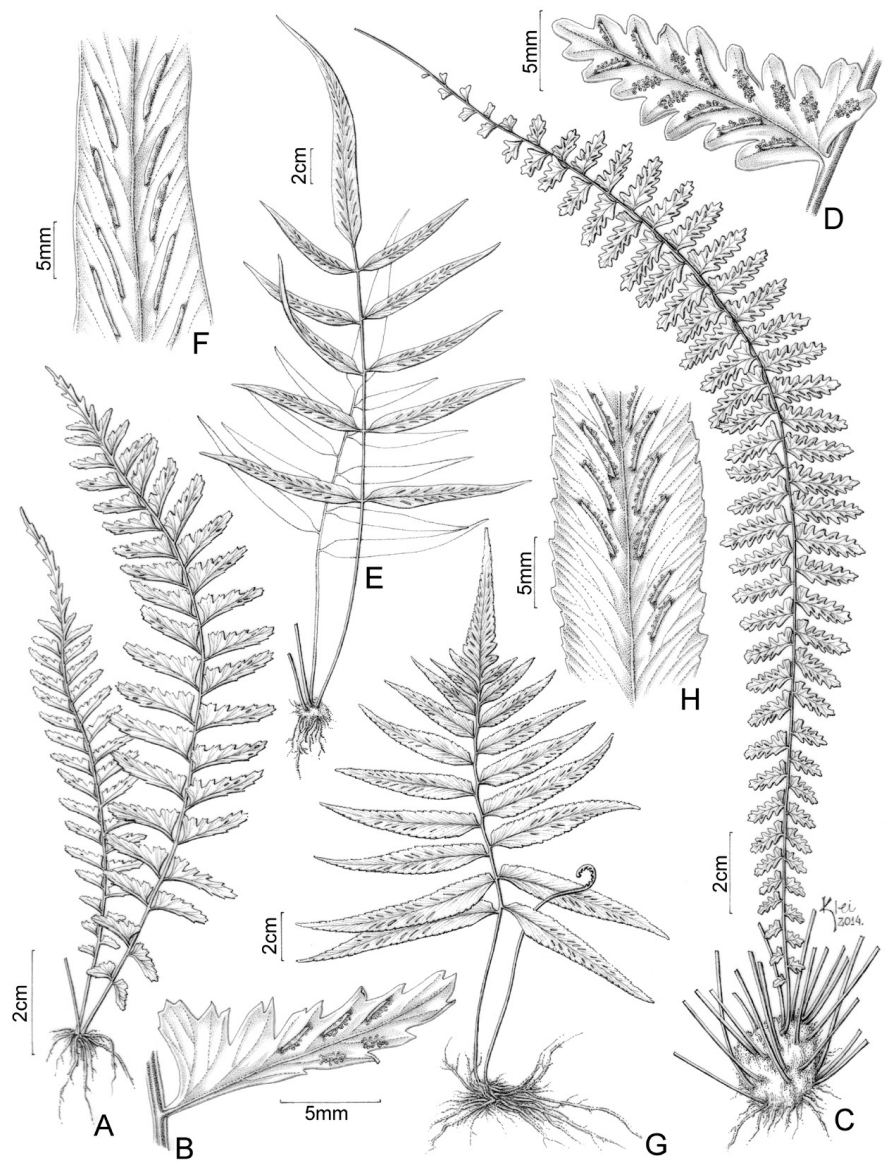

Figure 7. A, B. Asplenium formosum (Silveira et al. 4123, NY). A. Habit. B. Sori. C, D. Asplenium hallii (Prado et al. 1306, SP). C. Habit. D. Sori. E, F. Asplenium juglandifolium (Prado et al. 1318, SP). E. Habit. F. Sori. G, H. Hymenasplenium delitescens (Croat et al. 86026, NY). G. Habit. H. Sori. 
the lateral pinnae) or nearly so. The rhizome scales are black, distinctly clathrate, with filiform apices.

Asplenium serratum L., Sp. P1. 2: 1079. 1753.

Figures: 9A, B

Habit/Habitat: Herb; epiphyte in forest on terra firme and on flooded vegetation near river margins.

Material examined: Assis Brasil, D.C. Daly et al. 9808 (NY, UFACPZ); Brasiléia, D.C. Daly et al. 6771 (NY, UFACPZ); Bujari, D.C. Daly et al. 9328 (NY), M. de Pardo et al. 80 (NY); Cruzeiro do Sul, D.C. Daly et al. 11717 (NY), P.J.M. Maas et al. P12863 (MG, NY), J. Prado et al. 1187 (SP, UFACPZ), J. Prado et al. 1197 (UFACPZ), J. Prado et al. 1317 (SP, UFACPZ), J. Prado et al. 1340 (SP, UFACPZ), J. Prado et al. 1382 (SP, UFACPZ), G.T. Prance et al. 2785 (NY); Mâncio Lima, J. Prado et al. 1135 (SP, UFACPZ); Manoel Urbano, D.C. Daly et al. 9136 (NY), D.C. Daly et al. 11241 (NY); Plácido de Castro, C. Figueiredo \& I. Riveiro 592 (NY), L.G. Lohmann \& E.C. de Oliveira 492 (NY); Rodrigues Alves, J. Prado et al. 1237 (SP, UFACPZ), J. Prado et al. 1255 (SP, UFACPZ), J. Prado et al. 1291 (SP, UFACPZ); Santa Rosa, D.C. Daly et al. 10053(NY, UFACPZ), D.C. Daly et al. 10984 (NY), D.C. Daly et al. 11106 (NY); Sena Madureira, D.C. Daly et al. 7841 (NY, UFACPZ).

World Distribution: S Florida, Mexico, Antilles, Mesoamerica, and tropical and subtropical South America.

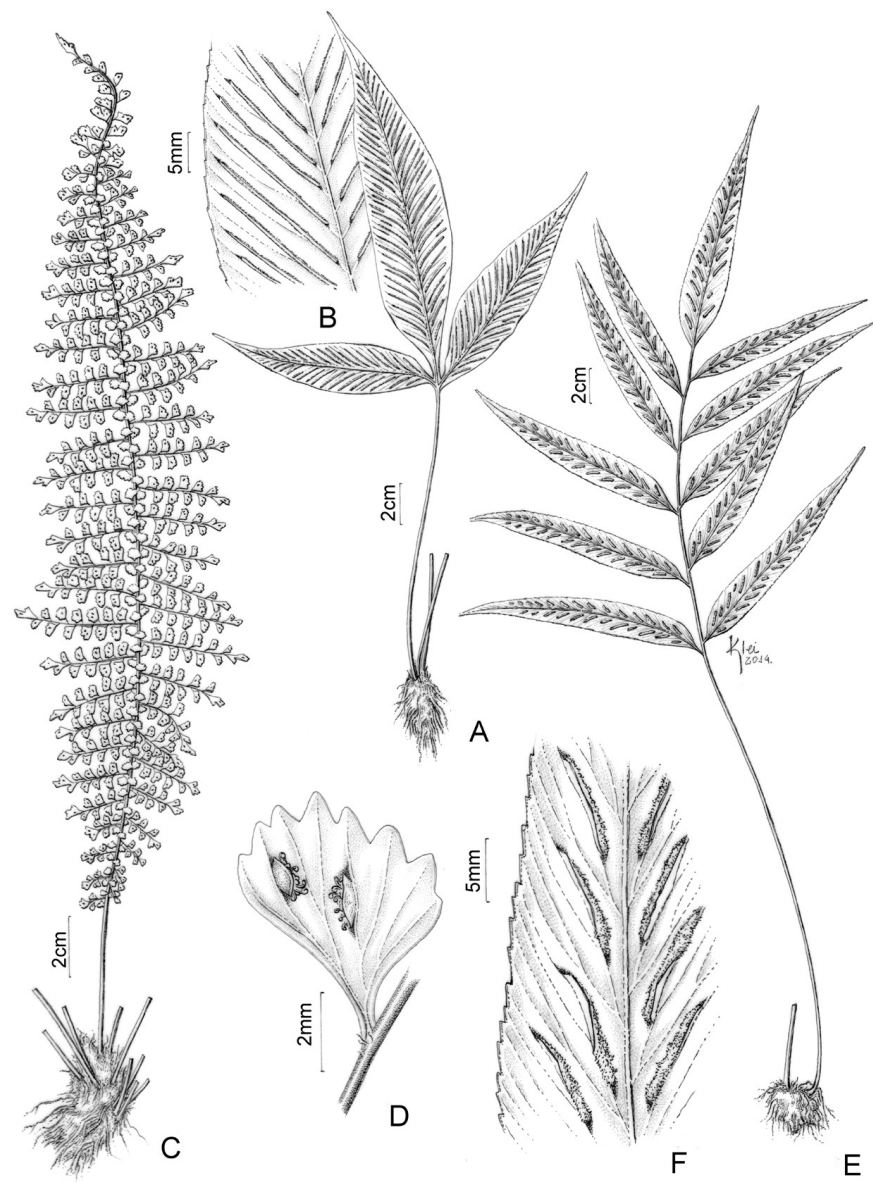

Figure 8. A, B. Asplenium pearcei (Silveira et al. 4126, NY). A. Habit. B. Sori. C, D. Asplenium pedicularifolium (Daly et al. 8926, NY). C. Habit. D. Sori E, F. Asplenium serra (Prado et al. 1224, SP). E. Habit. F. Sori.
The greenish or light brown petioles distinguish it from Asplenium stuebelianum, which has dark brown to black petioles. Far more common than A. stuebelianum, the other species in Acre with simple, entire leaves.

Asplenium stuebelianum Hieron., Hedwigia 47: 222. 1908.

Figures: 9C, D

Habit/Habitat: Herb; epiphyte or terrestrial, in open forest with bamboo. Material examined: Feijó, D.C. Daly et al. 8500 (NY); Mâncio Lima, D.C. Daly et al. 8952 (NY, UFACPZ); Marechal Thaumaturgo, D.C. Daly et al. 10524 (NY), D.C. Daly et al. 10552 (NY); Rio Branco, D.C. Daly et al. $6871 A$ (NY, UFACPZ).

World Distribution: Tropical South America.

Less common than the similar Asplenium serratum. Many specimens of $A$. stuebelianum have subterminal buds. The differences pointed out in the key separate these species.

Hymenasplenium Hayata, Bot. Mag. (Tokyo) 41(492): 712. 1927.

Similar to Asplenium but differing by rhizomes creeping, slightly flattened dorsiventrally, and bearing swollen petiole bases. The leaves are arranged distichously on dorso-lateral surfaces of the rhizomes. The Neotropical species were revised by Murakami \& Moran (1993), who recognized 10 species.

Pantropical; ca. 30 species, 1 in Acre.

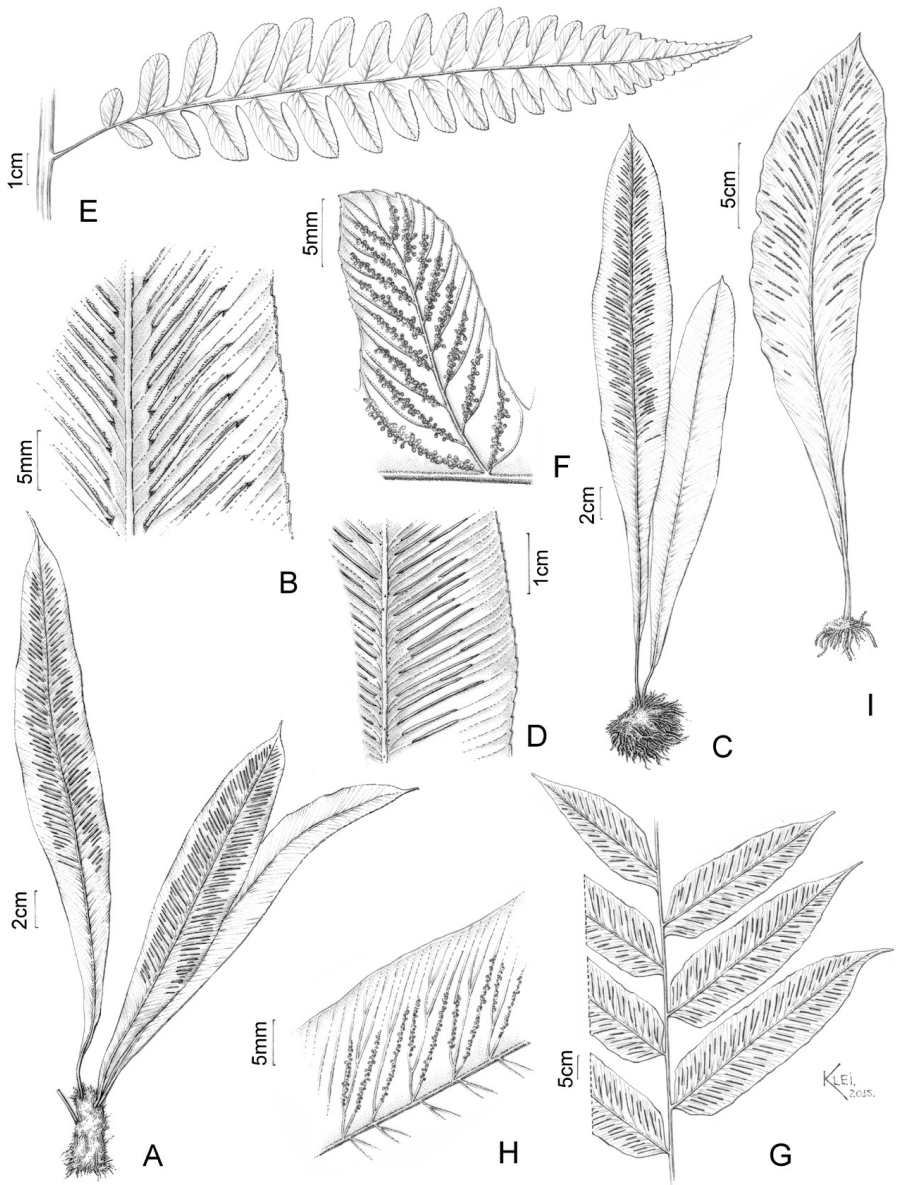

Figure 9. A, B. Asplenium serratum (Prado et al. 1317, SP). A. Habit. B. Sori C, D. Asplenium stuebelianum (Daly et al. 10524, NY). C. Habit. D. Sori E, F. Diplazium ambiguum (Daly et al. 10464, NY). E. Pinna. F. Fertile segment. G, H. Diplazium andicola (Pinard et al. 812, NY). G. Part of a fertile frond. H. Venation and sori. I. Diplazium praestans (Prance et al. 7400, NY). I. Habit. 
Hymenasplenium delitescens (Maxon) L. Regalado \& Prada, Amer. Fern J. 101(4): 278. 2011[2012]. Diplazium delitescens Maxon, Contr. U.S. Natl. Herb. 10: 497, tab. 56, fig. 1. 1908.

Figures: 6E, F, 7G, H

Habit/Habitat: Herb; terrestrial grows riverside vegetation and on terra firme forest.

Material examined: Assis Brasil, D.C. Daly et al. 9811 (NY, UFACPZ); Cruzeiro do Sul, D.C. Daly et al. 11707 (NY); Marechal Thaumaturgo, D.C. Daly et al. 7337 (NY, UFACPZ); Porto Acre, T.B. Croat et al. 86026 (NY); Rio Branco, H.C. de Lima et al. 2078 (RB).

World Distribution: S Mexico, Antilles, Mesoamerica, and N South America to Bolivia.

Characterized by thin leaves, pinnatifid lamina apices, and pinnae disposed at almost right angle to the rachis. The proximal pinnae are large $7-10 \mathrm{~cm}$ long and not reduced. Rachises not winged or inconspicuously winged. Veins vary from 1-4 forked.

\section{ATHYRIACEAE}

Terrestrial or rupicolous. Distinguished from Aspleniaceae, which also has elongate sori, by non-clathrate rhizome scales, and 2 petiolar vascular bundles that unite distally to form a "U" (in Asplenium they form an "X"). Athyriaceae are always terrestrial, the Aspleniaceae are terrestrial or epiphytic. Other characters constant within the Athyriaceae are sterile and fertile leaves monomorphic; venation free or areolate (without included veinlets), and sori elongate to linear or J-shaped, usually indusiate.

Cosmopolitan; 3 genera, ca. 650 species. In Acre, 1 genus, 3 species.

Diplazium Sw., J. Bot. (Schrader) 1800(2): 4, 61. 1801.

Characterized by sori paired back-to-back along the same vein-what is termed a "diplazioid sorus." This soral character is nearly unique among ferns. Diplazium is always terrestrial, whereas the similar Asplenium may be either terrestrial or epiphytic. Usually non-clathrate rhizome scales help distinguish the genus from Asplenium, which has clathrate rhizome scales. The number of annulus cells in the two genera also differs: 15-20 in Diplazium, and 20-28 in Asplenium.

Pantropical and subtropical; ca. 350 species, 3 in Acre.

1. Laminae 2-pinnate-pinnatifid proximally D. ambiguum

1. Laminae simple (entire) or 1-pinnate

2. Laminae simple, entire; veins areolate D. praestans

2. Laminae 1-pinnate; veins free D. andicola

Diplazium ambiguum Raddi, Opusc Sci. 3: 292. 1819.

Figures: 9E, F

Habit/Habitat: Herb; terrestrial on disturbed area of terra firme.

Material examined: Marechal Thaumaturgo, D.C. Daly et al. 10464 (NY). World Distribution: tropical South America.

Characterized by laminae 2-pinnate-pinnatifid basally and 1-pinnate-pinnatifid distally.

Diplazium andicola (Stolze) M. Kessler \& A.R. Sm., Brittonia 59(2): 196. 2007. Diplazium grandifolium (Sw.) Sw. var. andicola Stolze, Fieldiana, Bot., n.s., 27: 82. 1991.

Figures: 9G, H

Habit/Habitat: Herb; terrestrial in forest on terra firme near stream margins.
Material examined: Cruzeiro do Sul, D.C. Daly et al. 7394 (NY, UFACPZ); Marechal Thaumaturgo, D.C. Daly et al. 10302 (NY); Sena Madureira, D.C. Daly et al. 13271 (RB); Xapuri, M. Pinard et al. 812 (NY).

World Distribution: Mexico, Antilles, Mesoamerica, and N South America.

Characterized by laminae 1-pinnate, pinnae entire and 8-15 $\times 2.5-4 \mathrm{~cm}$, and veins free. Proximal and medial pinnae oblong-elliptic or oblonglanceolate, with the bases either cuneate or truncate. Most similar is Diplazium mattogrossense A. Samp., which apparently differs by pinna pairs 10-12 (vs. 7-10 pairs in D. andicola). Also, D. mattogrossense has pinna bases truncate and with an acroscopic auricle.

Diplazium praestans (Copel.) Maxon \& C.V. Morton, Contr. U.S. Natl. Herb. 38: 41. 1967. Athyrium praestans Copel., Amer. Fern J. 38(4): 132, tab. 11. 1948.

Figures: 9I

Habit/Habitat: Herb; terrestrial in forests on terra firme.

Material examined: Marechal Thaumaturgo, D.C. Daly et al. 7721 (NY, UFACPZ); Tarauacá, G.T. Prance et al. 7400 (MG, NY).

World Distribution: N South America to Bolivia.

Characterized by entire oblong leaves with areolate veins.

\section{BLECHNACEAE}

Characterized by reddish young leaves and elongate sori parallel and on both sides of the midribs. The indusia open toward the midrib, not the pinna margin. The leaves are usually entire to 1-pinnate (Blechnum), or 2-pinnate (in Salpichlaena).

Although a member of the Eupolypods II in the Polypodiales, the Blechnaceae have the typical petiolar vascular bundle arrangement of Eupolypods I; that is, there are two enlarged adaxial bundles and an arc of several to many smaller ones beneath.

Cosmopolitan; 24 genera, ca. 265 species. In Acre, 2 genera, 3 species.

1. Plants terrestrial; leaves 1-pinnate Blechnum

1. Plants climbing; leaves 2-pinnate Salpichlaena

Blechnum L., Sp. Pl. 2: 1077. 1753.

Characterized by the presence of stolons, non-climbing; 1-pinnate or pinnatisect leaves usually tapered and pinnatifid toward the apex.

Pantropical; 30 species, 1 in Acre.

Blechnum occidentale L., Sp. P1. 2: 1077. 1753.

Figures: 10A, B

Habit/Habitat: Herb; terrestrial in forest on terra firme.

Material examined: Cruzeiro do Sul, P.J.M. Maas et al. P13242 (NY).

World Distribution: SE USA, Mexico, Antilles, Mesoamerica, and tropical and subtropical South America.

Characterized by deltate, 1-pinnate laminae. The species reproduces asexually by stolons radiating from the erect rhizomes. Terrestrial along trails and roads.

Salpichlaena J. Sm., J. Bot. (Hooker) 4: 168. 1841.

Characterized by twining habit of the rachises and 2-pinnate climbing leaves. The twining leaves may reach the top of the trees and are typically 10-12 m long. The non-climbing leaves are 1-pinnate. Only one other genus of ferns, Lygodium, climbs by means of a twining rachis. Twining rachises are unknown in angiosperms. Another unusual character of Salpichlaena is that the indusia, with sporangia attached, fall off with age. No other fern genus does this.

Neotropical; 3 species, 2 occur in Acre 
Prado, J. et al.

1. Fertile pinnae with very narrow, with contracted laminar tissue

S. hookeriana

1. Fertile pinnae with laminar tissue expanded

S. volubilis

Salpichlaena hookeriana (Kuntze) Alston, Bull. Misc. Inform. Kew 1932(7): 312. 1932. Spicanta hookeriana Kuntze, Revis. Gen. P1. 2: 821. 1891.

Figures: 10C, D

Habit/Habitat: Herb; climbing on flooded vegetation near stream margins.

Material examined: Cruzeiro do Sul, J. Prado et al. 1161 (SP, UFACPZ); Mâncio Lima, J. Prado et al. 1229 (SP, UFACPZ).

World Distribution: N South America.

Characterized by narrow, contracted fertile pinnae nearly lacking any green laminar tissue. The sori cover the entire pinnae surface. Buds occasionally occur in the axils of the pinnae. This species is known only from Amazonian Brazil and neighboring countries.

Salpichlaena volubilis (Kaulf.) J. Sm., J. Bot. (Hooker) 4: 168. 1841 Blechnum volubile Kaulf., Enum. Filic. 159. 1824.

Figures: 10E, F

Habit/Habitat: Herb; climbing on terra-firme vegetation near stream margins

Material examined: Cruzeiro do Sul, J. Prado et al. 1200 (SP, UFACPZ).

World Distribution: Antilles, Mesoamerica, and tropical South America.
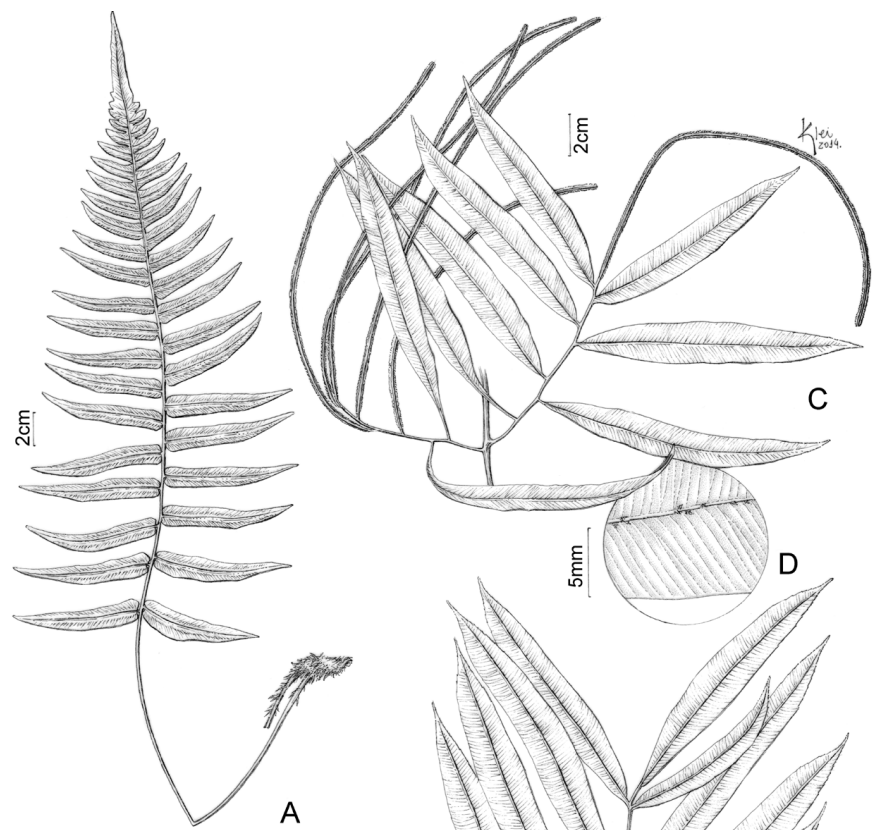

A

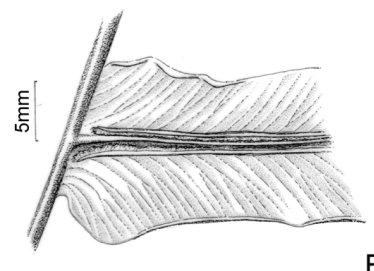

B

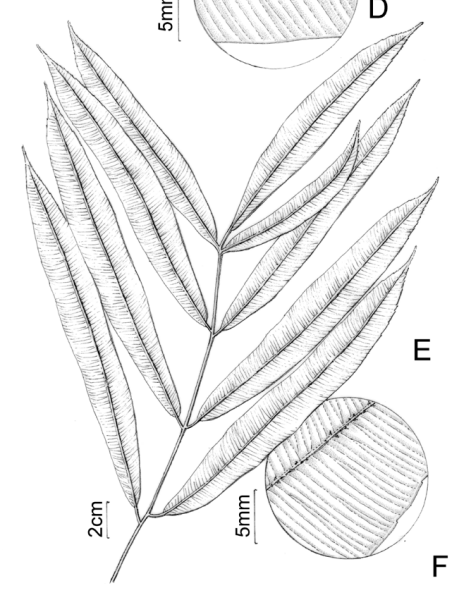

Figure 10. A, B. Blechnum occidentale (Maas et al. P13242, NY). A. Habit. B. Sori. C, D. Salpichlaena hookeriana (Prado et al. 1229, SP). C. Part of a frond. D. Venation of the sterile frond. E, F. Salpichlaena volubilis (Prado et al. 1200, SP).

E. Part of a frond. F. Venation of the sterile frond.
In contrast to Salpichlaena hookeriana, $S$. volubilis occurs in upland forests and is widespread in the Neotropics.

\section{CYATHEACEAE}

Characterized by arborescent habit and large divided leaves. The Cyatheaceae, commonly called tree ferns, are a member of the order Cyatheales. The order, which has eight families, includes the Metaxyaceae, a primarily Amazonian family. Some of the species studied here were recently treated by Lehnert (2016).

Pantropical; 3 genera, ca. 650 species. In Acre, 2 genera, 4 species.

1. Petiole scales lacking dark marginal setae (magnification needed); petiole bases not spiny, or if so, the spines not shiny black; plants usually single-stemmed

Cyathea

1. Petiole scales with dark marginal setae (magnification needed); petiole bases spiny, the spines shiny black; plants multiple-stemmed

Alsophila

Alsophila R. Br., Prodr. 158. 1810.

Characterized by arborescent habit and dark-setulose petiole scales (magnification needed to see setulae). The trunks branch at the base, with the branches growing downward into the soil and not producing leaves. In the soil, they grow away from the main stem and then turn erect, forming a typical leaf-bearing stem; in this way multiple-stemmed colonies are formed.

Pantropical; ca. 275 species, 1 in Acre.

Alsophila cuspidata (Kunze) D.S. Conant, J. Arnold Arbor. 64: 371.1983 Cyathea cuspidata Kunze, Linnaea 9: 101. 1834.

Figures: $11 \mathrm{~A}-\mathrm{D}$

Habit/Habitat: Tree fern; forest on terra firme.

Material examined: Brasiléia, D.C. Daly et al. 9881 (NY), D.C. Daly et al. 11886 (NY); Marechal Thaumaturgo, D.C. Daly et al. 7427 (NY, UFACPZ).

World Distribution: Mesoamerica and tropical South America.

Characterized by black sharp spines on the petiole bases, abruptly contracted lamina apices, minute stellate hairs on the abaxial surface of the laminae, and globose indusia.

Cyathea Sm., Mém. Acad. Roy. Sci. (Turin) 5: 416. 1793.

The second largest genus of Cyatheales, with 265 species. The Acre species may be distinguished by the arborescent habit, and petiole scales lacking dark setae (magnification needed to determine this). The Acre species lack indusia, although these structures may be found in other species of Cyathea.

Pantropical, not in Africa and continental Asia, only a few in Polynesia, Melanesia, and Indonesia; 265 species, 3 in Acre.

1. Spines of the petioles and rachises ca. 1-2 mm long ... C. pilosissima

1. Spines of the petioles and rachises $1-5 \mathrm{~mm}$ long

2. Leaves 2-pinnate-pinnatifid; costae not spiny; apex of the ultimate segments round; most of the veins simple

C.pungens

2. Leaves 2-pinnate-pinnatisect; costae spiny; apex of the ultimate segments acute; most of the veins furcate

C. microdonta

Cyathea microdonta (Desv.) Domin, Pteridophyta 263. 1929. Polypodium microdontum Desv., Ges. Naturf. Freunde Berlin Mag. Neuesten Entdeck. Gesammten Naturk. 5: 319. 1811.

Figures: 11E, F

Habit/Habitat: Tree fern; forest near river margins. 
Material examined: Cruzeiro do Sul, J. Prado et al. 1190 (SP, UFACPZ); Manoel Urbano, D.C. Daly et al. 11558 (NY).

World Distribution: S Mexico, Antilles, Mesoamerica, and N South America to Bolivia.

Characterized by spines $3-5 \mathrm{~mm}$ long on the petioles, rachises, and pinna rachises, and by non-indusiate sori. The spines are the same color as the petioles and rachises, unlike Alsophila where they are shiny and black. The leaves are 2-pinnate-pinnatisect, and the ultimate segments 1-2 mm wide with acute apices. Most of the veins are furcate. This species often produces short, erect lateral branches from the base of the trunk. The other species do not produce such branches.

Cyathea pilosissima (Baker) Domin, Pteridophyta 262. 1929. Polypodium pilosissimum Baker, Syn. Fil. (Hook. \& Baker), ed. 2: 457. 1874.

Figures: $11 \mathrm{G}, \mathrm{H}$

Habit/Habitat: Tree fern; in disturbed forest on terra firme.

Material examined: Mâncio Lima, D.C. Daly et al. 11603 (NY); Rodrigues Alves, J. Prado et al. 1231 (SP, UFACPZ).

World Distribution: Mesoamerica and N South America.

Characterized by petioles sparsely beset with inconspicuous short (1-2 mm long) spines. The spines are most evident toward the petiole bases. The segment margins are dentate, and the veins are pubescent on both surfaces.

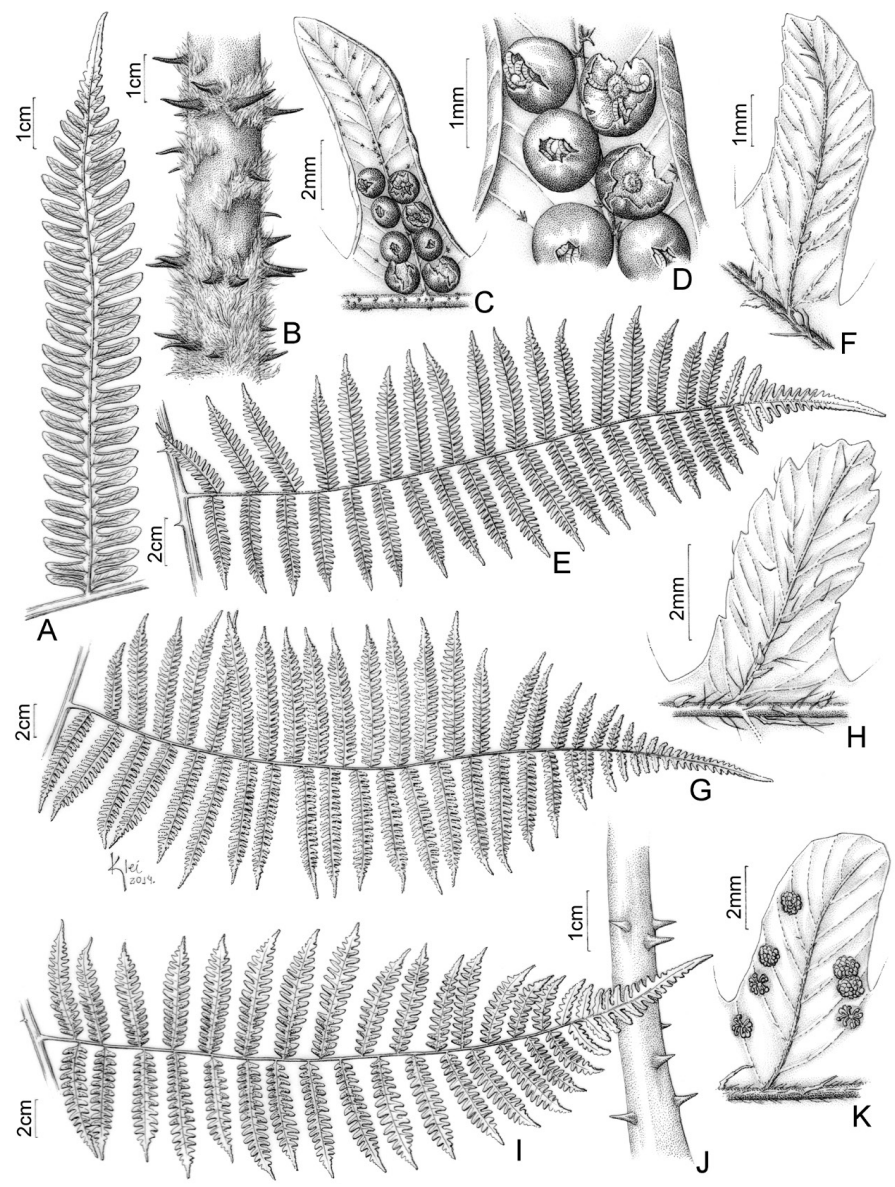

Figure 11. A-D. Alsophila cuspidata (Daly et al. 7427, NY). A. Pinnule. B. Base of the petiole. C. Fertile segment. D. Sori. E, F. Cyathea microdonta (Prado et al. 1190, SP). E. Pinna. F. Sterile segment. G, H. Cyathea pilosissima (Prado et al. 1231, SP). G. Pinna. H. Sterile segment. I-K. Cyathea pungens (Daly et al. 11175, NY). I. Pinna. J. Base of the petiole. K. Fertile segment.
Cyathea pungens (Willd.) Domin, Pteridophyta 263. 1929. Polypodium pungens Willd., Sp. Pl. 5: 206. 1810.

Figures: 1D, 11I-K

Habit/Habitat: Tree fern; flooded vegetation near stream margins.

Material examined: Brasiléia, D.C. Daly et al. 6823 (NY, UFACPZ), L. Ferreira \& L.C. Ming 117 (NY, UFACPZ); Mâncio Lima, D.C. Daly et al. 1252 (NY); Manoel Urbano, D.C. Daly et al. 9087 (NY); Marechal Thaumaturgo, D.C. Daly et al. 10239 (NY); Santa Rosa, D.C. Daly et al. 10165 (NY), D.C. Daly et al. 11175 (NY).

World Distribution: Antilles and N South America to Bolivia.

Characterized by sparsely spiny petioles and rachises, the spines ca. 1-3(-4) mm long. The spines also have the same color of the petioles and rachises, unlike Alsophila, which has black shiny spines that contrast strongly with the color of the petiole. The leaves are 2-pinnate-pinnatifid and the ultimate segments vary $3-5 \mathrm{~mm}$ wide and the apex is rounded. Most of the veins are simple.

\section{DENNSTAEDTIACEAE}

The family is characterized by creeping rhizomes that are thinly pubescent (scales only in Histiopteris (J. Agardh) J. Sm.), the presence of epipetiolar buds (i.e., new rhizomes formed at the bases of the petioles), and petioles containing an omega-shaped vascular bundle (this sometimes hard to discern in Pteridium), with the open end of the omega oriented adaxially.

Cosmopolitan; 10 genera, ca. 265 species. In Acre, 2 genera, 3 species.

1. Sori round, formed in sinus, supplied by a single vein; indusia cup-shaped Dennstaedtia

1. Sori linear, not formed in sinus, supplied by several to many veins; indusia linear....

Pteridium

Dennstaedtia Bernh., J. Bot. (Schrader) 1800(2): 124. 1800[1801].

Characterized by creeping rhizomes; epipetiolar buds; an omega-shaped petiolar vascular bundle; marginal sori supplied by a single vein; and cup-shaped indusia. According to the PPG I (2016), Dennstaedtia as currently circumscribed is polyphyletic.

Tropical and temperate; ca. 70 species, 1 species in Acre.

Dennstaedtia bipinnata (Cav.) Maxon, Proc. Biol. Soc. Washington 51: 39. 1938. Dicksonia bipinnata Cav., Descr. P1. 174. 1802.

Figures: $12 \mathrm{~A}-\mathrm{C}$

Habit/Habitat: Tree fern; flooded vegetation near stream margins.

Material examined: Manoel Urbano, D.C. Daly et al. 11418 (NY).

World Distribution: S Mexico, Antilles, Mesoamerica, and N South America to Bolivia.

Characterized by 3-4-pinnate-pinnatisect leaves, ultimate segments acutely to sub-acutely dentate, rachises and pinna-rachises grooved adaxially, sori borne in the sinuses, and indusia cup-shaped. Collected only once in Acre.

Pteridium Gled. ex Scop., Fl. Carniol. 169-170. 1760, nom. cons.

Characterized by laminae 3- or 4-pinnate, deltate or pentagonal; sori marginal, covered by a reflexed indusium; sterile margins also reflexed. It is the only fern genus that has the segment margins revolute (i.e., a "false indusium") when sporangia are absent beneath. In other genera with false indusia (e.g., Adiantum L., Pteris L.), indusia form only when sporangia are present.

Cosmopolitan; ca. 15 species, 1 in Acre. 
Pteridium caudatum (L.) Maxon, Proc. U.S. Natl. Mus. 23(1226): 631. 1901. Pteris caudata L., Sp. Pl. 2: 1075-1076. 1753.

Figures: 12D-F

Habit/Habitat: Herb; terrestrial in cleared land beside trails.

Material examined: Cruzeiro do Sul, J. Prado et al. 1178 (SP, UFACPZ); Mâncio Lima, G.T. Prance et al. 2864 (NY).

World Distribution: S Florida, Mexico, Antilles, Mesoamerica, and N South America to Bolivia.

Characterized by long-caudate pinna and pinnule apices, and by short-decurrent bases of ultimate segments. This species is here recognized in the broad sense, as has been traditionally done. It belongs to a complex of species that need further studies to determine the level of ploidy of the Amazonian populations.

\section{DESMOPHLEBIACEAE}

Characterized by two vascular bundles in thick petiole bases; imparipinnate laminae; alternate pinnae with the distal ones decurrent, and veins connected at the tips by a continuous submarginal vein (Mynssen et al., 2016). Non-clathrate rhizome scales will help distinguish this species from the Asplenium, which also have linear sori. Desmophlebium Mynssen et al. is always terrestrial, never epiphytic as are many species of Asplenium. It also resembles Diplazium (Athyriaceae) but differs by sori not diplazioid (i.e., paired back-to-back along the same vein), and the presence of a submarginal connecting vein.

This family was recently described by Mynssen et al. (2016). It was segregated from the Athyriaceae.

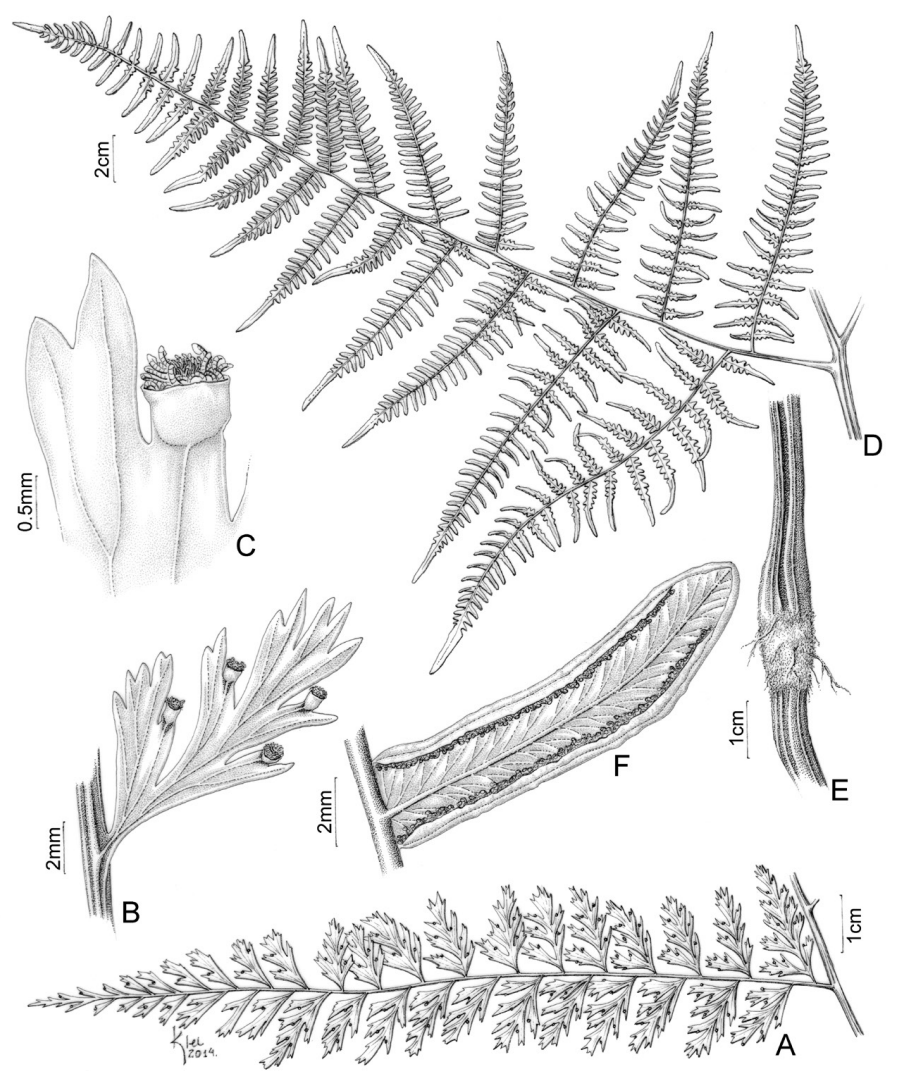

Figure 12. A-C. Dennstaedtia bipinnata (Daly et al. 11418, NY). A. Pinna. B. Fertile segments. C. Sorus. D-F. Pteridium caudatum (Prado et al. 1178, SP). D. Pinna. E. Base of the petiole. F. Fertile segment.
Neotropical; 1 genus, 2 species.

Desmophlebium Mynssen et al., Taxon 65(1): 27, fig. 5 (map). 2016. Characters of the family; 1 species in Acre.

Desmophlebium lechleri (Mett.) Mynssen et al., Taxon 65(1): 28. 2016. Asplenium lechleri Mett., Fil. Lechl. 1: 16, tab. 2. 1856.

Figures: 13A, B

Habit/Habitat: Herb; terrestrial in forest on terra firme.

Material examined: Cruzeiro do Sul, J. Prado et al. 1332 (SP, UFACPZ). World Distribution: Mesoamerica and N South America to Bolivia.

\section{DIDYMOCHLAENACEAE}

Unique among Eupolypods I by elongate sori (Zhang \& Zhang 2015). Also recognized by 2-pinnate leaves with a conform apical segment. Curiously, the lamina tissue has a skunk-like odor when crushed. Further distinctive characters are petioles with 4 or more vascular bundles, the two adaxial ones enlarged, several smaller ones arranged in an arc below (abaxially); pinnules entire and dimidiate; sori elliptic-oblong on the distal ends of veins, with indusium, often somewhat sunken into the lamina, embossed on the adaxial side of the lamina, indusia elongate, centrally attached along a line, opening on both sides of each vein. The rhizomes are erect and massive, to $30 \mathrm{~cm}$ wide.

This family was recently segregated from Dryopteridaceae based on morphological and molecular evidence (Zhang \& Zhang 2015).

Pantropical, but absent in Australia; 1 genus, 1 species.
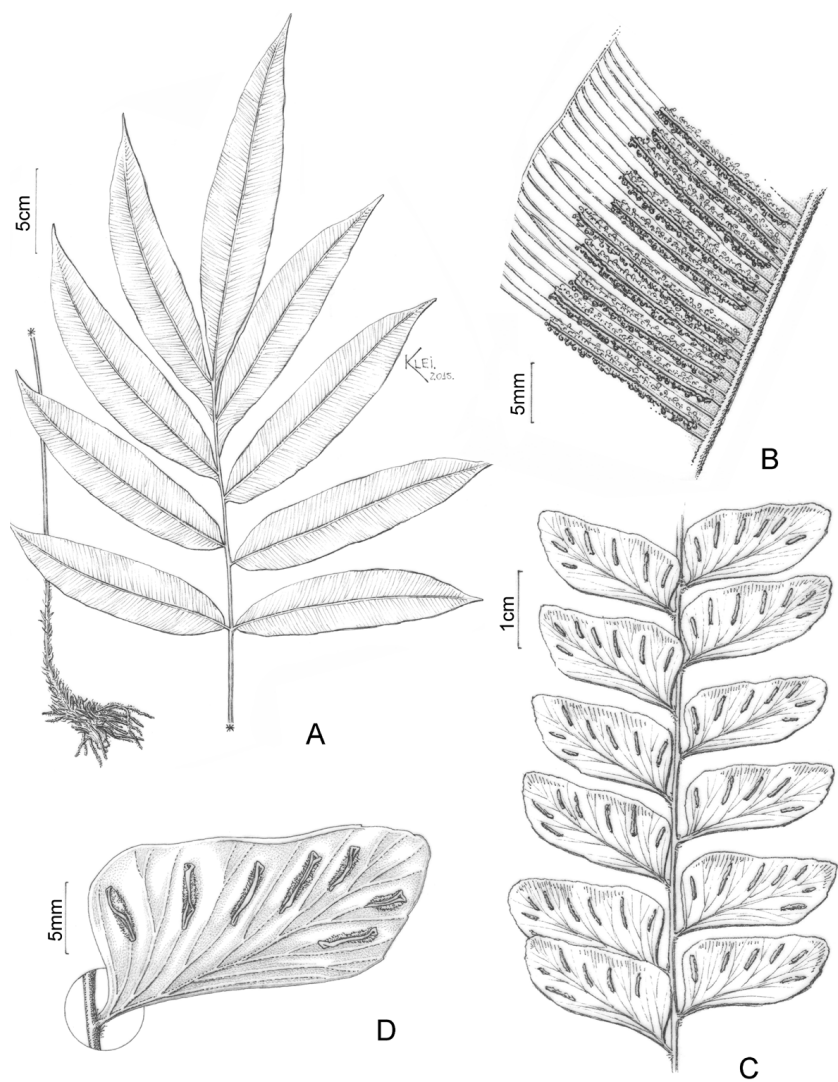

Figure 13. A, B. Desmophlebium lechleri (Prado et al. 1332, SP). A. Part of a fertile frond. B. Venation and sori. C, D. Didymochlaena truncatula (Croat 85188, NY). C. Fertile pinnules. D. Sori. 
Didymochlaena Desv., Mag. Neuesten Entdeck. Gesammten Naturk. Ges. Naturf. Freunde Berlin 5: 303. 1811.

Characters of the family.

Didymochlaena truncatula (Sw.) J. Sm., J. Bot. (Hooker) 4: 196. 1842[1841]. Aspidium truncatulum Sw., J. Bot. (Schrader) 1800(2): 36. 1801.

Figures: 13C, D

Habit/Habitat: Herb; terrestrial in primary forest, undulating terrain, in places dissected by many small streams.

Material examined: Brasiléia, D.C. Daly et al. 9880 (NY, UFACPZ), D.C. Daly et al. 11893 (NY); Cruzeiro do Sul, G.T. Prance et al. 12087 (MG, NY), G.T. Prance et al. 12377 (NY); Mâncio Lima, D.G. Campbell et al. 8913 (NY); Porto Walter, T.B. Croat 85188 (NY).

World Distribution: S Mexico, Antilles, Mesoamerica, and N South America to Bolivia. Tropical Asia and Africa.

\section{DRYOPTERIDACEAE}

A large and diverse family, difficult to characterize morphologically and for which there are no known morphological synapomorphies. It has a petiole vasculature typical of Eupolypods I; namely, two enlarged adaxial bundles with several to many smaller ones arranged in a semicircle below (abaxially). Three subfamilies are recognized: Polybotryoideae ( 7 genera and ca. 98 species), Elaphoglossoideae (11 genera and 883 species), and Dryopteridoideae (six genera and about 1,128 species).

Cosmopolitan; 26 genera, 2,115 species. In Acre, 9 genera, 24 species.

1. Sterile and fertile leaves dimorphic

2. Laminae simple, entire Elaphoglossum

2. Laminae compound

3. Sori round, indusiate Cyclodium

3. Sori acrostichoid, nonindusiate

4. Apices of the laminae conform, similar in shape to the lateral pinnae

Mickelia

4. Apices of the laminae gradually tapered and pinnatifid

5. Veins areolate; plants terrestrial. Bolbitis

5. Veins free; plants hemiepiphytic Polybotrya

1. Sterile and fertile leaves monomorphic

6. Laminae 1-pinnate-pinnatifid Ctenitis

6. Laminae 2-pinnate-pinnatifid to 4-pinnate-pinnatifid

7. Laminae 3 or 4-pinnate-pinnatifid; rachis buds present distally Parapolystichum

7. Laminae 2 or 3-pinnate-pinnatifid; rachis buds absent

8. Laminae narrowly lanceolate; pinnules catadromic Dryopteris

8. Laminae deltate; pinnules anadromic . Arachniodes

Arachniodes Blume, Enum. P1. Javae 2: 241-242. 1828.

Characterized by rhizomes creeping; leaves monomorphic; petioles with more than three vascular bundles; laminae broadly deltate or pentagonal, 2- to 5-pinnate; medial pinnae prolonged acroscopically, the basal basiscopic side cuneate; basal pinnules anadromically arranged, stalked; rachises and costae with adaxial grooves glabrous, without proliferous buds; veins free; sori round; indusium orbicular-reniform.
Pantropical, mostly Asian, ca. 60 species, 2 in Acre.

1. Laminae chartaceous, 3-pinnate-pinnatisect at base, discolor (adaxially dark green and abaxially light green); segments conspicuously dentateserrate ...... A. macrostegia

1. Laminae subcoriaceous, 2-pinnate-pinnatisect at base; segments entire Arachniodes sp.

Arachniodes macrostegia (Hook.) R.M. Tryon \& D.S. Conant, Acta Amazon. 5(1): 29. 1975. Nephrodium macrostegium Hook., Sp. Fil. 4: 148. 1862.

Figures: $14 \mathrm{D}-\mathrm{F}$

Habit/Habitat: Herb; terrestrial, in terra firme forest.

Material examined: Cruzeiro do Sul, R. Goldenberg et al. 1013 (NY), J. Prado et al. 1157 (SP, UFACPZ), J. Prado et al. 1287 (SP, UFACPZ).

World Distribution: Venezuela, Peru, and N Brazil.

Characterized by chartaceous, 3-pinnate-pinnatisect laminae that are dark green adaxially and light green abaxially, and segments conspicuously dentate-serrate.

\section{Arachniodes sp.}

Figures: $14 \mathrm{~A}-\mathrm{C}$

Habit/Habitat: Herb; terrestrial, on sandy soil in Campinarana (open vegetation).

Material examined: Cruzeiro do Sul, J. Prado et al. 1181 (SP, UFACPZ).

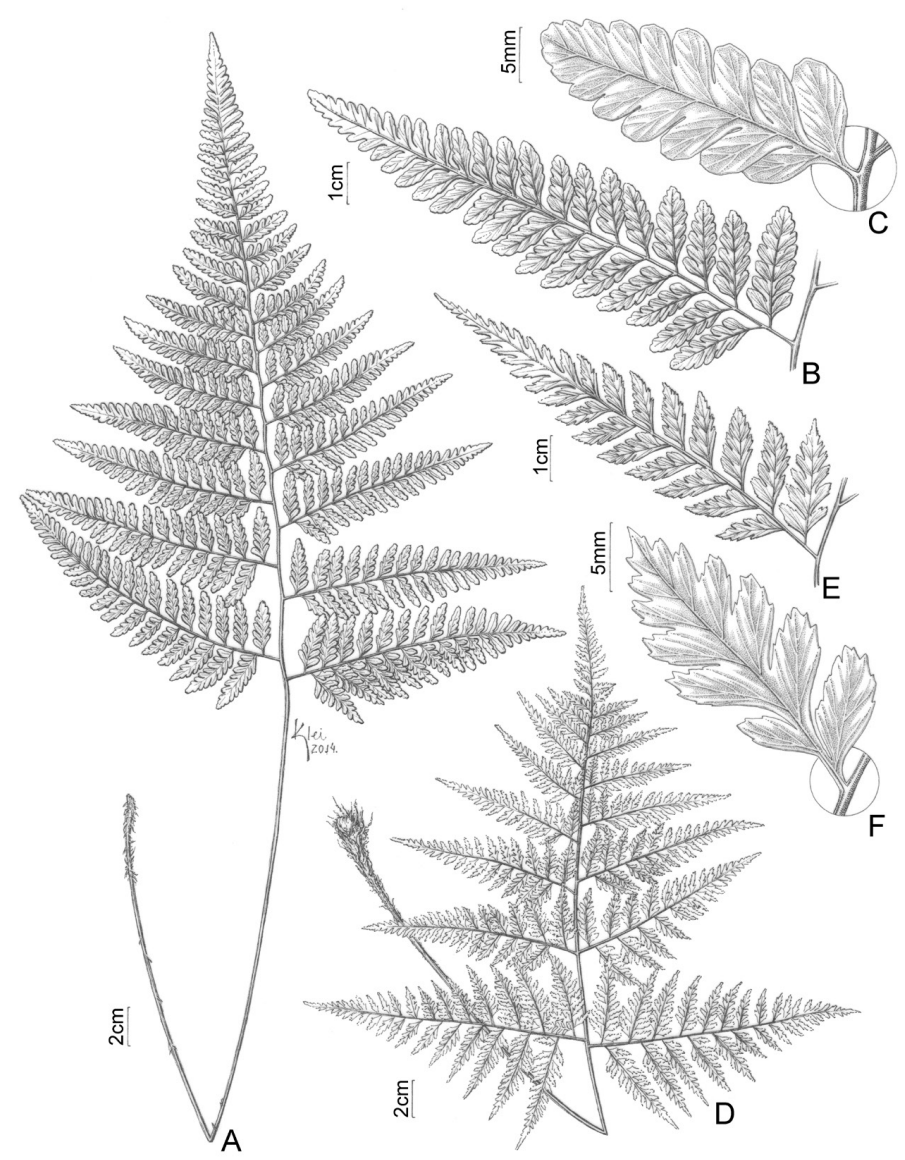

Figure 14. A-C. Arachniodes sp. (Prado et al. 1181, SP). A. Habit. B. Sterile pinna. C. Venation of the sterile frond. D-F. Arachniodes macrostegia (Prado et al. 1287, SP). D. Habit. E. Sterile pinna. F. Venation of the sterile frond. 
World Distribution: N South America (Acre).

Characterized by subcoriaceous, 2-pinnate-pinnatisect laminae, obtuse pinnules, and entire segments. This collection Prado et al. 1181 was incorrectly identified as Rumohra adiantiformis (G. Forst) Ching in Prado \& Moran (2009). The material cited here represents an undescribed species being studied by R. Moran and P. Labiak.

Bolbitis Schott, Gen. Fil. tab. 14. 1834.

Characterized by areolate veins (with or without included veinlets in the areoles), dimorphic sterile and fertile leaves, and acrostichoid sori. The rhizomes in cross-section exhibit an elongate ventral meristele and several small, circular ones dorsally. Buds absent, or if present, then found near the apices of the leaves or pinnae. Bolbitis is most diverse in Asia.

Pantropical; ca. 80 species; 12 species the Neotropics (Moran et al. 2010a), 2 in Acre.

1. Rhizomes short-creeping; pinnae $8-15$ pairs in the sterile laminae; areoles with included veinlets

B. serratifolia

1. Rhizomes long-creeping; pinnae $2-5$ pairs in the sterile laminae; areoles without included veinlets B. aliena

Bolbitis aliena (Sw.) Alston, Bull. Misc. Inform. Kew. 1932(7): 310. 1932. Acrostichum alienum Sw., J. Bot. (Schrader) 1800(2): 13. 1801[1802].

Figures: 15A, B

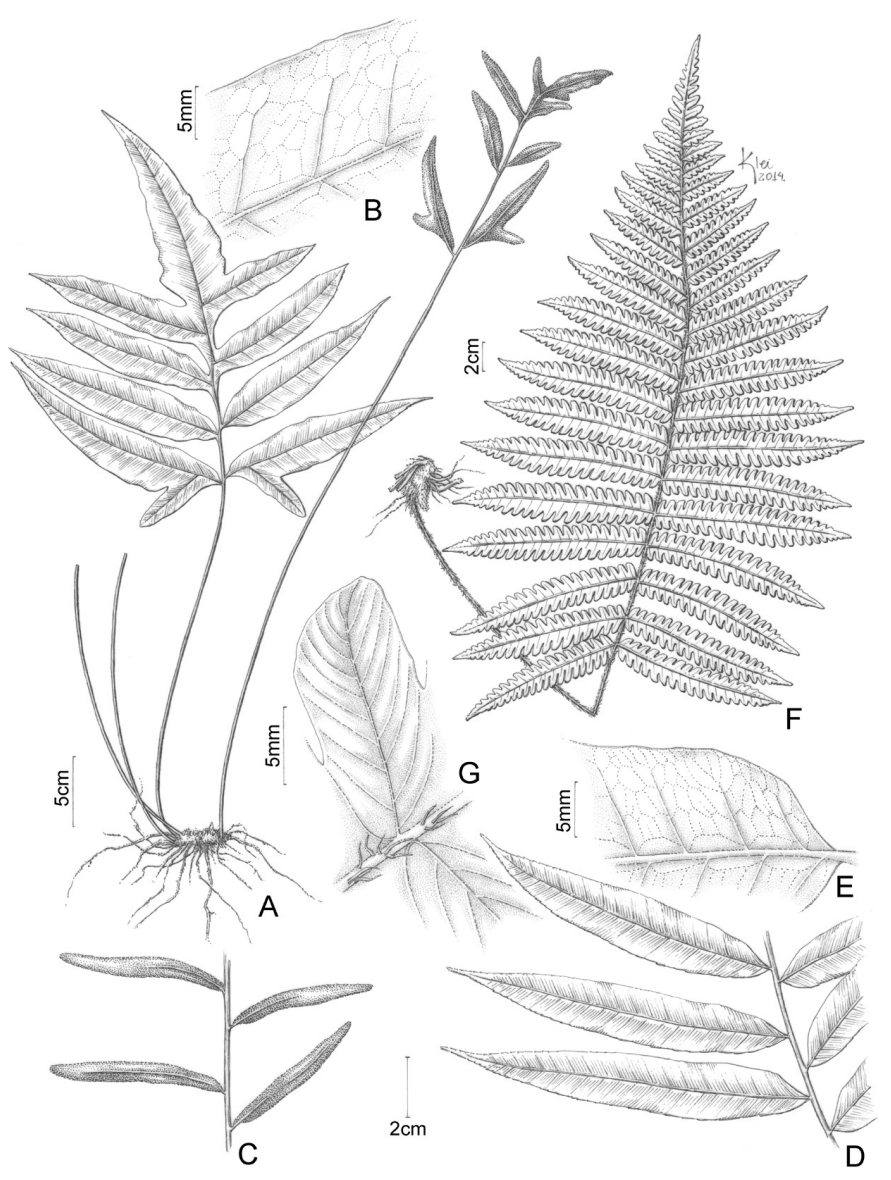

Figure 15. A, B. Bolbitis aliena (from Rondônia, [Porto Velho], Taylor 5047, NY) A. Habit. B. Venation of the sterile lamina. C-E. Bolbitis serratifolia (Silveira et al. 4128 , NY). C. Sterile pinnae. D. Fertile pinnae. E. Venation of the sterile frond F, G. Ctenitis refulgens (Prado et al. 1343, SP). F. Habit. G. Venation of the sterile frond.
Habit/Habitat: Herb; terrestrial in forest.

Material examined: Acrelândia, T.B. Croat 85889 (NY).

World Distribution: Mexico, Antilles, Mesoamerica, and N South America to Bolivia.

Characterized by the proximal pinnae with a greatly enlarged basiscopic, basal lobe and areoles without included veinlets.

Bolbitis serratifolia (Mert. ex Kaulf.) Schott, Gen. Fil. tab. 13. 1834[1835]. Acrostichum serratifolium Mert. ex Kaulf., Enum. Filic. 66. 1824.

Figures: $15 \mathrm{C}-\mathrm{E}$

Habit/Habitat: Herb; terrestrial in bamboo forest.

Material examined: Sena Madureira, M. Silveira et al. 4128 (NY).

World Distribution: Mexico, Mesoamerica, and South America.

Characterized by short-creeping rhizomes and sterile lamina with $8-15$ pinna pairs. The proximal pinna pair is entire, each without an enlarged basal lobe

Ctenitis (C. Chr.) C. Chr., Man. Pteridol. 544. 1938. Dryopteris subg. Ctenitis C. Chr., Biol. Arb. Til. Eug. Warming 77. 1911.

Characterized by distinctive hairs, called Ctenitis hairs, on the adaxial surface of the laminar axes. These hairs are short $(0.2-0.5 \mathrm{~mm}$ long), reddish, several-celled, and appear jointed because the cells twist at right angles to each other upon drying. The sori are round and may be either indusiate or exindusiate.

Pantropical; ca. 125 species, 1 in Acre.

Ctenitis refulgens (Klotzsch ex Mett.) C. Chr. ex Vareschi, Fl. Venezuela 1: 404. 1969. Phegopteris refulgens Klotzsch ex Mett., Ann. Sci. Nat., Bot., sér. 5, 2: 240. 1864.

Figures: $15 \mathrm{~F}, \mathrm{G}$

Habit/Habitat: Herb; terrestrial, in forest.

Material examined: Cruzeiro do Sul, J. Prado et al. 1343 (SP, UFACPZ).

World Distribution: Mexico, Mesoamerica, and N South America to Bolivia.

Characterized by 1-pinnate-pinnatifid laminae, indument of "Ctenitis hairs" on the axes and veins, 2 or 3 pairs of proximal pinnae slightly deflexed, and scaly petioles and rachises.

Cyclodium C. Presl, Tent. Pterid. 85, tab. 2, fig. 20-21. 1836.

Characterized by rhizomes creeping, scaly; leaves monomorphic or slightly dimorphic; laminae pinnate to 2-pinnate-pinnatifid, glabrous or nearly so, anadromous, the apex pinnatifid, abruptly tapered or with a terminal pinna similar in form to the lateral ones; costae abaxially with uniseriate hairs, reddish or brownish, appressed; veins free or anastomosing, ending at the margins, not enlarged at tips; sori round; indusia round, peltate or attached at a narrow sinus, sometimes deciduous. A revision of the genus was published by Smith (1986).

Neotropical; 10 species, 2 in Acre.

1. Veins free; sterile and fertile leaves monomorphic ..... C. guianense

1. Veins regularly anastomosing; sterile and fertile leaves dimorphic C. meniscioides var. meniscioides

Cyclodium guianense (Klotzsch) van der Werff ex L.D. Gómez, Phytologia 60(5): 371. 1986. Aspidium guianense Klotzsch, Linnaea 20: 364.1847.

Figures: 16A, B

Habit/Habitat: Herb; terrestrial, in terra firme forest.

Material examined: Cruzeiro do Sul, J. Prado et al. 1342 (SP, UFACPZ); Without locality, J. Jangoux et al. 85-034 (NY).

World Distribution: N South America to Bolivia.

Characterized by the monomorphic sterile and fertile leaves, subcoriaceous laminae with pinnatifid apices, and free veins. 
Cyclodium meniscioides (Willd.) C. Presl var. meniscioides, Tent. Pterid. 85. 1836. Aspidium meniscioides Willd., Sp. Pl., ed. 4 [Willdenow] 5: 218.1810.

Figures: $16 \mathrm{C}-\mathrm{E}$

Habit/Habitat: Herb; terrestrial or sometimes a low-climber on trunks, in terra firme forest.

Material examined: Cruzeiro do Sul, J. Prado et al. 1330 (SP, UFACPZ); Mâncio Lima, J. Prado et al. 1226 (SP, UFACPZ), J. Prado et al. 1228 (SP, UFACPZ).

World Distribution: N South America to Bolivia.

Characterized by the strongly dimorphic sterile and fertile leaves, pinnae 5-7 $\mathrm{cm}$ apart, anastomosing veins, and sterile pinnae up to $8 \mathrm{~cm}$ wide.

Dryopteris Adans., Fam. P1. 2: 20. 1763.

No one single character distinguishes this genus; it must be identified by the combination of several characters. Dryopteris belongs to Eupolypods I, a group that has three or more vascular bundles in the petioles, usually with 2 adaxial ones enlarged. Helpful characters are compact, erect or ascending, scaly rhizomes; monomorphic sterile and fertile leaves; laminae 2- to 3-pinnate-pinnatifid, less commonly 1-pinnate-pinnatifid; veins free; sori round; indusia usually present, attached at the base of a narrow sinus, reniform or orbicular.

The three species occurring in Brazil were revised by Prado et al. (2014).

Cosmopolitan; 400 species, 1 in Acre.

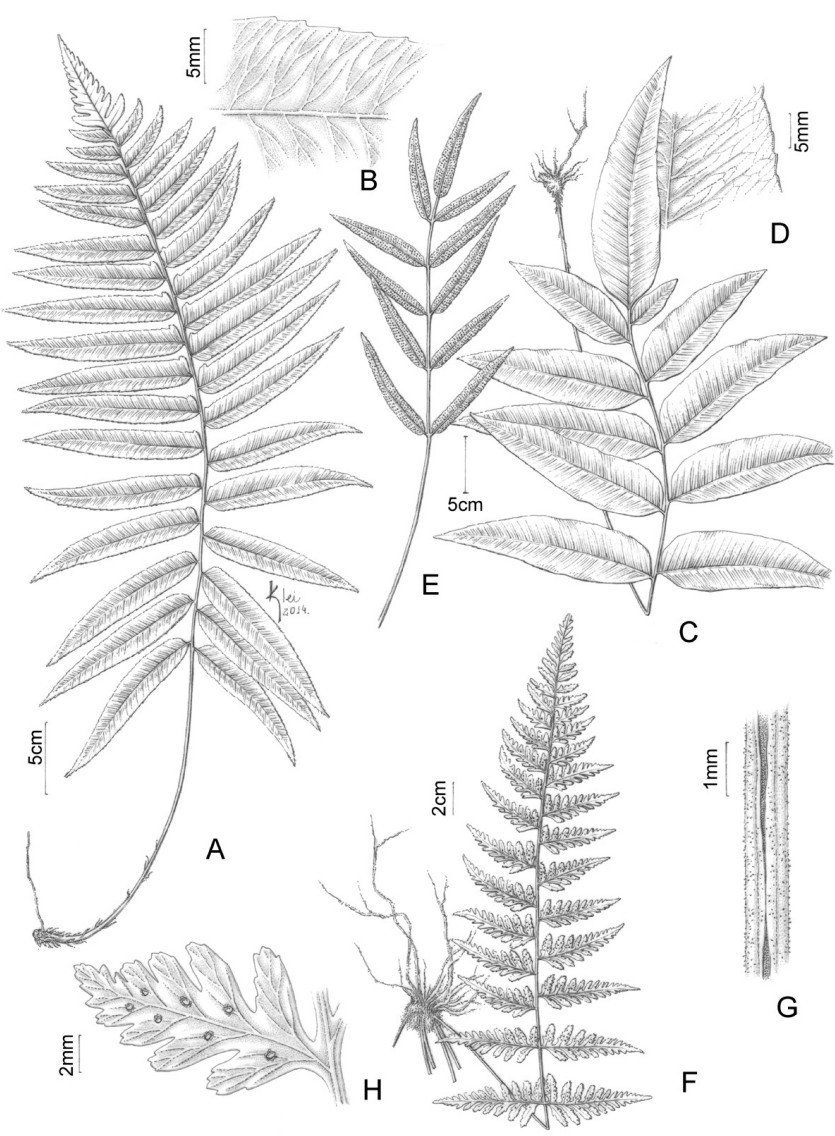

Figure 16. A, B. Cyclodium guianense (Prado et al. 1342, SP). A. Sterile frond. B. Venation of the sterile frond. C-E. Cyclodium meniscioides var. meniscioides (Prado et al. 1226, SP). C. Habit. D. Venation of the sterile frond. E. Fertile pinnae. F-H. Dryopteris patula (Daly et al. 8117, NY). F. Habit. G. Rachis adaxially. H. Fertile segments.
Dryopteris patula (Sw.) Underw., Native Ferns (ed. 4) 117. 1893. Aspidium patulum Sw., Kongl. Vetensk. Acad. Handl. 1817(1): 64. 1817.

Figures: $16 \mathrm{~F}-\mathrm{H}$

Habit/Habitat: Herb; terrestrial in moist forest on terra firme, canopy discontinuous.

Material examined: Plácido de Castro, C. Figueiredo \& I. Riveiro 560 (NY); Sena Madureira, D.C. Daly et al. 8117 (NY).

World Distribution: S Mexico, Antilles, Mesoamerica, and tropical South America.

Characterized by pinna-rachises (costae) adaxially lacking perpendicular wings, erect rhizomes, segments with narrower sinuses, and proximal pinnae that tend to equal in size the next distal pair. Several capitate-glandular hairs are present on the laminar tissue, rachises, and veins adaxially.

Elaphoglossum Schott ex. J. Sm., J. Bot. (Hooker) 4: 148. 1842, nom. et typ. cons.

Nearly all species have simple and entire leaves, strong sterile-fertile leaf dimorphy, free veins, and acrostichoid sori. All Acre species have phyllopodia. Compared to the sterile leaves, the fertile ones are narrower and longer petiolate. The largest genus of Dryopteridaceae.

Pantropical; ca. 600 species, 8 in Acre.

1. Lamina abaxially with resinous dots

E. tantalinum

1. Lamina abaxially without resinous dots

2. Petioles absent; laminar apices cuspidate; lamina margins thickened.

E. styriacum

2. Petioles present; laminar apices acute, long-acuminate or obtuse; lamina margins not thickened

3. Sterile laminae densely scaly on both surfaces, apices sometimes viviparous

E. plumosum

3. Sterile laminae sparsely scaly or hairy on both surfaces, apices not viviparous

4. Sterile leaves to $1.2 \mathrm{~cm}$ wide

E. glabellum

4. Sterile leaves $2-8.5 \mathrm{~cm}$ wide

5. Laminar margins and costae with patent, entire, filiform scales

E. raywaense

5. Laminar margins and costae glabrous or with appressed, lanceolate, ciliate, ovate scales

6. Leaves thin, narrowly elliptic, nearly glabrous on the laminae and petioles, sometimes with a few dissected scales on the costa and petiole

E. flaccidum

6. Leaves chartaceous or coriaceous, broadly elliptic to oblanceolate; conspicuously scaly on the costa and laminar margins

7. Petioles $12-18 \mathrm{~cm}$ long; laminae broadly elliptic, chartaceous E. discolor

7. Petioles 1-3 cm long; laminae oblanceolate, coriaceous .

E. luridum

Elaphoglossum discolor (Kuhn) C. Chr., Index Filic. 306. 1905. Acrostichum discolor Kuhn, Linnaea 36: 53. 1869.

Figures: $17 \mathrm{~A}-\mathrm{E}$

Habit/Habitat: Herb; terrestrial or epipetric, in Campina.

Material examined: Cruzeiro do Sul, D.C. Daly et al. 10607 (NY), J. Prado et al. 1159 (SP, UFACPZ). J. Prado et al. 1170 (SP, UFACPZ), 
J. Prado et al. 1188 (SP, UFACPZ), J. Prado et al. 1284 (SP, UFACPZ), J. Prado et al. 1322 (SP, UFACPZ), J. Prado et al. 1324 (SP, UFACPZ), J. Prado et al. 1329 (UFACPZ), J. Prado et al. 1388 (SP, UFACPZ); Mâncio Lima, C. Ferreira et al. 10953 (MO), J. Prado et al. 1223 (SP, UFACPZ).

World Distribution: N South America.

Characterized by rhizome scales orange or rarely dull brown, broadly elliptic sterile leaves with linear dissected orange scales abaxially.

Elaphoglossum flaccidum (Fée) T. Moore, Index Filic. 356. 1862 Acrostichum flaccidum Fée, Mém. Foug. 2: 35, tab. 7, fig. 2. 1845.

Figures: $17 \mathrm{~F}, \mathrm{G}$

Habit/Habitat: Herb; epiphyte, in terra firme forest.

Material examined: Rodrigues Alves, J. Prado et al. 1266 (SP, UFACPZ); Xapuri, Silva et al.186 (CEN, SP).

World Distribution: Antilles and N South America to Bolivia.

Characterized by blackish rhizome scales, short or nearly absent petioles, thin and narrowly elliptic laminae, and nearly glabrous laminae and petioles (sometimes a few dissected scales are present on the costa and petiole). The vein tips are often expanded laterally and sometimes united into a submarginal connecting strand.

Elaphoglossum glabellum J. Sm., London J. Bot. 1: 197. 1842.

Habit/Habitat: Herb; epiphyte, in terra firme forest.

Material examined: Cruzeiro do Sul, J. Prado et al. 1297 (SP, UFACPZ).

World Distribution: Mexico, Antilles, Mesoamerica, and N South America to Bolivia.

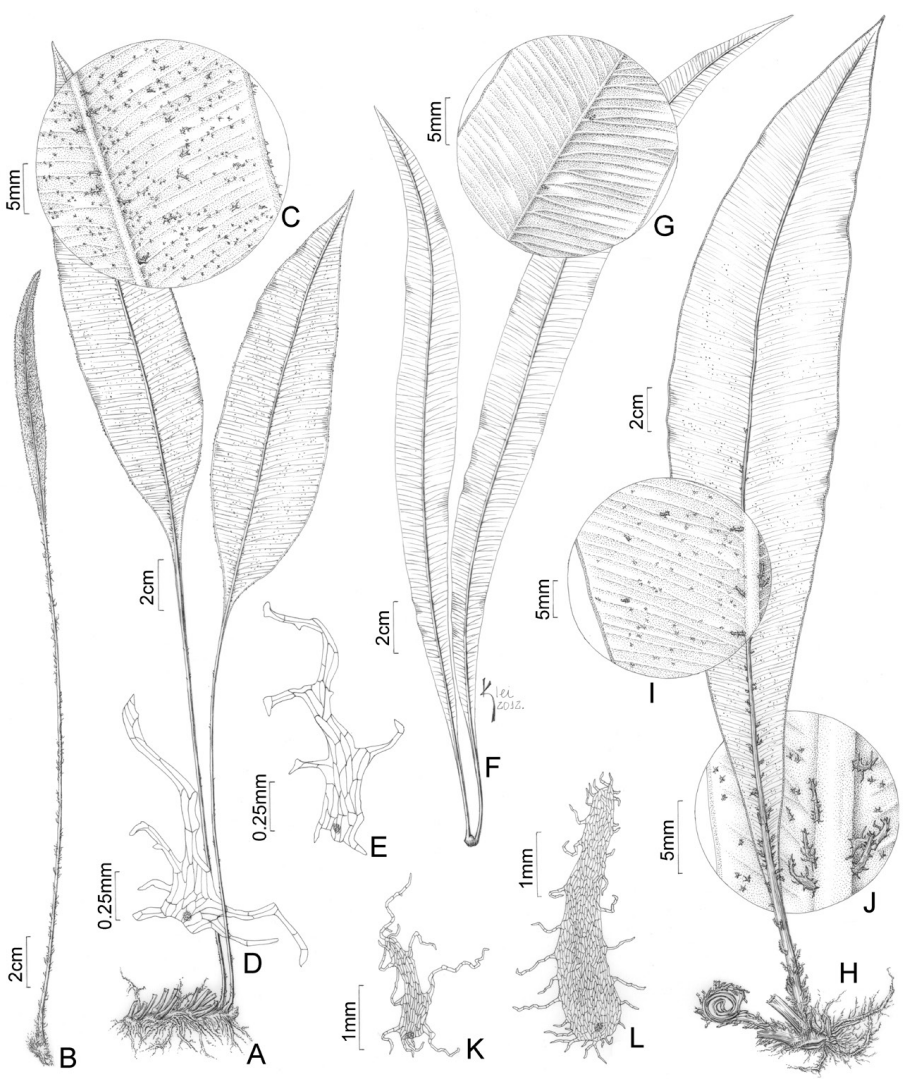

Figure 17. A-E. Elaphoglossum discolor. A. Habit (Prado et al. 1223, SP). B. Fertile frond (Prado et al. 1284, SP). C. Abaxial laminar surface. D, E. Abaxial lamina scales (C-E. Prado et al. 1223, SP). F, G. Elaphoglossum flaccidum (Prado et al. 1266, SP). F. Sterile fronds. G. Abaxial laminar surface. H-L. Elaphoglossum luridum (Prado et al. 1198, SP). H. Habit. I. Abaxial laminar surface. J. Costa abaxially with scales. K, L. Abaxial laminar scales.
Characterized by coriaceous, linear laminae only $0.5-1.5 \mathrm{~cm}$ wide. The rhizome scales are distinctive by the body of the scales either shiny black or dark brown, with a distinct lighter brown border.

Elaphoglossum luridum (Fée) Christ, Neue Denkschr. Allg. Schweiz. Ges. Gesammten Naturwiss. 36(1): 33. 1899. Acrostichum luridum Fée, Mém. Foug. 2: 35, tab. 19, fig. 1. 1845.

Figures: $17 \mathrm{H}-\mathrm{L}$

Habit/Habitat: Herb; epiphyte, in terra firme forest.

Material examined: Cruzeiro do Sul, J. Prado et al. 1152 (SP, UFACPZ), J. Prado et al. 1174 (SP, UFACPZ), J. Prado et al. 1198 (SP, UFACPZ), J. Prado et al. 1310 (SP, UFACPZ), J. Prado et al. 1327 (SP, UFACPZ); Mâncio Lima, J. Prado et al. 1219 (SP, UFACPZ), J. Prado et al. 1220 (SP, UFACPZ); Rodrigues Alves, J. Prado et al. 1238 (SP, UFACPZ), J. Prado et al. 1241 (SP, UFACPZ), J. Prado et al. 1260 (SP, UFACPZ), J. Prado et al. 1281 (SP, UFACPZ).

World Distribution: Antilles, Mesoamerica, and N South America to Bolivia.

Characterized by coriaceous, oblanceolate laminae $3.5-8.5 \mathrm{~cm}$ wide, and scales on the costae and abaxial surface of the laminae conspicuous, dissected, and blackish.

Elaphoglossum plumosum (Fée) T. Moore, Index Filic. 364. 1862. Acrostichum plumosum Fée, Mém. Foug., Hist. Acrostich. 2: 54, tab. 20, fig. 1.1845.

Figures: $18 \mathrm{~A}-\mathrm{D}$

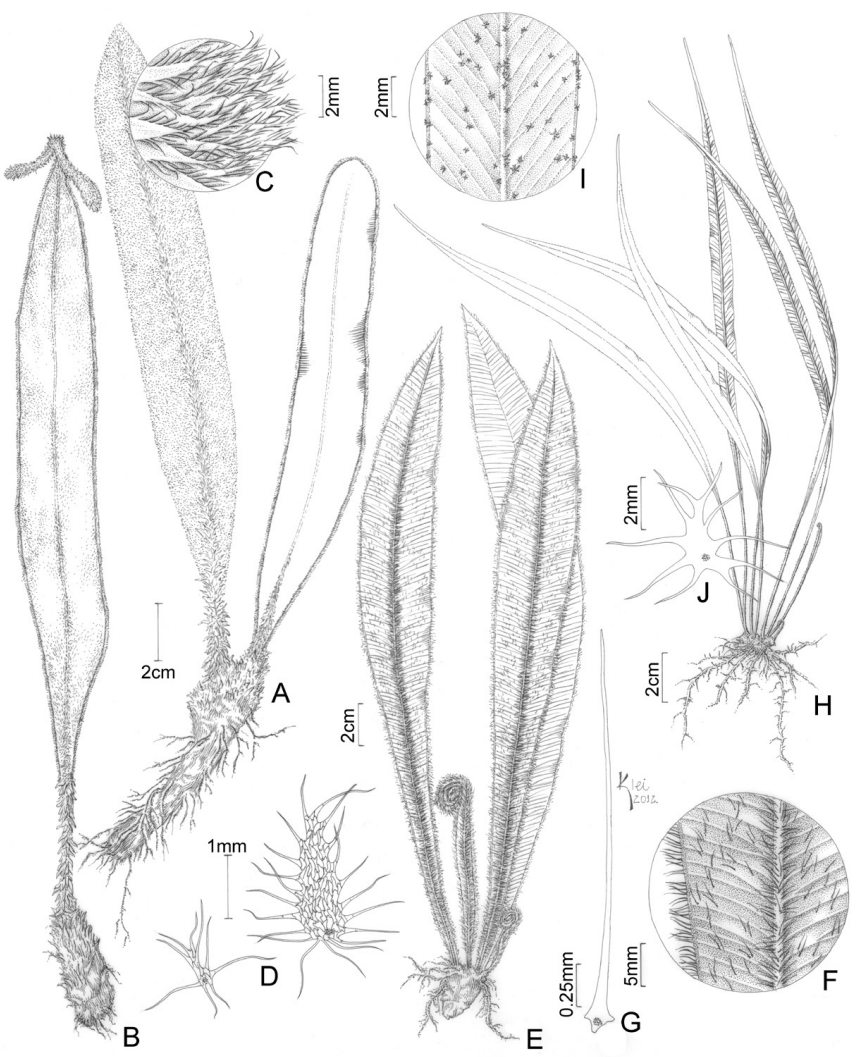

Figure 18. A-D. Elaphoglossum plumosum. A. Habit (Prado et al. 1154, SP). B. Frond with a gemma (Prado et al. 1221, SP). C. Abaxial laminar surface (Prado et al. 1154, SP). D. Adaxial laminar scales (Prado et al. 1221, SP). E-G. Elaphoglossum raywaense (Prado et al. 1314, SP). E. Habit. F. Abaxial laminar surface. G. Abaxial lamina scale. H-J. Elaphoglossum tantalinum (Prado et al 1384, SP). H. Habit. I. Abaxial laminar surface. J. Abaxial laminar scale. 
Habit/Habitat: Herb; epiphyte, in terra firme forest.

Material examined: Cruzeiro do Sul, J. Prado et al. 1154 (SP, UFACPZ), J. Prado et al. 1285 (UFACPZ); Mâncio Lima, J. Prado et al. 1221 (SP, UFACPZ), J. Prado et al. 1390 (SP, UFACPZ).

World Distribution: N South America to Bolivia.

Characterized by petioles and sterile laminae densely scaly on both surfaces, the scales broadly lanceolate or ovate, long-ciliate, and orange to light brown. Apex of the laminae sometimes viviparous. The laminae are so scaly that the surfaces are completely hidden.

Elaphoglossum raywaense (Jenman) Alston, Bol. Soc. Brot., sér. 2, 32: 24. 1958. Acrostichum raywaense Jenman, Ferns Brit. W. Ind. 341. 1909.

Figures: $18 \mathrm{E}-\mathrm{G}$

Habit/Habitat: Herb; epiphyte, in terra firme forest.

Material examined: Cruzeiro do Sul, J. Prado et al. 1314 (SP, UFACPZ); Mâncio Lima, D.C. Daly et al. 8948 (NY, UFACPZ).

World Distribution: N South America to Bolivia.

The only species in Acre with subulate laminar scales (i.e., scales that are enrolled basally with hairlike tips distally). Also distinct by sessile leaves, narrowly oblanceolate laminae, and orange scales on the rhizomes and laminae.

Elaphoglossum styriacum Mickel, Brittonia 39(3): 326, fig. 4I-K. 1987.

Habit/Habitat: Herb; epiphyte, in terra firme forest.

Material examined: Cruzeiro do Sul, J. Prado et al. 1381 (SP, UFACPZ).

World Distribution: N South America.

Characterized by laminae strongly coriaceous and cuspidate, with the margins conspicuously thickened.

Elaphoglossum tantalinum Mickel, Brittonia 39(3): 328, fig. 2G, H. 1987.

Figures: $18 \mathrm{H}-\mathrm{J}$

Habit/Habitat: Herb; epiphyte, in terra firme forest.

Material examined: Cruzeiro do Sul, J. Prado et al. 1179 (SP, UFACPZ), J. Prado et al. 1321 (SP, UFACPZ), J. Prado et al. 1384 (SP, UFACPZ); Mâncio Lima, T.E. Almeida \& A. Salino 2620 (BHCB).

World Distribution: N South America.

Characterized by the combination of two characters on the sterile laminae abaxially: conspicuous resinous dots and ciliate scales. In contrast, the laminae adaxially has scattered round ciliate scales or stellate hairs. The ciliate scales are also present on the laminar margins.

Almeida \& Salino 2620 (BHCB) was cited by Almeida \& Salino (2015) as Elaphlogossum stenophyllum (Sodiro) Diels.

Mickelia R.C. Moran et al., Brittonia 62(4): 338-339. 2010.

Mickelia resembles Bolbitis by anastomosing veins, sterile-fertile leaf dimorphy, and acrostichoid sori. In those species of Mickelia that bear buds on the leaves, the buds occur at the pinna bases near the rachis; in contrast, in Bolbitis they occur near the lamina or pinna apices. The two genera differ somewhat in growth habit: Bolbitis is always terrestrial; however, Mickelia may be either terrestrial or a terrestrial root-climber (i.e., starting on the ground, then climbing, without losing the connection to the soil). The latter growth habit occurs in two Acre species: M. nicotianifolia and $M$. bernoullii. Fertile leaves are produced only on the climbing portion of the rhizome.

Neotropical; 10 species (Moran et al. 2010a, b), 5 in Acre.

1. Only 1 pair of pinnae; buds present distally on the lamina M. oligarchica

1. 2-19 pairs of lateral pinnae; buds absent on the lamina distally
2. 2-4 pairs of lateral pinnae M. nicotianifolia

2. 8-19 pairs of lateral pinnae

3. Areoles with free included veinlets M. bernoullii

3. Areoles without free included veins

4. Margins of the sterile pinnae serrate M. guianensis

4. Margins of the sterile pinnae crenate M. lindigii

Mickelia bernoullii (Kuhn ex Christ) R.C. Moran et al., Brittonia 62(4): 342, fig. 1A, 2. 2010. Acrostichum bernoullii Kuhn ex Christ, Bull. Soc. Bot. Belgique 35(1): 244. 1896.

Figures: $19 \mathrm{~A}-\mathrm{C}$

Habit/Habitat: Herb; terrestrial, in terra firme forest.

Material examined: Jordão, F.A. Michelangeli et al. 1321 (NY).

World Distribution: Mexico, Mesoamerica, and N South America to Bolivia.

Characterized by 8-19 pairs of pinnae, these elliptic, 19-20 $\times 4 \mathrm{~cm}$, rounded at the base, margins of the sterile ones entire, leaves without buds distally, and areoles with included veinlets.

Mickelia guianensis (Aubl.) R.C. Moran et al., Brittonia 62(4): 345. 2010. Polypodium guianense Aubl., Hist. Pl. Guiane 962. 1775.

Figures: 19D, E

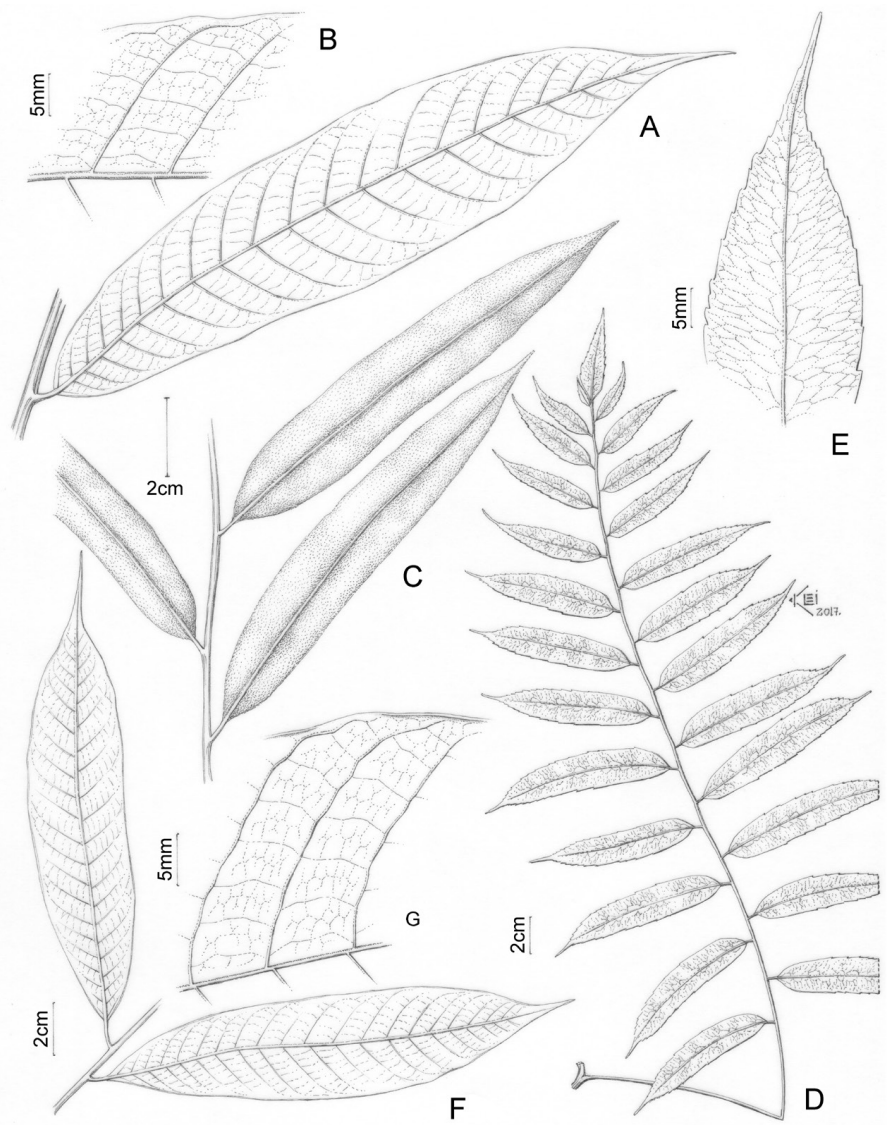

Figure 19. A-C. Mickelia bernoullii (Michelangeli et al. 1321, NY). A. Sterile pinna. B. Venation of the sterile pinna. C. Fertile pinnae. D, E. Mickelia guianensis (Prado et al. 1292, SP). D. Habit. E. Venation of the sterile frond. F, G. Mickelia nicotianifolia (Prado et al. 1395, SP). F. Sterile pinnae. G. Venation of the sterile pinna. 
Habit/Habitat: Herb; terrestrial root-climber, in terra firme forest.

Material examined: Brasiléia, D.C. Daly et al. 6757 (NY, UFACPZ), D.C. Daly et al. 6786 (NY), D.C. Daly et al. 11882 (NY); M. Silveira et al. 1662 (NY); Cruzeiro do Sul, J. Prado et al. 1292 (SP, UFACPZ); Mâncio Lima, D.C. Daly et al. 11623 (NY); Marechal Thaumaturgo, D.C. Daly et al. 7430 (NY, UFACPZ); Rodrigues Alves, J. Prado et al. 1252 (SP, UFACPZ), J. Prado et al. 1278 (SP, UFACPZ); Xapuri, L.G. Lohmann \& E.C. de Oliveira 590 (NY).

World Distribution: Greater Antilles (except Jamaica) and tropical South America.

Characterized by long-creeping rhizomes, 8-13 pairs of pinnae, these oblong, 4-11 $\times 1-2 \mathrm{~cm}$, cuneate basally, margins of the sterile ones serrate, leaves without buds distally, and areoles without included veinlets.

Mickelia lindigii (Mett.) R.C. Moran et al., Brittonia 62(4): 347. 2010. Chrysodium lindigii Mett., Ann. Sci. Nat., Bot., sér. 5, 2: 205. 1864.

Figures: $20 \mathrm{~A}-\mathrm{C}$

Habit/Habitat: Herb; terrestrial root-climber, in open forest on undulating terrain, except for baixios (waterlogged low-lying areas).

Material examined: Mâncio Lima, G.T. Prance et al. 12069A (NY); Marechal Thaumaturgo, D.C. Daly et al. 10252 (NY).

World Distribution: Mesoamerica and N South America to Bolivia.

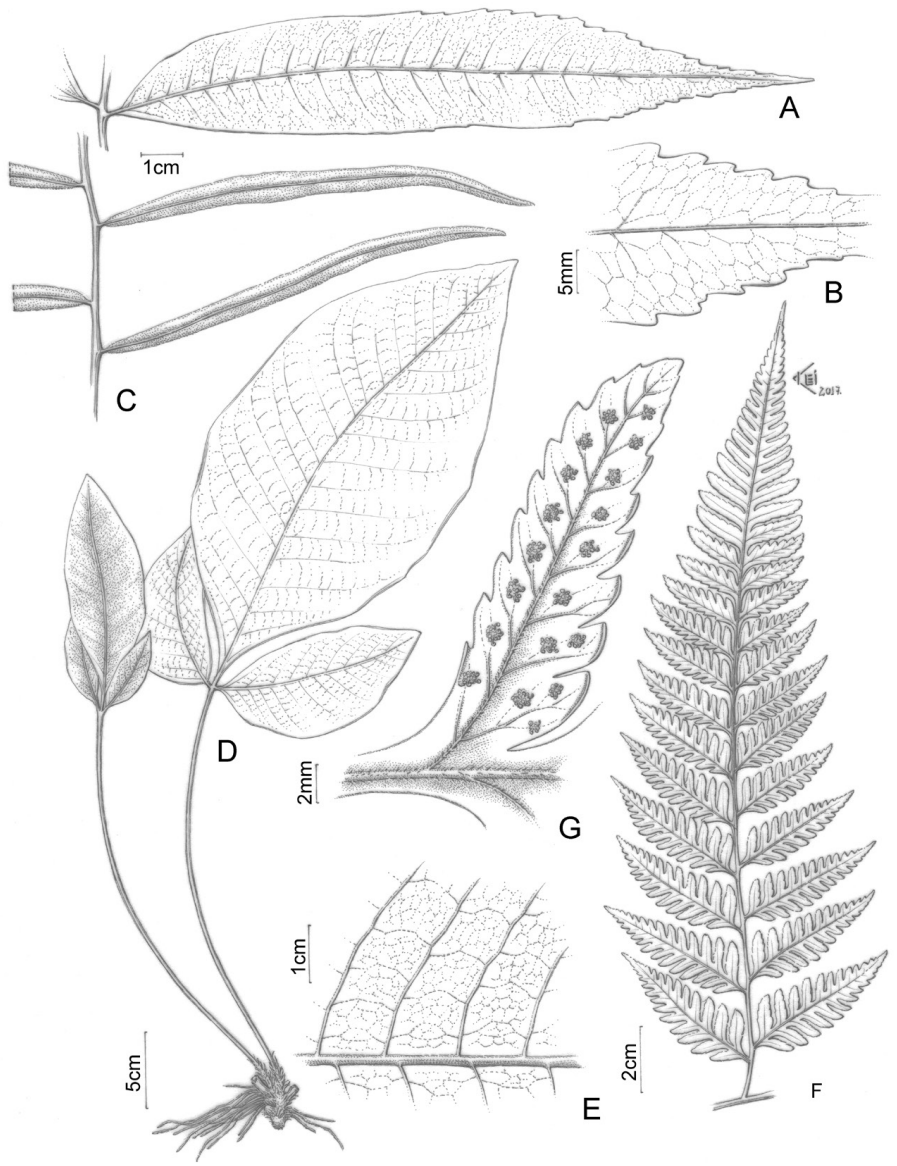

Figure 20. A-C. Mickelia lindigii (Daly et al. 10252, NY). A. Sterile pinna B. Venation of the sterile pinna. C. Fertile pinna. D, E. Mickelia oligarchica (Silveira et al. $1361, \mathrm{NY})$. D. Habit. E. Venation of the sterile frond. F, G. Parapolystichum effusum var. divergens (Daly et al. 11421, NY). F. Sterile pinna. G. Venation and sorus.
Characterized by 10-19 pairs of pinnae, these oblong, $13-19 \times 2-2.5 \mathrm{~cm}$, margins of the sterile ones crenate, base cuneate, laminae without buds distally, areoles without free included veinlets.

Mickelia nicotianifolia (Sw.) R.C. Moran et al., Brittonia 62(4): 347. 2010. Acrostichum nicotianifolium Sw., Syn. Fil. 13: 199. 1806.

Figures: 19F, G

Habit/Habitat: Herb; terrestrial root-climber, in open forest on undulating terrain, except for baixios (waterlogged low-lying areas).

Material examined: Bujari, W.R. Anderson 12122 (NY), D.C. Daly et al. 9477 (NY); Cruzeiro do Sul, J. Prado et al. 1349 (UFACPZ); Manoel Urbano, D.C. Daly et al. 9128 (NY), D.C. Daly et al. 11413 (NY); Porto Valter, P.J.M. Maas et al. P13292 (NY); Rio Branco, J. Prado et al. 1395 (SP); Sena Madureira, D.C. Daly et al. 8072 (NY).

World Distribution: Antilles, Mesoamerica, and N South America to Bolivia.

Characterized by 2-4 pairs of pinnae, these elliptic, $17-20 \times 3.5-4 \mathrm{~cm}$, base cuneate, margins of the sterile ones entire, leaves without buds, venation areolate with free included veinlets. This species is a terrestrial root-climber. Non-climbing plants have slender long-creeping rhizomes and simple, entire leaves.

Mickelia oligarchica (Baker) R.C. Moran et al., Brittonia 62(4): 350. 2010. Acrostichum oligarchicum Baker, Syn. Fil. 418. 1868.

Figures: 20D, E

Habit/Habitat: Herb; terrestrial, in forest.

Material examined: Mâncio Lima, M. Silveira et al. 1361 (NY).

World Distribution: Mesoamerica and N South America to Bolivia.

Characterized by ternate laminae with buds in the axils of the basal pinnae. The apical pinna is quite large $(33 \times 17 \mathrm{~cm})$, and the lateral pinnae are broadly elliptic $(10-13 \times 4-6 \mathrm{~cm})$, with broadly rounded bases. The veins are areolate with free included veinlets.

The laminae are held nearly horizontal to the ground and accumulate fallen organic matter between the two lateral pinnae and the terminal leaf segment. The buds germinate and grow in this accumulated organic matter. As the leaf senesces with age, the buds remain attached and are lowered to the ground where they take root in the soil. By this means of vegetative reproduction, the plants often form colonies.

Parapolystichum (Keyserl.) Ching, Sunyatsenia 5: 239. 1940. Polystichum sect. Parapolystichum Keyserl., Polyp. Herb. Bunge 11, 45. 1873.

Resembling Lastreopsis but distinguished by the presence of a bud distally along the rachis. Further characterized by rhizomes short- to long-creeping, scaly; sterile and fertile leaves monomorphic; petioles with four or more vascular bundles; laminae 3-4-pinnate-pinnatifid, lanceolate, deltate, or pentagonal, the lower pinnae enlarged basiscopically; pinnules anadromic or catadromic; rachises with 2 prominent ridges adaxially, these continuous with the thickened margins of the ultimate segments; costae raised (not grooved), hairy adaxially with $0.1-0.3 \mathrm{~mm}$ long, multicellular hairs, costae, and costules scaly abaxially, hairy adaxially; glandular hairs often present on the lower surface of the lamina, these cylindrical, oblong appressed, bright yellow to orange-red; sori round.

Pantropical; 28 species (Labiak et al. 2014a, b), 1 in Acre.

Parapolystichum effusum (Sw.) Ching var. divergens (Willd. ex Schkuhr) Abbiatti, Revista Mus La Plata, Secc. Bot. 9: 19. 1958. Polypodium divergens Willd. ex Schkuhr, 24. K1. Linn. Pfl.-Syst. 1: 27, tab. 26b. 1805.

Figures: 1F, 20F, G

Habit/Habitat: Herb; terrestrial, forested slope between Baixio and higher terrace.

Material examined: Manoel Urbano, D.C. Daly et al. 11421 (NY). 
World Distribution: S Mexico, Antilles, Mesoamerica, and tropical South America.

Characterized by 3-4-pinnate-pinnatifid laminae, proximal pinna enlarged basiscopically, rachises and pinna rachises pubescent, buds present on the rachises distally, veins free, sori round, exindusiate. A large species. In herbaria, a single leaf is often mounted on two or three sheets.

Polybotrya Humb. \& Bonpl. ex Willd., Sp. Pl. 5(1): 99. 1810.

Distinctive in Acre by terrestrial root-climbing habit, free veins, sterile-fertile leaf dimorphy, and caudate fertile pinnules. The rhizome in cross section is distinctive for the genus. It contains up to 12 meristeles arranged circularly, each meristele surrounded by a dark sclerenchymatous sheath. The sheaths contrast strongly with the white ground tissue. The laminae 1-pinnate to 4-pinnate, the apex pinnatifid; veins free or anastomosing; indusia absent. Might be confused with Lomariopsis, but that genus has 1-pinnate laminae with a conform apical segment resembling the lateral pinnae.

Polybotrya was revised by Moran (1987). It is a terrestrial rootclimber, starting on the soil, with the long-creeping rhizomes climbing when they find a trunk. Fertile leaves are produced on the climbing portion of the rhizome. The connection between the terrestrial and climbing portions of the rhizomes are maintained throughout the life of the plant.

Neotropical; ca. 35 species, 2 in Acre.

1. Sterile leaves 1-pinnate-pinnatisect; rhizome scales pale brown or whitish, thin, ovate P. pubens

1. Sterile leaves 2-pinnate-pinnatifid; rhizome scales dark brown, thick, linear P. caudata

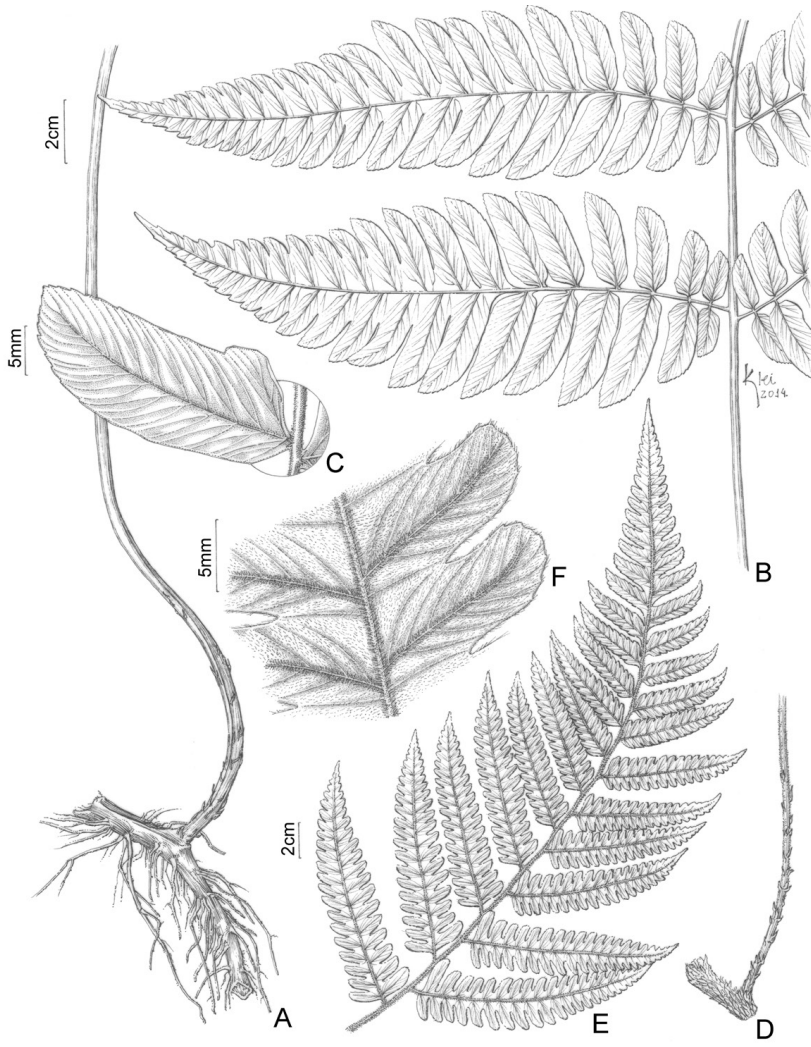

Figure 21. A-C. Polybotrya caudata (Prado et al. 1143, SP). A. Rhizome and petiole. B. Part of a sterile frond. C. Venation of the sterile frond. D-F. Polybotrya pubens (Prado et al. 1207, SP). D. Rhizome and petiole. E. Part of a sterile frond. F. Venation of the sterile frond with hairs.
Polybotrya caudata Kunze, Linnaea 9: 23. 1834

Figures: 21A-C

Habit/Habitat: Herb; terrestrial root-climber, in terra firme forest.

Material examined: Cruzeiro do Sul, J. Prado et al. 1295 (SP, UFACPZ); Mâncio Lima, J. Prado et al. 1143 (SP, UFACPZ), J. Prado et al. 1145 (SP, UFACPZ), G.T. Prance et al. 12069 (NY), M. Silveira et al. 1662 (NY).

World Distribution: S Mexico, Mesoamerica, and N South America to Bolivia.

Besides the characters in the key, this species differs from Polybotrya pubens by the rachises and costae almost glabrous, the hairs shorter than $1 \mathrm{~mm}$ long.

Polybotrya pubens Mart., Icon. P1. Crypt. 87, tab. 25. 1834.

Figures: 21D-F

Habit/Habitat: Herb; terrestrial root-climber, in terra firme forest.

Material examined: Cruzeiro do Sul, J. Prado et al. 1205 (SP, UFACPZ), J. Prado et al. 1207 (SP, UFACPZ), J. Prado et al. 1394 (SP, UFACPZ).

World Distribution: N South America to Bolivia.

Besides the characters in the key, Polybotrya pubens differs from $P$. caudata by the rachises and costae long-pubescent, the hairs $1-2.5 \mathrm{~mm}$ long.

\section{GLEICHENIACEAE}

Characterized by long-creeping rhizomes with leaves arranged dorsally in a single row (orthostichous), and laminae with pseudodichotomous branches. A resting bud usually occurs in the forks of the laminae. Petioles

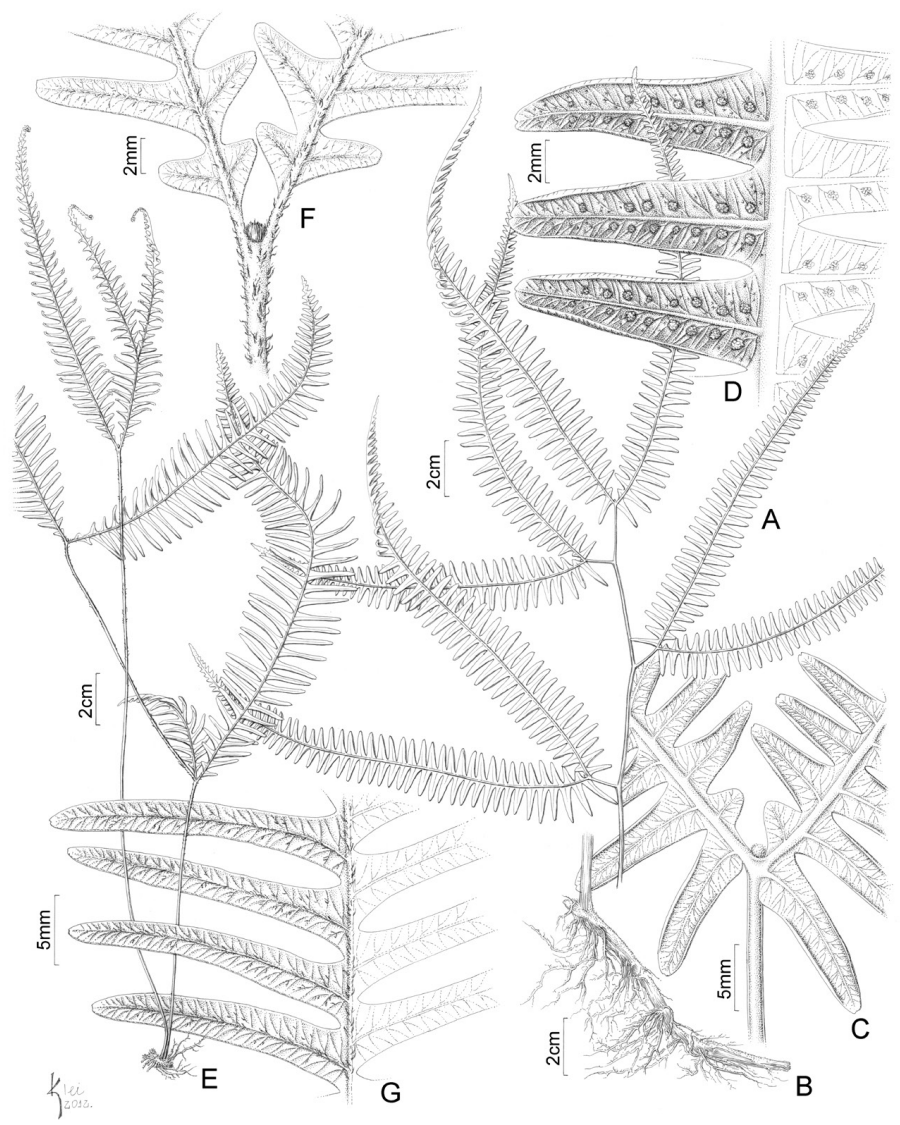

Figure 22. A-D. Gleichenella pectinata (Prado et al. 1189, SP). A. Part of a sterile frond. B. Rhizome. C. Ultimate fork. D. Fertile segments. E-G. Sticherus remotus (Prado et al. 1300, SP). E. Habit (juvenile). F. Ultimate fork. G. Sterile segments and venation. 
in cross-section with a C-shaped vascular bundle with inrolled arms. Plants often forming large colonies in disturbed environments, such as steep banks, roadsides, and landslides.

Pantropical; 6 genera, ca. 157 species; 2 genera and 3 species in Acre.

1. Rhizomes and the buds in forks of the pinnae pubescent; sporangia 8-25 per sorus; veins 2- to 4-forked

Gleichenella

1. Rhizomes and the buds in forks of the pinnae scaly; sporangia $2-5(-6)$ per sorus; veins simple or 1 -forked Sticherus

Gleichenella Ching, Sunyatsenia 5(4): 276. 1940.

A monotypic genus. Beside the characters in the key, characterized by branches of unequal length in each pseudodichotomy. The fresh leaves are a light lime or yellowish green and for that reason often stand out against the darker foliage of the surrounding vegetation.

Gleichenella pectinata (Willd.) Ching, Sunyatsenia 5(4): 276. 1940 Mertensia pectinata Willd., Kongl. Vetensk. Acad. Nya Handl. 25: 168, tab. 4. 1804.

Figures: $22 \mathrm{~A}-\mathrm{D}$

Habit/Habitat: Herb; terrestrial along forest margins.

Material examined: Cruzeiro do Sul, J. Prado et al. 1189 (SP, UFACPZ); Mâncio Lima, G.T. Prance et al. 12119 (MG, NY), M. Silveira et al. 1348 (NY, UFACPZ).

World Distribution: S Mexico, Antilles, Mesoamerica, and tropical South America.

\section{Sticherus C. Presl, Tent. Pterid. 51-52. 1836.}

Besides the characters in the key, characterized by branches with equal length in each pseudodichotomy and ultimate segments pectinate.

Pantropical; ca. 90 species (ca. half are Neotropical; Gonzales \& Kessler 2011); 2 species in Acre.

1. Scales on the buds in the forks of the pinnae $1-1.5 \mathrm{~mm}$ long

S. remotus

1. Scales on the buds in the forks of the pinnae $2-3 \mathrm{~mm}$ long

S. longipinnatus

Sticherus longipinnatus (Hook.) Ching, Sunyatsenia 5: 283. 1940 Gleichenia longipinnata Hook., Sp. Fil. 1: 9. 1844.

Habit/Habitat: Herb; terrestrial, steep rocky river margins.

Material examined: Cruzeiro do Sul, Prance et al. 12681 (NY).

World Distribution: Suriname, Ecuador, Peru, Brazil.

Characterized by many narrow long-setose scales on the pinna-rachises and costules abaxially.

Sticherus remotus (Kaulf.) Chrysler, Amer. J. Bot. 31(8): 483.1944 Mertensia remota Kaulf., Enum. Filic. 39. 1824.

Figures: $22 \mathrm{E}-\mathrm{G}$

Habit/Habitat: Herb; terrestrial along forest margins.

Material examined: Cruzeiro do Sul, J. Prado et al. 1300 (SP, UFACPZ). World Distribution: Mesoamerica and N South America.

Easily identified by the narrow ultimate segments only ca. $2 \mathrm{~mm}$ wide.

\section{HEMIDICTYACEAE}

Characterized by leaves $0.5-1.5 \mathrm{~m}$ long; petioles with 2 vascular bundles that unite distally in a U-shape, laminae 1-pinnate with a conform terminal segment; and veins near the costae free but anastomosing toward the pinna margins. The vein tips are connected by a continuous submarginal connecting strand. Resembling Desmophlebium but distinguished by thin laminae, opposite pinnae, netted veins, and non-decurrent distal pinnae. Segregated from Woodsiaceae by Christenhusz et al. (2011).

Neotropical; 1 genus, 1 species.

Hemidictyum C. Presl, Tent. Pterid. 110-111, tab. 3, fig. 24-26. 1836.

Same characters as the family.

Hemidictyum marginatum (L.) C. Presl, Tent. Pterid. 111, tab. 3, fig. 24. 1836. Asplenium marginatum L., Sp. Pl. 2: 1082. 1753.

Figures: 23A, B

Habit/Habitat: Herb; terrestrial in várzea forest.

Material examined: Cruzeiro do Sul, G.T. Prance et al. 12479 (NY).

World Distribution: S Mexico, Antilles, Mesoamerica, and tropical South America.

\section{HYMENOPHYLLACEAE}

Characterized by pubescent rhizomes, laminae only 1 cell thick between the veins, petioles with a single vascular bundle; marginal sori, and green spores. Referred to as "filmy ferns" because of their membranous leaves. The laminae are so thin and transclucent that, with magnification $(10 \times)$ individual cells can be easily seen.

Pantropical, with extensions into the temperate zones; 9 genera, ca 434 species. In Acre, 4 genera, 17 species.

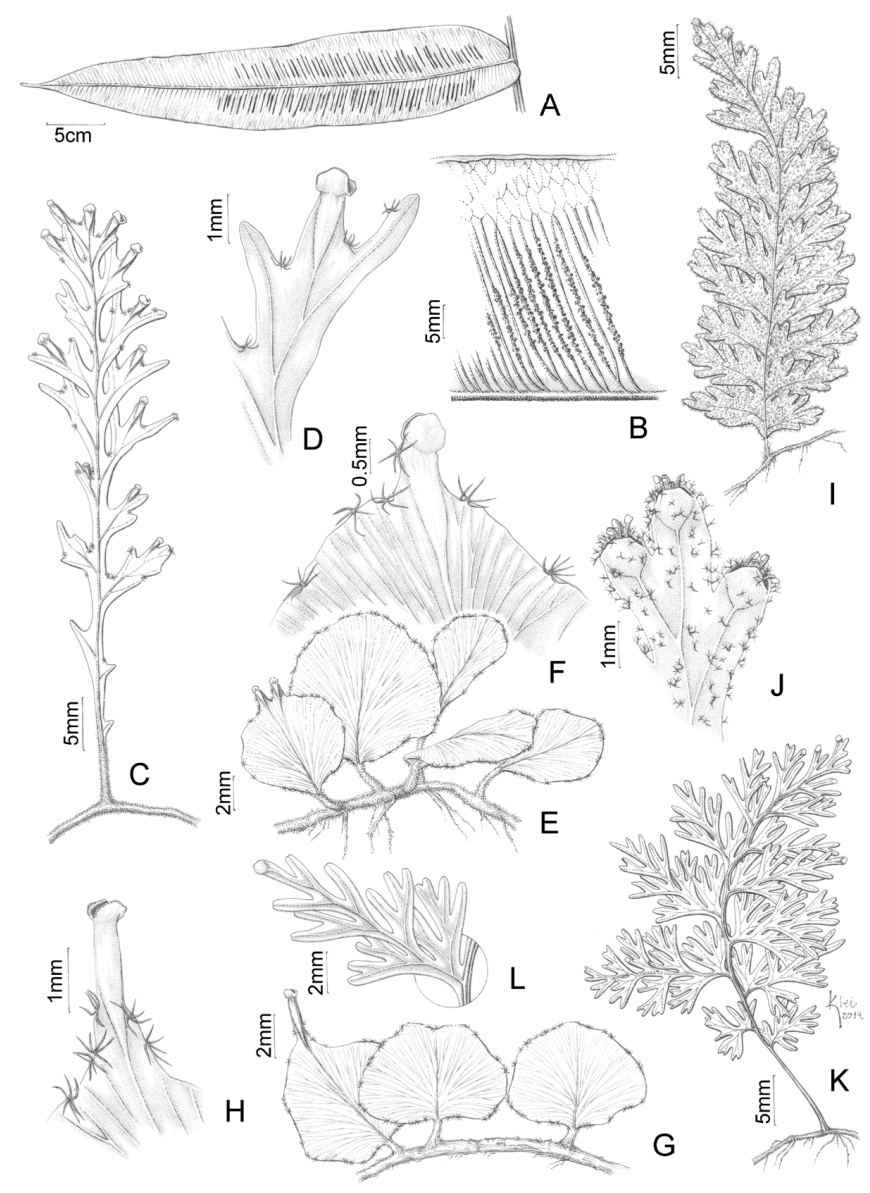

Figure 23. A, B. Hemidictyum marginatum (Prance et al. 12479, NY). A. Fertile pinna. B. Venation and sori. C, D. Didymoglossum krausii (Daly et al. 9115, NY) C. Habit. D. Sorus. E, F. Didymoglossum ovale (Prado et al. 1230, SP). E. Habit. F. Sorus. G, H. Didymoglossum punctatum subsp. labiatum (Daly et al. 10330, NY) G. Habit. H. Sorus. I, J. Hymenophyllum angustum (Prado et al. 1153, SP). I. Habit. J. Sorus. K, L. Hymenophyllum polyanthus (Prado et al. 1149, SP). K. Habit. L. Sorus. 
1. Indusia bivalvate; receptacles included in the indusia, not visible ..... Hymenophyllum

1. Indusia tubular or conic; receptacles exserted from the indusia, hairlike

2. Leaves up to $6 \mathrm{~cm}$ long Didymoglossum

2. Leaves more than $6 \mathrm{~cm}$ long

3. Plants hemiepiphytic Vandenboschia

3. Plants terrestrial, less commonly epiphytic Trichomanes

Didymoglossum Desv., Mém. Soc. Linn. Paris 6: 330. 1827.

Characterized by slender, long-creeping, densely black-pubescent rhizomes; leaves less than $6 \mathrm{~cm}$ long, false veins present between the main lateral ones; and dark, usually forked or stellate hairs on the margins of the laminae. It is entirely epiphytic; rhizomes lack roots; instead, the plants are fastened to the substrate by dense blackish adhesive hairs on the rhizomes and (in some species) the petioles and rachises. The leaves are small and vary from entire to bipinnatifid. The distinctive false veins may be seen as short, faint streaks between the true veins (magnification needed). Continuous submarginal false veins are absent.

Pantropical; ca. 30 species, 3 in Acre.

1. Leaves pinnatifid or bipinnatifid D. krausii

1. Leaves entire

2. Sori 1 per leaf; involucres partially immersed in the laminar tissue, laminar margins with 1 or 2 rows of darkened cells ..... D. ovale

2. Sori 2 or more per leaf; involucres projecting beyond the laminar tissue, laminar margins with 3 or more rows of darkened cells.......

D. punctatum subsp. labiatum

Didymoglossum krausii (Hook. \& Grev.) C. Presl, Hymenophyllaceae 115. 1843. Trichomanes krausii Hook. \& Grev., Icon. Filic. 2: tab. 149. 1830

Figures: 23C, D

Habit/Habitat: Herb; epiphyte in forest.

Material examined: Manoel Urbano, D.C. Daly et al. 9115 (NY, UFACPZ).

World Distribution: Florida, Mexico, Antilles, Mesoamerica, and tropical South America.

Characterized by the combination of leaves pinnatifid to bipinnatifid, 1-4 cm long, rachises abaxially densely pubescent, the hairs dark brown to blackish, and laminae adaxially glabrous. The hairs on the laminar margins may be simple, forked, or stellate. The stellate hairs are typically present in each sinus.

Didymoglossum ovale E. Fourn., Bull. Soc. Bot. France 19: 249.1872[1873].

Figures: 23E, F

Habit/Habitat: Herb; epiphyte along river margins.

Material examined: Cruzeiro do Sul, J. Prado et al. 1288 (UFACPZ); Mâncio Lima, J. Prado et al. 1230 (SP, UFACPZ).

World Distribution: S Mexico, Antilles, Mesoamerica, and N South America to Bolivia.

Characterized by entire leaves only $3-8 \mathrm{~mm}$ long, orbicular in the young plants and elliptical or spathulate in adult plants, sori in general only one per leaf, partially immersed in the laminar tissue, and labia with 1 or 2 rows of darkened marginal cells.

Didymoglossum punctatum (Poir.) Desv. subsp. labiatum (Jenman) Boudrie \& Cremers, Amer Fern J. 106(3): 172. 2016. Trichomanes labiatum Jenman, Gard. Chron., n.s. 24: 7. 1885.
Habit/Habitat: Herb; epiphyte.

Material examined: Marechal Thaumaturgo, D.C. Daly et al. 10330 (NY). World Distribution: Mesoamerica, Antilles, and N South America.

Characterized by small (5-15 $\mathrm{mm}$ long) leaves that vary from entire, orbicular to ovate, sori more than one per leaf; involucre of the sori projecting beyond the laminar tissue, labia with 3 or more rows of darkened marginal cells.

Hymenophyllum Sm., Mém. Acad. Roy. Sci. (Turin) 5: 418, tab. 9, fig. 8. 1793 .

Characterized by epiphytic habit, bilabiate indusia, and receptacles shorter than the mouth of the indusia, therefore not visible. The plants tend to dry reddish, in contrast to the trichomanioid genera, which usually dry green or gray-green. Rhizomes usually filiform, long-creeping, pubescent; sterile and fertile leaves typically $1-30 \mathrm{~cm}$ long, monomorphic; laminae membranaceous, usually translucent, 1-cell thick except around the veins, simple to 3-pinnate, glabrous or pubescent (the hairs simple, forked, or stellate); veins free, anadromous, false veins absent; sori marginal, round to ovate.

Pantropical; ca. 250 species, 2 in Acre.

1. Leaves pubescent H. angustum

1. Leaves glabrous H. polyanthos

Hymenophyllum angustum Bosch, Ned. Kruidk. Arch. 5(2): 183. 1861.

Figures: 23I, J

Habit/Habitat: Herb; epiphyte in waterlogged low-lying areas; typically on the root mantles of tree ferns.

Material examined: Cruzeiro do Sul, J. Prado et al. 1153 (SP, UFACPZ).

World Distribution: Amazonian Brazil and Bolivia.

Characterized by filiform (ca. $1 \mathrm{~mm}$ diam), long-creeping rhizomes, laminae pinnatifid to bipinnatifid, with stellate hairs evenly distributed on both laminar surfaces of the laminar tissue, on veins, and margins.

Hymenophyllum polyanthos (Sw.) Sw., J. Bot. (Schrader) 1800(2): 102. 1801. Trichomanes polyanthos Sw., Prodr. 137. 1788.

Figures: $23 \mathrm{~K}, \mathrm{~L}$

Habit/Habitat: Herb; epiphyte in forest.

Material examined: Cruzeiro do Sul, P.J.M. Maas et al. 12722 (NY), J. Prado et al. 1149 (SP, UFACPZ), J. Prado et al. 1389 (SP, UFACPZ); Mâncio Lima, J. Prado et al. 1222 (SP, UFACPZ).

World Distribution: Mexico, Mesoamerica, and tropical South America.

Characterized by long-creeping filiform (ca. $1 \mathrm{~mm}$ diam.) stems and bipinnatifid, glabrous laminae.

Trichomanes L., Sp. Pl. 2: 1097-1099. 1753.

Characterized by cylindrical or funnelform marginal indusia. Unlike Hymenophyllum, it may also be terrestrial. It consists of four main clades, which are recognized as subgenera by Ebihara et al. (2007).

Pantropical; ca. 60 species, 11 in Acre.

1. Hemiepiphytic; leaves appressed against the substrate

2. Laminae 1-pinnate-pinnatifid, segments pinnatifid ...... T. ankersii

2. Laminae simple, linear.

T. tanaicum

1. Terrestrial; leaves not appressed to the substrate

3. Sterile and fertile leaves dimorphic

4. Sterile laminae with apices often flagellate and proliferous T. trollii

4. Sterile laminae with apices not proliferous 
5. Rhizomes long-creeping; fertile laminae pinnatisect, linear

T. humboldtii

5. Rhizomes erect; fertile laminae 1-pinnate, deltate

T. pinnatum

3. Sterile and fertile leaves monomorphic

6. Laminae 3- to 4-pinnate, iridescent (when living); sori oriented downward out of the plane of the lamina

T. elegans

6. Laminae pinnatisect to 1-pinnate to tripinnatifid, not iridescent; sori oriented marginally in the same plane as the lamina

7. Laminae deeply pinnatisect or tripinnatifid; petioles conspicuously alate

8. Laminae tripinnatifid; ultimate segments $1-2 \mathrm{~mm}$ wide ... T. bicorne

8. Laminae deeply pinnatisect; ultimate segments $2-4 \mathrm{~mm}$ wide ....

T. macilentum

7. Laminae 1-pinnate; petioles not alate

9. Lamina apices with a conform terminal pinnae or flagellate and proliferous at the tip

T. hostmannianum

9. Lamina apices tapered, pinnatifid, non-proliferous

10. Veins adaxially with perpendicular wings; basal pinnae deflexed

T. martiusii

10. Vein adaxially without perpendicular wings; basal pinnae not deflexed

T. crispum

Trichomanes ankersii C. Parker ex Hook. \& Grev., Icon. Filic. 2(11): tab. 201. 1831.

Figures: 24A, B

Habit/Habitat: Herb; hemiepiphyte, in terra firme forest.

Material examined: Cruzeiro do Sul, J. Prado et al. 1150 (SP, UFACPZ), J. Prado et al. 1158 (SP, UFACPZ), J. Prado et al. 1168 (SP, UFACPZ), J. Prado et al. 1214 (SP, UFACPZ), J. Prado et al. 1312 (SP, UFACPZ), J. Prado et al. 1387 (SP, UFACPZ), G.T. Prance et al. 11854 (MG, NY); Rodrigues Alves, J. Prado et al. 1236 (SP, UFACPZ), J. Prado et al. 1257 (SP, UFACPZ).

World Distribution: Mesoamerica and N South America to Bolivia.

Characterized by hemiepiphytic habit, long-creeping rhizomes, leaves pressed flat against the substrate, laminae 1-pinnate-pinnatifid, segments pinnatifid, indusia tubular and projected out of the laminar tissue, and receptacles exserted.

Trichomanes bicorne Hook., Icon. Plan. 9: tab. 892. 1854.

Figures: 24C, D

Habit/Habitat: Herb; terrestrial, in terra firme forest.

Material examined: Cruzeiro do Sul, D.C. Daly et al. 10613 (NY), J. Prado et al. 1147 (SP, UFACPZ), J. Prado et al. 1176 (SP, UFACPZ), J. Prado et al. 1268 (SP, UFACPZ), J. Prado et al. 1323 (SP, UFACPZ), J. Prado et al. 1271 (SP, UFACPZ).

World Distribution: N South America.

Characterized by erect rhizomes, leaves finely divided, laminae tripinnatifid, rhombic, petioles winged, the wings formed by the decurrent lamina, ultimate segments only $1-2 \mathrm{~mm}$ wide, sori marginal, indusia conic, and receptacles exserted.

Trichomanes crispum L., Sp. Pl. 2: 1097. 1753.
Figures: 24E, F

Habit/Habitat: Herb; terrestrial, in terra firme forest.

Material examined: Cruzeiro do Sul, J. Prado et al. 1313 (SP, UFACPZ), J. Prado et al. 1380 (SP, UFACPZ).

World Distribution: S Mexico, Antilles, Mesoamerica, and N South America to Bolivia.

Distinguished by monomorphic sterile and fertile leaves, laminae 1-pinnate, rachises conspicuously alate throughout, the wing undulate to crispate, veins and laminar margins sparsely pubescent, the hairs simple or forked, sori borne on apices of the pinnae, indusia immersed on the laminar tissue, and receptacles exserted.

Trichomanes elegans Rich., Actes Soc. Hist. Nat. Paris 1: 114. 1792.

Figures: $24 \mathrm{G}, \mathrm{H}$

Habit/Habitat: Herb; terrestrial, in forest near stream margins.

Material examined: Cruzeiro do Sul, J. Prado et al. 1212 (SP, UFACPZ), G.T. Prance et al. 12225 (MG, NY); Mâncio Lima, M. Silveira et al. 1247 (NY), M. Silveira et al. 1250 (NY); Rodrigues Alves, J. Prado et al. 1364 (SP, UFACPZ).

World Distribution: Antilles, Mesoamerica, and tropical and subtropical South America.

Distinctive by iridescent laminae 3- to 4-pinnate and marginal sori oriented downward, out of the plane of the lamina. Unlike other Hymenophyllaceae, its laminae are three cell layers thick between the veins. The lamina dry blackish. Other features that characterize this species are terrestrial habit, erect or suberect rhizomes, leaves up to

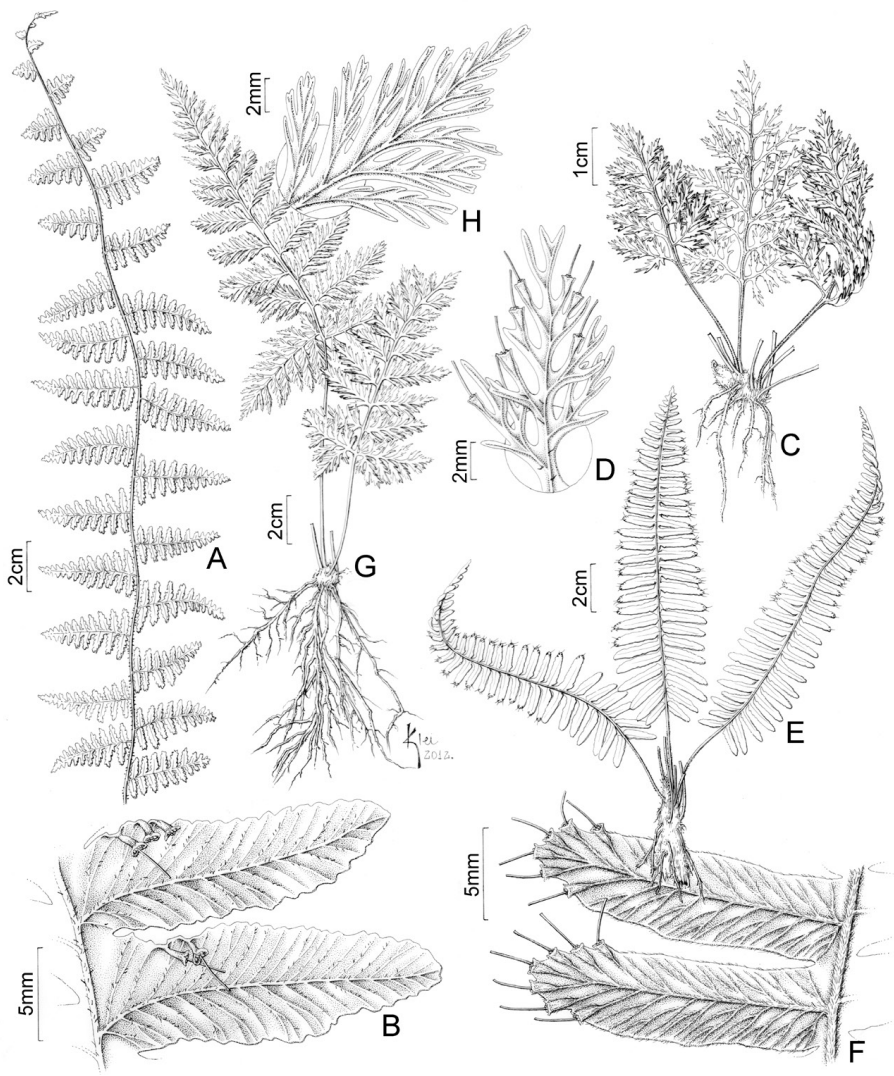

Figure 24. A, B. Trichomanes ankersii (Prado et al. 1387, SP). A. Habit. B. Sori C, D. Trichomanes bicorne (Prado et al. 1147, SP). C. Habit. D. Fertile segments. E, F. Trichomanes crispum (Prado et al. 1380, SP). E. Habit. F. Fertile segments. G, H. Trichomanes elegans (Prado et al. 1212, SP). G. Habit. H. Sterile segments. 
$60 \mathrm{~cm}$ long, veins free, anadromous, false veins absent, indusia tubular, and receptacles exserted.

Trichomanes hostmannianum (Klotzsch) Kunze, Bot. Zeitung (Berlin) 5: 352. 1847. Neurophyllum hostmannianum Klotzsch, Linnaea 18: 532. $1844[1845]$.

Figures: $25 \mathrm{~A}-\mathrm{C}$

Habit/Habitat: Herb; terrestrial, in forest near stream margins on wet soils. Material examined: Cruzeiro do Sul, L.R. Marinho 217 (NY), J. Prado et al. 1194 (SP, UFACPZ); Rodrigues Alves, J. Prado et al. 1272 (SP, UFACPZ).

World Distribution: N South America to Bolivia.

Characterized by terrestrial habit, monomorphic sterile and fertile leaves, 1-pinnate and deltate laminae, and rachises narrowly alate, the wings ca. $1 \mathrm{~mm}$ wide. The apices may be either conform (similar shape as the lateral pinnae) or flagellate and proliferous at the tip.

Trichomanes humboldtii (Bosch) Lellinger, Mem. New York Bot. Gard. 38: 35. 1984. Feea humboldtii Bosch, Syn. Hymenophyll. 7 (postpr. 347). 1858.

Figures: 25J, K

Habit/Habitat: Herb; terrestrial in forest on terra firme.

Material examined: Cruzeiro do Sul, J. Prado et al. 1182 (SP, UFACPZ). World Distribution: N South America.

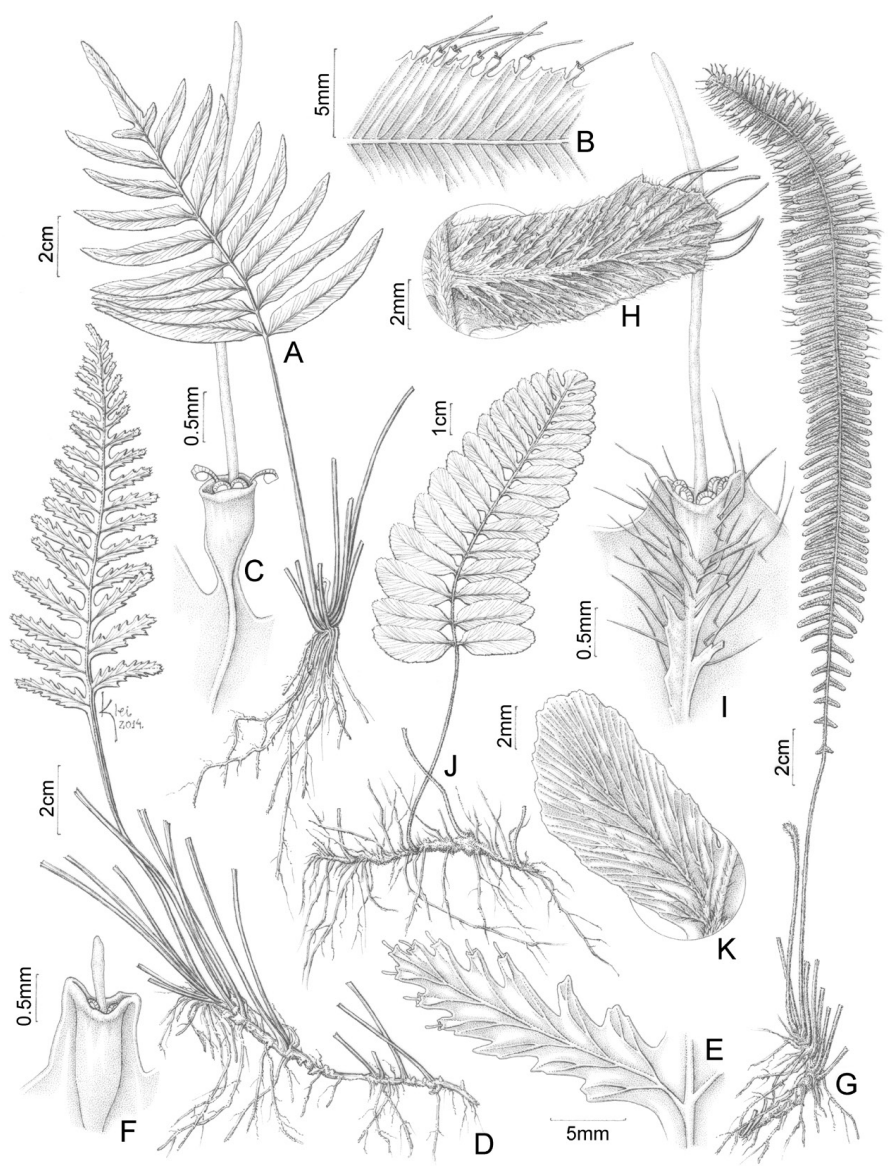

Figure 25. A-C. Trichomanes hostmannianum. A. Habit (Prado et al. 1194, SP). B. Part of a fertile segment. C. Sorus (B, C. Prado et al. 1272, SP). D-F. Trichomanes macilentum (Prado et al. 1385, SP). D. Habit. E. Fertile segment. F. Sorus. G-I. Trichomanes martiusii (Prado et al. 1217, SP). G. Habit. H. Fertile segment. I. Sorus. J, K. Trichomanes humboldtii (Prado et al. 1182, SP). J. Habit. K. Sterile segment.
Characterized by creeping rhizomes, leaves ovate-lanceolate, 1-pinnate, pinnae overlapping each other, rachises winged, petioles non-alate at base and alate distally, axes and veins pubescent on both surfaces. The laminae of fertile leaves are plicate.

Windisch (1979) used the name Trichomanes heterophyllum Humb. \& Bonpl. ex Kunth for this species, but that name is illegitimate. Prado \& Moran (2009) mistakenly identified this specimen as Trichomanes pilosum Raddi.

Trichomanes macilentum Bosch, Ned. Kruidk. Arch. 5(2): 146. 1861.

Figures: 25D-F

Habit/Habitat: Herb; terrestrial in waterlogged low-lying areas.

Material examined: Cruzeiro do Sul, J. Prado et al. 1385 (SP, UFACPZ).

World Distribution: N South America.

Characterized by monomorphic sterile and fertile leaves, deeply pinnatisect-pinnatifid laminae, ultimate segments 2-4 mm wide, and sori borne on the margins and apices of the segments. Collected only once in Acre, where it was found growing on fallen logs. Elsewhere it also occurs on mossy rocks.

Trichomanes martiusii C. Pres1, Hymenophyllaceae 15, 36. 1843.

Figures: 25G-I

Habit/Habitat: Herb; terrestrial in forest on terra firme, on sandy soils.

Material examined: Cruzeiro do Sul, J. Prado et al. 1146 (SP, UFACPZ), J. Prado et al. 1171 (SP, UFACPZ), J. Prado et al. 1269 (SP, UFACPZ), J. Prado et al. 1326 (SP, UFACPZ), N.A. Rosa 657 (NY); Mâncio Lima, J. Prado et al. 1217 (SP, UFACPZ).

World Distribution: N South America.

Characterized by leaves 1-pinnate, narrowly elliptic or lanceolate laminae that are gradually reduced to the base and pinnatifid apex, proximal pinnae deflexed, axes and veins pubescent, the hairs uni- or pluricellular, veins abaxially with perpendicular laminar wings. A common species in Acre.

Trichomanes pinnatum Hedw., s.l., Fil. Gen. Sp. tab. 4, fig. 1. 1799.

Figures: $26 \mathrm{~A}-\mathrm{C}$

Habit/Habitat: Herb; terrestrial in forest on terra firme, on clay and sand soils.

Material examined: Assis Brasil, D.C. Daly et al. 9608 (NY, UFACPZ); Cruzeiro do Sul, J. Prado et al. 1183 (UFACPZ), J. Prado et al. 1311 (SP, UFACPZ), D.C. Daly et al. 11640 (NY); Mâncio Lima, D.C. Daly et al.11589 (NY, UFACPZ), G.T. Prance et al. 12178 (MG, NY); Porto Valter, D.C. Daly et al. 7576 (NY, UFACPZ), D. C. Daly et al. 11739 (NY), P.J.M. Maas et al. 13010 (MG, NY); Rodrigues Alves, J. Prado et al. 1244 (UFACPZ); Sena Madureira, G.T. Prance et al. 7730 (NY), G.T. Prance et al. 7948 (NY).

World Distribution: S Mexico, Antilles, Mesoamerica, and N South America to Bolivia.

Characterized by faint cross-veins (false veins) between the main lateral veins (magnification needed). Also distinctive by its pinnate laminae with apices often flagellate and proliferous at the tip. The rhizomes are erect and supported by stilt roots. Leaves radially arranged. The material studied for this taxon and cited above probably belongs to two or three species, but more studies are necessary to clarify the taxonomy.

Trichomanes tanaicum Hook. ex J.W. Sturm., Fl. Bras. 1(2): 260. 1859.

Figures: 26D-F

Habit/Habitat: Herb; hemiepiphyte, in terra firme forest.

Material examined: Cruzeiro do Sul, J. Prado et al. 1209 (UFACPZ); Rodrigues Alves, J. Prado et al. 1254 (SP, UFACPZ), J. Prado et al. 1258 (UFACPZ). 
World Distribution: N South America to Bolivia.

Characterized by hemiepiphyte growth habit with the leaves appressed to trunks and sori turned outward, perpendicular to the substrate. Further distinctive by simple, linear laminae and tubular indusia.

Trichomanes trollii Bergdolt, Flora 127: 256, 264, fig. 3. 1933.

Figures: 26G-I

Habit/Habitat: Herb; terrestrial, in forest on terra firme.

Material examined: Rodrigues Alves, J. Prado et al. 1366 (SP, UFACPZ).

World Distribution: N South America to Bolivia.

Characterized by the leaves to $30 \mathrm{~cm}$ long, the sterile and fertile ones dimorphic, sterile laminae 1-pinnate, the apices often flagellate and proliferous, veins free, catadromous, false veins absent, fertile laminae entire, linear, margins crenate, sori marginal, and indusia tubular.

Vandenboschia Copel., Philipp. J. Sci. 67(1): 51. 1938.

Hemiepiphytic or hemiepilithic, with roots many and robust; rhizomes 1-2 mm diam, long-creeping, irregularly branching, densely pubescent, the hairs dark, multicellular; sterile and fertile leaves to $40 \times 20 \mathrm{~cm}$, monomorphic; laminae membranaceous, translucent, 1-cell thick between the veins, 1-pinnate to 5-pinnate; veins free, anadromous, false veins absent; sori marginal; indusia tubular to campanulate, the mouth entire, flaring; receptacles exserted, extending beyond the mouth of the indusium.

Pantropical; 15 species, 1 in Acre.

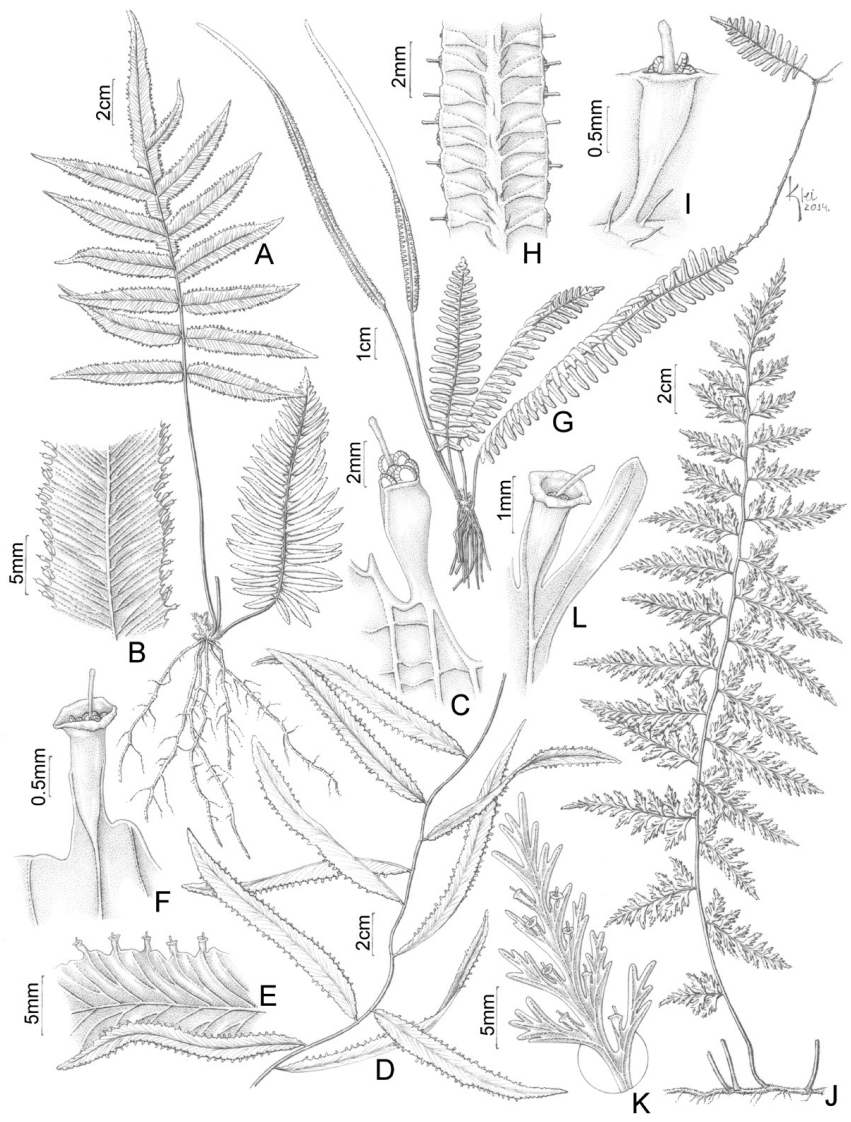

Figure 26. A-C. Trichomanes pinnatum (Daly et al. 7576, NY). A. Habit. B. Part of a fertile segment. C. Sorus. D-F. Trichomanes tanaicum. D. Part of habit (Prado et al. 1254, SP). E. Part of a fertile segment (from Brazil, Amazonas, Maraã, Plowman et al. 12169a, NY). F. Sorus (Plowman et al. $12169 a$, NY). G-I. Trichomanes trollii (Prado et al. 1366, SP). G. Habit. H. Part of a fertile segment. I. Sorus. J-L. Vandenboschia collariata (Jangoux et al. 85-073, NY). J. Habit. K. Fertile segments. L. Sorus.
Vandenboschia collariata (Bosch) Ebihara \& K. Iwats., Blumea 51(2): 242. 2006. Trichomanes collariatum Bosch, Ned. Kruidk. Arch. 4: 368. 1859[1858].

Figures: 26J-L

Habit/Habitat: Herb; epiphyte in forest on terra firme.

Material examined: Without locality, J. Jangoux et al. 85-053 (MG, NY), J. Jangoux et al. 850-073 (MG, NY).

World Distribution: Mexico, Mesoamerica, and N South America to Bolivia.

Characterized by hemiepiphytic or hemiepilithic habit, and 2- or 3-pinnatifid leaves borne along slender, long-creeping rhizomes. The growth habit is distinctive (Nitta \& Epps, 2009). Short horizontal or oblique rhizomes occur on the base of trunks, generally $10-30 \mathrm{~cm}$ above the soil. These short rhizomes do not produce leaves. Instead, they give rise to the roots that branch profusing when they reach the soil. They also give rise to long-creeping, climbing rhizomes that bear the leaves. These climbing rhizomes are attached to the substrate by dark adhesive hairs.

\section{LINDSAEACEAE}

Characterized by rhizomes short- to long-creeping, hairy or scaly; petioles with a single vascular bundle, adaxially grooved; lamina architecture extremely variable; veins free or anastomosing; sori supramedial, close to the margin, with paraphyses; spores trilete or (rarely) monolete.

Lindsaea may be either terrestrial, rarely rupestral or epiphytic. The laminae often have dimidiate pinnae or pinnules, adaxially grooved rachises and costae, sori borne near the laminar margins, and indusia that open toward the margin (not toward the midrib). The genus resembles Adiantum but differs by stramineous to green petioles, rachises, and costae (these atropurpureous or castaneous in Adiantum), and sori protected by true indusia borne submarginally on the laminar surface and opening toward the margin (vs. in Adiantum formed by the reflexed margins of the lamina and opening toward the midrib).

Pantropical; 9 genera, ca. 234 species. In Acre, 1 genus, 9 species.

Lindsaea Dryand. ex Sm., Mém. Acad. Roy. Sci. (Turin) 5: 413, tab. 9, fig. 4. 1793 .

Characters of the family.

1. Leaves 1-pinnate

2. Laminae strongly reduced toward the apex

L. stricta

2. Laminae not reduced or only slightly so toward the apex

3. Terminal pinna asymmetrical, approximately triangular, trilobed, apex obtuse

L. falcata

3. Terminal pinna flabellate or hastate, apex acute

4. Medial pinnae overlapping each other; terminal pinna flabellate, $2-3.5 \times 1.5-4 \mathrm{~cm}$, laterally subacute to round

L. schomburgkii

4. Medial pinnae spaced; terminal pinna hastate, $2-4 \times 4-10$ $\mathrm{cm}$, laterally acute, long-attenuate to caudate L. ulei

1. Leaves 2-pinnate

5. Pinnae strongly reduced apically...... L. stricta

5. Pinnae slightly or not reduced apically

6. Pinna apices not reduced apically. L. hemiglossa

6. Pinna apices slightly reduced apically 
7. Medial pinnules $5-8 \times$ longer than wide; terminal pinnule narrowly lanceolate, subhastate-lobed at base

L. taeniata

7. Medial pinnules $2-4 \times$ longer than wide; terminal pinnule asymmetrical, approximately triangular, trilobed

8. Petioles and rachises dark brown to tan

L. divaricata

8. Petioles and rachises greenish or pale

9. Medial pinnules trapeziform, $2-4 \times$ longer than wide

Lindsaea sp.

9. Medial pinnules semilunate, $3 \times$ longer than wide

L. lancea

Lindsaea divaricata Klotzsch, Linnaea 18: 547. 1844[1845].

Figures: $27 \mathrm{~A}-\mathrm{C}$

Habit/Habitat: Herb; terrestrial in forest on terra firme, on sandy soils.

Material examined: Cruzeiro do Sul, T.B. Croat \& A. Rosas Jr. 62671 (NY), J. Prado et al. 1151 (SP, UFACPZ), J. Prado et al. 1177 (SP, UFACPZ), J. Prado et al. 1270 (SP, UFACPZ); Mâncio Lima, Silveira et al. 1246 (NY); Rodrigues Alves, J. Prado et al. 1359 (SP, UFACPZ).

World Distribution: Mesoamerica and tropical South America.

Characterized by leaves 2-pinnate, terminal pinna similar than the lateral ones, and wing-like ridges present on the adaxial side of the secondary

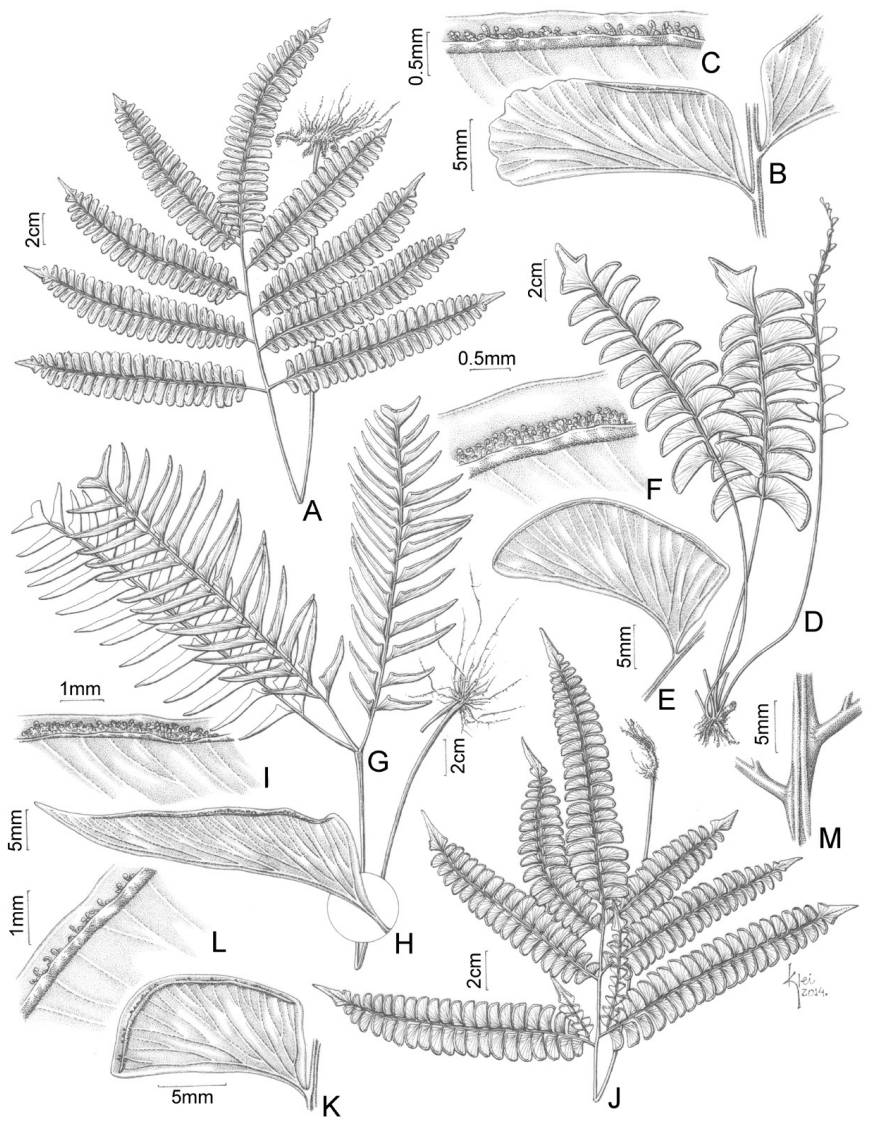

Figure 27. A-C. Lindsaea divaricata. A. Habit (Prado et al. 1270, SP). B. Venation of the fertile segment. C. Sorus (B, C. Prado et al. 1359, SP). D-F. Lindsaea falcata (Prado et al. 1308, SP). D. Habit. E. Venation of the fertile segment. F. Sorus. G-I. Lindsaea hemiglossa (Prance et al. 11931, NY). G. Habit. H. Venation of the fertile segment. I. Sorus. J-M. Lindsaea lancea (Prado et al. 1309, SP). J. Habit. K. Venation of the fertile segment. L. Sorus. M. Rachis adaxially. rachises. The wing-like ridges are light brown; in contrast, the petioles and rachises are dark brown to tan.

Lindsaea falcata Dryand., Trans. Linn. Soc. London 3: 41, tab. 7, fig. 2. 1797.

Figures: 27D-F

Material examined: Cruzeiro do Sul, J. Prado et al. 1148 (SP, UFACPZ), J. Prado et al. 1167 (SP, UFACPZ), J. Prado et al. 1308 (SP, UFACPZ), J. Prado et al. 1309 (SP, UFACPZ).

World Distribution: Mexico, Mesoamerica, and N South America to Bolivia.

Characterized by 1-pinnate laminae, falcate pinnae $2-3 \times$ longer than wide, and proximal pinnae flabelliform to almost round. Also distinctive are the large terminal pinna $(3.5-4.5 \times 2-4 \mathrm{~cm})$ that are asymmetrical, approximately triangular, and trilobed.

Lindsaea hemiglossa K.U. Kramer, Acta Bot. Neerl. 6(2): 257. 1957.

Figures: 27G-I

Habit/Habitat: Herb; terrestrial in forest on terra firme, on slopes.

Material examined: Cruzeiro do Sul, G.T. Prance et al. 11931 (NY); Mâncio Lima, G.T. Prance et al. 12142 (NY).

World Distribution: N South America.

Characterized by 2-pinnate laminae and terminal pinnae almost $2 \times$ longer than the lateral ones. Also distinctive are narrow pinnules $6 \times$ longer than wide, the proximal ones reduced and triangular. The terminal pinnule are flabellate, long-cuneate basally and ending in a stalk, as long as wide or wider, emarginate or concave (V-shaped) apically.

Lindsaea lancea (L.) Bedd., Suppl. Ferns S. Ind. 6. 1876. Adiantum lanceum L., Sp. Pl. (ed. 2) 2: 1557. 1763.

Figures: 27J-M

Habit/Habitat: Herb; terrestrial in forest on terra firme.

Material examined: Cruzeiro do Sul, J. Prado et al. 1309 (SP, UFACPZ).

World Distribution: S Mexico, Antilles, Mesoamerica, and tropical South America.

Characterized by leaves 1- or 2-pinnate (very rarely 3-pinnate at base), 3 or 4 pinna pairs, pinnules regularly dimidiate, semilunate, the proximal ones falcate, $2 \times$ longer than wide, the medial pinnules $3 \times$ longer than wide, and the terminal pinnule broadly lanceolate, or even triangular, asymmetrical at base, trilobed, apex sometimes caudate.

Lindsaea schomburgkii Klotzsch, Linnaea 18: 545. 1844[1845].

Figures: 28A, B

Habit/Habitat: Herb; terrestrial in forest on terra firme.

Material examined: Cruzeiro do Sul, J. Prado et al. 1172 (SP, UFACPZ).

World Distribution: N South America.

Characterized by slender (2-3 mm wide) creeping rhizomes, laminae 1-pinnate, pinnae falcate with the medial ones overlapping each other, $2.5 \times$ longer than wide, the terminal pinna flabellate, truncate, $2-3.5 \times 1.5-4 \mathrm{~cm}$ ).

Lindsaea stricta (Sw.) Dryand. var. stricta, Trans. Linn. Soc. London 3: 42. 1797. Adiantum strictum Sw., Prodr. 135. 1788.

Figures: 28C, D

Habit/Habitat: Herb; terrestrial, in Campina.

Material examined: Cruzeiro do Sul, D.C. Daly et al. 10633 (NY), J. Prado et al. 1335 (SP, UFACPZ).

World Distribution: Widespread in the Neotropics.

Characterized by nodose rhizomes, coriaceous, 2-pinnate leaves, pinnules 1-2 × longer than wide, and distal pinnules gradually reduced toward the pinna apices, becoming almost vestigial. 
Lindsaea taeniata K.U. Kramer, Acta Bot. Neerl. 6(2): 208, fig. 62.1957.

Habit/Habitat: Herb; terrestrial in forest on terra firme, on sandy soils. Material examined: Mâncio Lima, W.T. Steward P12691 (NY).

World Distribution: N South America to Bolivia.

Characterized by slender (2-3 mm diam.) creeping rhizomes, 2-pinnate leaves, pinnules patent, elongate $(3-5 \mathrm{~cm} \times 6-7 \mathrm{~mm})$, with the inner margin parallel to the rachis, proximal pinnules slightly reduced, and distal pinnules gradually reduced, terminal pinnule narrowly lanceolate, subhastate-lobed at base.

Lindsaea ulei Hieron. ex Christ, Hedwigia 44: 365. 1905.

Figures: 28E, F

Habit/Habitat: Herb; terrestrial in forest on terra firme, on sandy soils. Material examined: Cruzeiro do Sul, J. Prado et al. 1206 (SP, UFACPZ), J. Prado et al. 1356 (SP, UFACPZ); Rodrigues Alves, J. Prado et al. 1232 (SP, UFACPZ), J. Prado et al. 1243 (SP, UFACPZ), J. Prado et al. 1367 (UFACPZ), J. Prado et al. 1369 (SP, UFACPZ).

World Distribution: N South America.

Characterized by creeping, slender (2-3 mm wide) rhizomes, 1-pinnate leaves, large $(4-4.5 \times 2-2.5 \mathrm{~cm})$, falcate pinnae with apices curved toward the base of the lamina, proximal pinnae strongly falcate, terminal pinna large $(2-4 \times 4-10 \mathrm{~cm})$, asymmetrically flabellate, the distal margin convex or sinuous.

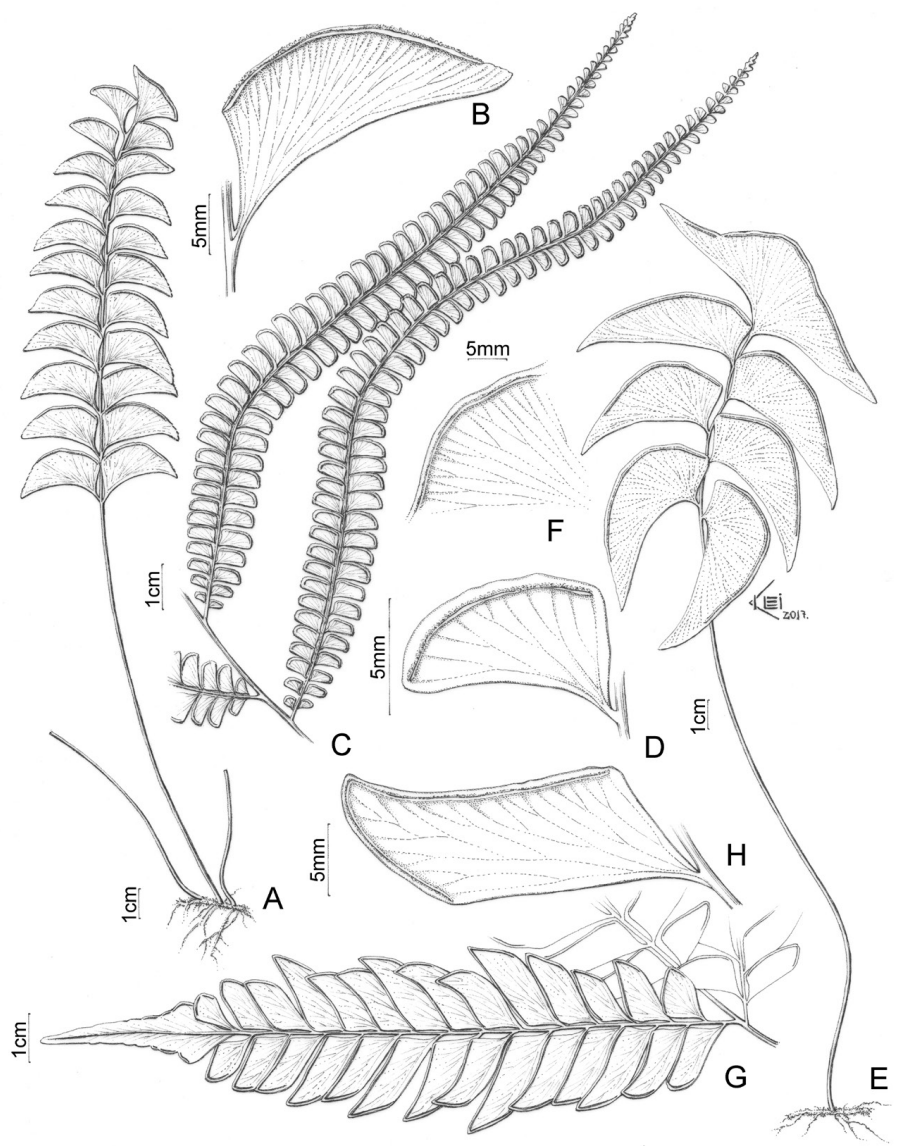

Figure 28. A, B. Lindsaea schomburgkii (Prado et al. 1172, SP). A. Habit. B. Venation of the fertile pinna. C, D. Lindsaea stricta var. stricta (Prado et al. 1335, SP) C. Pinnae. D. Venation of the fertile pinnule. E, F. Lindsaea ulei (Prado et al. 1232, SP). E. Habit. F. Detail of the veins. G, H. Lindsaea sp. (Prado et al. 1348, SP). G. Pinna. H. Venation of the fertile pinnule.

\section{Lindsaea sp}

Figures: $28 \mathrm{G}, \mathrm{H}$

Habit/Habitat: Herb; terrestrial in forest on terra firme, on clay soils. Material examined: Cruzeiro do Sul, J. Prado et al. 1348 (SP, UFACPZ). World Distribution: Peru and Brazil.

Differing from other species of Lindsaea in Acre by 2-pinnate leaves, 2-pairs of lateral pinnae, dimidiate, trapeziform pinnules, apices falcate, 2-4 $\times$ longer than wide, and strongly overlapping each other. The apices of the pinnules turn acroscopically, and the terminal pinnules are large (4-4.5 × 2-2.5 cm), asymmetrical, approximately triangular, trilobed, with long-attenuate apices. The closest species is L. phassa K.U. Kramer, but it differs mainly by the pinnules not overlapping and pinnule apices strongly long-acuminate.

\section{LOMARIOPSIDACEAE}

Characterized by long-creeping to erect, scaly rhizomes; monomorphic or dimorphic sterile and fertile leaves, 1-pinnate laminae; pinnae articulate to the rachises, and veins free; sori round or acrostichoid, indusiate or exindusiate. Variable as to habit, either terrestrial, epilithic, hemiepiphytic, or epiphytic. A member of Eupolypods I, a clade defined by having petiole vasculature with the 2 adaxial bundles enlarged and several smaller ones arranged in a semicircle beneath.

Pantropical; 5 genera, 70 species. In Acre, 2 genera, 4 species.

1. Plants scandent on tree trunks; sterile and fertile leaves dimorphic; sori acrostichoid .... Lomariopsis

1. Plants terrestrial; sterile and fertile leaves monomorphic; sori round Cyclopeltis

Cyclopeltis J. Sm., Bot. Mag. 72: 36. 1846.

Pantropical; 6 species, 1 in Acre.

Cyclopeltis semicordata (Sw.) J. Sm., Bot. Mag. 72: comp. 36. 1846. Polypodium semicordatum Sw., Prodr. 132. 1788.

Figures: 29A, B

Habit/Habitat: Herb; terrestrial in forest on terra firme, on sandy soils. Material examined: Cruzeiro do Sul, D.C. Daly et al. 11721 (NY); Manoel Urbano, D.C. Daly et al. 11427 (NY), M. Silveira et al. 1574 (NY); Marechal Thaumaturgo, D.C. Daly et al. 7342 (NY, UFACPZ), D.C. Daly et al. 10473 (NY), D.C. Daly et al. 10810 (NY); Porto Acre, C.A. Cid \& B. Nelson 2877 (NY), P.J.M. Maas et al. 13247 (MG, NY); Quixadá, C.A Cid \& A. Rosas Jr. 2961 (NY); Reserva Extrativista Chico Mendes, Colocação Simitumba, A.R.S. Oliveira et al. 131 (NY, UFACPZ); Rio Branco, C.S. Pessôa et al. 194 (RB); Santa Rosa, D.C. Daly et al. 10978 (NY), D.C. Daly et al. 11367 (NY); Sena Madureira, D.C. Daly et al. 7857 (NY, UFACPZ); Rio Branco, D.C. Daly et al. 6881 (NY, UFACPZ); Tarauacá, D.C. Daly et al. 8667 (NY, UFACPZ), D.C. Daly et al. 8799 (NY, UFACPZ), G.T. Prance et al. 7516 (NY); Xapuri, D.C. Daly et al. 8420 (NY); Without locality, J. Jangoux et al. 85-074 (MG, NY).

World Distribution: S Mexico, Antilles, Mesoamerica, and N South America to Bolivia.

Characterized by 1-pinnate leaves and pinnae with the basiscopic base auricled, with the auricle overlapping the rachis. Other helpful characters are subconform lamina apices, pinnae articulate to the rachises (the articulation seen as a faint dark line; magnification needed), entire or nearly so, sori round, in 2 or 3 rows between the costa and margin, and indusia peltate. A common species in Acre and the only Neotropical species of the genus.

Lomariopsis Fée, Mém. Foug. 2: 10-12. 1845.

Plants hemiepiphytic, starting from gametophytes around the bases of tree trunks. Rhizomes long-creeping, in cross section with a broad ventral 
meristele, roots borne only on the ventral surfaces; sterile and fertile leaves strongly dimorphic; petioles not articulate to the rhizome, with 4-8 vascular bundles; laminae 1-pinnate (simple in juveniles of some species), with a conform apical pinna; pinnae entire or nearly so, articulate to the rachis; fertile pinnae narrower than the sterile; sori acrostichoid. The Neotropical species were revised by Moran (2000).

Pantropical; 60 species, 3 in Acre.

1. Rhizome scales reddish or reddish brown L. prieuriana

1. Rhizome scales dark brown to black

2. Rhizome scales $1-2.5 \mathrm{~mm}$ long; laminae only slightly reduced toward the base

L. nigropaleata

2. Rhizome scales $2-10 \mathrm{~mm}$ long; laminae gradually reduced toward the base

L. japurensis

Lomariopsis japurensis (Mart.) J. Sm., Hist. Fil. 140. 1875. Acrostichum japurense Mart., Icon. Pl. Crypt. 86, tab. 24. 1834.

Figures: $29 \mathrm{C}-\mathrm{F}$

Habit/Habitat: Herb; hemiepiphyte, in terra firme forest.

Material examined: Assis Brasil, D.C. Daly et al. 9817 (NY, UFACPZ); Cruzeiro do Sul, P.J.M. Maas et al. P12886 (NY); Mâncio Lima, G.T. Prance et al. 12055 (NY); Marechal Thaumaturgo, L.G. Lohmann et al. 480 (NY); Santa Rosa, D.C. Daly et al. 9945 (NY).

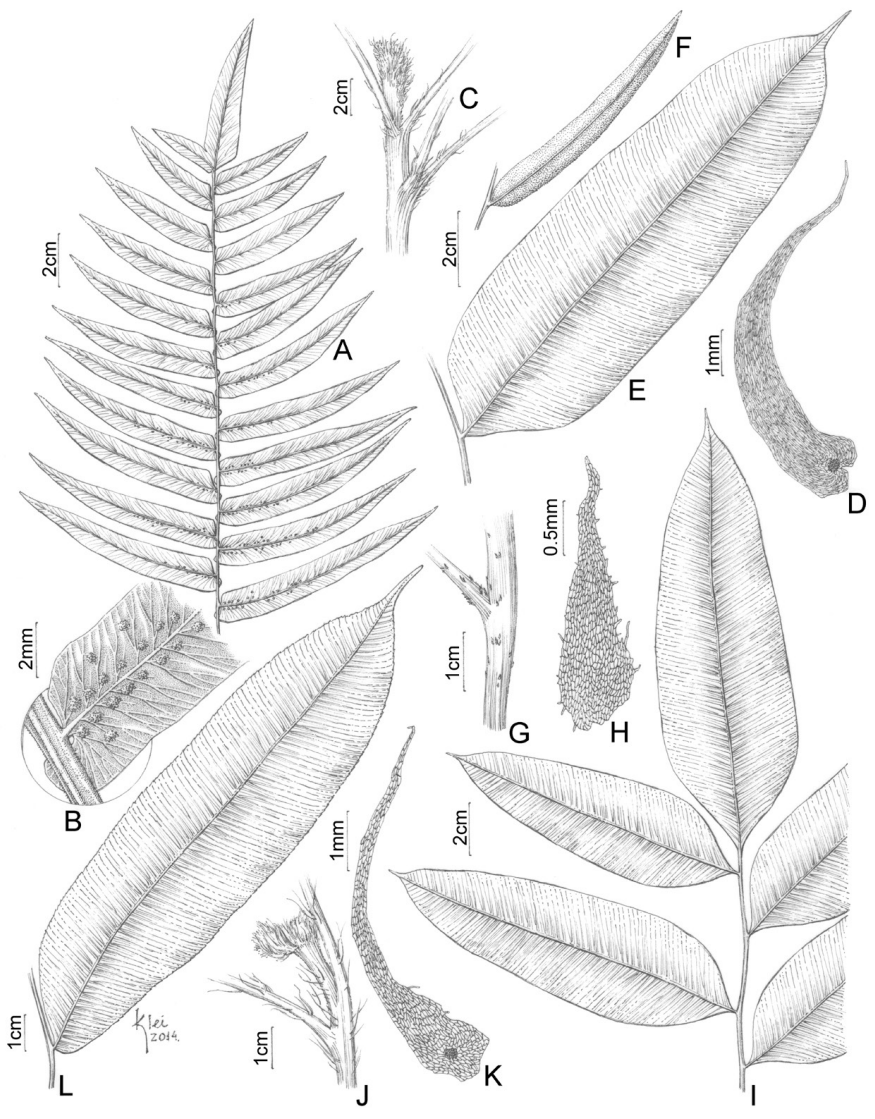

Figure 29. A, B. Cyclopeltis semicordata (Daly et al. 8420, NY). A. Fertile frond. B. Venation of the fertile pinna. C-F. Lomariopsis japurensis. C. detail of stem. D. Stem scale. E. Sterile pinna (C-E. Prance et al. 12055, NY). F. Fertile pinna (Maas et al. 12886, NY). G-I. Lomariopsis nigropaleata (Prado et al. 1352, SP). G. Stem. H. Stem scale. I. Part of a sterile frond. J-L. Lomariopsis prieuriana (Prado et al. 1137, SP). J. Stem. K. Stem scale. L. Sterile pinna.
World Distribution: Mesoamerica and N South America to Bolivia. Characterized by laminae gradually reduced toward the base.

Lomariopsis nigropaleata Holttum, Bull. Misc. Inform. Kew 1939: 618. 1940.

Figures: 29G-I

Habit/Habitat: Herb; hemiepiphyte, in terra firme forest.

Material examined: Brasiléia, S.R. Lowrie et al. 726 (NY); Cruzeiro do Sul, J. Prado et al. 1202 (SP, UFACPZ), J. Prado et al. 1211 (SP, UFACPZ), J. Prado et al. 1352 (SP, UFACPZ); Mâncio Lima, D.C. Daly et al. 11568 (NY); Marechal Thaumaturgo, L.C. Ming \& L.A. Ferreira 324 (NY).

World Distribution: N South America to Bolivia.

Characterized by small (1-2.5 mm long), appressed, black rhizome scales and cuneate pinna bases.

Lomariopsis prieuriana Fée, Mém. Foug. 2: 66, tab. 25, fig. 1. 1845.

Figures: 29J-L

Habit/Habitat: Herb; hemiepiphyte, in terra firme forest.

Material examined: Mâncio Lima, J. Prado et al. 1137 (SP, UFACPZ); Rodrigues Alves, J. Prado et al. 1363 (SP, UFACPZ).

World Distribution: Mesoamerica and N South America to Bolivia.

Characterized by pinnae oblong with bases excavate basiscopically. Compared to the other two congeners in Acre, the rhizome scales are brighter reddish or reddish brown.

\section{LYGODIACEAE}

Characterized by twining rachises. The only other fern genus with climbing rachises is Salpichlaena (Blechnaceae), which differs by reddish young leaves that are 2-pinnate, and linear sori parallel to the costules. Petioles in cross-section with a single circular vascular bundle. No angiosperm climbs by means of a twining rachis.

Also characterized by creeping rhizomes bearing leaves in a single row on the dorsal surface (orthostichous), branching dichotomously at the apex, pubescent; leaves indeterminate, the rachises twining around a support; pinnae alternate, short-stalked, the stalks forked and often with a bud in the bifurcation; veins free or areolate; sori borne marginally on the lobes, often in small finger-like projections (sorophores), but in some species the entire fertile segment is narrowed; sporangia solitary, one per vein tip, each sporangium covered by a green flap of tissue.

Pantropical; 1 genus, ca. 40 species.

Lygodium Sw., J. Bot. (Schrader) 1800(2): 7, 106. 1801, nom. cons. Same characters as those given for the family. 2 species in Acre.

1. Sterile pinnules lobed at base; axes densely pubescent ... L. venustum

1. Sterile pinnules entire; axes sparsely puberulent L. volubile

Lygodium venustum Sw., J. Bot. (Schrader) 1801(2): 304. 1803.

Figures: $30 \mathrm{~A}-\mathrm{C}$

Habit/Habitat: Herb; vine-like, in forest on terra firme.

Material examined: Manoel Urbano, M. Silveira et al. 1543 (NY, UFACPZ); Rio Branco, L. Coêlho \& A. Rosas Jr. 1925 (NY); Tarauacá, C. Ehringhaus et al. 346 (NY).

World Distribution: Mexico, Antilles, Mesoamerica, and tropical South America.

Characterized by densely pubescent leaf axes and basally lobed sterile pinnules.

Lygodium volubile Sw., J. Bot. (Schrader) 1801(2): 303. 1803.

Figures: 30D-F 
Prado, J. et al.

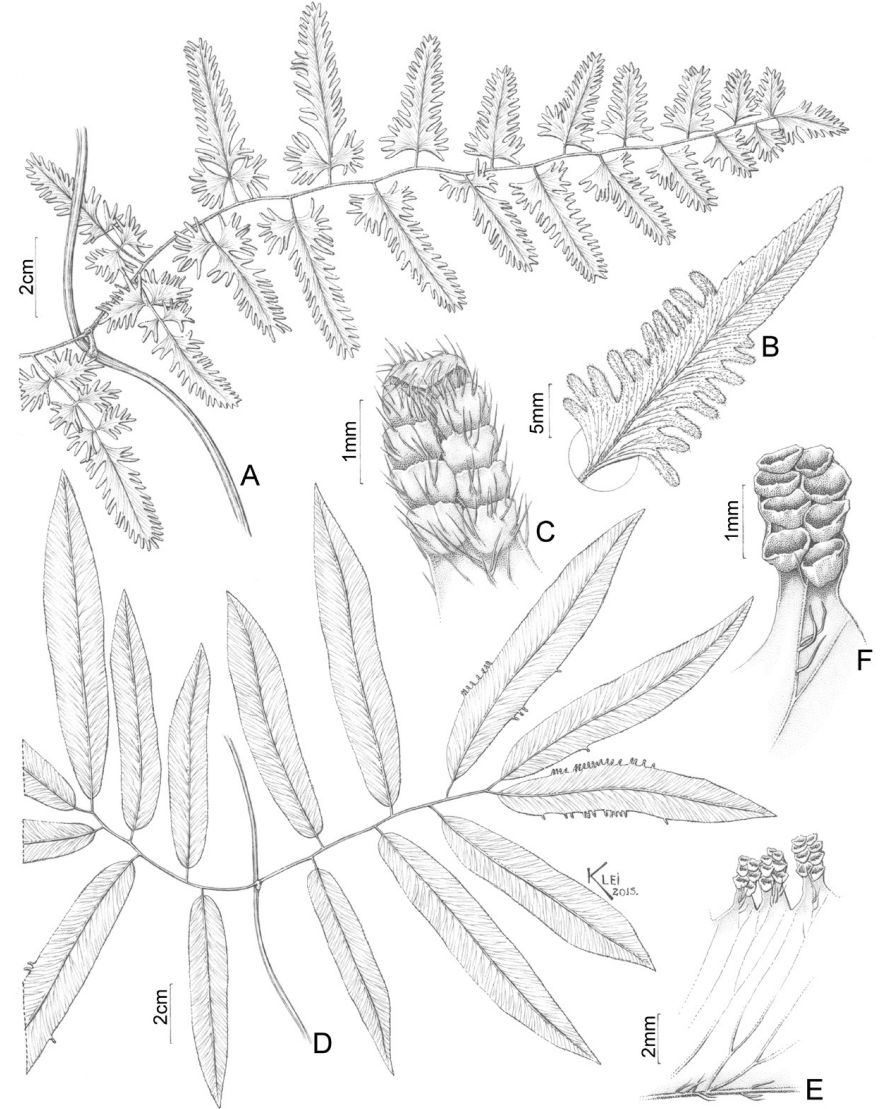

Figure 30. A-C. Lygodium venustum (Coêlho \& Rosas 1925, NY). A. Part of a frond. B. Fertile pinnule. C. Sori. D-F. Lygodium volubile (Prado et al. 1371, SP). D. Part of a frond. E. Part of a fertile pinnule. F. Sori.

Habit/Habitat: Herb; vine-like, in forest on terra firme.

Material examined: Cruzeiro do Sul, J. Prado et al. 1371 (SP, UFACPZ).

World Distribution: Mexico, Antilles, Mesoamerica, and tropical South America.

Characterized by basally rounded (not lobed) sterile pinnules, and axes nearly glabrous or sparsely puberulent.

\section{MARATTIACEAE}

Characterized by 2 paired, fleshy, ear-like stipules at the base of the leaves, swellings (pulvinuloids) present on the pinna bases or (in Danaea) along the rachises where the pinnae are joined, opposite pinnae, and synangia. The petioles with 2 or more concentric rings of separate vascular bundles. All member of the family exude mucilage from the cut surfaces of the roots, stems, and leaves.

Pantropical; 6 genera, ca. 111 species. In Acre, 1 genus, 3 species.

Danaea Sm., Mém. Acad. Roy. Sci. (Turin) 5(1790-1791): 420, tab. 9 , fig. 11. 1793, nom. cons.

Easily recognized by fresh rhizomes that are pinkish-purple when cut, 1-pinnate leaves with a conform terminal segment (this sometimes replaced by a bud), opposite pinnae, and rachises swollen at the point of pinna attachment. Other distinctive characteristics are dimorphic sterile and fertile leaves; petioles with or without swollen nodes, basally with rounded, earlike, fleshy stipules; pinnae entire or with serrate apices; rachises swollen-nodose at the insertion of the pinnae; veins free, simple or 1 -forked near the base, parallel to each other; fertile leaves long-petiolate and therefore taller than the sterile, with narrower pinnae; sporangia fused into double-rowed synangia, opening by pores; synangia covering almost the entire lamina abaxially.

Neotropical; ca. 50 species, 3 in Acre.

1. Sterile pinna pairs 1 D. trifoliata

1. Sterile pinna pairs $3-10$

2. Petioles without nodes; sterile pinna pairs 4-10, 20-35 cm long.... D. cartilaginea

2. Petioles with 2 or 3 nodes; sterile pinna pairs $3-5,11-15 \mathrm{~cm}$ long. D. leprieurii

Danaea cartilaginea Christenh. \& Tuomisto, Kew Bull. 61(1): 18, 21-23, f. 3A-E. 2006.

Figures: $31 \mathrm{C}-\mathrm{E}$

Habit/Habitat: Herb; terrestrial in forest on terra firme.

Material examined: Brasiléia, D.C. Daly et al. 6787 (NY, UFACPZ), D.C. Daly et al. 9884 (NY, UFACPZ); Feijó, P. Delprete et al. 8301A \& B (NY); Sena Madureira, D.C. Daly et al. 8137 (NY, UFACPZ); Without municipality, J. Jangoux et al. 85-071 (NY).

World Distribution: Venezuela, Colombia, Ecuador, Peru and Brazil.

Characterized by the absence of nodes on the petioles, and laminae with 4-10 pairs of lateral pinnae, these elliptic, lanceolate to oblanceolate, $20-35 \mathrm{~cm}$ long, margins cartilagineous, and apices varying from entire to denticulate, the dentation usually not cutting into the green laminar tissue.

Danaea leprieurii Kunze, Farrnkräuter 1: 37, fig. 60. 1843.

Figures: 31A, B

Habit/Habitat: Herb; terrestrial in forest on terra firme, near stream margins.

Material examined: Cruzeiro do Sul, J. Prado et al. 1204 (SP, UFACPZ).

World Distribution: S Mexico, Antilles, Mesoamerica, and N South America.

Characterized by erect rhizomes and 3-5 pairs of elliptic pinnae $11-15 \mathrm{~cm}$ long.

Danaea trifoliata Reichb. ex Kunze, Analecta Pteridogr. 4, tab. 2. 1837.

Figures: $31 \mathrm{~F}, \mathrm{G}$

Habit/Habitat: Herb; terrestrial in forest on terra firme, near stream margins.

Material examined: Rodrigues Alves, J. Prado et al. 1365 (SP, UFACPZ).

World Distribution: Guianas and Brazil.

Characterized by ternate leaves with the terminal pinnae at least 2-3 $\times$ longer than the lateral ones.

\section{METAXYACEAE}

Characterized by short-creeping, pubescent rhizomes, 1-pinnate leaves with a conform terminal segment, and non-indusiate sori scattered near the costae. Also distinctive are leaves to $2.5(-3.6) \mathrm{m}$ long, the sterile and fertile ones monomorphic; petioles with a single corrugated horseshoe-shaped vascular bundle; pinnae alternate, stalked, entire, serrate distally; veins free, parallel to each other, simple or bifurcate at the base; sori superficial (not marginal), without indusia, scattered close to the costa, 1-3 on each vein; paraphyses filiform; receptacles flat (not elevated).

This family belongs to the tree fern clade, Cyatheales, but it is not arborescent.

Neotropical; 1 genus, 6 species (Cárdenas et al. 2016). In Acre, 1 species.

Metaxya C. Presl, Tent. Pterid. 59. 1836.

Characters of the family. 


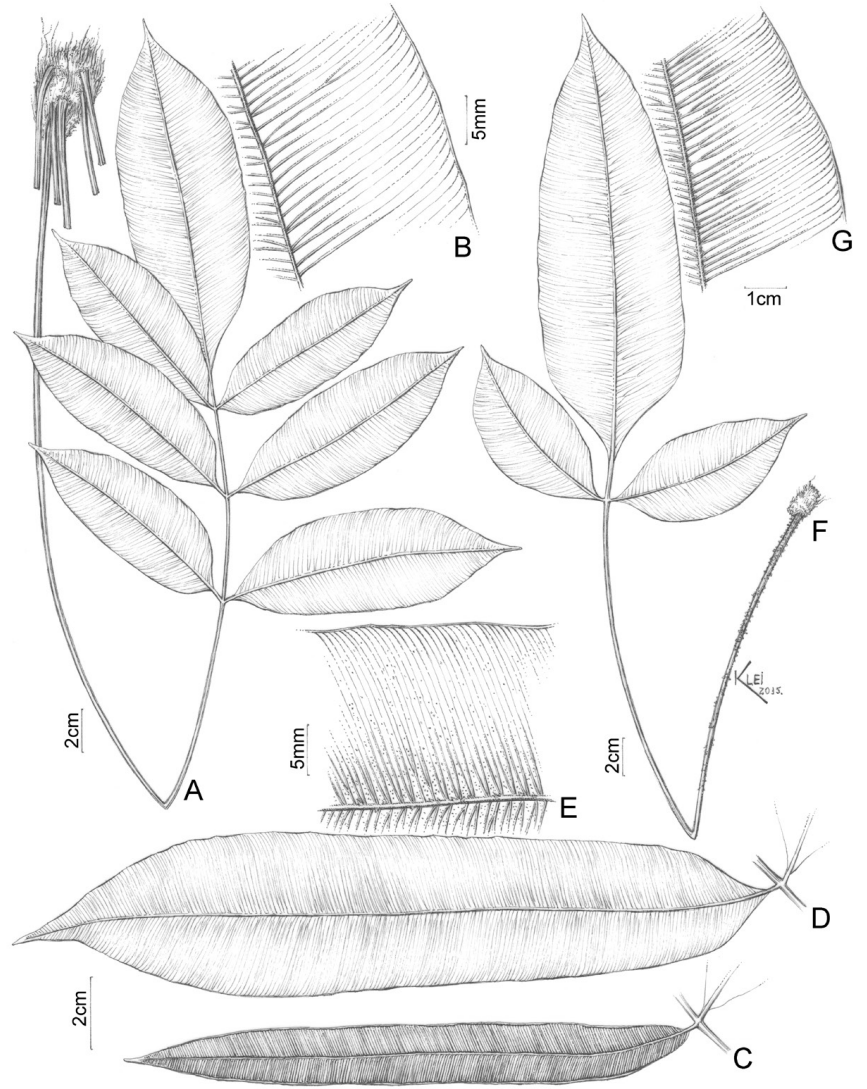

Figure 31. A, B. Danaea leprieurii (Prado et al. 1204, SP). A. Habit. B. Venation. C-E. Danaea cartilaginea (Jangoux et al. 85-071, NY). C. Fertile pinna. D. Sterile pinna. E. Venation. F, G. Danaea trifoliata (Prado et al. 1365, SP). F. Habit. G. Venation.

Metaxya parkeri (Hook. \& Grev.) J. Sm., London J. Bot. 1: 668. 1842. Polypodium parkeri Hook. \& Grev., Icon. Fil. 2: tab. 232. 1831.

Figures: $32 \mathrm{~A}-\mathrm{J}$

Habit/Habitat: Herb; terrestrial in forest on terra firme, near stream margins.

Material examined: Cruzeiro do Sul, D.C. Daly et al. 11705 (NY), J. Prado et al. 1186 (SP, UFACPZ), J. Prado et al. 1301 (SP, UFACPZ), J. Prado et al. 1320 (SP, UFACPZ); Mâncio Lima, D.C. Daly et al. 11624 (NY), M. Silveira et al. 1365 (NY); Marechal Thaumaturgo, D.C. Daly et al. 10526 (NY); Porto Valter, D.C. Daly et al. 7577 (NY), P.J.M. Maas et al. P13150 (NY); Without locality, J. Jangoux et al. 85-043 (NY), J. Jangoux et al. 85-108 (NY).

World Distribution: Lesser Antilles, mainly N South America To Bolivia.

Compared to its congeners, Metaxya parkeri is unique by serrations of the pinnae not restricted to the apices, but instead extending toward the pinna base at least one-quarter of the way, and sometimes all the way, to the base. Congeners have either entire pinnae or ones that are serrate only apically.

\section{NEPHROLEPIDACEAE}

Characterized by the presence of stolons, 1-pinnate laminae typically with a small fiddlehead at the apex, sessile pinnae, and round sori. The rachis scales are unique among ferns in that the acute elongated side points toward the base of the leaf, not the apex as in the scales on the petiole bases and rhizomes. The petioles contain several vascular bundles, the 2 adaxial ones enlarged and subtended by a semi-circle of smaller ones (i.e., typical Eupolypods I pattern). Further characterized by erect, usually short stems, these scaly,

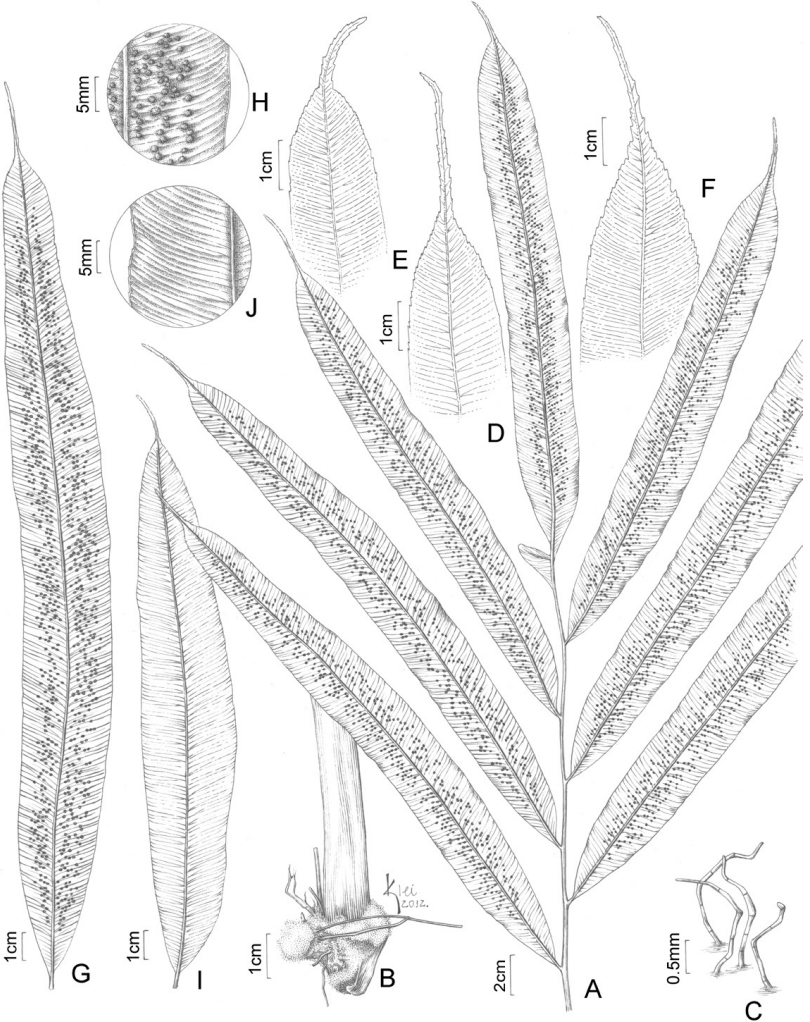

Figure 32. A-J. Metaxya parkeri. A. Part of a fertile frond. B. Petiole base. C. Hairs from the petiole base (A-C. Prado et al. 1186, SP). D-F. Variation of the pinna apex (Prado et al. 1186, 1320, 1301, respectively, all from SP). G. Abaxial view of a fertile pinna. H. Fertile veins with sori (G, H. Prado et al. 1186, SP). I. Abaxial view of a sterile pinna. J. Sterile veins (I, J. Prado et al. 1320, SP).

the scales peltate; sterile and fertile leaves monomorphic; laminae linear to linear-oblong; pinnae numerous, articulate to the rachis by a circular abscission zone; veins free, adaxially hydathodous, the hydathodes often white; sori terminal on the first acroscopic vein branch, in a single row between the costa and pinna margin, medial to submarginal; indusia lunate to circular, attached by a sinus.

Pantropical; 1 genus, ca. 19 species, 4 in Acre.

Nephrolepis Schott, Gen. Fil. tab. 3. 1834.

Same characters as the family.

1. Indusia lunate, broader than wide

N. pendula

1. Indusia reniform, approximately circular

2. Pinnae adaxially sparsely scaly, the scales whitish and ciliate; petiole scales bicolorous with a dark center and lighter-colored borders

N. brownii

2. Pinnae adaxially glabrous; petiole scales concolorous

3. Pinnae abaxially scaly; indusia bicolorous, darkened centrally with lighter margins

N. rivularis

3. Pinnae abaxially pubescent; indusia concolorous, not darkened centrally

N. biserrata

Nephrolepis biserrata (Sw.) Schott, Gen. Fil. tab. 3. 1834. Aspidium biserratum Sw., J. Bot. (Schrader) 1800(2): 32. 1801.

Figures: 33A, B 


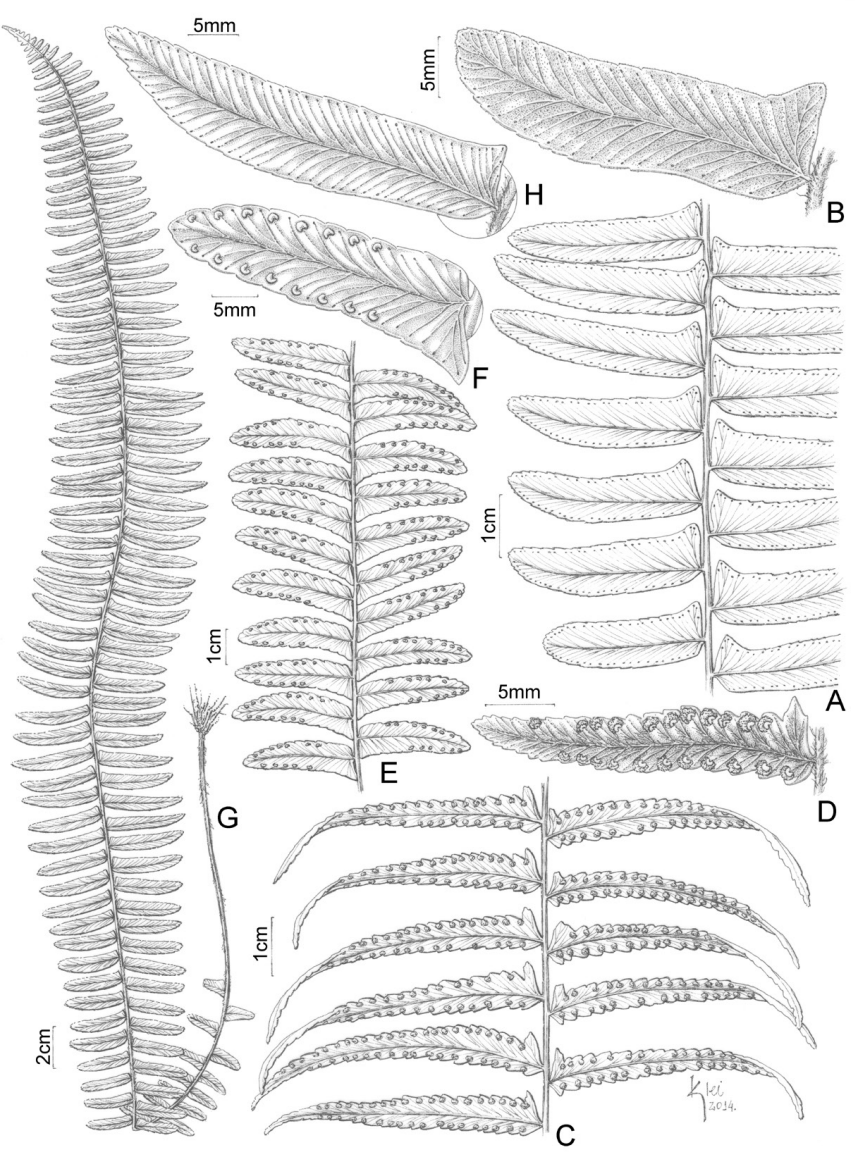

Figure 33. A, B. Nephrolepis biserrata (Prado et al. 1163, SP). A. Part of a sterile frond. B. Venation of a sterile pinna. C, D. Nephrolepis brownii (Delprete et al. 8111, NY). C. Part of a fertile frond. D. Venation and sori of the fertile pinna. E, F. Nephrolepis pendula (Prance et al. 7296, NY). E. Part of a fertile frond (epiphyte and pendant). F. Venation and sori of the fertile pinna. G, H. Nephrolepis rivularis (Prado et al. 1286, SP). G. Habit. H. Venation of the sterile pinna.

Habit/Habitat: Herb; epiphyte in forest on terra firme near stream margins. Material examined: Cruzeiro do Sul, J. Prado et al. 1163 (SP, UFACPZ), J. Prado et al. 1180 (SP, UFACPZ), J. Prado et al. 1199 (SP, UFACPZ); Mâncio Lima, J. Prado et al. 1216 (SP, UFACPZ).

World Distribution: Florida, Mexico, Antilles, Mesoamerica, tropical South America.

Characterized by pinnae pubescent abaxially and glabrous adaxially, and by reniform indusia.

Nephrolepis brownii (Desv.) Hovenkamp \& Miyam., Blumea 50(2): 293. 2005. Nephrodium brownii Desv., Mém. Soc. Linn. Paris 6: 252. 1827.

Figures: 33C, D

Habit/Habitat: Herb; epiphyte in forest on terra firme near stream margins.

Material examined: Cruzeiro do Sul, P. Delprete et al. 8111 (NY); Mâncio Lima, D.C. Daly et al. 11595 (NY).

World Distribution: Florida, S Mexico, Antilles, Mesoamerica, tropical South America, Paleotropics.

No other species of Nephrolepis has bicolorous petiole scales. These are often appressed, whereas in other species they are spreading. Also distinctive by reniform indusia and pinna adaxially with sparse, whitish, ciliate scales.

Nephrolepis pendula (Raddi) J. Sm., J. Bot. (Hooker) 4: 197. 1841[1842]. Aspidium pendulum Raddi, Opusc. Sci. 3: 289. 1819.
Figures: 33E, F

Habit/Habitat: Herb; epiphyte on terra firme.

Material examined: Tarauacá, G.T. Prance et al. 7296 (NY).

World Distribution: S Mexico, Mesoamerica, and N South America to Bolivia.

Characterized by glabrous leaves (rachis, veins, and laminar tissue), sori submarginal, and indusia much broader than long.

Nephrolepis rivularis (Vahl) Mett. ex Krug, Bot. Jahrb. Syst. 24: 122. 1897. Polypodium rivulare Vahl, Eclog. Amer. 3: 51. 1807.

Figures: $33 \mathrm{G}, \mathrm{H}$

Habit/Habitat: Herb; epiphyte on várzea forest.

Material examined: Cruzeiro do Sul, J. Prado et al. 1286 (SP, UFACPZ), J. Prado et al. 1325 (SP, UFACPZ); Mâncio Lima, G.T. Prance et al. 12179 (MG, NY).

World Distribution: S Mexico, Antilles, Mesoamerica, and N South America to Bolivia.

Characterized by circular bicolorous indusia (darker center, pale borders) and pinna adaxially glabrous. Abaxially, the pinnae have minute, basally ciliate scales.

\section{POLYPODIACEAE}

Characterized by epiphytic habit, creeping rhizomes bearing 2 dorsolateral rows of phyllopodia; simple to 1-pinnate leaves (seldom highly dissected) to 2-pinnate-pinnatisect; round sori, and either yellow or green spores. Petioles with 1 or 2 vascular bundles (grammitids, which are not in Acre) or with several to many vascular bundles with the 2 adaxial ones enlarged and subtended by a semicircle of smaller ones (Eupolypods I pattern); sori round or oblong, or linear, exindusiate or protected by a scale.

It is one of the largest families in ferns. About half the species in the family are the "grammitid ferns", characterized by lack of laminar scales and green tetrahedral spores. This clade, which is primarily montane, is absent from Acre

Cosmopolitan; 65 genera, ca. 1,652 species. In Acre, 7 genera, 30 species.

1. Leaves simple, entire

2. Sori linear

Pleopeltis

2. Sori round

3. Sori in several rows between midrib and lamina margin

4. Sori in 2 or more rows between the main lateral veins running from midrib to margin

Campyloneurum

4. Sori in 1 row between the main lateral veins running from midrib to margin

Niphidium

3. Sori in 1 row between rachis and lamina margin

5. Rhizome scales clathrate; sori covered by peltate scales when young

Pleopeltis

5. Rhizome scales not clathrate; sori not covered by peltate scales

Microgramma

1. Leaves pinnatisect to (rarely) 2-pinnate-pinnatisect

6. Rachises adaxially puberulent; sporangial capsules often setulose; rhizome scales often with brown hairs at the point of attachment ...

Pecluma

6. Rachises adaxially glabrous; sporangial capsules glabrous; rhizome scales glabrous 
7. Laminae moderately to densely scaly; sori when young covered by peltate scales Pleopeltis

7. Laminae glabrous or nearly so; sori when young not covered by peltate scales

8. Leaves pinnatifid, the apical segment conform (i.e., resembling the lateral pinnae); sori typically supplied by two veins

Phlebodium

8. Leaves pinnatifid or 1-pinnate; the apices gradually tapered and pinnatifid; sori supplied by a single vein Serpocaulon

Campyloneurum C. Presl, Tent. Pterid. 189. 1836.

Characterized by rhizomes short- to long-creeping, scaly, the scales usually lanceolate, clathrate or non-clathrate, glabrous; sterile and fertile leaves monomorphic; petioles articulate to the rhizomes or to short phyllopodia; laminae simple, entire (but 1-pinnate in 2 species), oblong to narrowly elliptic, glabrous or with a few scales on the rachis; venation areolate with included veinlets, these usually between prominent veins; sori in 2-4 rows between the main lateral veins, borne on the tips of included veinlets, round, and several rows between the midrib and margins of the lamina; sporangia glabrous; paraphyses absent. Mostly epiphytic, occasionally terrestrial or rupiculous.

Neotropical; ca. 55 species, 7 in Acre.

1. Laminae $0.5-1.2 \mathrm{~cm}$ wide . C. angustifolium

1. Laminae $2-12 \mathrm{~cm}$ wide

2. Rhizomes 6-15 mm wide

3. Laminae abruptly decurrent to a narrow wing along petioles ...... C. abruptum

3. Laminae gradually tapering toward the base C. phyllitidis

2. Rhizomes $1-4(-5) \mathrm{mm}$ wide

4. Laminae $5-10 \mathrm{~cm}$ wide C. coarctatum

4. Laminae $2-4 \mathrm{~cm}$ wide

5. Laminae minutely puberulent abaxially (magnification needed); rhizomes short-creeping, nodose; petioles $2 \mathrm{~mm}$ apart C. aphanophlebium

5. Laminae glabrous abaxially; rhizomes long-creeping; petioles $7-15 \mathrm{~mm}$ apart

6. Rhizome scales slightly bicolorous, with dark centers and lighter brown margins C. repens

6. Rhizome scales concolorous C. fuscosquamatum

Campyloneurum abruptum (Lindm.) B. Léon, Fieldiana, Bot., n.s. 32: 172. 1993. Polypodium repens var. abruptum Lindm., Ark. Bot. 1: 245. 1903.

Habit/Habitat: Herb; epiphyte, várzea forest.

Material examined: Manoel Urbano, D.C. Daly et al. 11225 (NY), M. Silveira et al. 1582 (NY).

World Distribution: N South America to Bolivia.

Characterized by laminae $6-8 \mathrm{~cm}$ wide and abruptly decurrent toward the base, and stout rhizomes ca. $1 \mathrm{~cm}$ wide.

Campyloneurum angustifolium (Sw.) Fée, Mém. Foug. 5: 257. 1852. Polypodium angustifolium Sw., Prodr. 130. 1788.

Figure: $34 \mathrm{C}$

Habit/Habitat: Herb; epiphyte in forest on terra firme.
Material examined: Bujari, L.R. Marinho 163 (NY), M. de Pardo et al. 93 (NY); Cruzeiro do Sul, G.T. Prance et al. 12617 (NY); Feijó, P. Delprete et al. 8311 (NY); Marechal Thaumaturgo, D.C. Daly et al. 10936 (NY); Porto Valter, P.J.M. Maas et al. 12931 (NY); Tarauacá, D.C. Daly et al. 8628 (NY, UFACPZ), G.T. Prance et al. 7384 (NY), G.T. Prance et al. 7249 (NY), M. Silveira et al. 1146 (NY).

World Distribution: S Mexico, Lesser Antilles, Mesoamerica, and tropical South America.

Characterized by pendent epiphytic habit, short-creeping rhizomes, and coriaceous, linear laminae $0.3-1.0 \mathrm{~cm}$ wide. The plant illustrated in Fig. $34 \mathrm{C}$ has very narrow laminae. More study is needed on variation in this species throughout its distribution.

Campyloneurum aphanophlebium (Kunze) T. Moore, Index Filic. 223. 1861. Polypodium aphanophlebium Kunze, Bot. Zeitung (Berlin) 3(17): 288. 1845.

Figures: 34D, E

Habit/Habitat: Herb; low-trunk epiphyte, forests in broad, meandering stream valleys in steep, hilly terrain.

Material examined: Brasiléia, G.P. da Silva et al. 173 (NY); Mâncio Lima, D.C. Daly et al. 11601 (NY); Marechal Thaumaturgo, D.C. Daly et al. 7496 (NY, UFACPZ), D.C. Daly et al. 10255 (NY); Porto Valter, P.J.M. Maas et al. P13181 (NY); Rodrigues Alves, J. Prado et al. 1261 (SP, UFACPZ); Santa Rosa, D.C. Daly et al. 10173 (NY); Tarauacá, D.C. Daly et al. 8630 (NY, UFACPZ), G.T. Prance et al. 7267 (NY).

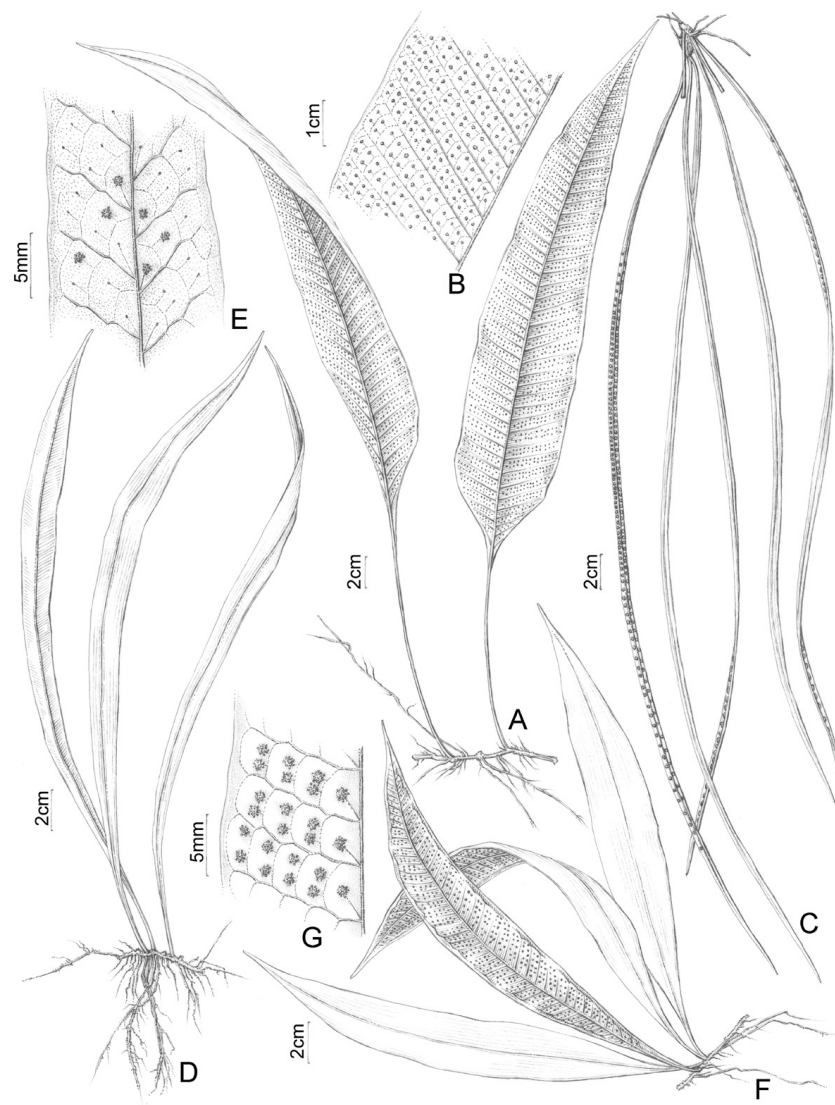

Figure 34. A, B. Campyloneurum coarctatum (Croat 85144, NY). A. Habit. B. Fertile frond. C. Campyloneurum angustifolium (Pardo et al. 93, NY). C. Habit. D, E. Campyloneurum aphanophlebium (Prado et al. 1261, SP). D. Habit. E. Fertile frond. F, G. Campyloneurum fuscosquamatum (Daly et al. 10994, NY). F. Habit. G. Sterile frond. 
World Distribution: Mesoamerica and N South America to Bolivia.

The only species of Campyloneurum in Acre with laminae pubescent abaxially. Magnification needed to see the minute hairs, which are best seen in profile. The laminae widest above the middle and long-decurrent, running nearly to the base of the leaf, leaving a very short or no petiole. The rhizomes are short-creeping with petioles ca. $2 \mathrm{~mm}$ apart.

Campyloneurum coarctatum (Kunze) Fée, Mém. Foug. 5: 258. 1852. Polypodium coarctatum Kunze, Linnaea 9: 39. 1834.

Figures: 34A, B

Habit/Habitat: Herb; epiphyte in forest on terra firme.

Material examined: Marechal Thaumaturgo, D.C. Daly et al. 10345 (NY); Porto Valter, T.B. Croat 85144 (NY), D.C. Daly et al. 7556 (NY).

World Distribution: Mesoamerica and N South America to Bolivia.

Characterized by long-creeping rhizomes with internodes $7-25 \mathrm{~mm}$ long, petioles 5-20 cm long bearing appressed, brown, marginate scales, and caudate laminae.

Campyloneurum fuscosquamatum Lellinger, Amer. Fern J. 78(1): 21, fig. 4, 10. 1988.

Figures: 34F, G

Habit/Habitat: Herb; epiphyte on terra firme forest and várzea forest. Material examined: Brasiléia, D.C. Daly et al. 6802 (NY, UFACPZ), D.C. Daly et al. 11894 (NY); Bujari, W.R. Anderson 12123 (NY); Feijó, P. Delprete et al. 8580 (NY); Cruzeiro do Sul, J. Prado et al. 1290 (SP, UFACPZ), J. Prado et al. 1338 (SP, UFACPZ); Mâncio Lima, J. Prado et al. 1141 (SP, UFACPZ), G.T. Prance et al. 12052 (MG, NY), G.T. Prance et al. 12052A (NY); Quixadá, E. Forero et al. 6388 (MG, NY); Santa Rosa, D.C. Daly et al. 10151 (NY), D.C. Daly et al. 10994 (NY); Sena Madureira, D.C. Daly et al. 7856 (NY, UFACPZ), G.T. Prance et al. 7694 (NY); Tarauacá, D.C. Daly et al. 8620 (NY, UFACPZ), D.C. Daly et al. 8760 (NY, UFACPZ); Without locality, $J$. Jangoux et al. 85-039 (MG, NY).

World Distribution: N South America to Bolivia.

Characterized by slender, long-creeping rhizomes with non-clathrate, dark brown, non-marginate, lanceolate to linear scales. The leaves are 15-28 cm long, lanceolate, and equally attenuate toward the base and apex. Greatly resembling Campyloneurum repens, differing only by concolorous rhizome scales. More study needed.

Campyloneurum phyllitidis (L.) C. Presl, Tent. Pterid. 190. 1836. Polypodium phyllitidis L., Sp. P1. 2: 1083-1084. 1753.

Figures: $35 \mathrm{~A}-\mathrm{D}$

Habit/Habitat: Herb; epiphyte in forest on terra firme.

Material examined: Brasiléia, D.C. Daly et al. 11922 (NY); Bujari, M. de Pardo et al. 94 (NY); Cruzeiro do Sul, D.C. Daly et al. 11716 (NY), J. Prado et al. 1315 (SP, UFACPZ), J. Prado et al. 1377 (SP, UFACPZ), G.T Prance et al. 2783 (NY), G.T. Prance et al. 2818 (NY), G.T. Prance et al. 12530 (NY), G.T. Prance et al. 12622 (MG, NY); Feijó, G.T. Prance et al. 7317 (NY); Mâncio Lima, J. Prado et al. 1136 (SP, UFACPZ), J. Prado et al. 1142 (SP, UFACPZ), J. Prado et al. 1215 (SP, UFACPZ); Manoel Urbano, D.C. Daly et al. 9129 (NY); Marechal Thaumaturgo, D.C. Daly et al. 10528 (NY); Porto Acre, A.R.S. Oliveira et al. 763 (NY); Porto Valter, P.J.M. Maas et al. P12932 (MG, NY); Rodrigues Alves, J. Prado et al. 1264 (SP, UFACPZ), J. Prado et al. 1280 (SP, UFACPZ); Sena Madureira, D.C. Daly et al. 7906 (NY, UFACPZ); Without locality, J. Jangoux et al. 85-098 (NY).

World Distribution: S Florida, Mexico, Antilles, Mesoamerica, and tropical and subtropical South America.

Characterized by the laminae subcoriaceous, shiny, gradually tapering toward the base, and acute apices. The rhizome scales are ovate-lanceolate, acute, and brown. Based on the number of collections, this is the most common species of Campyloneurum in Acre.

Campyloneurum repens (Aubl.) C. Presl, Tent. Pterid. 190. 1836. Polypodium repens Aubl., Hist. Pl. Guiane 2: 962. 1775.

Figures: 35E, F

Habit/Habitat: Herb; epiphyte in forest on terra firme.

Material examined: Acrelandia, T.B. Croat 85921 (MO, NY); Rio Branco, C. A. Cid \& B.W. Nelson 2816 (NY), T.B. Croat 86111 (MO, NY); Rodrigues Alves, J. Prado et al. 1273 (SP, UFACPZ).

World Distribution: Mexico, Antilles, Mesoamerica, and tropical South America.

Characterized by slender (1.5-3 mm diam.), long-creeping rhizomes, very short (0.5-0.8 $\mathrm{mm}$ long) petioles, and undivided areoles containing only 2 excurrent veinlets. Greatly resembling Campyloneurum fuscosquamatum, differing only by pale-margined rhizome scales. More study needed

\section{Microgramma C. Presl, Tent. Pterid. 213. 1836.}

Characterized by long-creeping rhizomes with non-clathrate scales, simple and entire laminae, and sori in one row between the rachis and margin. Other characters are: plants epiphytic, rarely rupicolous; sterile and fertile leaves monomorphic or (more commonly) dimorphic with the fertile leaves longer and narrower than the sterile; laminae entire, ovate to elliptic or oblong; veins areolate, the areoles with included veinlets; sori round or rarely oblong, in a single row between the rachis and margin; paraphyses present, consisting of narrow scales; spores monolete, yellow.

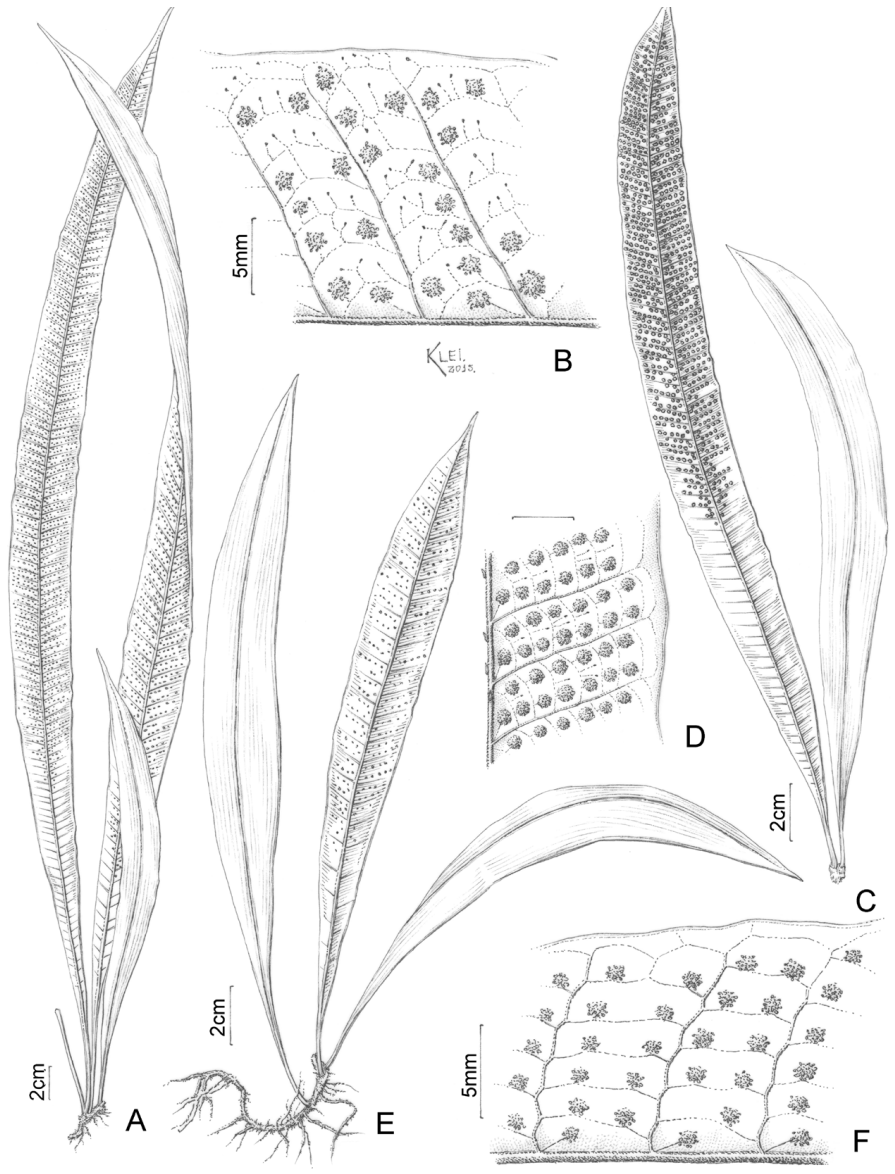

Figure 35. A-D. Campyloneurum phyllitidis. A. Habit. B. Fertile frond (A, B. Pardo et al. 94, NY). C. Habit. D. Sterile frond (C, D. Prado et al. 1377, SP). E, F. Campyloneurum repens (Prado et al. 1273, SP). E. Habit. F. Fertile frond. 
Neotropics, and ( 2 species) southern Africa and islands of the Indian Ocean; 30 species, 9 in Acre.

1. Rhizomes distincly flattened, more than $10 \mathrm{~mm}$ wide M. megalophylla

1. Rhizomes terete or nearly so, $1-4 \mathrm{~mm}$ wide

2. Rhizomes with tubers inhabited by ants M. bifrons

2. Rhizomes without tubers

3. Sterile and fertile leaves dimorphic or subdimorphic

4. Laminar tissue coriaceous, glabrous; leaves subdimorphic M. baldwinii

4. Laminar tissue chartaceous, scaly, the scales minute; leaves strongly dimorphic

5. Sori slightly protruding beyond the leaf margins

M. reptans

5. Sori within the leaf margins M. tecta var. nana

3. Sterile and fertile leaves monomorphic

6. Sori oblong M. persicariifolia

6. Sori round

7. Sori prominulous on the adaxial laminar surface; laminae coriaceous

M. percussa

7. Sori not prominulous on the adaxial laminar surface; laminae chartaceous

8. Laminae abaxially with small black dots

\section{M. dictyophylla}

8. Laminae abaxially without dots

M. thurnii

Microgramma baldwinii Brade, Arch. Jard. Bot. Rio de Janeiro 18: 30, tab. 1. 1965.

Figure: 36A

Habit/Habitat: Herb; epiphyte in forest on terra firme, near stream margins.

Material examined: Cruzeiro do Sul, J. Prado et al. 1353 (SP, UFACPZ), G.T. Prance et al. 12515 (MG, NY), N.A. Rosa 716 (NY); Mâncio Lima, M. Silveira et al. 1366 (NY); Rodrigues Alves, J. Prado et al. 1235 (UFACPZ), J. Prado et al. 1267 (SP, UFACPZ), J. Prado et al. 1282 (UFACPZ), J. Prado et al. 1368 (UFACPZ).

World Distribution: N South America to Bolivia.

Characterized by petioles lacking or nearly so, laminae glabrous, coriaceous, and obtuse, and sori embossed on the lamina adaxially. Rhizome scales easily fall off in dried specimens.

Microgramma bifrons (Hook.) Lellinger, Amer. Fern J. 67(2): 59. 1977. Polypodium bifrons Hook., Fil. Exot. tab. 52. 1859.

Figures: 36B-D

Habit/Habitat: Herb; canopy epiphyte, in open forest.

Material examined: Mâncio Lima, D.C. Daly et al. 8998 (NY, UFACPZ).

World Distribution: Mesoamerica and N South America to Bolivia.

Distinguished from all other species of Microgramma in Acre by ant-inhabited tubers on the rhizomes. The entrance hole for the ants is located on the ventral side of the tubers, facing the substrate. The plants grow roots into the chambers and absorb water and mineral nutriens from the organic matter left by the ants. The common name "potato fern" refers to the ant-inhabited tubers, which resemble a small potato. Microgramma bifrons has long been called Solanopteris bifrons (Hook.) Copel., but molecular phylogenetic studies have shown that Solanopteris nests in Microgramma (Schneider et al. 2004; Salino et al. 2008).

Microgramma dictyophylla (Kunze ex Mett.) de la Sota, Novon 17(1): 27-28. 2007. Polypodium dictyophyllum Kunze ex Mett., Abh. Senckenberg. Naturf. Ges. 2: 96. 1856.

Figures: 36E, F

Habit/Habitat: Herb; epiphyte, in forest on terra firme.

Material examined: Mâncio Lima, D.C. Daly et al. 8955 (NY, UFACPZ), P.J.M. Maas et al. 8932 (NY); Tarauacá, G.T. Prance et al. 7258 (MG, NY); Without locality, J. Jangoux et al. 85-094 (MG, NY); M. Silveira et al. 3976 (NY).

World Distribution: Mesoamerica and N South America to Bolivia.

Characterized by small black dots on the laminae abaxially, and by sori with many dark reddish paraphyses. The first series of areoles adjacent to the midrib lacks a free included vein. This species has long been called Microgramma fuscopunctata (Hook.) Vareschi.

Microgramma megalophylla (Desv.) de la Sota, Bol. Soc. Argent. Bot. 10: 158. 1963. Polypodium megalophyllum Desv., Mém. Soc. Linn. Paris 6: 227. 1827.

Figure: $36 \mathrm{G}$

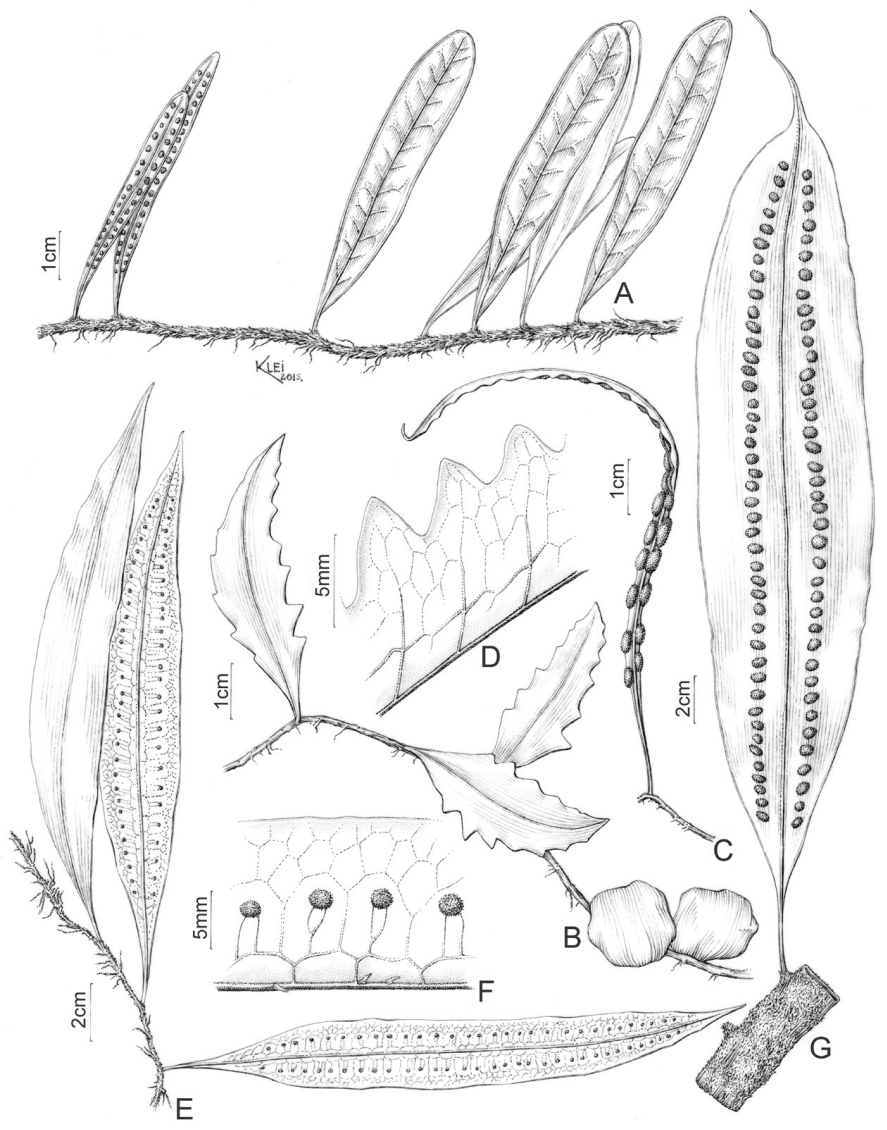

Figure 36. A. Microgramma baldwinii (Prado et al. 1267, SP). A. Habit. B, D. Microgramma bifrons (from Peru, Madre de Díos, Valenzoela et al. 4087, NY). B. Habit. C. Fertile frond. D. Venation. E, F. Microgramma dictyophylla (Silveira et al. 3976, NY). E. Habit. F. Veins and sori. G. Microgramma megalophylla (Prado et al. 1265, SP). G. Habit. 
Habit/Habitat: Herb; canopy epiphyte, in forest on terra firme.

Material examined: Cruzeiro do Sul, P.J.M. Maas et al. P12725 (MG, NY), J. Prado et al. 1196 (SP, UFACPZ), G.T. Prance et al. 12595 (MG, NY), J. Pruski et al. 3465 (NY); Mâncio Lima, M. Silveira et al. 1307 (NY); Rodrigues Alves, J. Prado et al. 1265 (SP, UFACPZ); Without locality, J. Jangoux et al. 85-015 (NY).

World Distribution: N South America to Bolivia.

Characterized by flattened, $1-3 \mathrm{~cm}$ wide rhizomes covered by whitish scales. It grows only in the canopy, not on lower portions of trunks. The species name "megalophylla" refers to the large leaves, which are typically $20-40 \mathrm{~cm}$ long.

Microgramma percussa (Cav.) de la Sota, Physis (Buenos Aires) 44(106C): 28. 1986. Polypodium percussum Cav., Descr. Pl. 243-244. 1802.

Figures: 37A, B

Habit/Habitat: Herb; epiphyte, terra firme forest on gently undulating terrain, undisturbed but canopy open.

Material examined: Bujari, M. de Pardo et al. 92 (NY, UFACPZ); Cruzeiro do Sul, D.C. Daly et al. 11657 (NY), D.C. Daly et al. 11714 (NY), P.J.M. Maas et al. P13133B (NY), J. Prado et al. 1346 (UFACPZ), J. Prado et al. 1375 (UFACPZ); Feijó, P. Delprete et al. 8310 (NY), P. Delprete et al. 8488 (NY); Manoel Urbano, D.C. Daly et al. 11218 (NY), D.C. Daly et al. 11420 (NY); Marechal Thaumaturgo, D.C. Daly et al. 10297 (NY), L.G. Lohmann et al. 458 (NY); Sena Madureira, M. Silveira et al. 616 (NY, UFACPZ); Tarauacá, C. Ehringhaus et al. 382 (NY), G.T. Prance et al. 7380 (NY).

World Distribution: S Mexico, Mesoamerica, and tropical South America.

Characterized by sori embossed on the adaxial laminar surface, and by the often long-attenuate laminar apices. The abaxial surface of the laminae is sparsely covered by peltate centrally darkened scales. The sori are distinctive: their yellow sporangia are embedded in a reddish mass of paraphyses.

Microgramma persicariifolia (Schrad.) C. Presl, Tent. Pterid. 214. 1836. Polypodium persicariifolium Schrad., Gött. Gel. Anz. 1824: 867. 1824.

Figures: 37C, D

Habit/Habitat: Herb; hemiepiphyte in várzea forest.

Material examined: Bujari, D.C. Daly et al. 8497 (NY, UFACPZ); Cruzeiro do Sul, D.C. Daly et al. 7300 (NY, UFACPZ); Mâncio Lima, G.T. Prance et al. 12061 (NY); Santa Rosa, D.C. Daly et al. 10103 (NY), D.C. Daly et al. 11340 (NY); Sena Madureira, A.R.S. Oliveira et al. 622 (NY), M. de Pardo et al. 148 (NY, UFACPZ); Xapuri, L.G. Lohmann et al. 600 (NY); Without locality, D.G. da Silva et al. 57 (NY).

World Distribution: Costa Rica, Panama, and tropical South America.

The only species of Microgramma with oblong sori. This and the glabrous laminae are the two good morphological characters to identify this species. The species is a hemiepiphyte, starting around the bases of trunks and sending long roots into the soil from the proximal part of the climbing rhizome.

Microgramma reptans (Cav.) A.R. Sm., Proc. Calif. Acad. Sci., ser. 4, 40(8): 230. 1975. Acrostichum reptans Cav., Anales Hist. Nat. 1: 104. 1799.

Figures: 37E, F

Habit/Habitat: Herb; epiphyte in forest on terra firme.

Material examined: Bujari, M. de Pardo et al. 100 (NY); Cruzeiro do Sul, D.C. Daly et al. 11813 (NY); Manoel Urbano, D.C. Daly et al. 11252 (NY); Marechal Thaumaturgo, D.C. Daly et al. 10571 (NY); Porto Acre, A.R.S. Oliveira et al. 744 (NY); Porto Valter, P.J.M. Maas et al. 13057 (NY); Sena Madureira, D.C. Daly et al. 8081 (NY, UFACPZ).

World Distribution: Mexico, Cuba, Mesoamerica, and tropical South America.
Distinct from other species of Microgramma in Acre by sterile and fertile leaves strongly dimorphic, the sterile ones elliptic or ovate-oblong, $2-6 \mathrm{~cm}$ long, and the fertile ones oblong to linear with the sori extending slightly beyond the leaf margins.

Microgramma tecta (Kaulf.) Alston var. nana (Liebm.) Mickel \& Beitel, Mem. New York Bot. Gard. 46: 251, f. 55R-T. 1988. .Acrostichum nanum Liebm., Kongel. Danske Vidensk. Selsk. Naturvidensk. Math. Afh. 1: 171. 1849.

Figures: $37 \mathrm{G}, \mathrm{H}$

Habit/Habitat: Herb; epiphyte, often in the canopy and especially on small diameter branches, in forest near stream margins.

Material examined: Cruzeiro do Sul, J. Prado et al. 1296 (SP, UFACPZ), J. Prado et al. 1372 (SP, UFACPZ); Rodrigues Alves, J. Prado et al. 1274 (SP, UFACPZ).

World Distribution: Guianas and Brazil.

Characterized by strongly dimorphic sterile and fertile leaves, the sterile ones roundish or ovate, ca. 1-2 cm long, and sori not extending beyond the leaf margins.

Microgramma thurnii (Baker) R.M. Tryon \& Stolze, Fieldiana, Bot., n.s. 32: 156. 1993. Polypodium thurnii Baker, Ann. Bot. (Oxford) 5: 476. 1891.

Figures: 38A, B

Habit/Habitat: Herb; epiphyte in forest on terra firme.

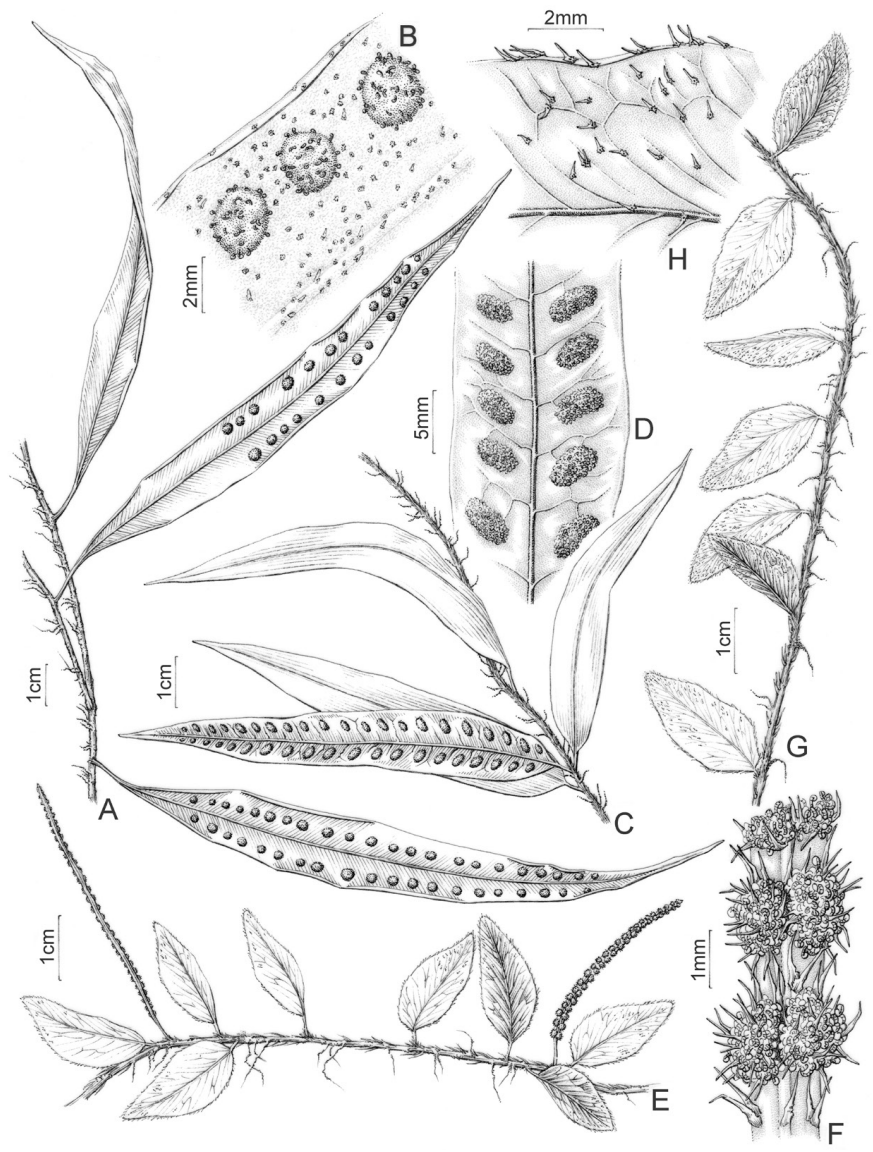

Figure 37. A, B. Microgramma percussa (Daly et al. 11420, NY). A. Habit. B. Fertile frond. C, D. Microgramma persicariifolia (Prance et al. 12061, NY) C. Habit. D. Fertile frond. E, F. Microgramma reptans (Daly et al. 10571, NY). E. Habit. F. Fertile frond. G, H. Microgramma tecta var. nana (Prado et al. 1372 SP). G. Habit. H. Sterile frond. 


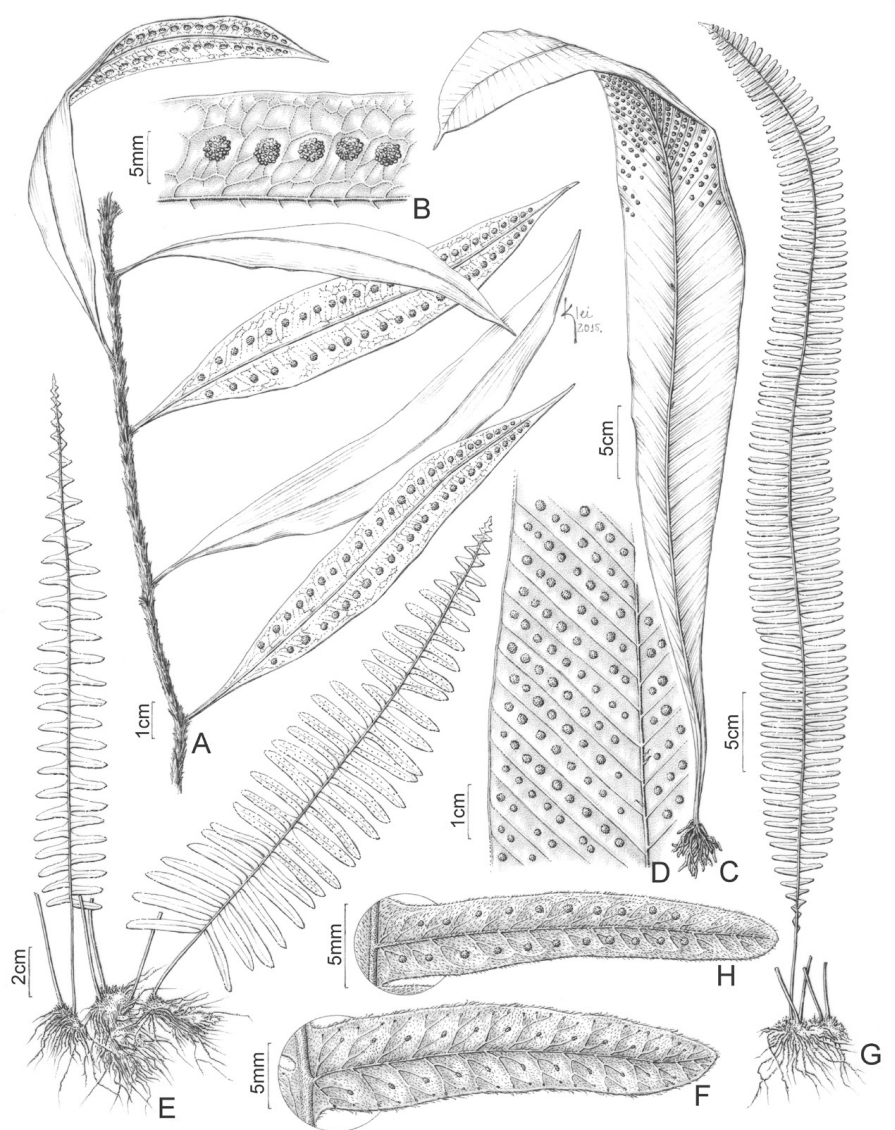

Figure 38. A, B. Microgramma thurnii (Prado et al. 1299, SP). A. Habit. B. Fertile frond. C, D. Niphidium crassifolium (Prado et al. 1263, SP). C. Habit. D. Fertile frond. E, F. Pecluma hygrometrica (Daly et al. 10988, NY). E. Habit. F. Sterile frond. G, H. Pecluma pectinata (Prance et al. 2784, NY). G. Habit. H. Fertile frond.

Material examined: Cruzeiro do Sul, P. Delprete et al. 8092 (NY), J. Prado et al. 1299 (SP, UFACPZ), J. Prado et al. 1328 (SP, UFACPZ), J. Prado et al. 1357 (SP, UFACPZ), J. Prado et al. 1373 (SP, UFACPZ), J. Prado et al. 1383 (SP, UFACPZ); Mâncio Lima, J. Prado et al. 1218 (SP, UFACPZ); Porto Valter, D.C. Daly et al. 11789 (NY), P.J.M. Maas et al. $13133 A$ (NY); Rodrigues Alves, J. Prado et al. 1250 (UFACPZ); Without locality, J. Jangoux et al. 85-035 (NY).

World Distribution: N South America to Bolivia.

Recognized in the field by the shiny leaves glabrous on both surfaces.

Niphidium J. Sm., Hist. Fil. 99. 1875.

Characterized by the simple, entire, coriaceous laminae with one row of large sori between the main lateral veins. Another character includes finely reticulate venation between the main lateral veins (this often hard to see because of the thick laminae).

Neotropical; 10 species, 1 in Acre.

Niphidium crassifolium (L.) Lellinger, Amer. Fern J. 62(4): 106. 1972. Polypodium crassifolium L., Sp. P1. 2: 1083. 1753.

Figures: 38C, D

Habit/Habitat: Herb; epiphyte in forest on terra firme.

Material examined: Brasiléia, D.C. Daly et al. 11889 (NY); Marechal Thaumaturgo, D.C. Daly et al. 10246 (NY); Rodrigues Alves, J. Prado et al. 1263 (SP, UFACPZ), J. Prado et al. 1283 (SP, UFACPZ).
World Distribution: Mexico, Antilles, Mesoamerica, and tropical South America.

An epiphyte recognized by the central cells of the rhizome scales elongate, $3-5 \times$ as long as broad. The veins between the main lateral ones are finely reticulate, and the vein tips on the adaxial surface are often modified as whitish hydathodes.

Pecluma M.G. Price, Amer. Fern J. 73(4): 109. 1983.

Characterized by rhizome scales pubescent with brown hairs at least at the point of attachment, laminae with 30 or more segments (pinnae) perpendicular or nearly so to the rachis (laminae pectinate), rachises puberulent adaxially, typically free veins, and sporangial capsules often with a setula. All species have short-creeping, unbranched rhizomes with non-clathrate concolorous scales. The segments are adnate (never stalked) to the rachises and entire or nearly so, never serrate; sori round; paraphyses present; sporangia glabrous or setulose. Pecluma was segregated from Polypodium by Price (1983).

Neotropical; ca. 40 species, 4 in Acre.

1. Rachis scales conspicuous, narrowly deltate, ciliate ......P. plumula

1. Rachis scales inconspicuous, filiform, entire

2. Proximal segments not reduced or slightly reduced toward the base of the lamina P. hygrometrica

2. Proximal segments gradually reduced toward the base of the lamina 3. Laminar tissue evenly puberulent on both surfaces .... P. pectinata

3. Laminar tissue glabrous adaxially, sparsely puberulent abaxially, hairs more evident near the sori ........................ P. pilosa

Pecluma hygrometrica (Splitg.) M.G. Price, Amer. Fern J. 73(4): 115. 1983. Polypodium hygrometricum Splitg., Tijdschr. Nat. Geschied. 7: 409.1840.

Figures: 38E, F

Habit/Habitat: Herb; epiphyte in open forest on terra firme with palms, undulating terrain.

Material examined: Cruzeiro do Sul, D.C. Daly et al. 7488 (NY); Santa Rosa, D.C. Daly et al. 10176 (NY), D.C. Daly et al. 10988 (NY).

World Distribution: S Mexico, Mesoamerica, and N South America to Bolivia.

Characterized by narrowly deltate laminae that are truncate basally or with a few proximal segments slightly reduced, reddish brown rachises with brown hairs and scattered filiform scales, laminar tissue evenly puberulent on both surfaces, and sporangial capsules minutely setulose.

Pecluma pectinata (L.) M.G. Price, Amer. Fern J. 73(4): 115. 1983. Polypodium pectinatum L., Sp. Pl. 2: 1085-1086. 1753.

Figures: $38 \mathrm{G}, \mathrm{H}$

Habit/Habitat: Herb; epiphyte in várzea forest.

Material examined: Bujari, M. de Pardo et al. 95 (NY); Cruzeiro do Sul, G.T. Prance et al. 2784 (NY).

World Distribution: Antilles, Mesoamerica, and tropical South America.

Characterized by laminae abruptly reduced toward the base, vestigial proximal segments, rachises reddish brown with reddish brown hairs, scales absent or rare and filiform, laminar tissue evenly puberulent on both surfaces, and sporangial capsules with one setula.

Pecluma pilosa (A.M. Evans) M. Kessler \& A.R. Sm., Candollea 60(1): 281. 2005. Polypodium ptilodon Kunze var. pilosum A.M. Evans, Ann. Missouri Bot. Gard. 55(3): 259, fig. 20. 1968[1969]. 
Figures: 39A, B

Habit/Habitat: Herb; epiphyte in forest on terra firme.

Material examined: Mâncio Lima, D.C. Daly et al. 8945 (NY, UFACPZ), G.T. Prance et al. 12282 (NY).

World Distribution: N South America to Bolivia.

Characterized by laminae gradually reduced toward the base, the proximal segments auriculate, rachises brown with hairs of two types: acicular hairs and "Ctenitis hairs" (minute and branched), laminar tissue sparsely puberulent abaxially, the hairs are more evident near the sori, adaxially glabrous, "Ctenitis hairs" present on both surfaces of the veins, and sporangial capsules setulose.

Pecluma plumula (Humb. \& Bonpl. ex Willd.) M.G. Price, Amer. Fern J. 73(4): 115. 1983. Polypodium plumula Humb. \& Bonpl. ex Willd., Sp. Pl., ed. 4 [Willdenow] 5: 178. 1810.

Figures: 39C, D

Habit/Habitat: Herb; epiphyte, in riverside vegetation.

Material examined: Manoel Urbano, D.C. Daly et al. 11546 (NY); Marechal Thaumaturgo, D.C. Daly et al. 10530 (NY); Quixadá, E. Forero et al. 6347 (NY); Rio Branco, D.C. Daly et al. 6923 (NY); C.S. Pessôa et al. 227 (NY); Santa Rosa, D.C. Daly et al. 11057 (NY); Sena Madureira, D.C. Daly et al. 7907 (NY); Tarauacá, G.T. Prance et al. 7248 (NY); G.T. Prance et al. 7385 (MG, NY).

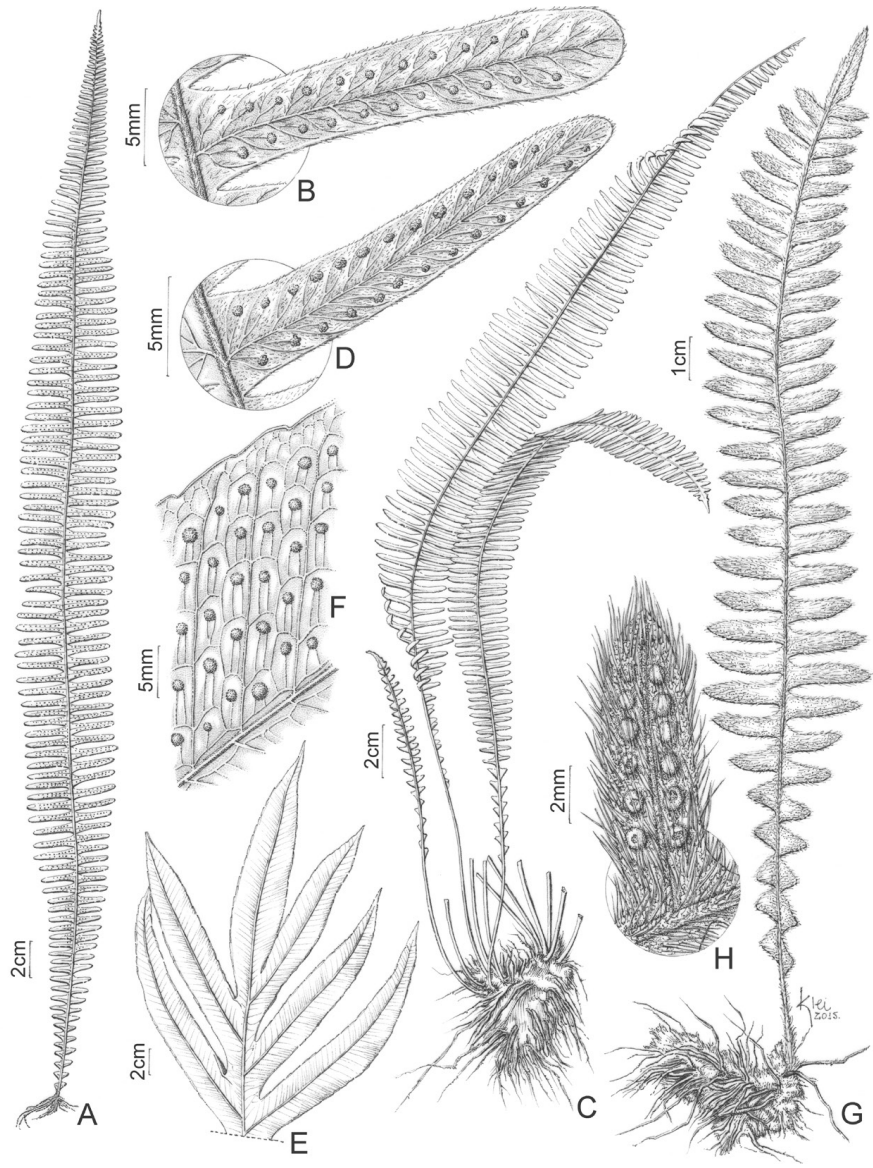

Figure 39. A, B. Pecluma pilosa (Prance et al. 12282, NY). A. Habit. B. Fertile frond. C, D. Pecluma plumula (Pessôa et al. 227, NY). C. Habit. D. Fertile frond E, F. Phlebodium decumanum (Maas et al. P13299, NY). E. Part of a frond F. Fertile frond. G, H. Pleopeltis bombycina (Prado et al. 1234, SP). G. Habit. H. Fertile frond.
World Distribution: Florida, Mexico, Antilles, Mesoamerica, and tropical South America.

Characterized by laminae gradually reduced toward the base and proximal segments auriculate, rachises blackish with hairs and conspicuous scales, the scales are narrowly deltate and ciliate at margins, laminar tissue sparsely puberulent on both surfaces, and sporangial capsules setulose.

Phlebodium (R. Br.) J. Sm., J. Bot. (Hooker) 4: 58. 1841. Polypodium sect. Phlebodium R. Br., Pl. Jav. Rar. 4. 1838.

Characterized by densely orangish-scaly rhizomes; laminae pinnatisect with wide sinuses and a conform terminal segment; areolate veins, whitish hydathodes, and sori typically supplied by two viens. The laminae are often glaucous beneath and sometimes have a bluish cast.

Neotropical; 4 species, 1 in Acre.

Phlebodium decumanum (Willd.) J. Sm., J. Bot. (Hooker) 4: 59. 1841 Polypodium decumanum Willd., Sp. Pl., ed. 4 [Willdenow] 5: 170. 1810.

Figures: 1G, 39E, F

Habit/Habitat: Herb; epiphyte in forest on terra firme.

Material examined: Manoel Urbano, D.C. Daly et al. 11209 (NY); Porto Valter, P.J.M. Maas et al. P13299 (NY); Rio Branco, C.A. Cid \& A. Souza 2986 (NY), D.C. Daly et al. 6871 (NY, UFACPZ); Santa Rosa, D.C. Daly et al. 10119 (NY), D.C. Daly et al. 11272 (NY); Sena Madureira, D.C. Daly et al. 8096 (NY, UFACPZ); Tarauacá, P. Delprete et al. 8257 (NY); Xapuri, D.C. Daly et al. 8414 (NY).

World Distribution: S Florida, Antilles, Mesoamerica, and tropical and subtropical South America.

Distinct from its congeners by 7 rows of sori between the costa and margins of the lamina.

Pleopeltis Humb. \& Bonpl. ex Willd., Sp. Pl. 5: 211. 1810.

Characterized by rhizome scales clathrate (at least medially; the cell luminae sometimes obscured), peltate, with or without rhizoids; sterile and fertile leaves monomorphic or dimorphic; petioles terete, articulate to short phyllopodia; laminae simple to 1-pinnate basally, rarely more divided, scaly, the scales circular to ovate or lanceolate, peltately attached, these clathrate at least centrally; veins areolate, not evident; sori borne at the juncture of several veinlets, round or rarely elongate or linear, in one row between the rachis (or costa) and margin, young sori typically protected by overlapping, circular, peltate scales.

Predominantly Neotropical, also southern Africa; 90 species; 4 in Acre.

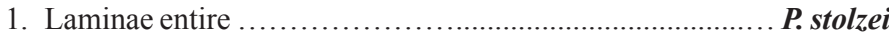

1. Laminae divided

2. Laminae pseudodichotomously divided P. desvauxi

2. Laminae pinnatisect

3. Proximal segments reduced to auricles P. bombycina

3. Proximal segments not reduced .... P. polypodioides var. burchellii

Pleopeltis bombycina (Maxon) A.R. Sm., Candollea 60(1): 281. 2005. Polypodium bombycinum Maxon, Contr. U.S. Natl. Herb. 17(7): 592. 1916.

Figures: 39G, H

Habit/Habitat: Herb; epiphyte in forest on terra firme.

Material examined: Cruzeiro do Sul, D.C. Daly et al. 11656 (NY), J. Prado et al. 1392 (SP, UFACPZ), G.T. Prance et al. 11894 (NY), G.T. Prance et al. 11927 (NY), G.T. Prance et al. 12529 (NY); Mâncio Lima, G.T. Prance et al. 12040 (MG, NY); Rio Branco, D.C. Daly et al. 6868 (NY), E. Forero et al. 6346 (NY); Rodrigues Alves, J. Prado et al. 1234 (SP, UFACPZ). 
World Distribution: Mesoamerica and N South America to Bolivia.

Distinguished by pinnatisect laminae gradually reduced toward the base with the lowermost segments auriculate, and both surfaces scaly, the scales orbicular and ciliate at base and with a very long filiform apex with denticulate margins, reddish orange or reddish brown.

Pleopeltis desvauxii (Klotzsch) Salino, Amer. Fern J. 99(2): 107. 2009. Taenitis desvauxii Klotzsch, Linnaea 20: 431. 1847.

Figures: 1E, 40D, E

Habit/Habitat: Herb; epiphyte in forest on terra firme.

Material examined: Bujari, D.C. Daly et al. 9466 (NY); Cruzeiro do Sul, J. Prado et al. 1213 (UFACPZ), J. Prado et al. 1393 (SP, UFACPZ); Mâncio Lima, G.T. Prance et al. 12247 (NY), G.T. Prance et al. 12607 (NY); Rodrigues Alves, J. Prado et al. 1239 (SP, UFACPZ), J. Prado et al. 1251 (UFACPZ); Without locality, J. Jangoux et al. 85-113 (NY).

World Distribution: Lesser Antilles and tropical South America.

The only species of Pleopeltis in Acre with laminae subdichotomously divided. The laminar segments are narrow (5-8 $\mathrm{mm}$ wide).

Pleopeltis polypodioides (L.) E.G. Andrews \& Windham var. burchellii (Baker) A.R. Sm., Candollea 60(1): 281. 2005. Polypodium incanum var. burchelli Baker, Fl. Bras. 1(2): 526. 1870.

Figures: $40 \mathrm{~A}-\mathrm{C}$

Habit/Habitat: Herb; epiphyte in forest on terra firme.

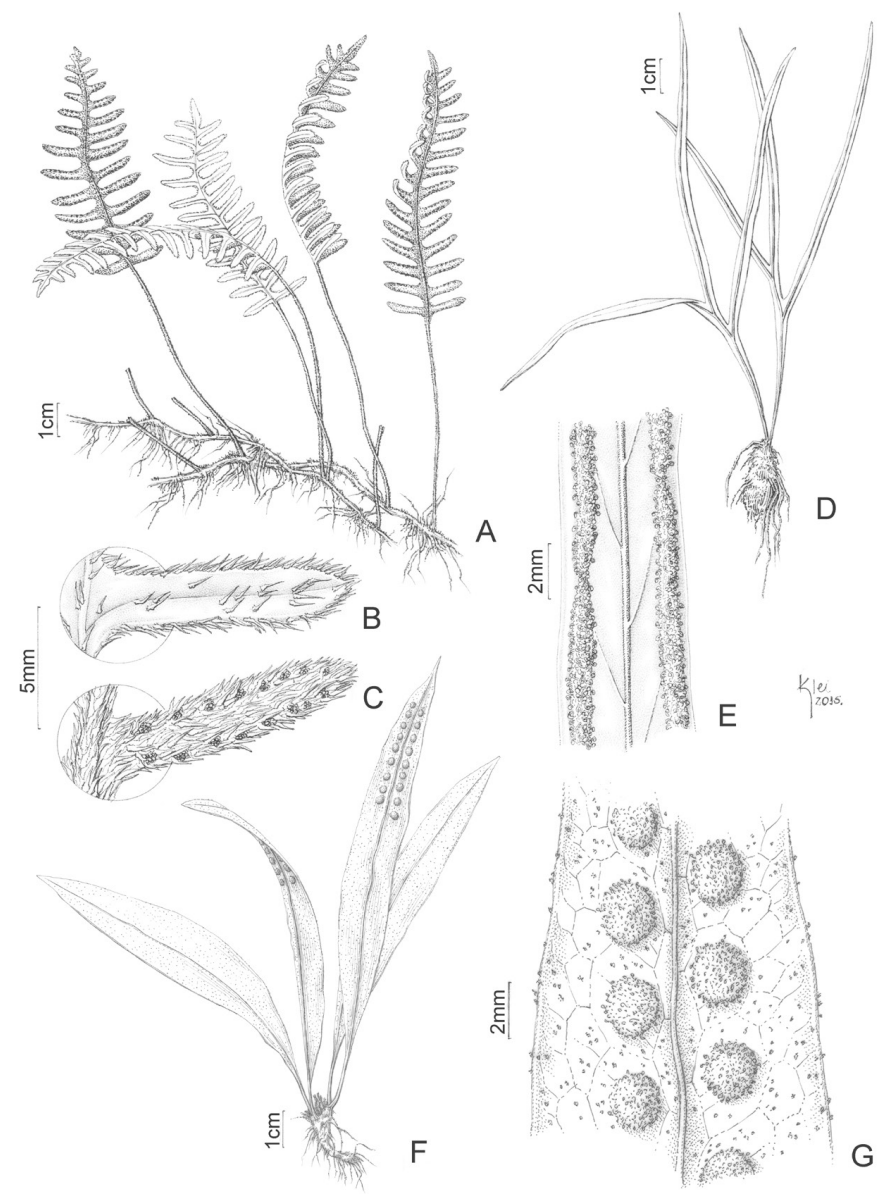

Figure 40. A-C. Pleopeltis polypodioides var. burchellii (Daly et al. 11562, NY). A. Habit. B. Fertile frond. C. Fertile frond. D, E. Pleopeltis desvauxii. D. Habit (Prado et al. 1393, SP). E. Fertile frond (Prance et al. 12607, NY). F, G. Pleopeltis stolzei (Almeida \& Salino 2629, BHCB). F. Habit. G. Fertile frond.
Material examined: Assis Brasil, D.C. Daly et al. 9813 (NY, UFACPZ); Manoel Urbano, D.C. Daly et al. 9081 (NY), D.C. Daly et al. 11219 (NY), D.C. Daly et al. 11562 (NY); Rio Branco, C.A. Cid 2893 (MG, NY), D.C. Daly et al. 9516 (NY, UFACPZ), D.C. Daly et al. 9526 (NY, UFACPZ), B. Nelson 737 (MG, NY); Sena Madureira, D.C. Daly et al. 7908 (NY, UFACPZ).

World Distribution: Mesoamerica, Antilles, and tropical South America.

Characterized by long-creeping rhizomes, bicolorous rhizome scales, pinnatisect, deltate or oblong leaves, proximal segments not reduced, and laminae abaxially densely scaly, the scales ovate, orangish to brown, clathrate in the center, with base ciliate, margins whitish, and with a very long filiform apex, adaxially sparsely scaly, the scales round at base, light brown, base ciliate, and long filiform apex. The leaves of this species curl when dry, exposing the abaxial surface outward. Upon rehydration they expand rapidly and resume photosynthesis with harmful effects from the drying.

Pleopeltis stolzei A.R. Sm., Candollea 60(1): 282. 2005.

Figures: 40F, G

Habit/Habitat: Herb; epiphyte in forest on terra firme.

Material examined: Mâncio Lima, T.E. Almeida \& A. Salino 2629 (BHCB).

World Distribution: Peru, Bolivia, and Brazil.

Characterized by both surfaces of the laminae sparsely scaly, the scales of two types. The first is round with laciniate margins; the second is ovate-lanceolate with denticulate margins. Both scales are orangish or light brown and clathrate in the center.

Compared to other species of Pleopeltis, this one has restricted geographic distribution, being known only from Bolivia and Brazil. Its occurrence in Brazil was recently reported by Almeida \& Salino (2015).

Serpocaulon A.R. Sm, Taxon 55(4): 924-927, fig. 3-4. 2006.

Characterized by rhizomes long-creeping with phyllopodia $(0.5-) 5-20 \times$ the rhizome width apart, sometimes glaucous; scales peltate, clathrate; petioles grooved adaxially or terete (in $S$. aff. latipes (Langsd. \& Fisch.) A.R. Sm.); laminae pinnatifid to pinnate, rarely simple (S. levigatum (Cav.) A.R. Sm.) or shallowly pinnatifid, monomorphic; veins regularly anastomosing, the areoles with a single, free, included vein (goniophlebioid veins); sori round or nearly so, in 1-10 rows between costae and margins, terminal on a free included vein; paraphyses absent or present and short, 2- or 3-celled, glandular, not easily seen; sporangia glabrous. Most species are epiphytes.

Serpocaulon was segregated from Polypodium s.l. by Smith et al. (2006) and has been adopted in all recent papers.

Neotropical; ca. 40 species, 3 in Acre.

1. Leaves pinnate-pinnatisect S. aff. latipes

1. Leaves 1-pinnate

2. Pinnae elliptic; rhizome scales spreading S. caceresii

2. Pinnae oblong; rhizome scales appressed S. triseriale

Serpocaulon caceresii (Sodiro) A.R. Sm., Taxon 55(4): 928, fig. 3A. 2006. Polypodium caceresii Sodiro, Crypt. Vasc. Quit. 360. 1893.

Figures: 41A, B

Habit/Habitat: Herb; epiphyte in forest on terra firme.

Material examined: Cruzeiro do Sul, J. Prado et al. 1210 (SP, UFACPZ); Mâncio Lima, G.T. Prance et al. 12141 (NY); Rodrigues Alves, J. Prado et al. 1253 (SP, UFACPZ); Santa Rosa, D.C. Daly et al. 10169 (NY); Without locality, J. Jangoux et al. 85-037 (NY).

World Distribution: N South America to Bolivia. 
Characterized by leaves 1-pinnate, pinnae elliptic, sessile or slightly adnate, and rhizome scales spreading, distinctly clathrate throughout, iridescent, and dark brown.

Serpocaulon aff. latipes (Langsd. \& Fisch.) A.R. Sm., Taxon 55(4): 928. 2006. Polypodium latipes Langsd. \& Fisch., Pl. Voy. Russes Monde 1: 10, pl. 10. 1810 .

Habit/Habitat: Herb; epiphyte, in open forest.

Material examined: Mâncio Lima, M. Silveira et al. 1244 (NY).

World Distribution: S Mexico, Antilles, Mesoamerica, and N South America and maybe in Bolivia.

Characterized by long-creeping, non-glaucous rhizomes with appressed, sparse, bicolorous (dark-clathrate centrally with narrow pale margins) scales, pinnatisect leaves, pinnae bases adnate and expanded equally on both sides (surcurrent and decurrent), rachises glabrous on both surfaces, and 2 rows of areoles between costae and pinna margins.

Serpocaulon triseriale (Sw.) A.R. Sm., Taxon 55(4): 929, figs. 3F, 4L-O. 2006. Polypodium triseriale Sw., J. Bot. (Schrader) 2: 26. 1800[1801].

Figures: 41C, D

Habit/Habitat: Herb; epiphyte, in open forest.

Material examined: Mâncio Lima, D.C. Daly et al. 8944 (NY, UFACPZ).

World Distribution: S Mexico, Antilles, Mesoamerica, and N South America to Bolivia.

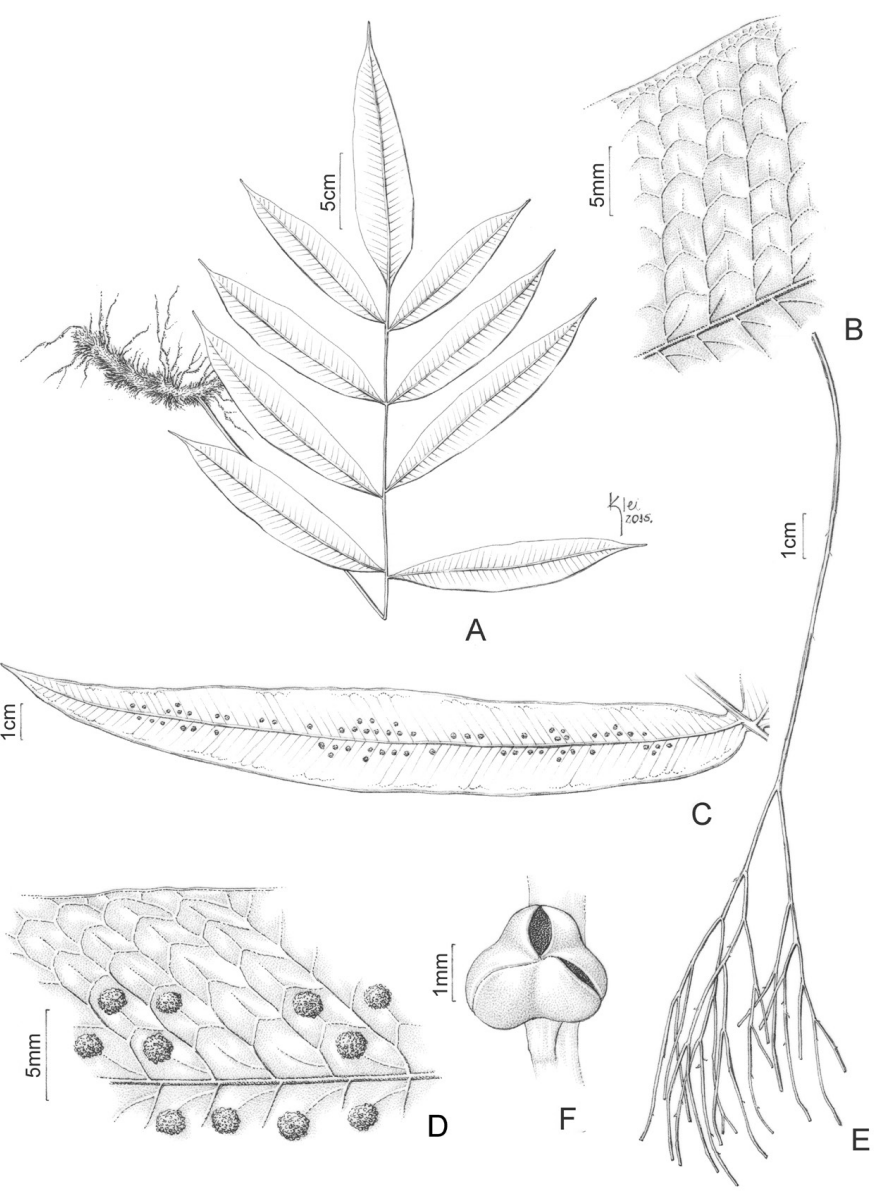

Figure 41. A, B. Serpocaulon caceresii (Prado et al. 1253, SP). A. Habit. B. Sterile frond. C, D. Serpocaulon triseriale (Daly et al. 8944, NY). C. Pinna. D. Fertile frond. E, F. Psilotum nudum (Nelson 614, NY). E. Habit. F. Synangium.
Characterized by 1-pinnate leaves, lanceolate-oblong pinnae, with at least the distal ones adnate to the rachis), and rhizome scales appressed, slightly iridescent, and brown. The sori are often raised (embossed) on the adaxial surface of the laminae.

\section{PSILOTACEAE}

Characterized by lack of roots, 2- or 3-locular synangia born on the adaxial surface of bifid sporophylls.

Pantropical, with extensions into the temperate zones; 2 genera. In Acre, 1 genus, 1 species.

Psilotum Sw., J. Bot. (Schrader) 1800(2): 8, 109. 1801.

Characterized by roots absent, green isodichotomous stems, small sterile leaves (in Psilotum, 1-2 mm long), these scale-like, without veins, sporangia 2- or 3-locular, sessile in the fork of bifid leaves. The distance between successive dichotomies decreases distally along the shoots. The synangia are born along the distal branches only. When mature, the sporangia are yellow and contrast sharply in color with the green stems.

Pantropical; 2 species, 1 in Acre.

Psilotum nudum (L.) P. Beauv., Prodr. Aétheogam. 106, 112. 1805 Lycopodium nudum L., Sp. Pl. 2: 1100-1101. 1753.

Figures: 41E, F

Habit/Habitat: Herb; pendant epiphyte, in open forest, growing on the old persistant leaf bases of palms where humus has collected.

Material examined: Brasiléia, D.C. Daly et al. 9693 (NY); Rio Branco, D.C. Daly et al. 6669 (NY, UFACPZ); Sena Madureira, B. Nelson 614 (NY), G.T. Prance et al. 7956 (NY); Xapuri, D.C. Daly et al. 8430 (NY, UFACPZ), C. Figueiredo 211 (NY, UFACPZ); Without locality, J.M. Pires et al. 10058 (NY).

World Distribution: subcosmopolitan.

\section{PTERIDACEAE}

This family never has true indusia. When present, the indusia are formed by the reflexed margins of the laminae (false indusia). In some members of the family, the sporangia spread along the veins. The petiole bundles are diverse, varying from single and circular in cross section to 2 , or omega-shaped.

Cosmopolitan; 53 genera, ca. 1,211 species. In Acre, 8 genera, 37 species (largest family in the state).

1. Sterile and fertile laminae usually simple, in one species furcate at lamina tip (vittarioid ferns)

2. Laminae furcate, leaves $1-4 \mathrm{~cm}$ long; veins free ...... Hecistopteris

2. Laminae entire, leaves (5)10-100 cm long; veins areolate, at least with a marginal commissural vein

3. Laminae with 1 row of areoles between midribs and laminar margins; paraphyses present

Vittaria

3. Laminae with 2 or more rows of areoles between midrib and laminar margin; paraphyses present or absent

4. Sori in 2 lines on both sides of midrib; spores monolete ....

Ananthacorus

4. Sori in (2)3 or 4 lines; spores monolete or trilete

Polytaenium

1. Laminae (at least the fertile ones) pedate, pinnate, or more divided 
5. Indusia with veins, bearing sporangia directly on the underside of its reflexed tissue

Adiantum

5. Indusia absent, or if present, lacking veins and not bearing sporangia (these located on the laminar surfaces)

6. Indusia present; sporangia marginal Pteris

6. Indusia absent (sometimes pinna margins recurved); sporangia borne along the veins between the segment midrib and margin

7. Laminae simple to 1-pinnate, with acicular hairs on both surfaces, without farina abaxially

Hemionitis

7. Laminae 1-pinnate or 1-pinnate-pinnatifid or more divided, lacking acicular hairs on both surfaces, with whitish or yellowish farina abaxially

Pityrogramma

\section{Adiantum L., Sp. Pl. 2: 1094. 1753.}

Characterized by terete, blackish to castaneous petioles, rachises, and costae, and sporangia borne on the false indusium (i.e., not on the laminar surface below it). Also characterized by rhizomes short- to long-creeping, horizontal rhizomes, or these sometimes compact and suberect; scales borne at rhizome apices and petiole bases; laminae monomorphic, pinnate (rarely undivided) to 5-pinnate, sometimes pedate; veins free or rarely anastomosing without included free veinlets; linear epidermal idioblasts (false veins) present or not between the true

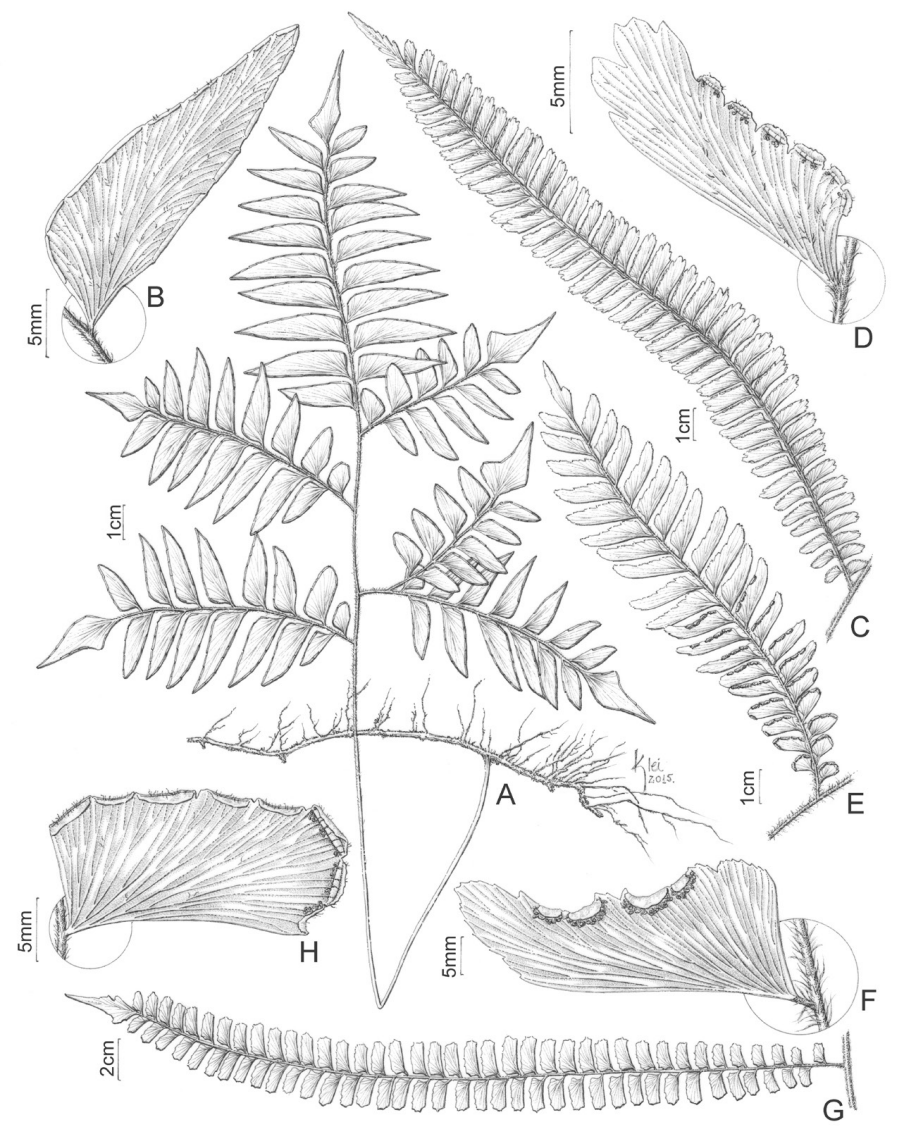

Figure 42.A, B. Adiantum argutum (Daly et al. 7990, NY). A. Habit. B. Fertile pinnule. C, D. Adiantum cajennense (Prado et al. 1293, SP). C. Fertile pinna. D. Fertile pinnule. E, F. Adiantum decoratum (Daly et al. 11365, NY). E. Fertile pinna. F. Fertile pinnule. G, H. Adiantum diogoanum (Daly et al. 9385, NY). G. Fertile pinna. H. Fertile pinnule. veins; sori formed on the recurved laminar margins (false indusia), on the veins, paraphyses absent.

Adiantum is sister to the vittarioid ferns (Schuettpelz et al. 2007, Pryer et al. 2016). These two lineages occupy different habitats. Adiantum is generally terrestrial, whereas the vittarioids are epiphytic.

Subcosmopolitan; ca. 225 species (ca. 110 of them Neotropical), 21 in Acre.

1. Laminae 1-pinnate (rarely 2-pinnate at bases)

2. Rachises glabrous

3. Leaves up to $70 \mathrm{~cm}$ long; rhizomes stout (5-10 $\mathrm{mm}$ diam.), short-creeping

A. platyphyllum

3. Leaves up to $25 \mathrm{~cm}$ long; rhizomes slender (1-3 mm diam.), long-creeping A. nudum

2. Rachises scaly and/or hairy

4. Rachises with scales and hairs

5. Pinnae or pinnules glabrous on both surfaces; idioblasts easily visible on adaxial laminar surfaces, mostly parallel between veins, not visible abaxially; indusia linear-arcuate

A. petiolatum

5. Pinnae or pinnules scaly on both surfaces; idioblasts visible on both laminar surfaces; indusia oblong A. obliquum

4. Rachises with only scales

6. Laminae hairy on both surfaces . A. scalare

6. Laminae scaly on both surfaces

7. Veins free; rhizomes long-creeping, non-nodose A. poeppigianum

7. Veins anastomosing or irregularly anastomosing; rhizomes short-creeping, nodose

8. Pinnae or pinnules $6-9 \times$ longer than wide, $3-5(-6)$ pairs, bases \pm equal-sided, rounded to slightly cuneate on both sides; veins anastomosing

A. dolosum

8. Pinnae or pinnules $(2-) 3-5(-7) \times$ longer than wide, 10-13 pairs, bases unequal-sided, rounded on acroscopic sides and cuneate on basiscopic sides; veins mostly free but with some irregular anastomoses

A. lucidum

1. Laminae 2-pinnate or more divided

9. Laminae 3- to 5-pinnate A. pectinatum

9. Laminae 2-pinnate

10. Rachises puberulent adaxially ...

A. tomentosum

10. Rachises scaly and/or hairy (but long-pubescent) adaxially

11. Rachises scaly and hairy

A. latifolium

11. Rachises scaly only

12. Rachises with one kind of scale (lanceolate to narrowly lanceolate with pectinate base) abaxially

13. Pinnae $2-4$ pairs; pinnules hairy abaxially 
14. Distal pinnules approximately half the size of largest pinnules; indusia glabrous A. humile

14. Distal pinnules less than half the size of largest pinnules; indusia hairy A. terminatum

13. Pinnae $3-10$ pairs; pinnules scaly abaxially

15. Pinnules $2 \times$ longer than wide A. multisorum

15. Pinnules $3-5 \times$ longer than wide

16. Pinnules $30-45$ pairs per pinna, sterile margins copiously denticulate-serrate; indusia scaly

A. cajennense

16. Pinnules $16-25$ pairs per pinna, sterile margins irregularly serrate; indusia hairy ..... A. diogoanum

12. Rachises with two kinds of scales (either hairlike and lanceolate, or arachnoid and lanceolate) abaxially

17. Rhizomes very long-creeping (cord-like, ca. $0.2 \mathrm{~mm}$ diam.)

18. Pinnules abaxially hairy A. windischii

18. Pinnules abaxially scaly A. argutum

17. Rhizomes moderately long-creeping (stout, $0.3-0.5 \mathrm{~mm}$ diam.)

19. Rachises on both surfaces mostly with arachnoid scales and some lanceolate scales; indusia linear, lunate, usually one per pinnule A. pulverulentum

19. Rachises adaxially mostly with filiform scales (hairlike) and abaxially with lanceolate scales; indusia oblong, several per pinnule

20. Indusia glabrous

A. decoratum

20. Indusia hairy

A. tetraphyllum

Adiantum argutum Splitg., Tijdschr. Nat. Geschied. 7: 427, figs. 1, 2. 1840.

Figures: 42A, B

Habit/Habitat: Herb; terrestrial in forest on terra firme near stream margins.

Material examined: Bôca do Acre, G.T. Prance et al. 2533 (MG, NY); Cruzeiro do Sul, J. Prado et al. 1344 (SP, UFACPZ); Porto Acre, D.C. Daly et al. 7990 (UFACPZ); Rio Branco, D.C. Daly et al. 6675 (NY), S.R. Lowrie et al. 650 (GH, NY, R, RB, US); Sena Madureira, T.B. Croat \& A. Rosas Jr. 62716 (UFACPZ), M. Silveira et al. 668 (NY); Xapurri, D.C. Daly et al. 7261 (NY, UFACPZ), K.A. Kainer et al. 126 (NY), L.C. Ming et al. 356 (UFACPZ), M. Pinard 809 (NY).

World Distribution: Guianas, Brazil to Bolivia.

Characterized by very long-creeping rhizomes, 2-pinnate laminae, and acute or acuminate pinnules. Most similar is Adiantum latifolium, but A. argutum differs by pinnules abaxially with setiform scales on veins, margins of sterile pinnules conspicuously biserrate, and terminal pinnule larger than the others. For more details about this species, see Prado \& Lellinger (2002).

Adiantum cajennense Willd. ex Klotzsch, Linnaea 18: 552. 1844[1845].

Figures: 42C, D

Habit/Habitat: Herb; terrestrial in forest on terra firme on gently undulating terrain, canopy open.

Material examined: Cruzeiro do Sul, D.C. Daly et al. 11658 (NY), D.C. Daly et al. 11704 (NY), J. Prado et al. 1201 (SP, UFACPZ), J. Prado et al. 1293 (SP, UFACPZ); Mâncio Lima, J. Prado et al. 1140 (SP, UFACPZ);
Rodrigues Alves, J. Prado et al. 1233 (UFACPZ), J. Prado et al. 1245 (UFACPZ).

World Distribution: Guianas, Venezuela, Brazil to Bolivia.

Characterized by copiously scaly rachises, pinnules with sterile margins conspicuously denticulate-serrate, ca. $3 \times$ longer than wide, $30-45$ pairs per pinna, pinnules abaxially bearing scales on the veins, and indusia bearing scales with pectinate bases.

Adiantum decoratum Maxon \& Weath., Amer. J. Bot. 19(2): 165. 1932.

Figures: 42E, F

Habit/Habitat: Herb; terrestrial, forest in broad, meandering stream valleys in steeply hilly terrain.

Material examined: Santa Rosa, D.C. Daly et al. 10164 (NY), D.C. Daly et al. 11365 (NY).

World Distribution: Mexico, Mesoamerica, N South America.

Characterized by other 2-pinnate species of Adiantum in Acre by the presence of spreading, dense, filiform-subulate scales on the petioles and rachises. These scales are persistent and impar a shaggy appearance to the petioles (Mickel \& Smith 2004)

Adiantum diogoanum Glaz. ex Baker, J. Bot. 20: 310. 1882.

Figures: 42G, H

Habit/Habitat: Herb; terrestrial in forest on terra firme, on clay soils. Material examined: Bujari, D.C. Daly et al. 9385 (NY).

World Distribution: South America.

Characterized by short- to moderately long-creeping, nodose rhizomes; rachises scaly, the scales with pectinate base and denticulate margins; laminae 2-pinnate, with 3-5(-6) pairs of lateral pinnae; pinnules ca. $3 \times$ longer than wide, (16-)18-20 pairs per pinna, abaxially scaly on veins, the scales with pectinate bases; indusia pubescent with reddish brown hairs.

Adiantum dolosum Kunze, Linnaea 21: 219. 1848.

Figures: 43A, B

Habit/Habitat: Herb; terrestrial in forest on terra firme, on clay soils. Material examined: Rodrigues Alves, J. Prado et al. 1249 (SP, UFACPZ). World Distribution: South America.

Resembling Adiantum lucidum but differing by the usually 1-pinnate laminae, pinnae lanceolate, entire 6-9 $\times$ longer than wide, $4-5(-6)$ pairs, with bases approximately equal-sided, pinnae stalked ca. $1-3 \mathrm{~mm}$, abaxially bearing scales with pectinate bases, adaxially with scattered scales similar to abaxial ones; veins anastomosing; sori two, one on each side of a pinna, continuous, linear; indusia with reddish brown hairs.

Adiantum humile Kunze, Linnaea 9: 80. 1834.

Figures: 1A, 43C, D

Habit/Habitat: Herb; terrestrial in forest on terra firme, on clay soils. Material examined: Cruzeiro do Sul, J. Prado et al. 1302 (SP, UFACPZ), J. Prado et al. 1339 (SP, UFACPZ); Rodrigues Alves, J. Prado et al. 1246 (SP, UFACPZ).

World Distribution: Mesoamerica and tropical South America.

Characterized by sparsely hairy rachises and 2-4 pairs of lateral pinnae. Other characters are pinnules adaxially glabrous, abaxially glaucous and with long, septate, brown hairs; margins of sterile pinnules are finely serrate; indusia glabrous.

Adiantum latifolium Lam., Encycl. 1: 43. 1783.

Figures: 43E, F

Habit/Habitat: Herb; terrestrial in forest on terra firme, on sandy soils. Material examined: Cruzeiro do Sul, T.B. Croat \& A. Rosas Jr. 62393A (MO, UC, UFACPZ); J. Prado et al. 1294 (SP, UFACPZ); J. Prado et al. 
1374 (SP, UFACPZ); Manoel Urbano, D.C. Daly et al. 9149 (NY); Tarauacá, G.T. Prance et al. 7495 (GH, K, NY, R, UC, US).

World Distribution: Mexico, Antilles, Mesoamerica, and South America.

Characterized by long-creeping, cord-like rhizomes, lateral pinna pairs 1-4; pinnules 10-16 pairs per pinna, apices rounded to acute; pinnules glabrous on both surfaces, abaxially glaucous, margins of sterile pinnules finely serrulate. For comparative discussion of related species, see Prado \& Lellinger (2002).

Adiantum lucidum (Cav.) Sw., Syn. Fil. 121. 1806. Pteris lucida Cav., Descr. Pl. 266. 1802.

Figures: $43 \mathrm{G}, \mathrm{H}$

Habit/Habitat: Herb; terrestrial in forest on terra firme near stream margins.

Material examined: Rio Branco, C.S. Pessôa et al. 189 (NY).

World Distribution: Mesoamerica and N South America to Bolivia.

Characterized by pinnae (or pinnules) lanceolate, entire, $2-4 \times$ longer than wide, $10-13$ pairs, stalked ca. $1-3 \mathrm{~mm}$, abaxially with scattered scales, adaxially with very few similar scales; veins irregularly anastomosing, mostly free; sori 2 , one on each side of a pinna, continuous, usually not reaching pinna apices; indusia with reddish brown hairs.

Adiantum multisorum Samp., Relat. Commiss. Linhas. Estrateg. Matto Grosso Amazonas 5(Bot. pt. 7): 11, tab. 1, fig. 1. 1916.

Figures: 44C, D

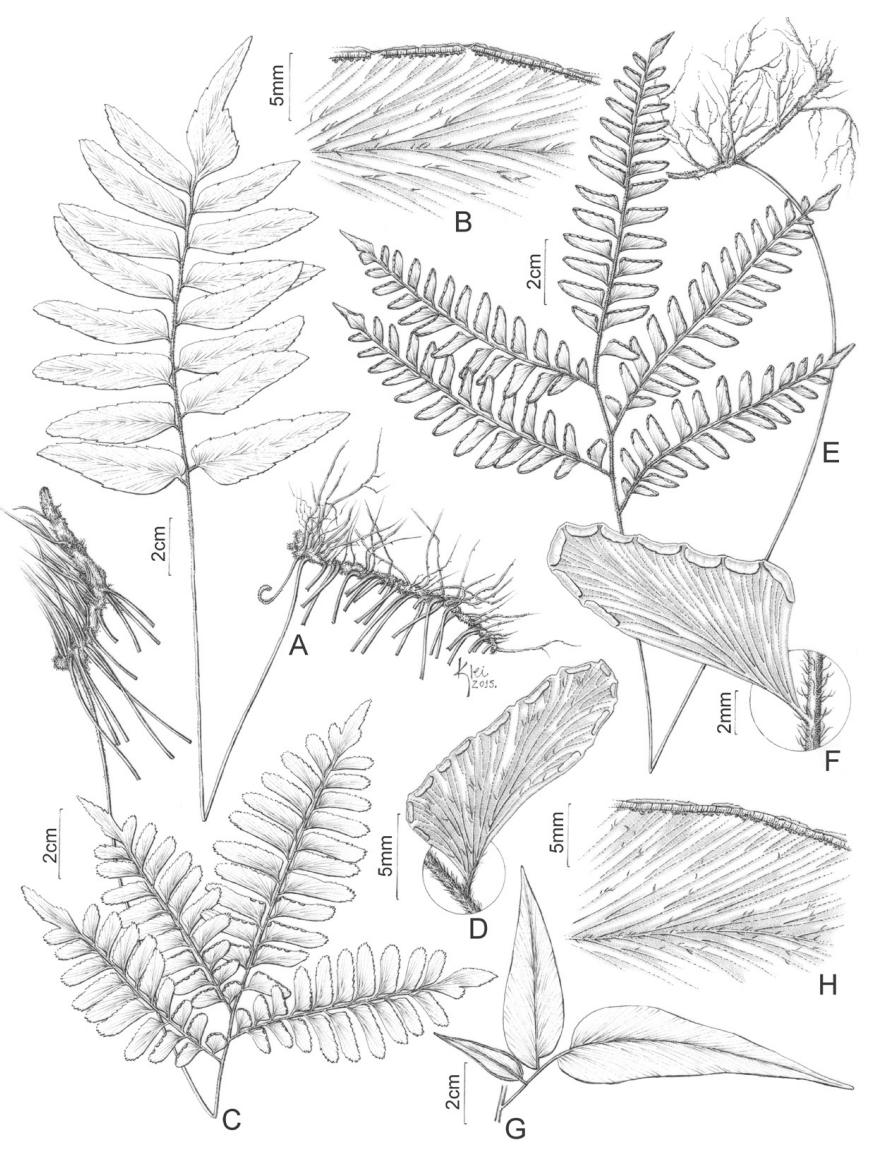

Figure 43. A, B. Adiantum dolosum. A. Habit (Prado et. al. 1249, SP). B. Fertile pinna (from Brazil, Espírito Santo, Sooretama, Salino \& Morais 4510, SP). C, D. Adiantum humile (Prado et al. 1302, SP). C. Habit. D. Fertile pinnule. E, F. Adiantum latifolum (Prado et al. 1294, NY). E. Habit. F. Fertile pinnule. G, H. Adiantum lucidum (Pessôa et al. 189, NY). G. Fertile pinnae. H. Fertile pinna.
Habit/Habitat: Herb; terrestrial in forest on terra firme.

Material examined: Cruzeiro do Sul, J. Prado et al. 1358 (SP, UFACPZ).

World Distribution: N South America to Bolivia.

Similar to Adiantum tetraphyllum. Characterized by the rhizomes stout, short-creeping, nodose; rachises copiously scaly, scales with pectinate bases, ciliate margins, and filiform apices; laminae 2-pinnate, with 4 or 5 pairs of lateral pinnae; pinnules ca. $2 \times$ longer than wide, (20-)35-45 pairs per pinna, reduced toward pinna bases and apices, on both surfaces with scales on veins, margins of sterile pinnules serrate; sori contiguous; indusia oblong, bearing filiform scales.

Adiantum nudum A.R. Sm., Ann. Missouri Bot. Gard. 77(2): 260, fig. 6A, B. 1990.

Figures: 44A, B

Habit/Habitat: Herb; terrestrial in forest on terra firme near stream margins, on clay soils.

Material examined: Cruzeiro do Sul, W.C. Steward et al. P12679(NY); Mâncio Lima, D.C. Daly et al. 8854 (NY).

World Distribution: N South America to Bolivia.

Characterized by 1-pinnate laminae and glabrous petioles, rachises, and laminae. The lacking of indument on the axes distinguishes this species from Adiantum petiolatum, which has sparse scales and hairs on the petioles and rachises. Apparently, A. nudum grows only on clay soils near streams margins, whereas A. petiolatum grows on this and many other substrates.

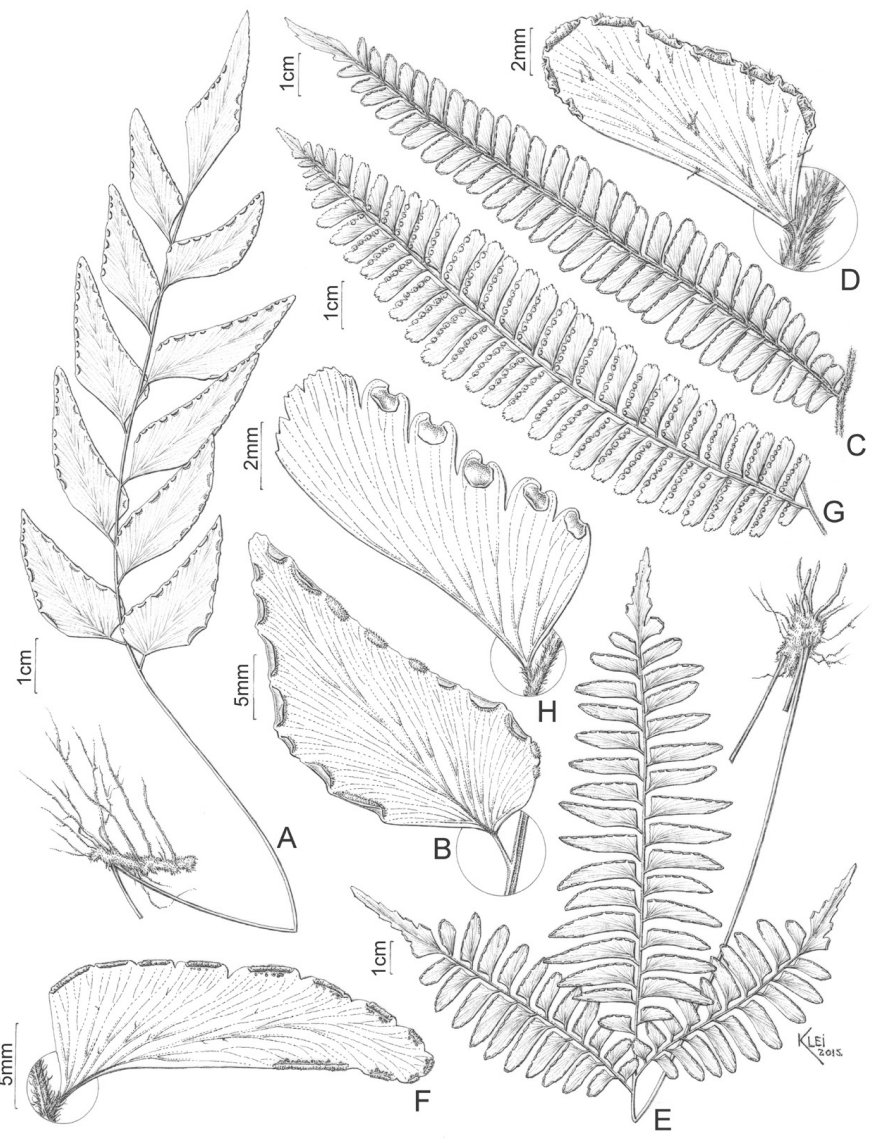

Figure 44. A, B. Adiantum nudum (Daly et al. 8854, NY). A. Habit. B. Fertile pinna. C, D. Adiantum multisorum (Prado et al. 1358, SP). C. Fertile pinna. D. Fertile pinnule. E, F. Adiantum obliquum (Prado et al. 1360, SP). E. Habit. F. Fertile pinnule. G, H. Adiantum pectinatum (Daly et al. 11474, NY). G. Fertile pinna. H. Fertile pinnule. 
Adiantum obliquum Willd., Sp. P1. 5(1): 429. 1810.

Figures: 44E, F

Habit/Habitat: Herb; terrestrial in forest on terra firme near stream margins.

Material examined: Cruzeiro do Sul, J. Jangoux et al. 85-008 (NY), J. Prado et al. 1345 (SP, UFACPZ); Rodrigues Alves, J. Prado et al. 1259 (UFACPZ); J. Prado et al. 1360 (SP, UFACPZ).

World Distribution: Mexico, Antilles, Mesoamerica, and tropical South America.

Characterized by rhizomes short-creeping, nodose; margins of sterile pinnae biserrate; laminae abaxially with conspicuous idioblasts between veins; indusia oblong, glabrous or with hairs.

Adiantum pectinatum Kunze ex Baker, Syn. Fil. 120. 1867.

Figures: 1B, 44G, H

Habit/Habitat: Herb; terrestrial on terra firme forest.

Material examined: Manoel Urbano, D.C. Daly et al. 11474 (NY).

World Distribution: Mesoamerica and tropical South America.

Distinguished from all other species of Adiantum in Acre by leaves 1-2 $\mathrm{m}$ long and (3-)4- or 5-pinnate. Also characterized by stout, short-creeping rhizomes; rachises with yellow-brown scales and ca. $1 \mathrm{~mm}$ long hairs, proximal pinnae the largest; pinnules stalked to $1 \mathrm{~mm}$ long, incised on acroscopic margins, abaxially with few hairs on proximal veins, adaxially glabrous; indusia orbicular, glabrous.

Adiantum petiolatum Desv., Ges. Naturf. Freunde Berlin Mag. Neuesten Entdeck. Gesammten Naturk. 5: 326. 1811.

Figures: 45A, B

Habit/Habitat: Herb; terrestrial, riverside vegetation.

Material examined: Basin of Rio Juruá, Rio Juruá Mirim and Igarapé Periquito (right-bank tributary), across from Santo Antônio, D.C. Daly et al. 11708 (NY); Mâncio Lima, J. Prado et al. 1139 (SP, UFACPZ); Manoel Urbano, D.C. Daly et al. 11528 (NY); Rodrigues Alves, J. Prado et al. 1275 (SP, UFACPZ).

World Distribution: Mexico, Antilles, Mesoamerica, and tropical South America.

Resembles Adiantum nudum by its 1-pinnate laminae, but differs by the rachises with filiform scales and hairs. The laminae are rarely 2-pinnate at base, and with 1 or 2 pairs of lateral pinnae; pinnae short-stalked or sessile, stalks ca. 1-4 mm long, midveins close to middle abaxially glabrous and laminae often glaucous, margins of sterile laminae serrulate; indusia linear-arcuate, glabrous.

Adiantum platyphyllum Sw., Kongl. Svenska Vetensk. Acad. Handl., n.s. 1817(1): 74, tab. 3, fig. 6. 1817.

Figures: $45 \mathrm{C}, \mathrm{D}$

Habit/Habitat: Herb; Steep, loamy river bank.

Material examined: Cruzeiro do Sul, W.C. Steward et al. P13241 (NY).

World Distribution: Ecuador to Bolivia and Brazil.

Characterized by glabrous rachises; pinnate (rarely 2-pinnate at base) laminae; pinnae not dimidiate, ovate-lanceolate, apices long-acute to long-acuminate, pinnae stalked, the stalks $0.5-2.5 \mathrm{~cm}$, color of stalks passing into pinna bases, abaxially decidedly glaucous and glabrous, sterile margins serrulate; veins ending in teeth at pinna margins; sori borne on acroscopic and basiscopic margins, sometimes at proximal margins; indusia oblong, short, linear-arcuate, glabrous.

Adiantum poeppigianum (Kuhn) Hieron., Hedwigia 48: 231. 1909. Adiantum lucidum var. poeppigianum Kuhn, Bot. Jahrb. Syst. 1:340. 1881.
Figures: $45 \mathrm{E}-\mathrm{G}$

Habit/Habitat: Herb; terrestrial in forest on steep slopes.

Material examined: Assis Brasil, D.C. Daly et al. 9810 (NY, UFACPZ); Manoel Urbano, D.C. Daly et al. 11473 (NY); Marechal Thaumaturgo, D.C. Daly et al. 10950 (NY); Sena Madureira, D.C. Daly et al. 7972 (NY); Santa Rosa, D.C. Daly et al. 10034 (NY).

World Distribution: South America.

Characterized by the usually 1-pinnate laminae and entire, lanceolate-cuneate to ovate-lanceolate pinnae, 3-4 × longer than wide, 5-10 pairs per frond. Rhizomes long-creeping, non-nodose; pinna bases asymmetric, subcordate, rounded on acroscopic sides and curved-cuneate on basiscopic sides, stalks ca. $1 \mathrm{~mm}$ long, color of stalks passing into pinnule bases; pinnae or pinnules abaxially with scattered scales on veins; veins free; sori 2 per pinna, one on each side, usually continuous (sometimes interrupted, forming 2 or 3 sori), linear, usually not reaching pinna apices; indusia glabrous.

Adiantum pulverulentum L., Sp. P1. 2: 1096. 1753.

Figures: 45H, I

Habit/Habitat: Herb; terrestrial in primary forest in low-lying area (Baixio) shallowly dissected by many small streams.

Material examined: Cruzeiro do Sul, D.C. Daly et al. 7365 (NY, UFACPZ), J. Prado et al. 1347 (SP, UFACPZ), G.T. Prance et al. 12065 (K, NY), G.T. Prance et al. $12065 a$ (NY), W.C. Steward et al. P12894 (K, NY);

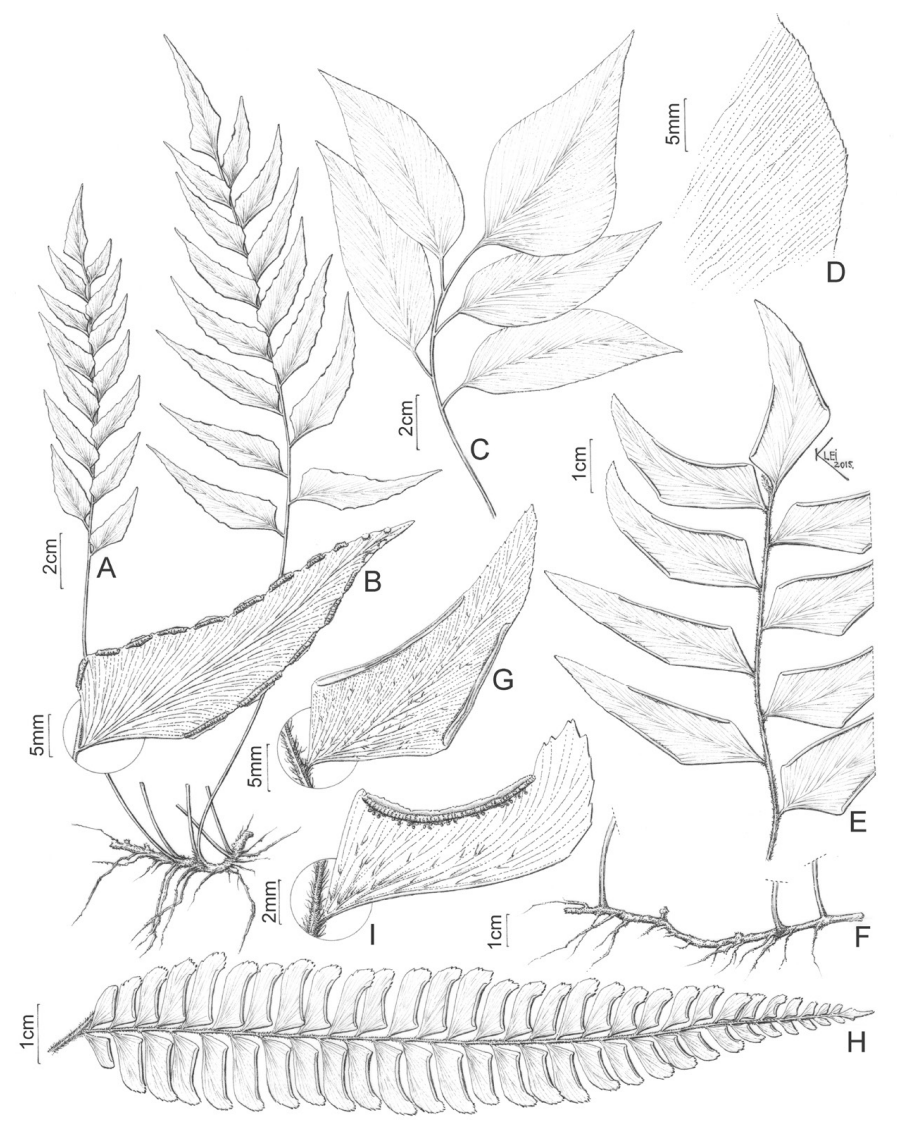

Figure 45. A, B. Adiantum petiolatum (Daly et al. 11708, NY). A. Habit. B. Fertile pinna. C, D. Adiantum platyphyllum (Steward et al. P13241, NY). C. Sterile pinnae. D. Venation. E-G. Adiantum poeppigianum (Daly et al. 11473, NY). E. Part of a fertile frond. F. Rhizome. G. Fertile pinna H, I. Adiantum pulverulentum (Daly et al. 7365, NY). H. Fertile pinna. I. Fertile pinnule. 
Manoel Urbano, D.C. Daly et al. 9173 (NY), D.C. Daly et al. 11392 (NY); Rio Azul, J. Jangoux et al. 85-064 (NY); Rio Branco, S.R. Lowrie et al. 649 (GH, NY, R, US); Tarauacá, C. Figueiredo et al. 883 (NY); Santa Rosa, D.C. Daly et al. 10050 (NY), D.C. Daly et al. 11004 (NY); Rio Juruá between Mundurucus \& Tatajuba, P.J.M. Maas et al. P12894 (GH, K, NY, R, US).

World Distribution: Mexico, Antilles, Mesoamerica, and tropical South America.

Characterized by 2-pinnate laminae with a conform terminal pinna, and a single linear, lunate indusium along the acroscopic side of the pinnules. Other distinctive characters of the species are rhizomes moderately long-creeping; lateral pinna pairs 3-8(-10); rachises with two kinds of scales: lanceolate with denticulate margins and arachnoid; pinnules 2-3 $\times$ longer than wide, 25-35 pairs per pinna, reduced toward pinna apices, pinnules abaxially with scales on veins, margins of sterile pinnules serrate.

Adiantum scalare R.M. Tryon, Amer. Fern J. 47: 141, tab. 15. 1957.

Figures: 46A, B

Habit/Habitat: Herb; terrestrial in moist forest on terra firme, undulating terrain.

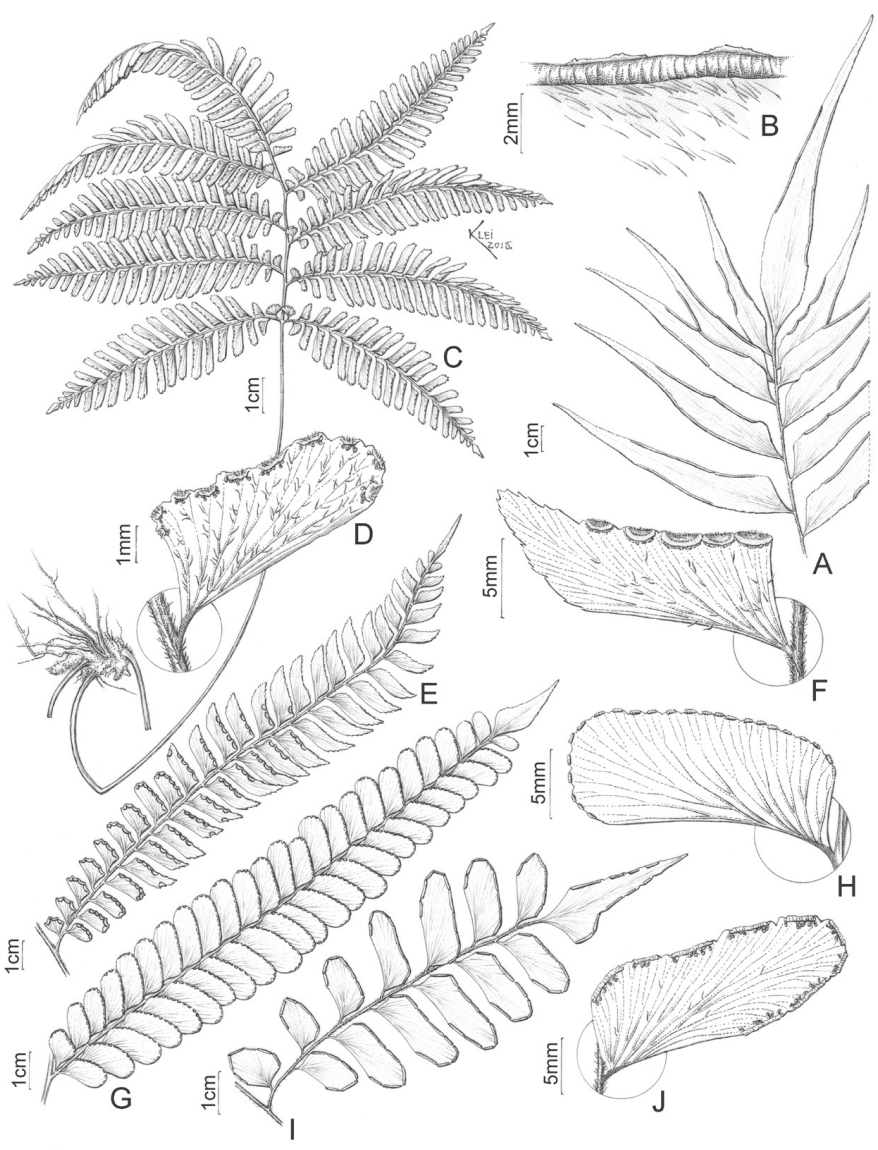

Figure 46. A, B. Adiantum scalare (Prance et al. 7335, NY). A. Part of a fertile frond. B. Sorus. C, D. Adiantum terminatum (Prado et al. 1303, SP). C. Habit. D. Fertile pinnule. E, F. Adiantum tetraphyllum (Daly et al. 11878, NY). E. Fertile pinna. F. Fertile pinnule G, H. Adiantum tomentosum (Prado et al. 1195, SP). G. Fertile pinna. H. Fertile pinnule. I, J. Adiantum windischii (Prado et al. 1276, SP). I. Fertile pinna. J. Fertile pinnule.
Material examined: Cruzeiro do Sul, D.C. Daly et al. 7331 (NY); Marechal Thaumaturgo, D.C. Daly et al. 10304 (NY); Tarauacá, G.T. Prance et al. 7335 (K, NY).

World Distribution: N South America to Bolivia.

Characterized by two sori, one on each side of a pinna, continuous, linear, usually not reaching the pinna apex and base; indusia densely pilose, hairs reddish brown. Also, this species has short-creeping, nodose rhizomes; rachis scales lanceolate with copiously ciliate margins; laminae pinnate, pinnae narrowly long-triangular, entire, 6-8 $\times$ longer than wide, 7-10 pairs per frond, stalked ca. 1-3 mm, apices long-attenuate, pubescent on both surfaces, hairs 1-2 mm long; veins irregularly anastomosing, mostly free.

Adiantum terminatum Kunze ex Miq., Verslagen Meded. Vier K1. Kon. Ned. Inst. Wetensch. Letterk. Schoone Kunsten 1842: 187. 1843.

Figures: 46C, D

Habit/Habitat: Herb; terrestrial in forest on terra firme, on clay soils.

Material examined: Cruzeiro do Sul, J. Jangoux et al. 85-009 (NY), J. Prado et al. 1303 (SP, UFACPZ), J. Prado et al. 1354 (SP, UFACPZ), G.T. Prance et al. 12203 (INPA, MO, NY); Porto Valter, D.C. Daly et al. 11786 (NY), D.C. Daly et al. 11788 (NY); Rodrigues Alves, J. Prado et al. 1361 (SP, UFACPZ).

World Distribution: Mexico, Antilles, Mesoamerica, and tropical South America.

Resembles Adiantum humile by its small size and pinnules abaxially with long, septate, brown hairs, adaxially glabrous, and by the finely serrulate margins of sterile pinnules. Also, the rhizomes are short-creeping, nodose, and rachises sparsely scaly by narrowly lanceolate scales. However, A. terminatum differs by pinnules reduced toward pinna bases and apices, distal pinnules less than half the size of largest ones, and indusia with reddish brown hairs.

Adiantum tetraphyllum Humb. \& Bonpl. ex Willd., Sp. Pl., ed. 4 [Willdenow], 5(1): 441. 1810.

Figures: 46E, F

Habit/Habitat: Herb; terrestrial in forest on terra firme, on clay soils. Material examined: Brasiléia, D.C. Daly et al. 11878 (NY).

World Distribution: Mexico, Antilles, Mesoamerica, and tropical South America.

A widespread and highly variable species. Similar to Adiantum diogoanum but differs most conspicuously by the acute pinnules curved toward pinna apices. Other distinctive characters are: Rhizomes moderately long-creeping; rachises with two kinds of scales: most scales filiform (hairlike) adaxially, lanceolate with pectinate bases abaxially; laminae with 3-6(-7) pairs of lateral pinnae; pinnules ca. 3-4 × longer than wide, 16-30 pairs per pinna, reduced toward pinna bases and apices, margins of sterile pinnules serrate to biserrate, pinnules abaxially with few scales on veins, indusia oblong, with reddish brown hairs.

Adiantum tomentosum Klotzsch, Linnaea 18: 553. 1844[1845].

Figures: 46G, H

Habit/Habitat: Herb; terrestrial in forest on terra firme, on clay soils.

Material examined: Cruzeiro do Sul, P.J.M. Maas et al. P12791 (NY); J. Prado et al. 1165 (SP, UFACPZ), J. Prado et al. 1195 (SP, UFACPZ), G.T. Prance 11390 (MG, NY), P.G. Windisch 2574 (HB, HRCB); Porto Valter, D.C. Daly et al. 7578 (NY, UFACPZ); Rodrigues Alves, J. Prado et al. 1242 (UFACPZ).

World Distribution: Tropical South America.

Characterized by pinnae with 30-35 pairs of imbricate obtuse pinnules, and rachises and costae glabrous abaxially but puberulent adaxially with hairs 
less than $0.1 \mathrm{~mm}$ long. Further distinguished from other 2-pinnate species by lacking idioblasts in the laminae, and lacking scales on the rachises.

Adiantum windischii J. Prado, Kew Bull. 60(1): 119-121, fig. 2. 2005.

Figures: 46I, J

Habit/Habitat: Herb; terrestrial in forest on terra firme, on clay soils. Material examined: Cruzeiro do Sul, G.T. Prance et al. P13045 (UC); Rodrigues Alves, J. Prado et al. 1276 (SP, UFACPZ).

World Distribution: Tropical South America.

Resembling Adiantum humile, A. latifolium, and A. terminatum, but differing by long-creeping, cord-like rhizomes, and rachises with two kinds of scales: arachnoid, and lanceolate with pectinate bases and filiform apices; lateral pinnae 1-3 pairs, with pinnules reduced toward apices, 14-16 pairs per pinna, margins of sterile pinnules finely serrate, apices rounded, abaxially with long, septate reddish brown hairs on veins, adaxially glabrous; indusia glabrous.

Ananthacorus Underw. \& Maxon, Contr. U.S. Natl. Herb. 10: 487. 1908.

Characterized by narrowly elliptic-linear leaves, several rows of areoles between the costae and margins, and sori parallel to the laminar margins. The areolate veins are often difficult to see because of the thick lamina. Vittaria is similar but has narrower $(2-5 \mathrm{~mm}$ wide) leaves.

Neotropical; 1 species.

Ananthacorus angustifolius (Sw.) Underw. \& Maxon, Contr. U.S. Natl. Herb. 10: 487. 1908. Pteris angustifolia Sw., Prodr. 129. 1788.

Figure: 47A

Habit/Habitat: Herb; epiphyte in forest on terra firme.

Material examined: Bujari, D.C. Daly et al. 9336 (NY); Cruzeiro do Sul, D.C. Daly et al. 7495 (NY, UFACPZ), G.T. Prance et al. 12616 (MG, NY); Rio Branco, B. Nelson 739 (MG, NY); Santa Rosa, D.C. Daly et al. 10160 (NY); Sena Madureira, M. Silveira et al. 615 (NY, UFACPZ); Tarauacá, D.C. Daly et al. 8737 (NY, UFACPZ), G.T. Prance et al. 7379 (MG, NY).

World Distribution: Mexico, Antilles, and N South America to Bolivia.

Characterized by thick laminae, 2 or 3 rows of areoles between the costa and margin (these often hard to see because of the thick laminae), sori submarginal on each side of the costa, nearly continuous, indusia absent with paraphyses abundant, slender, without a swollen apical cell.

Hecistopteris J. Sm., London J. Bot. 1: 193. 1842.

Hecistopteris can be characterized by the distally furcate leaves only 1-4 cm long, and veins free. The plants epiphytic on the base of trunks in dark places.

Neotropical; 3 species, 1 in Acre

Hecistopteris pumila (Spreng.) J. Sm., London J. Bot. 1: 193. 1842. Gymnogramma pumila Spreng., Tent. Suppl. 31. 1828.

Figures: 47D, E

Habit/Habitat: Herb; epiphyte on the base of trunks in forest on terra firme.

Material examined: Cruzeiro do Sul, J. Prado et al. 1208 (UFACPZ), J. Prado et al. 1336 (SP, UFACPZ), J. Prado et al. 1386 (SP, UFACPZ).

World Distribution: Mexico, Antilles, Mesoamerica, and tropical South America.

Characterized by leaves only $1-2(-4) \mathrm{cm}$ long and short-incised apically. Some specimens have narrow and almost unforked lamina. Rhizomes are erect or ascending, with leaves clustered at the tip. Forming colonies by means of proliferous roots.

Hemionitis L., Sp. P1. 2: 1077. 1753.

Characterized by terrestrial habit, densely to sparsely hairy leaves, and sori following the veins. Further characterized by rhizomes erect to

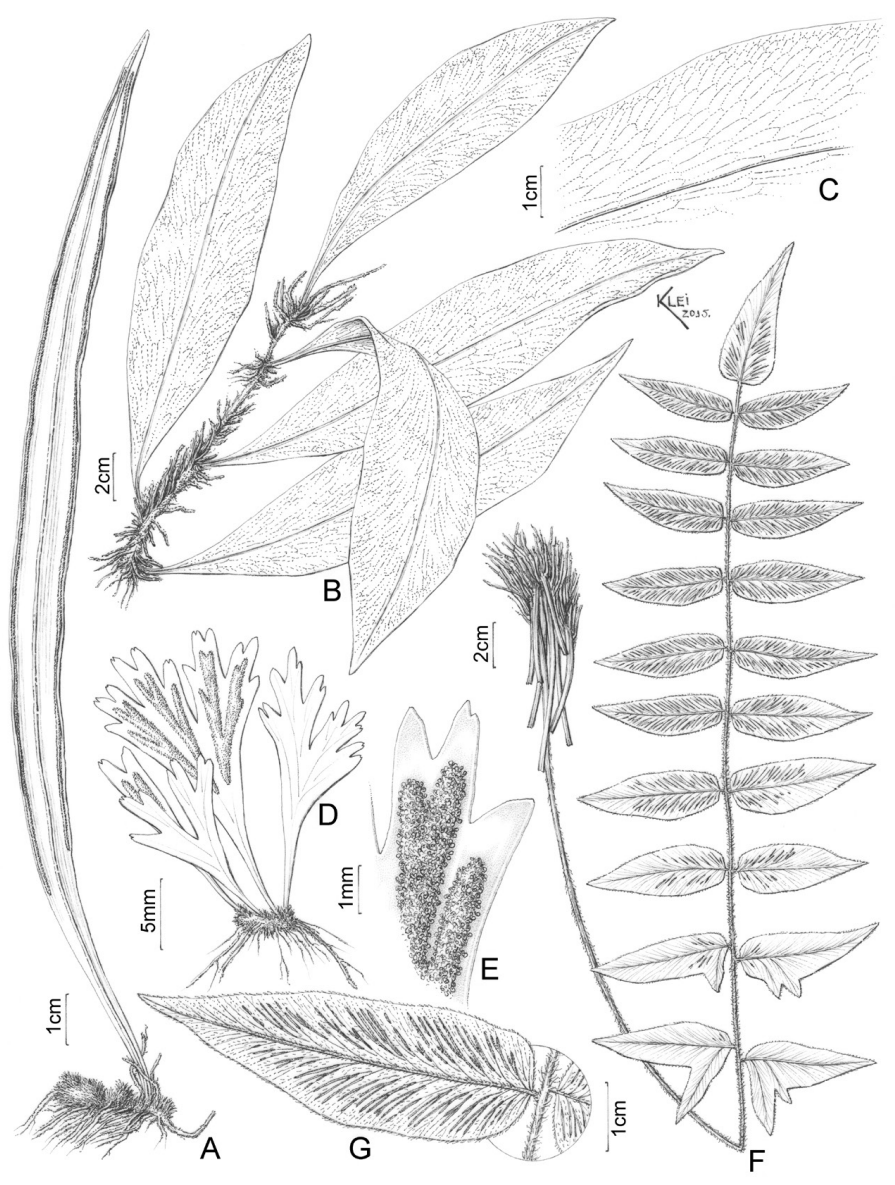

Figure 47. A. Ananthacorus angustifolius (Nelson 739, NY). A. Habit. B, C. Polytaenium citrifolium (Daly et al. 8269, NY). B. Habit. C. Venation. D, E. Hecistopteris pumila (Prado et al. 1386, SP). D. Habit. E. Sori. F, G. Hemionitis rufa (Alves et al. 2634, NY). F. Habit. G. Fertile pinna.

short-creeping, scaly, the scales concolorous or bicolorous, when bicolored with a dark central stripe, sterile and fertile leaves monomorphic or dimorphic, laminae simple, orbicular to 1- or 2-pinnate, the hairs acicular or glandular, veins areolate or free, if areolate the areoles without included veinlets, and indusia absent.

Neotropical; 5 species, 1 in Acre.

Hemionitis rufa (L.) Sw., J. Bot. (Schrader) 1800(2): 16. 1801. Pteris rufa L., Sp. Pl. 2: 1074. 1753.

Figures: 47F, G

Habit/Habitat: Herb; in open forest on terra firme.

Material examined: Porto Acre, M. Alves et al. 2634 (NY).

World Distribution: Mexico, Jamaica, Mesoamerica, and N South America to Bolivia.

Characterized by free veins and pubescent, 1-pinnate (or 2-pinnate) laminae. The color of the pinna stalks stop abruptly at pinna bases.

Pityrogramma Link, Handbuch 3: 19-20. 1833.

Characterized terrestrial habit, divided leaves, presence of usually whitish or yellowish farina on the abaxial surfaces of the laminae, sori spreading along the veins, and indusia absent.

Neotropical, adventive in Paleotropics; 20 species, 2 in Acre. 
1. Laminae 1-3-pinnate-pinnatifid; pinnae or pinnules pinnatifid to pinnatisect P. calomelanos

1. Laminae 1- or 2-pinnate; pinnae or pinnules entire ......P. trifoliata

Pityrogramma calomelanos (L.) Link, Handbuch 3: 20. 1833. Acrostichum calomelanos L., Sp. Pl. 2: 1072. 1753.

Figure: 48A

Habit/Habitat: Herb; terrestrial in forest on terra firme near river margins on clay soils.

Material examined: Assis Brasil, D.C. Daly et al. 9634 (NY, UFACPZ); Brasiléia, S.R. Lowrie et al. 696 (NY); Cruzeiro do Sul, J. Prado et al. 1173 (SP, UFACPZ), J. Prado et al. 1304 (SP, UFACPZ); Mâncio Lima, M. Silveira et al. 1294 (NY); Quixadá, E. Forero et al. 6381 (NY); Sena Madureira, M. Silveira et al. 670 (NY, UFACPZ); Tarauacá, G.T. Prance et al. $7302 A$ (NY), M. Silveira et al. 868 (NY).

World Distribution: S Florida, Mexico, Antilles, Mesoamerica and tropical South America.

Characterized by 1- or 2-pinnate-pinnatifid (rarely 3-pinnate-pinnatifid) laminae and ascending pinnules. In Acre the plants have whitish (not yellow) farina on the laminae abaxially.

Pityrogramma trifoliata (L.) R.M. Tryon, Contr. Gray Herb. 189: 68. 1962. Acrostichum trifoliatum L., Sp. Pl. 2: 1070. 1753.

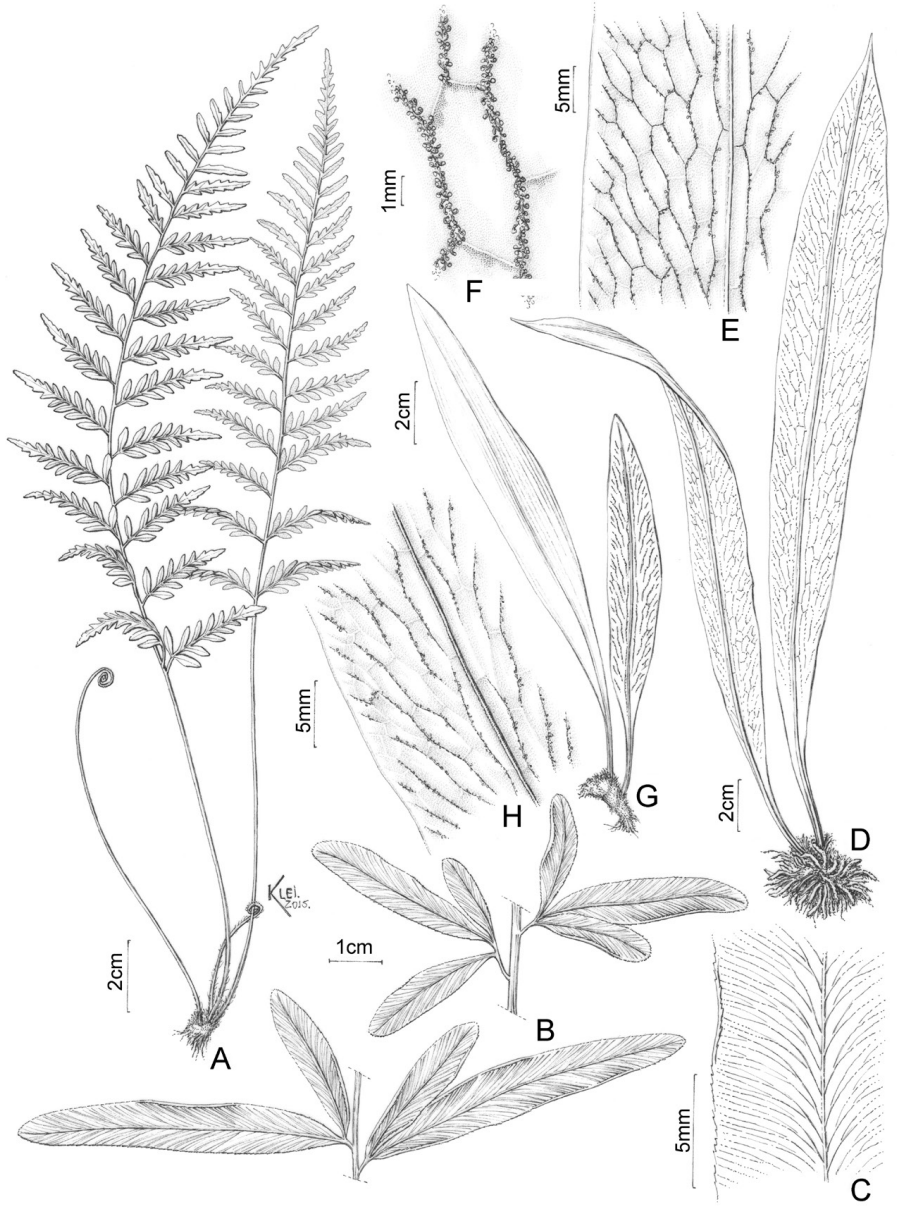

Figure 48. A. Pityrogramma calomelanos (Prado et al. 1304, SP). A. Habit. B, C. Pityrogramma trifoliata (from Brazil, Minas Gerais, Uberlândia, Ranal 1021, SP). B. Pinna. C. Venation. D-F. Polytaenium cajenense (Prance et al. 7342, NY). D. Habit. E. Venation. F. Sori. G, H. Polytaenium guayanense (Prado et al. 1240, SP). G. Habit. H. Fertile pinna.
Figures: 48B, C

Habit/Habitat: Herb; trails and roads through mixed forest and pastures. Material examined: Jordão, F.A. Michelangeli et al. 1351 (RB, NY).

World Distribution: Greater Antilles; S Mexico to Bolivia, Chile, N Argentina, Brazil, and Uruguay.

Distinguished by pinnae entire to 1-pinnate, when pinnate usually with only three pinnules. Laminae abaxially with yellow or whitish farina.

Polytaenium Desv., Mém. Soc. Linn. Paris 6: 174, 218. 1827.

Characterized by dorsiventral rhizomes with clathrate scales, leaves simple, entire, venation areolate, sori linear, along reticulate veins and, in one species, sporangia also distributed between veins, paraphyses present or absent and spores monolete or trilete. Typically low-trunk epiphytes in wet forests.

Polytaenium includes Anetium Splitg., a genus until recently considered distinct (Schuettpelz et al. 2016).

Neotropics; ca. 10 species, 3 in Acre.

1. Rhizomes long-creeping; sporangia on and between veins; spores monolete

P. citrifolium

1. Rhizomes short-creeping; sporangia on veins only; spores trilete

2. Sporangia in grooves; laminae dark greenish or blackish when dry, usually oblanceolate P. cajenense

2. Sporangia superficial; laminae yellowish-green when dry, usually oblong ......

P. guayanense

Polytaenium cajenense (Desv.) Benedict, Bull. Torrey Bot. Club 38: 169. 1911. Hemionitis cajenensis Desv., Ges. Naturf. Freunde Berlin Mag. Neuesten Entdeck. Gesammten Naturk. 5: 311. 1811.

Figures: 48D-F

Habit/Habitat: Herb; epiphyte in forest on terra firme.

Material examined: Cruzeiro do Sul, D.C. Daly et al. 11688 (NY); Feijó, P. Delprete et al. 8475 (NY), G.T. Prance et al. 7342 (NY); Mâncio Lima, D.C. Daly et al. 8962 (NY, UFACPZ); Marechal Thaumaturgo, D.C. Daly et al. 7350 (NY, UFACPZ), D.C. Daly et al. 10277 (NY); Porto Valter, M. Silveira et al. 1646 (NY); Santa Rosa, D.C. Daly et al. 11088 (NY), D.C. Daly et al. 10166 (NY), D.C. Daly et al. 11178 (NY); Tarauacá, D.C. Daly et al. 8619 (NY, UFACPZ), G.T. Prance 7267 A (NY); Without locality, J. Jangoux 85-095 (NY).

World Distribution: Mexico, Antilles, Mesoamerica, and tropical South America.

Characterized by sori sunken in grooves along the veins (magnification needed). The laminae often dry dark greenish or blackish and are oblanceolate, being widest above the middle.

Polytaenium citrifolium (L.) Schuettp., Taxon 65(4): 719. 2016. Acrostichum citrifolium L., Sp. P1. 2: 1067. 1753.

Figures: 47B, C

Habit/Habitat: Herb; epiphyte in forest on terra firme.

Material examined: Tarauacá, D.C. Daly et al. 8269 (NY), G.T. Prance et al. 7426 (MG, NY).

World Distribution: Mexico, Mesoamerica, and tropical South America.

Characterized by long-creeping rhizomes, distinctly clathrate scales, and sporangia occurring sparsely on the laminar tissue between the veins. Until recently, this species was treated as Anetium citrifolium (L.) Splitg.

Polytaenium guayanense (Hieron.) Alston, Kew Bull. 1932(7): 134. 1932. Anthrophyum guayanense Hieron., Hedwigia 57: 212. 1915.

Figures: 48G, H

Habit/Habitat: Herb; epiphyte in forest on terra firme. 
Material examined: Cruzeiro do Sul, J. Prado et al. 1316 (UFACPZ), J. Prado et al. 1351 (UFACPZ); Marechal Thaumaturgo, D.C. Daly et al. 10254 (NY), D.C. Daly et al. 10837 (NY); Porto Valter, W.C. Steward et al. P13013 (MG, NY); Rodrigues Alves, J. Prado et al. 1240 (SP, UFACPZ), J. Prado et al. 1248 (SP, UFACPZ), J. Prado et al. 1277 (SP, UFACPZ); Without locality, J. Jangoux et al. 85-026 (NY), J. Jangoux et al. 85-095A (NY).

World Distribution: N South America to Bolivia.

Characterized by laminae that dry yellowish green, not dark green or blackish, and widest at or near the middle.

\section{Pteris L., Sp. Pl. 2: 1073. 1753.}

Characterized by short-creeping to erect, compact rhizomes bearing scales at apices; laminae medium-sized to large, clumped, monomorphic, laminae pinnate to several times pinnate, pentagonal to pedate, usually proximal pinna-pair elaborated basally, venation free or anastomosing, without included free veinlets, sori on a marginal commissure connecting the vein ends, with paraphyses, indusia formed by the differentiated and recurved margins. Prado \& Windisch (2000) revised the Brazilian species of Pteris.

Pantropical; ca. 250 species (ca. 60 Neotropical), 7 in Acre.

1. Venation free

2. Median pinnae entire; petioles without spines P. vittata

2. Median pinnae pinnatifid; petioles spiny

P. pungens

1. Venation areolate or at least partially so

3. Venation partially areolate (all areoles joined to the costa and/or costule base, with veins free between those areoles and the pinna margins)

P. tripartita

3. Venation areolate (areoles joined to the costa and costule, and to each other, with veins free only near the pinna margins)

4. Laminae 1-pinnate or 2-pinnate, pinnae and pinnules entire

5. Proximal pinnae 1-pinnate; several series of areoles (approximately isodiametric) between the costa and pinna margins

P. haenkeana

5. Proximal pinnae entire or furcate; large and elongate areoles oblique to the costa and reducing in size towards the pinna margins

P. grandifolia

4. Laminae 1- or 2-pinnate-pinnatifid; pinnae and pinnules deeply pinnatifid to pinnatisect, or pinnatifid only on the basiscopic side
6. Areoles 1 between two adjacent costules
P. propinqua

6. Areoles 2 or 3(-4) between adjacent costules

P. altissima

Pteris altissima Poir., Encycl. 5: 722. 1804.

Figures: 49A, B

Habit/Habitat: Herb; terrestrial in forested slope between Baixio and higher terrace, canopy relatively closed, understory relatively rich in herbs.

Material examined: Brasiléia, D.C. Daly et al. 9879 (NY, UFACPZ); Jordão, R. Goldenberg et al. 1304 (NY); Manoel Urbano, D.C. Daly et al. 9086 (NY), D.C. Daly et al. 11195 (NY), D.C. Daly et al. 11260 (NY), D.C. Daly et al. 11422 (NY); Marechal Thaumaturgo, D.C. Daly et al. 7702 (NY); Santa Rosa, D.C. Daly et al. 10054 (NY, UFACPZ); Tarauacá, D.C. Daly et al. 8317 (NY), G.T. Prance et al. 799 (NY), G.T. Prance et al. 7259 (INPA, K, NY, US, R), G.T. Prance et al. 7299 (NY), M. Silveira et al. 997 (NY); Without locality, J. Jangoux et al. 85-063 (NY).

World Distribution: Mexico, Antilles, Mesoamerica, and tropical South America.
Characterized by slightly pedate, 2-pinnate-pinnatifid leaves; stalked proximal pinnae, the stalks ca. $0.5 \mathrm{~cm}$ long, not winged, areolate venation with 2 or 3(-4) areoles adjoining the costa between two adjacent costules, and the presence of short green awns at the junctures of the costae and costules adaxially.

Pteris grandifolia L., Sp. P1. 2: 1073-1074. 1753.

Figures: 49C, D

Habit/Habitat: Herb; terrestrial on substrate hard and brittle, near clear water.

Material examined: Cruzeiro do Sul, D.C. Daly et al. 11697 (NY); Marechal Thaumaturgo, D.C. Daly et al. 10198 (NY); Porto Valter, P.J.M. Maas et al. 13239 (K, NY).

World Distribution: Mexico, Antilles, Mesoamerica, and N South America to Bolivia.

Characterized by 1-pinnate leaves with a conform terminal segment, entire pinnae, and areolate venation. The areoles are large, elongate, and oriented obliquely to the costa, becoming reduced in size towards the pinna margins.

Pteris haenkeana C. Presl, Reliq. Haenk. 1(1): 55. 1825.

Figures: 49E, F

Habit/Habitat: Herb; terrestrial in moist forest on terra firme, tertiary sediments, undulating terrain.

Material examined: Assis Brasil, D.C. Daly et al. 9791 (NY, UFACPZ); Manoel Urbano, D.C. Daly et al. 11426 (NY); Marechal Thaumaturgo, D.C. Daly et al. 7341 (NY); Santa Rosa, D.C. Daly et al. 11314 (NY).

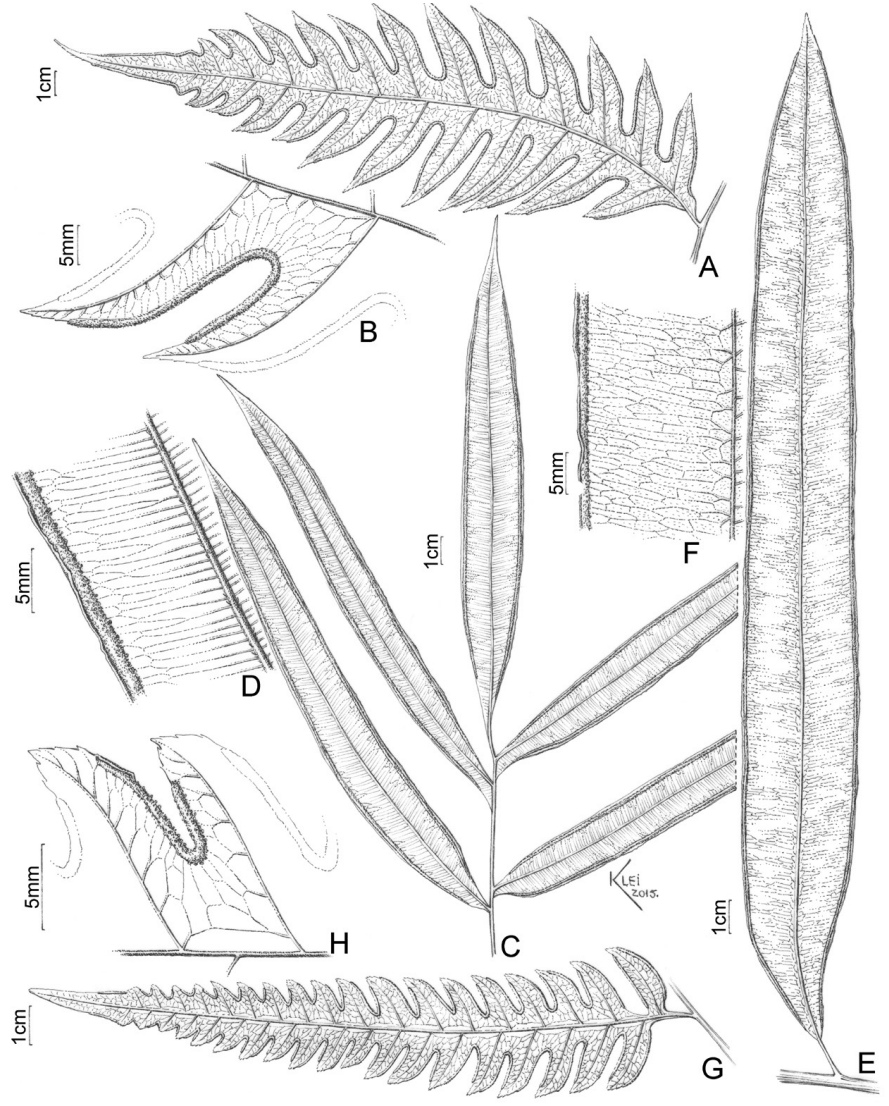

Figure 49. A, B. Pteris altissima (Goldenberg et al. 1304, NY). A. Pinna. B. Fertile pinna. C, D. Pteris grandifolia (Daly et al. 11697, NY). C. Part of a frond. D. Fertile pinna. E, F. Pteris haenkeana (Daly et al. 11314, NY). E. Pinna. F. Fertile pinna. G, H. Pteris propinqua (Daly et al. 11475, NY). G. Pinna. H. Fertile pinna. 
World Distribution: N South America to Bolivia.

Characterized by usually 2-pinnate leaves with conform apices, entire pinnae (long-lanceolate or oblong-lanceolate), areolate venation with several series of areoles (approximately isodiametric) between the costa and pinna margins, and serrate pinnae. In Brazil, this species is known only in Acre (Prado \& Windisch 2000).

Pteris propinqua J. Agardh, Recens. Spec. Pter. 65. 1839.

Figures: 49G, H

Habit/Habitat: Herb; terrestrial in undisturbed forest in low-lying areas with moist soils, canopy open.

Material examined: Manoel Urbano, D.C. Daly et al. 11475 (NY); Marechal Thaumaturgo, D.C. Daly et al. 10465 (NY); Rio Branco, L. Coêlho \& A. Rosas Jr. 1941 (NY, UFACPZ); Sena Madureira, D.C. Daly et al. 7920 (MO).

World Distribution: Mexico, Mesoamerica, and tropical South America.

Characterized by laminae 2-pinnate-pinnatifid; stalked proximal pinnae, the stalks (1-2.5 cm long) bordered by a narrow green wing decurrent onto the rachis; venation areolate, with one large areole joined to the costa between two adjacent costules; awns present on the adaxial side of costae.

Pteris pungens Willd., Sp. P1. 5(1): 387. 1810.

Habit/Habitat: Herb.; on terra firme, near margins of streams.

Material examined: Rio Acre, J. Jangoux et al. 85-099 (NY).

World Distribution: Mexico, Antilles, Mesoamerica, and tropical South America.

Differing from all other species of Pteris in Acre by spiny petioles; free venation, with basal simple or furcate veins arising from the costae and costules, caudate apical segments, and costules awned on the adaxial surface. Also distinctive are 1-pinnate-pinnatifid leaves and furcate proximal pinnae.

Pteris tripartita Sw., J. Bot. Schrader 1800(2): 67. 1801.

Habit/Habitat: Herb; disturbed primary forest.

Material examined: Rio Branco, T.B. Croat 86100 (NY).

World Distribution: Introduced and widely naturalized in the Neotropics: Mesoamerica, Antilles, and widespread in South America.

Distinguished by tripartite, 1- or 2-pinnate-pinnatifid leaves, and partially areolate venation, with two large areoles adjacent to the costa between two adjacent costules.

Pteris vittata L., Sp. Pl. 2: 1074. 1753.

Habit/Habitat: Herb; along trail in disturbed area in the Federal University of Acre (UFAC).

Material examined: Rio Branco, T.B. Croat 86081 (NY).

World Distribution: Pantropical, introduced and widespread in the Neotropics.

Characterized by 1-pinnate leaves with a conform apical segment, linear pinnae, not articulate to the rachis and with truncate base, and free venation with simple or furcate veins. The pinnae display wide variation in size, angle of divergence from the rachis (acute or right angle), and shape (straight to shortly falcate).

Vittaria Sm., Mém. Acad. Roy. Sci. (Turin) 5: 413, tab. 9, fig. 5. 1793.

Characterized by distichous leaves, dark purplish brown petioles, linear laminae less than $5 \mathrm{~mm}$ wide, and paraphyses with a slender apical cell (not obconic).

Pantropical; 7 species, 1 in Acre.

Vittaria lineata (L.) Sm., Mém. Acad. Roy. Sci. (Turin) 5(1790-1791): 421, tab. 9, fig. 5. 1793. Pteris lineata L., Sp. Pl. 2: 1073. 1753.

Habit/Habitat: Herb; epiphyte in forest, often in canopy and in the axils of old palm leaves and sometimes on low trunks.
Material examined: Cruzeiro do Sul, P.J.M. Maas et al. P12768 (NY); Mâncio Lima, J. Prado et al. 1227 (SP, UFACPZ); Rodrigues Alves, J. Prado et al. 1279 (SP, UFACPZ).

World Distribution: Mexico, Antilles, Mesoamerica, and tropical South America.

Characterized by linear leaves $2-3 \mathrm{~mm}$ wide, sori linear, in one row between the rachis and margin, parallel to the margin, sunken in a groove, paraphyses with a slender or slightly clavate apical cell, spores monolete. The stomata are restricted to the soral groove; they do not occur on the abaxial surface of the laminae as in other ferns (Britton \& Taylor 1902).

\section{SACCOLOMATACEAE}

Characterized by compact rhizomes densely surrounded by old petiole bases, and petioles in cross-section with an omega-shaped $(\Omega)$ vascular bundle (the open end of the omega oriented adaxially). In Acre, only Pteris and the Dennstaedtiaceae have an omega-shaped vascular bundle. Another highly distinctive character is that the rhizome in cross section reveals two rings of vascular tissue (dicyclic). Pteris differs by marginal sori with a false indusium, and often by short green awns adaxially at the junctures of the costae and costules. The Dennsteadtiaceae, which also have an omega-shaped petiolar vascular bundle, differ by long-creeping pubescent (not scaly) rhizomes and epipetiolar buds on the sides of the petiole bases.

Pantropical; 1 genus, ca. 18 species. In Acre, 3 species.

Saccoloma Kaulf., Berlin. Jahrb. Pharm. Verbundenen Wiss. 21: 51. 1820. Same characters as those of the family.

1. Laminae 3- or 4-pinnate S. inaequale

1. Laminae 1-pinnate

2. Pinnae 20-25 $\times 2.5-3 \mathrm{~cm}$, entire; sori marginal ...... S. chartaceum

2. Pinnae $1-1.5 \times 0.5 \mathrm{~cm}$, pinnatifid or lobate; sori submarginal ...... S. membranaceum

Saccoloma chartaceum G.B. Nair, J. Bombay Nat. Hist. Soc. 86(3): 415. 1989.

Figures: 50A, B

Habit/Habitat: Herb; terrestrial in forest on terra firme.

Material examined: Cruzeiro do Sul, J. Prado et al. 1341 (SP, UFACPZ); Sena Madureira, C.A. Cid \& B. Nelson 2574 (NY); Without locality, J. Jangoux et al. 85-100 (MG, NY).

World Distribution: Mexico, Antilles, Mesoamerica, and tropical South America.

Characterized by imparipinnate laminae, pinnae $20-25 \times 2.5-3 \mathrm{~cm}$, entire, and marginal sori.

Saccoloma inaequale (Kunze) Mett., Ann. Sci. Nat., Bot., sér. 4, 15: 80. 1861. Davallia inaequalis Kunze, Linnaea 9: 87. 1834.

Figures: 1H, 50C, D

Habit/Habitat: Herb; terrestrial and common on terra firme forest on high terrace.

Material examined: Bujari, D.C. Daly et al. 9456 (NY); Cruzeiro do Sul, J. Prado et al. 1203 (SP, UFACPZ), G.T. Prance et al. 12194 (MG, NY), G.T. Prance et al. 12333 (NY), G.T. Prance et al. 12574 (NY); Rodrigues Alves, J. Prado et al. 1256 (SP, UFACPZ); Santa Lucia, J. Pruski et al. 3497 (NY); Without locality, J. Jangoux et al. 85-011 (NY).

World Distribution: Mexico, Antilles, Mesoamerica, and tropical South America. 
Prado, J. et al.

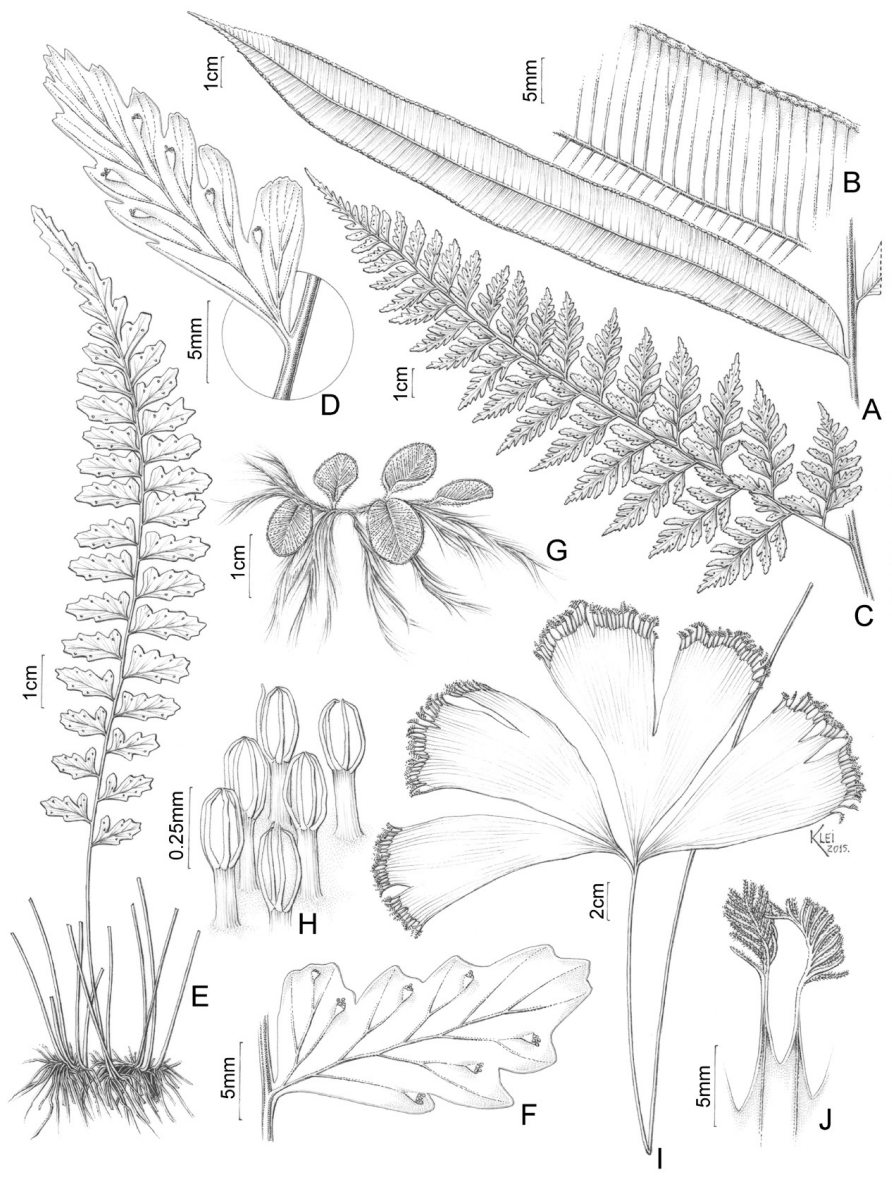

Figure 50. A, B. Saccoloma chartaceum (Prado et al. 1341, SP). A. Fertile pinna. B. Fertile pinna. C, D. Saccoloma inaequale (Prado et al. 1203, SP). C. Fertile pinna. D. Fertile pinnule. E, F. Saccoloma membranaceum (Prance et al. 12432, NY, holotype). E. Habit. F. Fertile pinna. G, H. Salvinia radula (Prado et al. 1378, SP). G. Habit. H. Hairs from adaxial surface. I, J. Schizaea elegans (Prado et al. 1162, SP). I. Fertile frond. J. Sori.

Characterized by erect rhizomes, 3- to 4-pinnate leaves, and pocket-like submarginal sori that are raised (embossed) on the adaxial surface of the lamina.

Saccoloma membranaceum Mickel, Amer. Fern J. 74(4): 119, fig. 2A, B. 1984.

Figures: 50E, F

Habit/Habitat: Herb; terrestrial in montane forests.

Material examined: Cruzeiro do Sul, G.T. Prance et al. 12432 (NY).

World Distribution: Amazonian Peru and Brazil.

Characterized by membranous leaves, $10-15 \mathrm{~cm}$ long and pinnae $1-1.5 \times 0.5 \mathrm{~cm}$, pinnatifid or lobate. The type was collected in Acre and is the only collection of this species from the state.

\section{SALVINIACEAE}

Characterized by free-floating habit, small size, and rounded leaves bearing hairs or papillae on the upper surfaces. Further characterized by rhizomes thin, long-creeping, frequently branched, and easily breaking. Leaves 1-30 mm long, not circinate. Sori on the submerged (ventral) side of the plant of two types, either megasporangiate or microsporangiate, borne at the vein tips; indusia thin, globose, whitish. Sporangia staked; annulus absent. Spores trilete, non-green. Megasporangia one-spored at maturity.
Temperate and tropical regions worldwide; 2 genera, 21 species. In Acre, 1 genus, 1 species.

Salvinia Ség., Fl. Veron. 3: 52. 1754.

Floating aquatics with two roundish green leaves on the surface of the water and a third leaf submerged, finely dissected, whitish, and root-like. Further characters are roots absent; stems hairy, thin, branched; floating leaves $0.4-3 \mathrm{~cm}$ in diameter, circular, ovate or oblong, entire, typically with papillae on the upper surface, the papillae when present with 3 or 4 hairs at their apices, these usually united and darkened at the apex, forming a cage; veins anastomosing, the areoles elongate, polygonal, without included veinlets; sori borne on the submerged leaf; indusia globose, whitish.

Pantropical, 9 species, 1 in Acre.

Salvinia radula Baker, J. Bot. 24: 98. 1886.

Figures: $50 \mathrm{G}, \mathrm{H}$

Habit/Habitat: Herb; aquatic in lakes along road margins.

Material examined: Cruzeiro do Sul, J. Prado et al. 1378 (SP, UFACPZ).

World Distribution: Mesoamerica and tropical South America.

Distinguished by floating leaves only $1-1.3 \times 0.7-1.2 \mathrm{~cm}$, covered with numerous papillae, hairs on the apex of papillae fused at their tips into a cage-like structure (informally called "egg-beater hairs"). The apex of the hairs, where they are attached, is dark brown. Additionally, there are hairs among the bases of the papillae and this character differs this species from $S$. auriculata Aubl., that has mostly adaxial lamina surface glabrous between papillae.

Prado et al. 1378 was misidentified as Salvinia minima Baker by Prado \& Moran (2009).

\section{SCHIZAEACEAE}

Characterized by each the sporangia borne in marginal fingerlike extensions of the lamina, each sporangium supplied by a single vein. Other characteristics are compact, horizontal or erect, pubescent rhizomes; leaves simple to several times dichotomous, the ultimate divisions foliaceous to scarcely laminar; petioles containing a single vascular bundle, glabrous, as long as or longer than the lamina, with an adaxial groove; veins free. Fertile segments (sporangiophores) pinnatifid, curved, borne at the tips of the laminae; sporangia erect, oblong, with an apical annulus, in 2 rows, spores monolete.

Pantropical, with a few extensions in the temperate zones; 2 genera, ca. 35 species. In Acre, 1 genus, 2 species.

Schizaea Sm., Mém. Acad. Roy. Sci. (Turin) 5: 419. Pl. 9, fig. 9. 1793, nom. cons.

Same characters as in the family.

1. Laminae with leaf tissue developed, narrowly obdeltate to broadly fan-shaped

S. elegans

1. Laminae with laminar tissue poorly developed (linear) or absent ...... S. stricta

Schizaea elegans (Vahl) Sw., J. Bot. (Schrader) 1800(2): 103. 1801. Acrostichum elegans Vahl, Symb. Bot. 2: 104, tab. 50. 1791.

Figures: 50I, J

Habit/Habitat: Herb; terrestrial in forest on terra firme.

Material examined: Cruzeiro do Sul, J. Prado et al. 1162 (SP, UFACPZ), J. Prado et al. 1175 (SP, UFACPZ), J. Prado et al. 1307 (SP, UFACPZ); Mâncio Lima, C.A. Cid et al. 10095 (NY), G.T. Prance et al. 12101 (NY), M. Silveira et al. 1259 (NY).

World Distribution: S Mexico, Greater Antilles, Mesoamerica, and tropical South America. 
One of the most beautiful fern species in Acre. It generally has fan-shaped laminae, these sometimes incised to various degrees. The laminae vary from fan-shaped and entire to several-times divided (furcate), sometimes with narrow segments.

Schizaea stricta Lellinger, Mem. New York Bot. Gard. 18(2): 8, fig. 1. 1969.

Habit/Habitat: Herb; terrestrial in Campinarana, on sandy soils.

Material examined: Mâncio Lima, A. Quinet et al. 1635 (NY, RB).

World Distribution: N South America.

Characterized by laminae 4- or 5 -forked and more than 30 segments/pinnae in each sporangiophore.

\section{TECTARIACEAE}

Characterized by rhizomes short-creeping or decumbent, less commonly erect or long-creeping; petioles with more than 4 vascular bundles, the adaxial ones enlarged, not jointed to the rhizome; laminae simple to 4-pinnate-pinnatifid, often pubescent with short $(<1 \mathrm{~mm})$, jointed hairs, especially on the adaxial surfaces of the axes; rachises and costae not grooved, or if slightly grooved then the grooves not decurrent into those of the next lowest order; veins free or anastomosing; sori typically round; indusia present or absent.

Tectariaceae is monophyletic (Zhang et al. 2016).

Pantropical and subtropical; 7 genera, ca. 250 species. In Acre, 3 genera, 5 species.

1. Rhizomes creeping; leaves distichous; veins free Triplophyllum

1. Rhizomes erect or decumbent; leaves polystichous; veins reticulate

2. Rachises not winged, adaxially puberulent; rhizomes and foliage when crushed without odor

Tectaria

2. Rachises winged, adaxially glabrous; rhizomes and foliage when crushed with odor of toasted almonds (cyanogenic)

Draconopteris

Draconopteris Li Bing Zhang \& Liang Zhang, Taxon 65(4): 732-733, fig. 1a-b, fig. 3a-d. 2016.

Characterized by erect to decumbent rhizomes; leaves arranged radially around the rhizomes, to $1.5 \mathrm{~m}$ long; sterile and fertile leaves monomorphic; laminae 1-pinnatifid; rachises winged; pinnae 3-4 pairs, entire except for a single basal basiscopic lobe on the basal pinnae; veins reticulate; sori round, numerous; indusia absent. The freshly cut rhizomes and petiole bases have a sweet smell of toasted almonds. Zhang et al. (2016) segregated this monotypic genus from Tectaria Cav.

Neotropical; 1 species.

Draconopteris draconoptera (D.C. Eaton) Li Bing Zhang \& Liang Zhang, Taxon 65(4): 732-733. 2016. Aspidium draconopterum D.C. Eaton, Mem. Amer. Acad. Arts, n.s. 8: 211. 1860.

Figure: 51A

Habit/Habitat: Herb; terrestrial, in primary forest, undulating terrain, in places dissected by many small streams.

Material examined: Brasiléia, D.C. Daly et al. 9882 (NY, UFACPZ), D.C. Daly et al. 11891(NY).

World Distribution: Mesoamerica and N South America to Bolivia.

Tectaria Cav., Anales Hist. Nat. 1(2): 115. 1799.

In Acre characterized by non-alate rachises, these and the costae puberulent adaxially, reticulate veins, round sori, and lack of toasted almond (cyanide) odor. Other characters of the genus include rhizomes erect or short-creeping, scaly; sterile and fertile leaves monomorphic, rarely

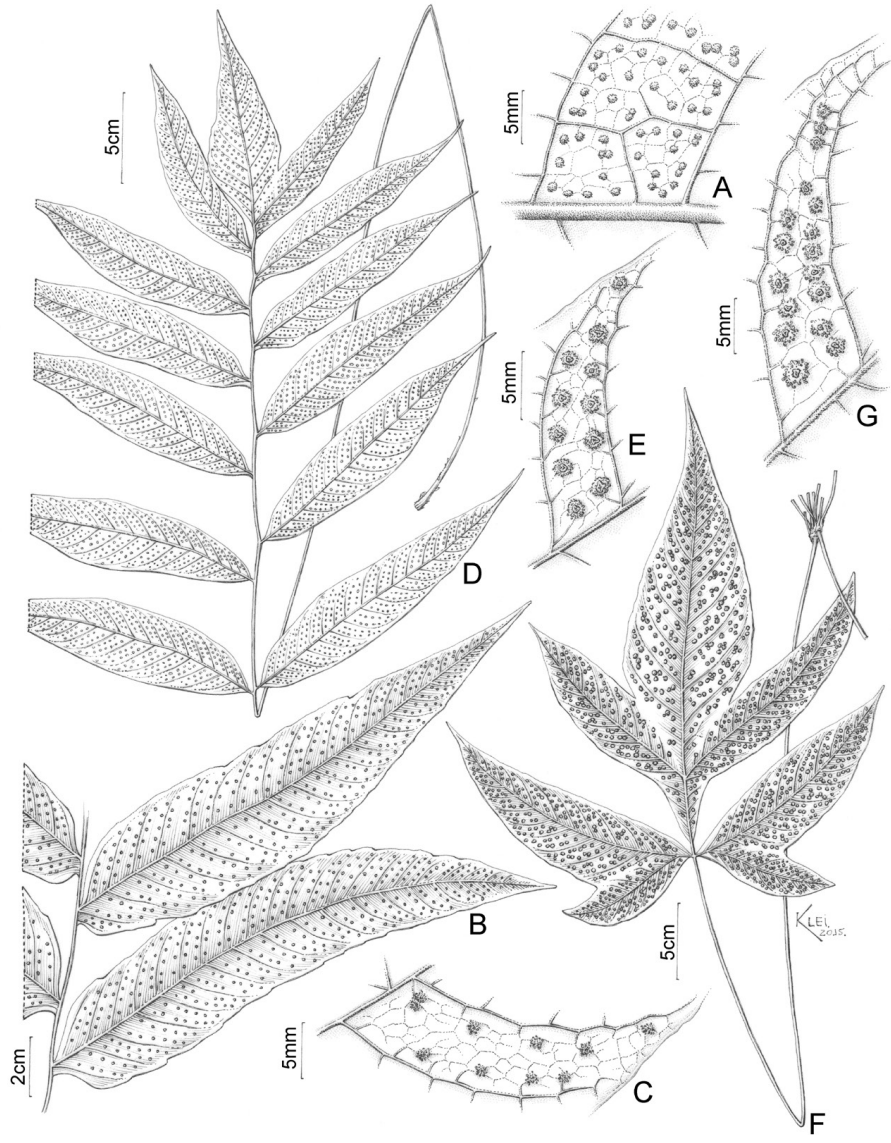

Figure 51. A. Draconopteris draconoptera (Daly et al. 11891, NY). A. Venation and sori. B, C. Tectaria incisa (Croat 86113, NY). B. Part of a fertile frond. C. Venation and sori. D, E. Tectaria aff. longipinnata (Prance et al. 7812A, NY). D. Fertile frond. E. Venation and sori. F, G. Tectaria trifoliata (Daly et al. 9883, NY). F. Habit. G. Venation and sori.

dimorphic; laminae simple and entire to 3-pinnate-pinnatifid; proximal pinnae often with a prolonged lobe or pinnule on the basal basiscopic side; rachises and costae rounded or shallowly grooved adaxially, the grooves not decurrent, puberulent, the hairs $0.1-0.2 \mathrm{~mm}$ long, reddish, pluricellular; veins reticulate, the areoles typically with included veinlets; indusia present, rarely absent.

Pantropical, with some extensions into the temperate zones; ca. 200 species, 3 in Acre.

1. Sori several and irregularly scattered between lateral secondary veins; pinnae $1(-2)$ pairs T. trifoliata

1. Sori biseriate between lateral secondary veins; pinnae more than 2 pairs

2. Pinnae 4-12 pairs; proximal pinnae stalked, the stalk 1-3 mm long. T. aff. longipinnata

2. Pinnae 3-5 pairs; proximal pinnae stalked, the stalk ca. $1 \mathrm{~mm}$ long T. incisa

Tectaria incisa Cav., Descr. P1. 249. 1802.

Figures: 51B, C

Habit/Habitat: Herb; terrestrial in forest on terra firme near stream margins, on sandy and clay soils.

Material examined: Cruzeiro do Sul, D.C. Daly et al. 7493 (NY, UFACPZ); Marechal Thaumaturgo, D.C. Daly et al. 10340 (NY), 
D.C. Daly et al. 10343 (NY); Quixadá, C.A. Cid \& A. Rosas Jr. 2952 (MG, NY); Rio Branco, C.A. Cid \& A. Rosas Jr. 2899 (NY); Santa Rosa, T.B. Croat 86113 (NY), D.C. Daly et al. 10052 (NY), D.C. Daly et al. 11335 (NY); Sena Madureira, G.T. Prance et al. 7667 (MG, NY); Tarauacá, D.C. Daly et al. 8617 (NY, UFACPZ), G.P. da Silva et al. 98 (NY); Xapuri, D.C. Daly et al. 7273 (NY, UFACPZ), C. Figueiredo 207 (NY, UFACPZ).

World Distribution: S Florida, Mexico, Antilles, Mesoamerica, and tropical and subtropical South America.

Characterized by sori in 2 series between the lateral secondary veins, and 3-5 pairs of pinnae, the proximal pair stalked (ca. $1 \mathrm{~mm}$ long) to the rachis.

Tectaria aff. longipinnata A. Rojas, Revista Biol. Trop. 49(2): 476-478, fig. 5. 2001.

Figures: 51D, E

Habit/Habitat: Herb; terrestrial on várzea forest.

Material examined: Mâncio Lima, G.T. Prance et al. 12047 (MG, NY), M. Silveira et al. 1229 (NY); Rio Branco, C.A. Cid \& A. Souza 2988 (NY); Sena Madureira, G.T. Prance et al. $7812 A$ (NY).

World Distribution: Mesoamerica and tropical South America.

Characterized by 4-12 pairs of elliptic pinnae, the proximal ones with a stalk 1-3 mm long. The specimens cited here might belong to Tectaria longipinnata described originally from Panama.

Tectaria trifoliata (L.) Cav., Descr. P1. 249. 1802. Polypodium trifoliatum L., Sp. Pl. 2: 1087. 1753.

Figures: 51F, G

Habit/Habitat: Herb; terrestrial in forest of terra firme, on undulating terrain, canopy discontinuous.

Material examined: Brasiléia, D.C. Daly et al. 1229 (NY, UFACPZ), D.C. Daly et al. 9883 (NY).

World Distribution: Antilles and N South America.

Characterized by sori irregularly scattered between two lateral secondary veins and pinnae 1(or 2) pairs.

Triplophyllum Holttum, Kew Bull. 41(2): 239. 1986.

Distinguished by creeping rhizomes, distichous leaves, typically tripartite laminae, free veins, and adaxially puberulent leaf axes. Other characters constant within the genus are long-petiolate, monomorphic sterile and fertile leaves; vascular bundles in petioles 4 or more; basal pinnae typically conspicuously larger than the suprabasal ones and wider on the basiscopic side; rachises and costae not grooved, usually puberulent abaxially provided with a few dark scales and usually also adaxially with reddish hairs, these 0.1-0.4 mm long, reddish, articulate, veins free; sori round; indusia present, circular to reniform, attached laterally (not peltate). The Neotropical species were revised by Prado \& Moran (2008), who recognized nine species in the Neotropics.

Neotropics, Africa, Madagascar; 20 species, 2 in Acre.

1. Pinna rachises glabrous or nearly so adaxially; indusia pubescent .... T. funestum

1. Pinna rachises puberulent and/or glandular; indusia glandular and pubescent

T. boliviense

Triplophyllum boliviense J. Prado \& R.C. Moran, Brittonia 60(2): 106, figs 5, 6. 2008.

Figures: $52 \mathrm{~A}-\mathrm{C}$

Habit/Habitat: Herb; terrestrial in forest on terra firme, undulating terrain. Material examined: Assis Brasil, D.C. Daly et al. 9883 (NY, UFACPZ); Brasiléia, D.C. Daly et al. 6738 (NY, UFACPZ); Bujari, D.C. Daly et al. 9856 (NY, UFACPZ).
World Distribution: N South America to Bolivia.

Triplophyllum funestum (Kunze) Holttum, Kew Bull. 41(2): 255. 1986. Aspidium funestum Kunze, Linnaea 9: 96. 1834.

Figures: 52D-F

Habit/Habitat: Herb; terrestrial in forest on terra firme, on clay soils. Material examined: Brasiléia, D.C. Daly et al. 7091 (NY); Cruzeiro do Sul, J. Prado et al. 1334 (SP, UFACPZ); Rodrigues Alves, J. Prado et al. 1247 (UFACPZ)

World Distribution: Antilles, Mesoamerica, and N South America to Bolivia.

Characterized by the adaxial surface of the pinna rachises glabrous to sparsely puberulent. The abaxial surface of the pinna rachises are evenly puberulent, the hairs $0.1-0.2 \mathrm{~mm}$ long. Highly variable in laminar cutting and size (Prado \& Moran 2008).

\section{THELYPTERIDACEAE}

Generally characterized by two vascular bundles in the petiole bases, 1-pinnate-pinnatifid laminae, acicular hairs, and round sori. Other characters include rhizomes creeping to erect, scaly, the scales non-clathrate; sterile and fertile leaves monomorphic or (less commonly) subdimorphic; laminae most commonly 1-pinnatifid-pinnatifid, rarely simple or 3- or 4-pinnate, typically lanceolate, elliptic or oblong, less often broadly deltate; rachises and costae usually grooved adaxially, if grooved, then the grooves not decurrent into those of the next lowest order; veins free or less commonly netted in a repetitive,

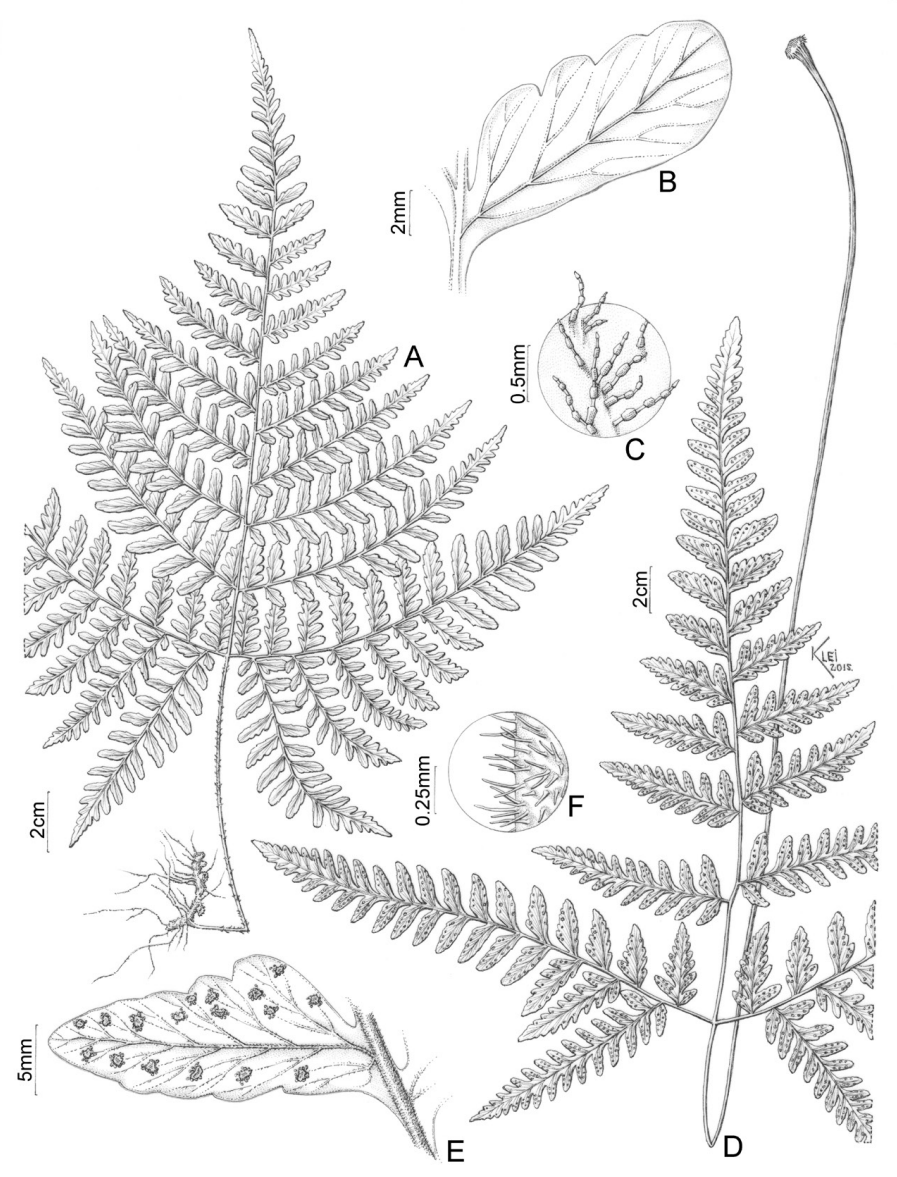

Figure 52. A-C. Triplophyllum boliviense (Daly et al. 6738, NY). A. Habit B. Sterile segment. C. Laminar hairs. D-F. Triplophyllum funestum (Prado et al. 1334, SP). D. Part of a fertile frond. E. Venation and sori. F. Hairs from rachis. 
regular way, typically ending the segment margins; sori round or rarely elongate; indusia present or absent; sporangial stalks 3-rowed.

We adopt here the most recent classification for the family published by Almeida et al. (2016).

Cosmopolitan; 30 genera, 1,034 species. In Acre, 6 genera, 19 species.

1. Foliar hairs forked or stellate

Goniopteris

1. Foliar hairs unbranched

2. Veins netted regularly in pairs, with the transverse veins producing excurrent veinlets that run toward the margin or to the next areole; indusia absent

Meniscium

2. Veins free or with one or two pairs anastomosing below the sinus; indusia present or absent

3. Lamina with several pairs of reduced proximal pinnae forming auricles Amauropelta

3. Lamina without reduced pinnae or with slightly reduced non-auriculate pinnae

4. Aerophores present at pinna bases abaxially ....... Steiropteris

4. Aerophores absent at pinna bases abaxially

5. Proximal veins from adjacent segments united below the sinus with an excurrent vein to sinus Christella

5. Proximal veins from adjacent segments connivent at or running to sinus

6. Proximal pinnae with basal auricles

Christella

6. Proximal pinnae without basal auricles

Amblovenatum

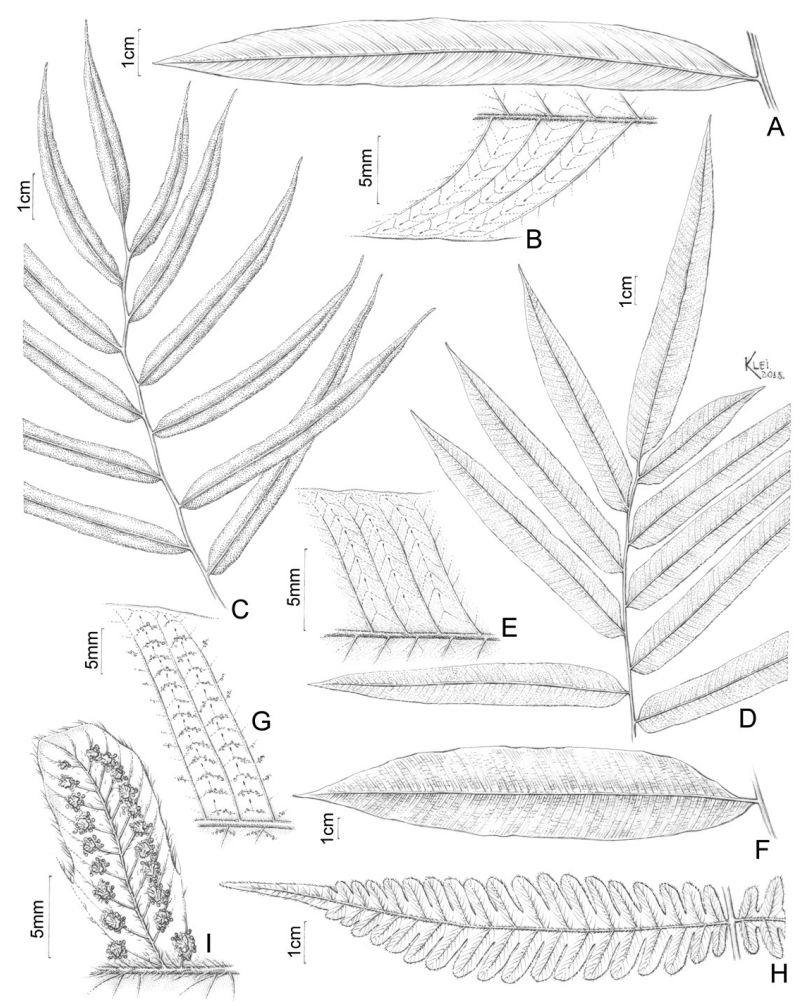

Figure 53. A-C. Meniscium angustifolium (Daly et al. 8764, NY). A. Pinna. B. Venation. C. Part of a fertile frond. D, E. Meniscium arborescens (Prado et al. 1298 , SP). D. Part of a sterile frond. E. Fertile pinna. F, G. Meniscium chrysodioides var. goyazense (Croat \& Rosas 62670, NY). F. Sterile pinna. G. Fertile pinna. H, I. Goniopteris biformata (Croat et al. 85199, NY). H. Sterile pinna. I. Fertile pinna.
Amauropelta Kunze, Farrnkräuter 1: 86. 1843.

Characterized by laminar bases with four or more pairs of pinnae gradually to abruptly reduced, basalmost auriculate. Veins from adjacent segments usually meeting the margin the above the sinus.

Pantropical; 215 species, 1 in Acre.

Amauropelta opposita (Vahl) Pic. Serm., Webbia 31(1): 251. 1977. Polypodium oppositum Vahl, Eclog. Amer. 3: 53. 1807.

Figures: 55E, F

Habit/Habitat: Herb; terrestrial, riverside vegetation.

Material examined: Assis Brasil, D.C. Daly et al. 9644 (NY, UFACPZ), D.C. Daly et al. 9653 (NY, UFACPZ).

World Distribution: Antilles, Mesoamerica, and tropical South America.

Characterized by laminar tissue abaxially with acicular or crispate hairs, yellowish to orangish sessile resinous glands on the veins and the laminar tissue, segment margins often revolute.

Amblovenatum J.P. Roux, Strelitzia 23: 200-201. 2009.

In Acre characterized by the presence of sulfur-yellow, sphaerical, sessile glands on the veins abaxially. Also distinctive by laminae 1-pinnate, abruptly reduced distally and ending in a pinnatifid apex, segments falcate and the proximal ones of each pinna reduced, sori on the segment apices, indusia with glands and hairs.

Tropics and subtropics of the Old World, naturalized in the Neotropics; probably fewer than 10 (Alan R. Smith (UC), personal communication) species, 1 in Acre.

Amblovenatum opulentum (Kaulf.) J.P. Roux, Strelitzia 23: 201. 2009. Aspidium opulentum Kaulf., Enum. Filic. 238. 1824.

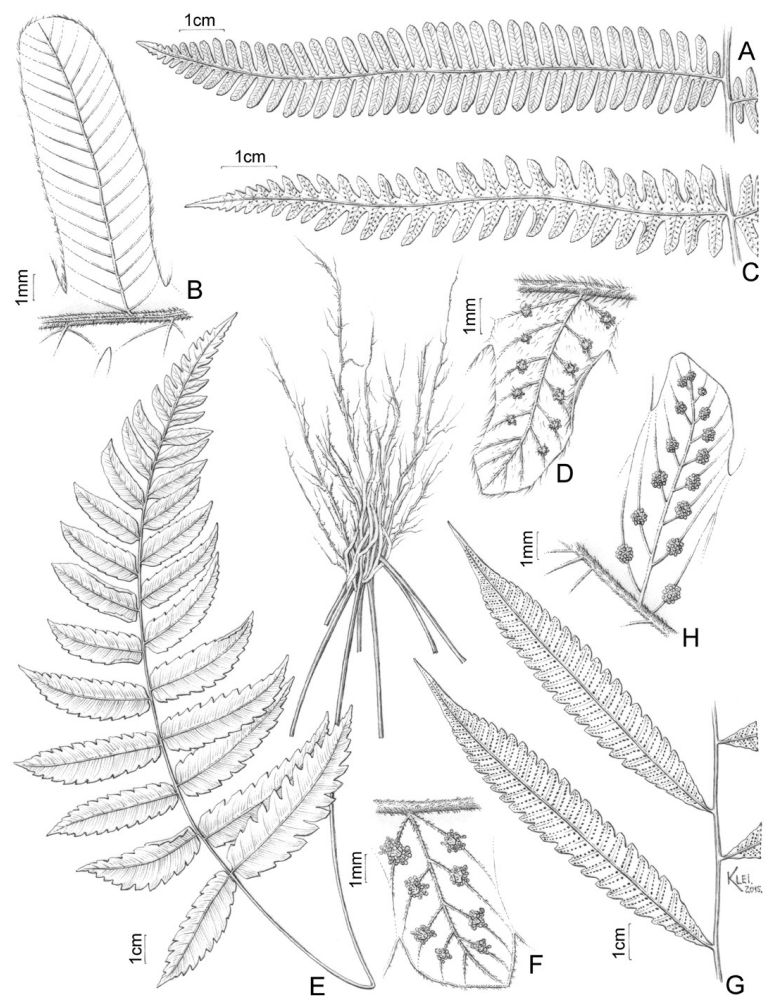

Figure 54. A, B. Steiropteris aff. decussata (Prado et al. 1370, SP). A. Sterile pinna. B. Sterile pinna. C, D. Christella hispidula (Croat et al. 86012, NY). C. Fertile pinna. D. Fertile pinna. E, F. Goniopteris abrupta (Daly et al. 11780, NY). E. Habit. F. Fertile pinna. G, H. Goniopteris juruensis (Maas et al. P12918, NY). G. Part of a fertile frond. H. Fertile pinna. 
Figures: 55G, H

Habit/Habitat: Herb; terrestrial in open forest with palms and weak presence of Guadua sarcocarpa, canopy ca. $25 \mathrm{~m}$, deeply dissected terrain. Sandy-clay soil. A common weedy species in Acre and other parts of the Neotropics.

Material examined: Cruzeiro do Sul, D.C. Daly et al. 11858 (NY), L.R. Marinho 204 (NY), P.J.M. Maas et al. P13304 (NY), J. Prado et al. 1333 (SP, UFACPZ); G.T. Prance et al. 12428 (MG, NY); Mâncio Lima, J. Prado et al. 1144 (SP, UFACPZ); Manoel Urbano, D.C. Daly et al. 10458 (NY), D.C. Daly et al. 11498 (NY); Marechal Thaumaturgo, D.C. Daly et al. 10366 (NY); Porto Acre, C. Figueiredo \& I. Riveiro 751 (NY); Santa Rosa, D.C. Daly et al. 10158 (NY), D.C. Daly et al. 11098 (NY), D.C. Daly et al. 11327 (NY); Sena Madureira, L. de Lima et al. 553 (NY, UFACPZ), G.T. Prance et al. 7662 (NY); Xapuri, L.G. Lohmann \& E.C. de Oliveira 598 (NY).

World Distribution: Antilles, Mesoamerica, and N South America to Bolivia. Native to Asia and Africa.

Christella H. Lév., Fl. Kouy-Tchéou 472. 1915.

Characterized in Acre by long-creeping to erect rhizomes with conspicuous scales, 0 to 4 proximal pinna pairs slightly to greatly reduced but not forming auricles at lamina base, aerophores absent, and persistent indusia.

Paleotropics; 70 species, 3 in Acre.
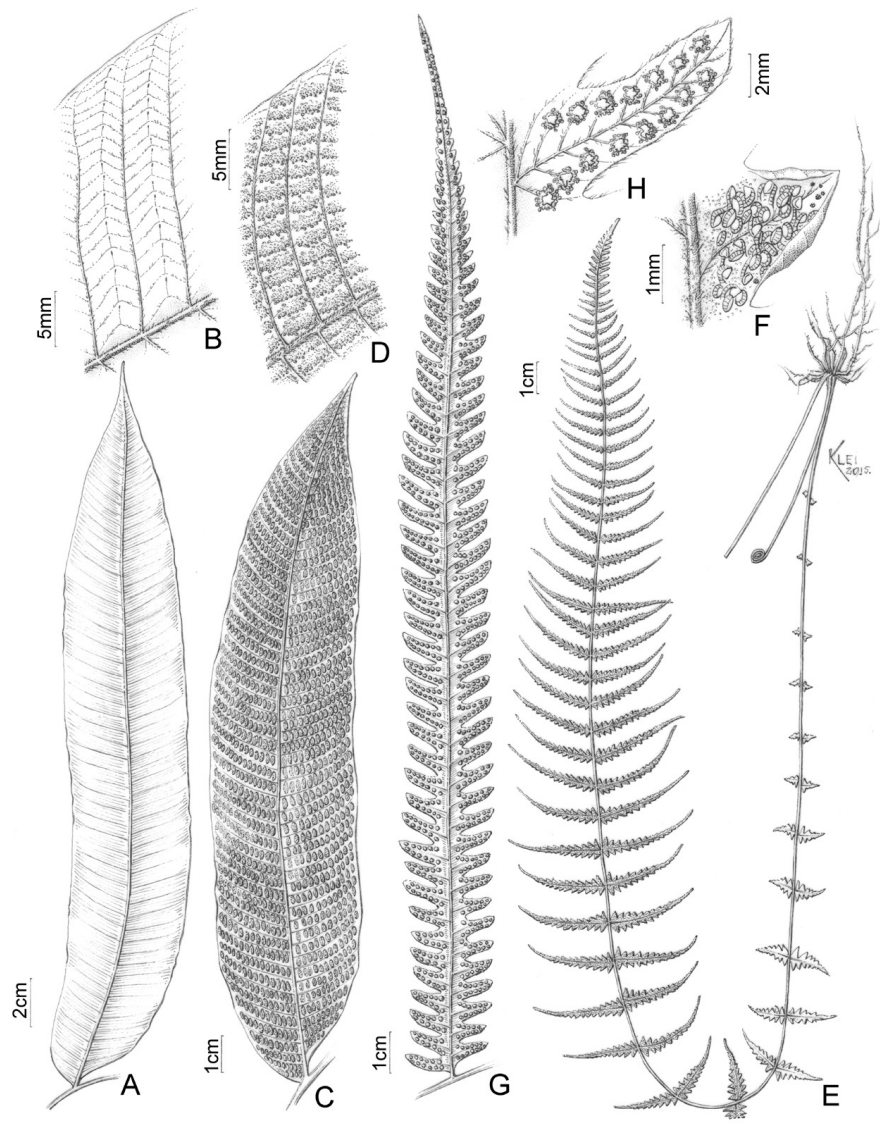

Figure 55. A, B. Meniscium macrophyllum (Prado et al. 1337, SP). A. Sterile pinna. B. Fertile pinna. C, D. Meniscium membranaceum (Silveira et al. 1249, NY) C. Fertile pinna. D. Fertile pinna. E, F. Amauropelta opposita (Daly et al. 9644, NY). E. Habit. F. Fertile pinna. G, H. Amblovenatum opulentum (Prado et al. 1144, SP). G. Fertile pinna. H. Fertile pinna.
1. Rhizomes long-creeping C. grandis var. kunzeana

1. Rhizomes suberect to erect

2. Proximal pair of segments not elongate, oblique to the rachis ..... C. hispidula

2. Proximal pair of segments elongate, parallel, close to the rachis C.patens

Christella grandis A.R. Sm. var. kunzeana (Hook.) A.R. Sm., Phytotaxa (submitted). Nephrodium kunzeanum Hook.

Habit/Habitat: Herb; terrestrial on banks of rivers.

Material examined: Marechal Thaumaturgo, Daly et al. 10197 (NY) World Distribution: Ecuador to Bolivia, and Brazil.

Characterized by long-creeping rhizomes, abaxially moderately to densely puberulent rachises, the hairs $0.1-0.2 \mathrm{~mm}$ long, costae and veins puberulent, the hairs $0.1-0.2 \mathrm{~mm}$ long, laminar tissue glabrous, adaxially glabrous except for costal hairs; indusia puberulent, the hairs $0.1 \mathrm{~mm}$ long.

Christella hispidula (Decne.) Holttum, Kew Bull. 31(2): 312.1976. Aspidium hispidulum Decne., Nouv. Ann. Mus. Hist. Nat. 3: 346. 1834.

Figures: $54 \mathrm{C}, \mathrm{D}$

Habit/Habitat: Herb.; terrestrial in forest on terra firme.

Material examined: Porto Acre, T.B. Croat et al. 86012 (NY).

World Distribution: United States, Mesoamerica, Antilles, and South America; tropical and subtropical Africa and Asia.

Characterized by proximal pair of pinnae reduced and oblique to the rachis. Additionally the indument comprises acicular hairs more than $0.3 \mathrm{~mm}$ long, with some to $0.5 \mathrm{~mm}$ long.

Christella patens (Sw.) Holttum, Webbia 30(1): 193. 1976. Polypodium patens Sw., Prodr. 133. 1788.

Figures: 56A, B

Habit/Habitat: Herb; terrestrial in forest on steep slopes.

Material examined: Assis Brasil, D.C. Daly et al. 9635 (NY); Porto Valter, D.C. Daly et al. 11780 (NY).

World Distribution: Mexico, Antilles, Mesoamerica, and tropical South America.

Characterized by proximal pair of segments elongate, parallel and close to the rachis. At least at the middle of the leaf, the elongated segments overlap each other.

Goniopteris C. Pres1, Tent. Pterid. 181-183, tab. 7, fig. 9-11. 1836.

Characterized by forked or stellate hairs on the rachises costae, and rhizome scales (magnification needed). The main thelypteroid genus in the lowland tropics, especially Amazonia. Its species hybridize, but this has been poorly studied.

Neotropical; 120 species, 6 in Acre.

1. Lamina apices pinnatifid

2. Laminar tissue abaxially glabrous G. abrupta

2. Laminar tissue abaxially puberulent, the hairs scattered, acicular, $0.1-0.2 \mathrm{~mm}$ long

G. jamesonii

1. Lamina apices conform (i.e., resembling a lateral pinna) or subconform

3. Laminar tissue abaxially stellate-pubescent G. schunkei

3. Laminar tissue abaxially glabrous or pubescent with acicular hairs 4. Laminar tissue abaxially pubescent G. biformata

4. Laminar tissue abaxially glabrous 
5. Pinnae incised $1 / 3-2 / 5$ the distance to costae; pinnae $9-13 \times 1.5-2 \mathrm{~cm}$ G. juruensis

5. Pinnae incised $1 / 2$ or more the distance to costae; pinnae $14-16 \times 3-4 \mathrm{~cm}$ G. tristis

Goniopteris abrupta (Desv.) A.R. Sm., PhytoKeys 57: 36. 2015. Polypodium abruptum Desv., Mém. Soc. Linn. Paris 6: 239. 1827.

Figures: 54E, F

Habit/Habitat: Herb; terrestrial in forest on terra firme.

Material examined: Feijó, M. Alves et al. 2539 (NY); Marechal Thaumaturgo, Daly et al. 10251 (NY, RB); Porto Valter, D.C. Daly et al. $11780(\mathrm{NY})$.

World Distribution: Antilles and N South America to Bolivia.

Characterized by pinnatifid lamina apices, buds present on the base of the distal pinnae, medial pair of pinnae with truncate base, pair of proximal pinnae distinctly cuneate at base, indusia and stalk of the sporangia setulose. Indument of the costa abaxially puberulent, the hairs acicular, $0.1-0.2 \mathrm{~mm}$ long. Laminar tissue abaxially glabrous.

Goniopteris biformata (Rosenst.) Salino \& T.E. Almeida, PhytoKeys 57: 37. 2015. Dryopteris biformata Rosenst., Repert. Spec. Nov. Regni Veg. 7: 300-301. 1909.

Figures: $53 \mathrm{H}, \mathrm{I}$

Habit/Habitat: Herb; terrestrial in forest on terra firme.

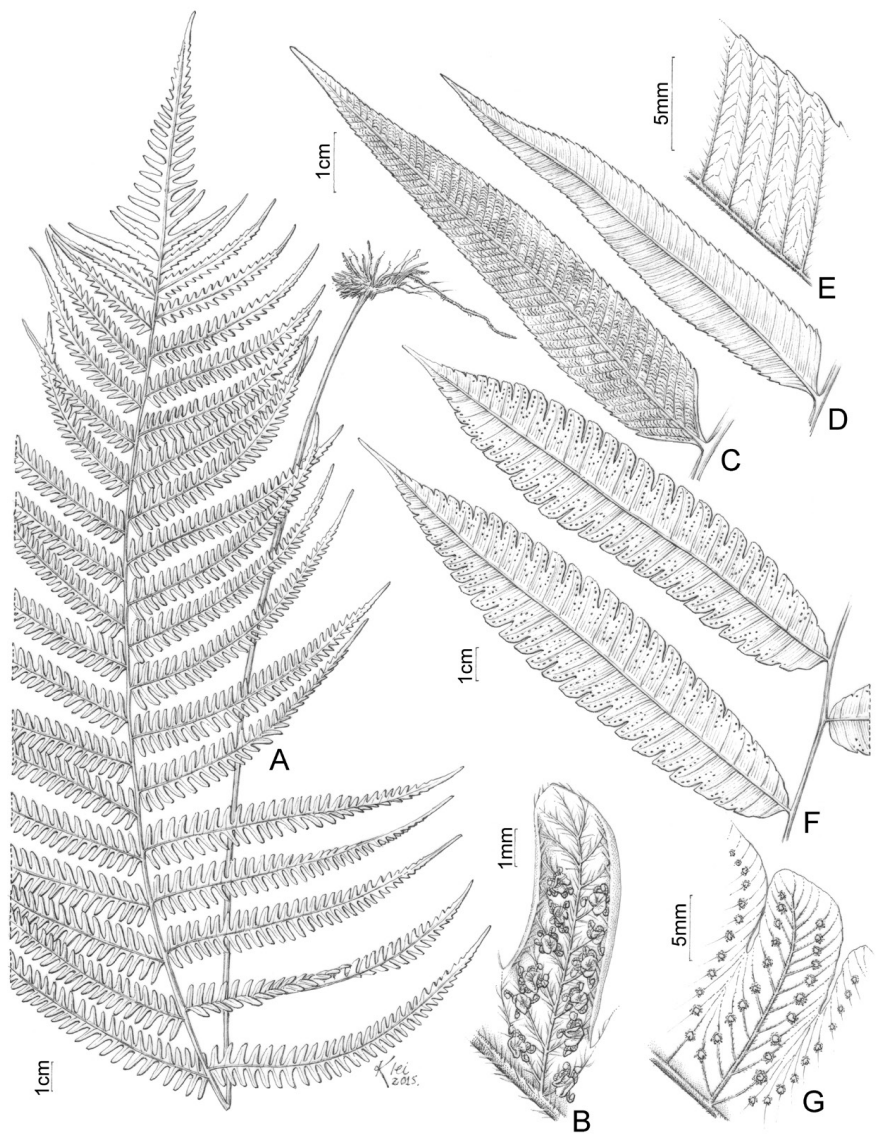

Figure 56. A, B. Christella patens (Daly et al. 9635, NY). A. Fertile frond. B. Fertile segment. C-E. Meniscium serratum (Lowrie \& Nelson 695, NY). C. Fertile pinna. D. Sterile pinna. E. Veins. F, G. Goniopteris juruenseis (Prado et al. 1376, SP). F. Fertile pinnae. G. Fertile pinna.
Material examined: Porto Walter, T.B. Croat et al. 85199 (NY).

World Distribution: N South America.

Characterized by buds at the base of the distal pinnae, laminae ending in conform or subconform terminal pinna, and indusia and sporangial stalks setulose. Other characters constant in the species include costae abaxially pubescent, the hairs acicular, 0.4-1 $\mathrm{mm}$ long, and laminar tissue abaxially with mostly acicular hairs.

Goniopteris jamesonii (Hook.) Salino \& T.E. Almeida, PhytoKeys 57: 39. 2015. Nephrodium jamesonii Hook., Sp. Fil. 4: 66. 1862.

Habit/Habitat: Herb; terrestrial in forest on terra firme, on steep slopes. Material examined: Cruzeiro do Sul, D.C. Daly et al. 11698 (NY).

World Distribution: N South America to Bolivia, and southern Brazil.

Characterized by pinnatifid lamina apices, basally truncate medial pinnae, 2 or 3 proximal pinna pairs deflexed and slightly shortened. Indument of the costae abaxially pubescent, the hairs of two sizes, short ones (ca. $0.2 \mathrm{~mm}$ ) mixed with longer ones $(0.5-1.0 \mathrm{~mm})$. Laminar tissue abaxially puberulent, the hairs acicular, $0.1-0.2 \mathrm{~mm}$ long, adaxially with appressed hairs ca. $0.2 \mathrm{~mm}$ long between the veins.

Goniopteris juruensis (C. Chr.) Brade, Bradea 1(22): 216.1972. Dryopteris juruensis C. Chr., Kongel. Danske Vidensk. Selsk. Skr., Naturvidensk. Math. Afd., ser. 7, 10(2): 256, fig. 43d. 1913.

Figures: 54G, H, 56F, G

Habit/Habitat: Herb; terrestrial in forest on terra firme.

Material examined: Cruzeiro do Sul, P.J.M. Maas et al. P12918 (NY); J. Prado et al. 1376 (SP, UFACPZ); Manoel Urbano, D. C. Daly et al. 11391 (NY); Rio Branco, C.A. Cid \& A. Rosas Jr. 2950 (NY); Sena Madureira, G.T. Prance et al. 7812 (NY), G.T. Prance et al. 7853 (NY).

World Distribution: N South America to Bolivia, and southern Brazil.

Characterized by laminae ending in conform terminal pinna, pinnae with cuneate bases, buds present at the base of the distal pinnae, indusia small, glabrous or setulose, or apparently indusia absent, and sporangia glabrous. Costa abaxially nearly glabrous, but sparse hairs present, the hairs acicular, ca. $0.1 \mathrm{~mm}$ long. Laminar tissue abaxially glabrous.

Goniopteris schunkei (A.R. Sm.) Salino \& T.E. Almeida, PhytoKeys 57: 43. 2015. Thelypteris schunkei A.R. Sm., Fieldiana, Bot., n.s. 29: 63. 1992.

Habit/Habitat: Herb; terrestrial, terra firme forests.

Material examined: Manuel Urbano, Medeiros 758 et al. (NY).

World Distribution: Peru, Bolivia, western Brazil.

Characterized by laminae ending in a conform terminal pinna, pinnae truncate basally, buds absent, veins anastomosing, indusia with dense indument of stellate hairs, sporangia with stellate hairs. Costae and laminar tissue abaxially with stellate hairs.

Goniopteris tristis (Kunze) Brade, Bradea 1(22): 217. 1972. Polypodium triste Kunze, Linnaea 9: 47. 1834.

Habit/Habitat: Herb; terrestrial in forest of terra firme, on clay soils.

Material examined: Mâncio Lima, J. Prado et al. 1138 (SP, UFACPZ); Porto Valter, D.C. Daly et al. 11767 (NY).

World Distribution: Mesoamerica and tropical South America.

Characterized by laminae ending in a conform terminal pinna, pinnae with cuneate bases, buds sometimes present at the base of the distal pinnae, indusia absent, and sporangia glabrous. Costae abaxially glabrous or with sparse acicular, forked, or stellate hairs, ca. $0.1 \mathrm{~mm}$ long. Laminar tissue abaxially glabrous.

Meniscium Schreb., Gen. P1. 2: 757. 1791.

Characterized by laminae 1-pinnate, rarely entire; pinnae entire or serrate, the basal ones the largest or nearly so; aerophores absent; veins netted regularly in pairs, with the transverse veins producing excurrent veinlets that run toward the margin or next areole, the areoles 4-25(-35) between the costa and margin; sori on the transverse veins, elongate (not round); indusia absent; sporangia glabrous or setose. 
Neotropical; 27 species, 7 species in Acre.

1. Pinnae conspicuously serrate or uncinate M. serratum

1. Pinnae entire, subentire, crenate or crenulate

2. Distal pinnae gradually reduced M. angustifolium

2. Distal pinnae not reduced or only slightly so

3. Medial pinnae $30-35 \times 5-6 \mathrm{~cm}$ M. macrophyllum

3. Medial pinnae $10-24 \times 2-6 \mathrm{~cm}$

4. Medial pinnae elliptic M. arcanum

4. Medial pinnae oblong or lanceolate

5. Rachises and costae abaxially with hairs falcate to crispate M. angustifolium

5. Rachises and costae with hairs acicular, erect

6. Pinnae $1.5-2 \mathrm{~cm}$ wide

M. arborescens

6. Pinnae 3-6 cm wide .... M. chrysodioides var. goyazense

\section{Meniscium angustifolium Willd., Sp. Pl. 5: 133. 1810.}

Figures: $53 \mathrm{~A}-\mathrm{C}$

Habit/Habitat: Herb; terrestrial in forest on terra firme, on sandy soil.

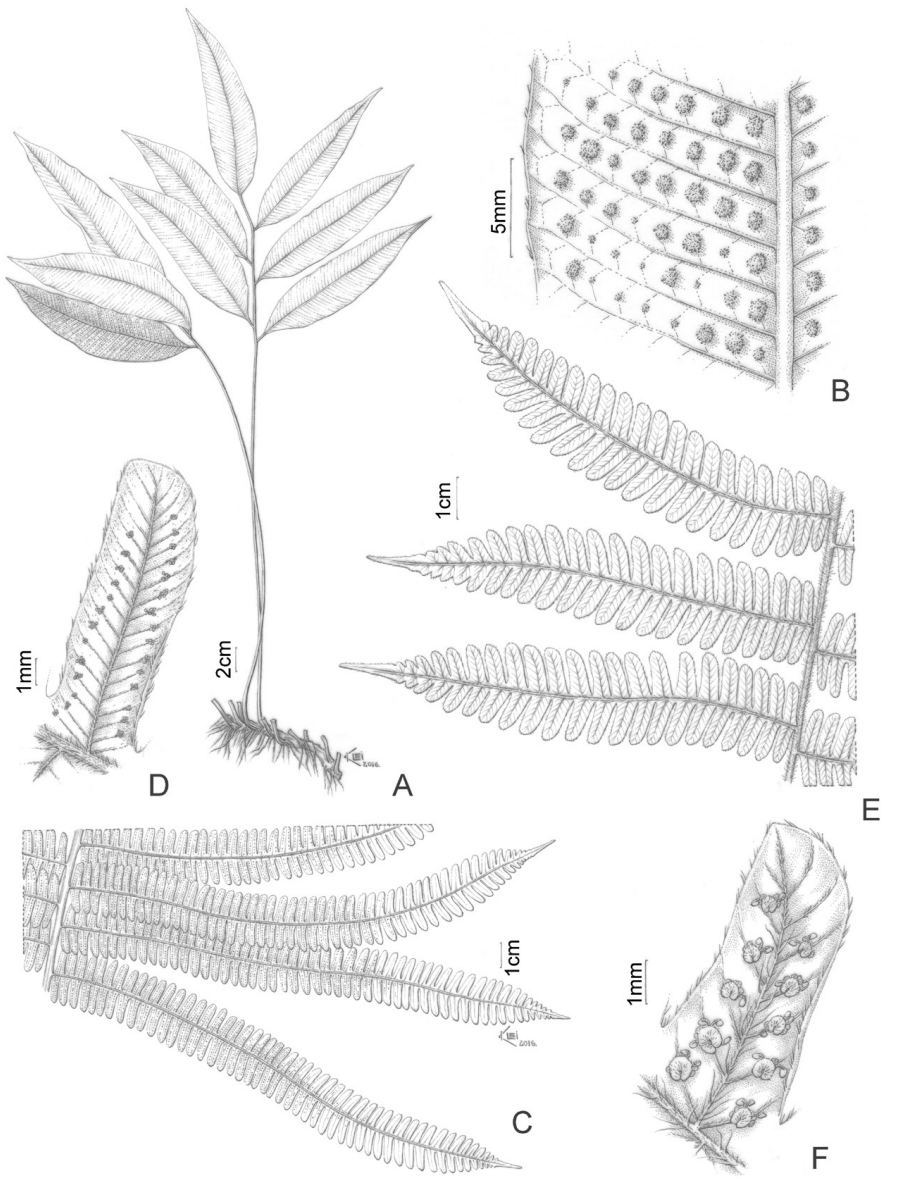

Figure 57. A, B. Meniscium arcanum (Salino \& Almeida 15026, BHCB). A. Habit B. Fertile pinna. C, D. Steiropteris sp. 1 (Salino \& Almeida 15024, BHCB). C. Sterile pinna. D. Fertile pinna. E, F. Steiropteris leprieurii var. incana (Salino \& Almeida 15014, BHCB). E. Sterile pinna. F. Fertile pinna.
Material examined: Mâncio Lima, D.C. Daly et al. 8921 (NY, UFACPZ), M. Silveira et al. 1292 (NY), M. Silveira et al. 1299 (NY); Marechal Thaumaturgo, D.C. Daly et al. 10196 (NY); Tarauacá, D.C. Daly et al. 8764 (NY, UFACPZ).

World Distribution: Mexico, Antilles, Mesoamerica, and tropical South America.

Characterized by pubescent rachises and costae, the hairs falcate or crispate, laminar tissue and veins adaxially glabrous, costa adaxially pubescent, sporangia glabrous. Distal pinnae gradually reduced. Margins of the pinnae entire to crenate.

Meniscium arborescens Humb. \& Bonpl. ex Willd., Sp. Pl. 5: 133. 1810

Figures: 53D, E

Habit/Habitat: Herb; terrestrial in forest on terra firme near stream margins.

Material examined: Cruzeiro do Sul, J. Prado et al. 1298 (SP, UFACPZ).

World Distribution: Mesoamerica and tropical South America.

Characterized by pubescent laminae with the distal pinnae not reduced, pinnae subentire to crenate, and pinna rachises pubescent on the adaxial surface only.

Meniscium arcanum (Maxon \& C.V. Morton) Pic. Serm., Webbia 23(1): 180. 1968. Dryopteris arcana Maxon \& C.V. Morton, Bull. Torrey Bot. Club 65: 352, tab. 11. 1938.

Figures: 57A, B

Habit/Habitat: Herb; terrestrial in Forest of terra firme near stream.

Material examined: Mâncio Lima, A. Salino \& T.E. Almeida 15026 (BHCB).

World Distribution: N South America to Bolivia.

Characterized by orangish cylindrical glands on the receptacle of the sporangia. Other characters include glabrous laminae adaxially, glabrous rachises (both surfaces), distal pinnae not reduced, and pinnae entire to crenate.

Meniscium chrysodioides Fée var. goyazense (Maxon \& C.V. Morton) J. Prado, R.Y. Hirai \& R.C. Moran, comb. nov. Dryopteris chrysodioides (Fée) Maxon \& C.V. Morton var. goyazensis Maxon \& C.V. Morton, Bull. Torrey Bot. Club. 65: 374. 1938.

Figures: 53F, G

Habit/Habitat: Herb; terrestrial in forest on terra firme near stream margins.

Material examined: Cruzeiro do Sul, T.B. Croat \& A. Rosas Jr. 62670 (NY, UFACPZ).

World Distribution: N South America to Bolivia.

Characterized by hairs ca. $0.2 \mathrm{~mm}$ long on the sporangial stalks, sparsely pubescent rachises, the hairs acicular, costae, veins, and laminar tissue abaxially pubescent, the hairs acicular, erect, adaxially almost glabrous, except for costal hairs. Other characters are distal pinnae slightly reduced, and pinna margins subentire to crenate.

Meniscium macrophyllum Kunze, Flora 22(1): Beibl. 44. 1838.

Figures: 55A, B

Habit/Habitat: Herb; terrestrial in forest on terra firme.

Material examined: Cruzeiro do Sul, J. Prado et al. 1337 (SP, UFACPZ)

World Distribution: N South America and southern Brazil.

Characterized by large entire pinnae, generally $30-35 \times 5-6 \mathrm{~cm}$. Also, the laminar tissue is glabrous on both surfaces, but the rachises, costae, and veins abaxially are pubescent with appressed, sparse hairs.

Meniscium membranaceum (Mett.) Pic. Serm., Webbia 23: 180. 1968. Phegopteris membranacea Mett., Fil. Lechl. 2: 22. 1859. 
Figures: $55 \mathrm{C}, \mathrm{D}$

Habit/Habitat: Herb; terrestrial in forest on terra firme.

Material examined: Mâncio Lima, M. Silveira et al. 1249 (NY).

World Distribution: N South America to Bolivia.

Characterized by rachises densely pubescent, laminar tissue, costae and veins abaxially moderately to densely pubescent, the hairs appressed, adaxially almost glabrous, except for costal hairs and a few hairs on veins. Sporangia glabrous. Distal pinnae slightly reduced. Buds present in axils of proximal pinnae. Margins of pinnae subentire to crenulate.

Meniscium serratum Cav., Descr. P1. 548. 1802.

Figures: $56 \mathrm{C}-\mathrm{E}$

Habit/Habitat: Herb; terrestrial in primary moist forest on terra firme.

Material examined: Brasiléia, S.R. Lowrie \& B. Nelson 695 (MG, NY); Cruzeiro do Sul, J. Prado et al. 1164 (SP, UFACPZ); Rio Branco, D.C. Daly et al. 6882 (NY, UFACPZ), E. Forero et al. 6377 (MG, NY).

World Distribution: S Florida, Antilles, Mesoamerica, and tropical and subtropical South America.

The only species of Meniscium with conspicuously serrate or uncinate-serrate pinnae, and distal pinnae gradually reduced. Also distinctive by laminar tissue, rachises, costae, and veins abaxially puberulent, laminar tissue and veins adaxially glabrous. Sporangia glabrous.

Steiropteris (C. Chr.) Pic. Serm., Webbia 28: 449. 1973. Dryopteris subg. Steiropteris C. Chr., Biol. Arb. Til. Eug. Warming 81. 1911.

Usually characterized by conspicuous peglike or scalelike aerophores at pinna bases where they join the rachis, and a cartilaginous keel or minutely pubescent false veins running to the base of sinuses (this absent in some species).

Neotropical; 22 species, 3 in Acre.

1. Sinus keels prominent (a cartilaginous raised false veinlet); aerophores peglike at bases of pinnae S. leprieurii var. incana

1. Sinus keels absent; aerophores scalelike at bases of pinnae

2. Rachises puberulent, the hairs ca. $0.1 \mathrm{~mm}$ long; costae abaxially with few appressed scales, densely hairy, the hairs ca. $0.1 \mathrm{~mm}$ long intermixed with hairs $0.5 \mathrm{~mm}$ long, and round, sessile, orangish to reddish glands

Steiropteris sp. 1

2. Rachises densely glandular, the glands stipitate, ca. $0.05 \mathrm{~mm}$ long; costae abaxially lacking scales, densely glandular, with glands similar to those of the rachises, also with sparse acicular hairs, ca. $0.1 \mathrm{~mm}$ long Steiropteris aff. decussata

Steiropteris aff. decussata (L.) A.R. Sm., PhytoKeys 57: 45. 2015. Polypodium decussatum L., 2: 1093. 1753.

Figures: 54A, B

Habit/Habitat: Herb; terrestrial in forest on terra firme, on steep slopes. Material examined: Rodrigues Alves, J. Prado et al. 1370 (SP, UFACPZ). World Distribution: Brazil (Acre).

Characterized by rachises densely glandular, the glands stipitate, ca. $0.05 \mathrm{~mm}$ long; costae abaxially densely glandular, the glands similar to those of rachises plus sparse acicular hairs, the hairs ca. $0.1 \mathrm{~mm}$ long, laminar tissue abaxially glabrous or rarely with a very few sparse acicular hairs, the hairs ca. $0.1 \mathrm{~mm}$ long, and sparse sessile, reddish to orangish, round glands. Aerophores scalelike at bases of pinnae. Sinus keels absent. Petioles with linear, straight or tortuous aerophores.

This gathering was previously identified as Thelypteris decussata var. decussata by Prado \& Moran (2009). But, var. decussata differs by the following characters: Rachises pubescent or glabrescent abaxially, hairs mostly $0.1-0.25 \mathrm{~mm}$ (vs. rachises densely glandular, the glands stipitate, ca.
$0.05 \mathrm{~mm}$ in Steiropteris aff. decussata), costae abaxially of moderately dense to dense, spreading, non-septate hairs mostly less than $0.5 \mathrm{~mm}$ (vs. costae abaxially lacking scales, densely glandular, the glands similar to those of rachises plus sparse acicular hairs, the hairs ca. $0.1 \mathrm{~mm}$ long). As we have only one specimen of this species, we refrain from describing it as new.

Steiropteris leprieurii (Hook.) Pic. Serm. var. incana (Christ) A.R. Sm., PhytoKeys 57: 46. 2015. Aspidium incanum Christ, Hedwigia 44: 367. 1905.

Figures: 57E, F

Habit/Habitat: Herb; terrestrial in forest on terra firme, near stream margins.

Material examined: Mâncio Lima, A. Salino \& T.E. Almeida 15014 (BCHB).

World Distribution: N South America.

This variety is characterized by the presence of aerophores on the base of the pinnae, prominent sinus keels, indusia with acicular hairs, hairs on the costae and veins abaxially of fertile leaves dense, $0.2-2 \mathrm{~mm}$ long, septate. Aerophores peglike at bases of pinnae. Sinus keels present (a cartilaginous raised false veinlet).

The specimen Salino \& Almeida 15014 was cited as Thelypteris (Steiropteris) valdepilosa (Baker) C.F. Reed by Almeida \& Salino (2015). However, that species differs in having orangish glands on the sporangial receptacles and fertile leaves puberulent on the costae and veins abaxially, the hairs $0.1-0.3 \mathrm{~mm}$ long. Additionally, this species has a few linear appressed scales on the costae abaxially (vs. scales absent on costae in var. incana).

Steiropteris sp. 1

Figures: 57C, D

Habit/Habitat: Herb; terrestrial in terra firme forests.

Material examined: Mâncio Lima, A. Salino \& T.E. Almeida 15024 (BHCB). World Distribution: Brazil (Acre).

Characterized by puberulent rachises, the hairs ca. $0.1 \mathrm{~mm}$ long; costae abaxially with a few appressed scales, hairs ca. $0.1 \mathrm{~mm}$ long intermixed with hairs $0.5 \mathrm{~mm}$ long, and round, sessile, orangish to reddish glands; laminar tissue abaxially densely glandular, the glands round, sessile, orangish to reddish, also with whitish acicular hairs ca. $0.1 \mathrm{~mm}$ long. Aerophores scalelike at bases of pinnae. Sinus keels absent (often minutely pubescent pseudovein). Petiole with aerophores becoming stout, winged spines.

Salino \& Almeida 15024 (BHCB) was identified by Almeida \& Salino (2015) as Thelypteris comosa (C.V. Morton) C.V. Morton and cited as a new record for the Acre. It does not, however, agree with the circumscription of that species given by Smith $(1980,1992)$. Steiropteris comosa differs in rachises pubescent abaxially, hairs $0.1-0.2 \mathrm{~mm}$ and a few to $2 \mathrm{~mm}$ (vs. puberulent, the hairs ca. $0.1 \mathrm{~mm}$ in Steiropteris sp.1), indument on costae abaxially of moderately dense to dense, spreading, sometimes septate hairs mostly 1-2 mm (vs. costae abaxially with few appressed scales, densely hairy, the hairs ca. $0.1 \mathrm{~mm}$ long intermixed with hairs $0.5 \mathrm{~mm}$ long, and round sessile glands, the glands round, sessile, orangish to reddish), and costal scales lacking (vs. costal scales present and appressed). This plant may represent a new species, but we refrain from describing it because we have only one specimen.

TAXA CITED FOR ACRE BUT NOT CONFIRMED BY US:

Source: Øllgaard \& Windisch (2016)

Lycopodiella longipes (Hook. \& Grev.) Holub: Marinho 76 (NY), Hoehne 4027, 4028 (R).

Pseudolycopodiella contexta (Mart.) Holub: Monteiro \& Damião 254 (INPA).

Pseudolycopodiella paradoxa (Mart.) Holub: Hoehne 4026 (R).

Source: Almeida \& Salino (2015) 
Cyathea subincisa (Kunze) Domin: A. Salino \& T.E. Almeida 15008 (BHCB).

Cyclodium trianae (Mett.) A.R. Sm.: T.E. Almeida \& A. Salino 2561 (BHCB).

Hypoderris brauniana (H. Karst.) F.G. Wang \& Christenh.: T.E. Almeida \& A. Salino 2578 (BHCB).

\section{Final remarks}

This is the first fern and lycophyte flora published for a state in Amazonian Brazil. For this reason, we cannot compare the number of species in Acre to nearby states. Peru, however, is adjacent to Acre and has a published flora available (Tryon \& Stolze 1989a,b, 1991, 1993, 1994; Smith 1992). Three departments of Peru, near the border of Brazil, share a similar topography and vegetation with Acre, and thus are comparable. These departments are Loreto, Ucayali, and Madre de Díos. Loreto, with an area of $207,000 \mathrm{~km}^{2}$, has 252 species (8 endemics); Ucayali with $106,000 \mathrm{~km}^{2}$, has 105 species (6 endemics), and Madre de Díos with $144,000 \mathrm{~km}^{2}$, has 169 species ( 8 endemics). They are localized on the east flank of the Andes, up to $1,800 \mathrm{~m}$ in a region called by Tryon \& Stolze (1994) as Montaña Ferns. The state of Acre has an area of 153,149 km2, mostly of the terrain belong to lower elevations, varying between 200-580 $\mathrm{m}$, and because this, has smaller diversity (212 species) and no endemic species. This situation is typical for the low elevations in Amazon, as already commented by Tryon \& Tryon (1982).

Prado \& Moran (2009) published a preliminary checklist of the ferns and lycophytes of Acre. The present paper represents the second step, differing from the earlier work by its presentation of taxonomic treatments, illustrations for almost all species, and keys. Despite these two works, Acre almost certainly harbors unrecorded species of ferns and lycophytes. In the coming years, additional species of both groups will be found as more investigations are made. The present paper will help those who are working on this Flora, as well as on other floras in the Brazilian Amazon, since the species treated here occur widely in the region.

\section{Acknowledgments}

This paper is a result of the project Mobilizing Taxonomic Specialists: The State of Acre, founded by Beneficia Foundation. This is a collaborative project between the Federal University of Acre (UFAC) and The New York Botanical Garden (NY). Several specialists were invited to contribute, for ferns and lycophytes. We thank Douglas Daly (NY) and Marcos Silveira (UFAC) for the invitation to participate. We thank John Mitchell, Director of the Beneficia Foundation, for his financial support. Alan Smith (UC) helped with the identification of Steiropteris aff. decussata, Steriopteris sp.1, and improvements to the text in general. Annonymous reviewers for their corrections and suggestions to the MS. The first author thanks $\mathrm{CNPq}$ for providing funds to develop this project (CNPq Proc. ns. 303867/2004-3 and 301157/2010-3), and Daisy Pereira Gomes da Silva, Edilson Consuelo de Oliveira, and José Ribamar Bandeira for help with fieldwork in Acre. The authors also thank Klei Sousa for preparing the illustrations.

\section{Author Contributions}

Jefferson Prado: Substantial contribution in the fieldwork; contribution to the acquisition of data; analysis and interpretation of data; manuscript preparation, and correction of the MS.

Regina Yoshie Hirai: Substantial contribution in analysis and interpretation of data; manuscript preparation, and correction of the MS.

Robbin Craig Moran: Substantial contribution in analysis and interpretation of data; manuscript preparation, and correction of the MS.

\section{Conflicts of interest}

The authors declare that they have no conflict of interest related to the publication of this manuscript.

\section{References}

ALMEIDA, T.E. \& SALINO, A. 2015. Thirteen new records of ferns from Brazil. Biodiversity Data Journal 3: e4421.

ALMEIDA, T.E.; HENNEQUIN, S.; SCHNEIDER, H.; SMITH, A.R.; BATISTA, J.A.N.; RAMALHO, A.J.; PROITE, K. \& SALINO, A. 2016. Towards a phylogenetic generic classification of Thelypteridaceae: Additional sampling suggests alterations of neotropical taxa and further study of paleotropical genera. Molec. Phylogen. Evol. 94: 688-700.

BRITTON, E.G. \& TAYLOR, A. 1902. The life history of Vittaria lineata. Mem. Torrey Bot. Club 8: 185-220.

CÁRDENAS, G.G.; TUOMISTO, H. \& LEHTONEN, S. 2016. Newly discovered diversity in the tropical fern genus Metaxya based on morphology and molecular phylogenetic analyses. Kew Bull. 71: 5-31.

CAVALCANTE, L.M. 2010. Geomorfologia do estado do Acre Pp. 36-46. C.M. DE SOUSA; E.A. DE ARAÚJO; M. DA FONSECA; S.T. MEDEIROS \& A. DE ARAÚJO MAGALHÃES (Orgs.), Livro Temático II: recursos naturais I - Geologia, Geomorfologia e Solos do Acre. ESMA Acre, Rio Branco.

CHRISTENHUSZ, M.J.M; ZHANG, X.-C. \& SCHNEIDER, H. 2011. A linear sequence for extant families and genera of ferns and lycophytes. Phytotaxa 19: 7-54.

EBIHARA, A.; IWATSUKI, K.; ITO, M.; HENNEQUIN, S. \& DUBUISSON, J-Y. 2007. A global molecular phylogeny of the fern genus Trichomanes (Hymenophyllaceae) with special reference to stem anatomy. Bot. J. Linn. Soc. 155: 1-27.

GONZALES, R.J. \& KESSLER, M. 2011. A synopsis of the neotropical species of Sticherus (Gleicheniaceae) with descriptions of nine new species. Phytotaxa 31: 1-54.

JERMY, A.C. 1990. Selaginellaceae. In: KRAMER, K.U. \& GREEN, P.S. (Eds), Pteridophytes and Gymnosperms Vol. I. In: KUBITZKI, K. (Ed.), The Families and Genera of Vascular Plants. Springer-Verlag, Berlin, 39-45. doi: 10.1007/9783-662-02604-5_11.

LABIAK, P.H.; SUNDUE, M.; ROUHAN, G.; HANKS, J.G.; MICKEL, J.T. \& MORAN, R.C. 2014a. Phylogeny and historical biogeography of the lastreopsid ferns (Dryopteridaceae). Amer. J. Bot. 101: 1207-1228.

LABIAK, P.H.; M. SUNDUE; G. ROUHAN \& R.C. MORAN. 2014b. New combinations in Lastreopsis and Parapolystichum (Dryopteridaceae). Brittonia 66: 79-86.

LABIAK P.H.; MICKEL, J.T. \& HANKS, J.G. 2015. Molecular phylogeny and character evolution of Anemiaceae (Schizaeales). Taxon 64: 1141-1158. doi. org/10.12705/646.3

LEHNERT, M. 2016. A synopsis of the exindusiate species of Cyathea (CyatheaceaePolypodiopsida) with bipinnate-pinnatifid or more complex fronds, with a revision of the C. lasiosora complex. Phytotaxa 243: 1-53.

MICKEL, J.T. 2016. Anemia (Anemiaceae), Flora Neotropica Monograph, no. 118 The New York Botanical Garden, New York.

MICKEL, J.T. \& SMITH, A.R. 2004. The pteridophytes of Mexico. Mem. New York Bot. Gard. 88: 1-1055.

MICKEL, J.T.; SMITH, A.R. \& VALDESPINO, I.A. 2004. Selaginella. In: MICKEL, J.T. \& SMITH, A.R. The Pteridophytes of Mexico. Mem. New York Bot. Gard. 88: 550-602.

MORAN, R.C. 1987. Monograph of the neotropical fern genus Polybotrya (Dryopteridaceae). Bull. Ill. Nat. Hist. Surv. 34: 1-138.

MORAN, R.C. 2000. Monograph of the neotropical species of Lomariopsis (Lomariopsidaceae). Brittonia 52: 55-111.

MORAN, R. C.; LABIAK, P.H. \& SUNDUE, M. 2010a. Phylogeny and character evolution in bolbitidoid ferns (Dryopteridaceae). Int. J. Pl. Sci. 171: 547-559. 
MORAN R. C.; LABIAK, P.H. \& SUNDUE, M. 2010b. Synopsis of Mickelia, a newly recognized genus of bolbitidoid ferns (Dryopteridaceae). Brittonia 62: 337-356

MURAKAMI, N. \& MORAN, R.C. 1993. Monograph of the neotropical species of Asplenium sect. Hymenasplenium (Aspleniaceae). Ann. Missouri Bot. Gard. 80: 1-38.

MYNSSEN, C.M.; VASCO, A.; MORAN, R.C.; SYLVESTRE, L.S. \& ROUHAN, G. 2016. Desmophlebiaceae and Desmophlebium: A new family and genus of Eupolypod II ferns. Taxon 65: 19-34.

NITTA, J. \& EPPS, M.J. 2009. Hemi-epiphytism in Vandenboschia collariata (Hymenophyllaceae). Brittonia 61: 392-397.

ØLLGAARD, B. \& WINDISCH, P.G. 2016. Lycopodiaceae in Brazil: Conspectus of the family II. The genera Lycopodiella, Palhinhaea, and Pseudolycopodiella. Rodriguésia 67: 691-719.

PICHI SERMOLLI, R.E.G. 1996. Authors of scientific names in Pteridophyta. Royal Botanic Gardens, Kew.

PPG I 2016. A community-derived classification for extant lycophytes and ferns. J. Syst. \& Evol. 54: 563-603.

PRADO, D.E. \& GIBBS, P.E. 1993. Patterns of species distribution in dry seasonal forest of South America. Ann. Missouri Bot. Gard. 80: 902-927.

PRADO, J. \& LELLINGER, D.B. 2002. Adiantum argutum, an unrecognized species of the A. latifolium group. Amer. Fern J. 92: 23-29.

PRADO, J. \& MORAN, R.C. 2008. Revision of the neotropical species of Triplophyllum (Tectariaceae). Brittonia 60: 103-130.

PRADO, J. \& MORAN, R.C. 2009. Checklist of the ferns and lycophytes of Acre State, Brazil. Fern Gaz. 18: 230-263.

PRADO, J. \& WINDISCH, P.G. 2000. The genus Pteris L. (Pteridaceae) in Brazil. Bol. Inst. Bot. 13: 103-199.

PRADO, J.; HIRAI, R.Y. \& SMITH, A.R. 2014. Dryopteris huberi (Dryopteridaceae), an overlooked species, and a key for the species of Dryopteris in Brazil. Brittonia 66: 340-346.

PRADO, J.; SYLVESTRE, L.S.; LABIAK, P.H.; WINDISCH, P.G.; SALINO, A.; BARROS, I.C.L.; HIRAI, R.Y.; ALMEIDA, T.E.; SANTIAGO, A.C.P.; KIELING-RUBIO, M.A.; PEREIRA, A.F.N.; ØLLGAARD, B.; RAMOS, C.G.V.; MICKEL, J.T.; DITTRICH, V.A.O.; MYNSSEN C.M.; SCHWARTSBURD, P.B.; CONDACK, J.P.S.; PEREIRA, J.B.S. \& MATOS, F.B. 2015. Diversity of ferns and lycophytes in Brazil. Rodriguésia 66: 1073-1083.

PRICE, M.G. 1983. Pecluma, a new fern genus. Amer. Fern J. 73: 109-116.

PRYER, K.M.; HUIET, L.; LI, F.-W.; ROTHFELS, C.J. \& SCHUETTPELZ, E. 2016. Maidenhair ferns, Adiantum, are indeed monophyletic and sister to shoestring ferns, vittarioids (Pteridaceae). Syst. Bot. 41: 17-23.

SALINO, A.; ALMEIDA, T.E.; SMITH, A.R.; GÓMEZ, A.N.; KREIER, H.-P. \& SCHNEIDER, H. 2008. A new species of Microgramma (Polypodiaceae) from Brazil and re-circumscription of the genus based on phylogenetic evidence. Syst. Bot. 33: 630-635.

SCHNEIDER, H.; SMITH, A.R.; CRANFILL, R.; HILDEBRAND, T.J.; HAUFLER, C.H. \& RANKER, T.A. 2004. Unraveling the phylogeny of polygrammoid ferns (Polypodiaceae and Grammitidaceae): exploring aspects of the diversification of epiphytic plants. Molec. Phylogen. Evol. 31: 1041-1063.

SCHUETTPELZ, E.; CHEN, C-W.; KESSLER, M.; PINSON, J.B.; JOHNSON, G.; DAVILA, A.; COCHRAN, A.T.; HUIET, L. \& PRYER, K.M. 2016. A revised generic classification of vittarioid ferns (Pteridaceae) based on molecular, micromorphological, and geographic data. Taxon 65: 708-722.

SCHUETTPELZ, E.; SCHNEIDER, H.; HUIET, L.; WINDHAM, M.D. \& PRYER, K.M. 2007. A molecular phylogeny of the fern family Pteridaceae: Assessing overall relationships and the affinities of previously unsampled genera. Molec. Phylogen. Evol. 44: 1172-1185.

SILVEIRA, M. 2003. Estudos botânicos no Acre: história, resultados e impactos nas políticas públicas. Pp. 209-212. In: JARDIM, M.A.G., BASTOS, M.N.C. \& SANTOS, J.U.M. (Eds.), Desafios da Botânica brasileira no novo milênio: inventário, sistematização e conservação da diversidade vegetal. SBB, UFPA, MPEG, EMBRAPA, Belém.

SMITH, A.R. 1980. Taxonomy of Steiropteris subgenus Steiropteris, including Glaphyropteris (Pteridophyta). Univ. Calif. Publ. Bot 76: 1-38.

SMITH, A.R. 1986. Revision of the neotropical fern genus Cyclodium. Amer. Fern J. 76: 56-98.

SMITH, A.R. 1992. Theypteridaceae. In: TRYON, R.M. \& STOLZE, R.G. (Ed.), Pteridophyta of Peru, Part III. Fieldiana, Bot., n.s., 29: 1-80.

SMITH, A.R.; KREIER, H.-P.; HAUFLER, C.H.; RANKER, T.A. \& SCHNEIDER, H. 2006. Serpocaulon (Polypodiaceae), a new genus segregated from Polypodium. Taxon 55: 919-930.

TRYON, R.M. \& TRYON, A.F. 1982. Ferns and Allied Plants, with Special Reference to Tropical America. Springer-Verlag, New York.

TRYON, R.M. \& STOLZE, R.G. 1989a. Pteridophyta of Peru, Part 1, 1. Ophioglossaceae-12. Cyatheaceae. Fieldiana, Bot., n. s. 20: iii + 1-145.

TRYON, R.M. \& STOLZE, R.G. 1989b. Pteridophyta of Peru, Part II, 13. Pteridaceae-15. Dennstaedtiaceae. Fieldiana, Bot. n. s. 22: iii + 1-128.

TRYON, R.M. \& STOLZE, R.G. 1991. Pteridophyta of Peru, Part IV, 17. Dryopteridaceae. Fieldiana, Bot., n. s. 27: iii + 1-176.

TRYON, R.M. \& STOLZE, R.G. 1993. Pteridophyta of Peru, Part V, 18. Aspleniaceae-21. Polypodiaceae. Fieldiana, Bot., n. s. 27: iii + 1-176.

TRYON, R.M. \& STOLZE, R.G. 1994. Pteridophyta of Peru, Part VI, 22. Marsileaceae-28. Isoetaceae. Fieldiana, Bot., n. s. 32: iii + 1-190.

VALDESPINO, I.A. 1993. Selaginellaceae. Pp.38-63. In: Flora of North America Editorial Committee (Eds.) Flora of North America North of Mexico. Vol. 2. Pteridophytes and Gymnosperms. Oxford University Press, New York.

VALDESPINO, I.A. 2015a. Selaginella boomii (Selaginellaceae - Lycopodiophyta): A new and widely distributed spikemoss from South America. Brittonia. 67: $328-335$.

VALDESPINO, I.A. 2015b. Novelties in Selaginella (Selaginellaceae-Lycopodiophyta), with emphasis on Brazilian species. PhytoKeys 57: 93-133. doi: 10.3897/ phytokeys.57.6489

VALDESPINO, I.A.; HERINGER, G.; SALINO, A.; GÓES-NETO, L.A.A. \& CEBALLOS, J. 2015. Seven new species of Selaginella subg. Stachygynandrum (Selaginellaceae) from Brazil and new synonyms for the genus. PhytoKeys 50 : 61-99. doi: 10.3897/phytokeys.50.4873

ZHANG, L.-B. \& ZHANG, L. 2015. Didymochlaenaceae: A new fern family of eupolypods I (Polypodiales). Taxon 64: 27-38.

ZHANG, L.; SCHUETTPELZ, E.; ROTHFELS, C.J.; ZHOU, X-M.; GAO, X-F. \& ZHANG, L-B. 2016. Circumscription and phylogeny of the fern family Tectariaceae based on plastid and nuclear markers, with the description of two new genera: Draconopteris and Malaifilix (Tectariacae). Taxon 65: 723-738.

WINDISCH, P.G. 1979. Adições ao inventário das pteridófitas do Acre. Bradea 8: $29-30$. 